ESCOLA SUPERIOR DE TECNOLOGIA I CIĖNCIES EXPERIMENTALS DEPARTAMENT DE CIÈNCIES AGRÀRIES I DEL MEDI NATURAL

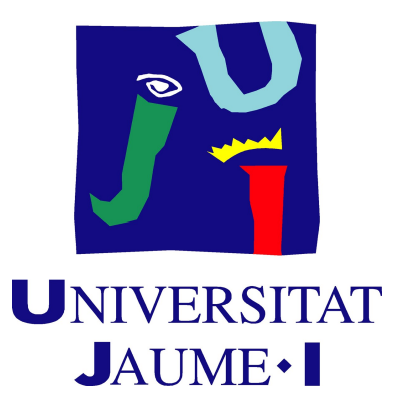

\title{
Redox homeostasis, callose and hormonal responses in primed defenses
}

\author{
Tesis
}

Presentada por:

$M^{a}$ Victoria Pastor Fuentes

Dirigida por:

Victor Flors Herrero

Pilar García-Agustín 

ESCOLA SUPERIOR DE TECNOLOGIA I CIÈNCIES EXPERIMENTALS DEPARTAMENT DE CIÈNCIES AGRÀRIES I DEL MEDI NATURAL

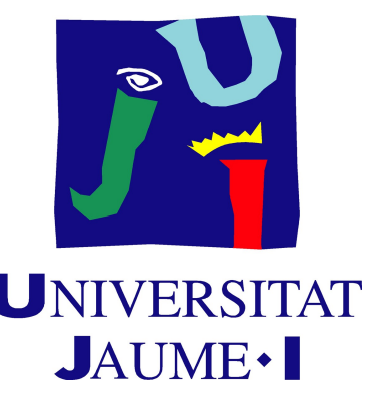

\section{Redox homeostasis, callose and hormonal responses in primed defenses}

\section{PhD Thesis}

$\mathrm{M}^{\mathrm{a}}$ Victoria Pastor Fuentes

Supervisors:

Victor Flors Herrero

Pilar García-Agustín 



\section{LOS DIRECTORES DE TESIS:}

Dr. Victor Flors Herrero, Professor Titular del Área de Fisiología Vegetal, y Dra. Pilar García Agustín, Catedrática del Área de Fisiología Vegetal, del Departamento de Ciencias Agrarias y del Medio Natural de la Universidad Jaume I de Castellón.

HACEN CONSTAR QUE:

La presente memoria de Tesis Doctoral, presentada por María Victoria Pastor Fuentes, titulada "Redox homeostasis, callose and hormonal responses in primed defenses" y realizada en el Área de Fisiología Vegetal de la Universitat Jaume I de Castellón, reúne las condiciones necesarias para su defensa, 



\section{Agradecimientos-Acknolegments}

Por fin ha llegado el final de este camino que empecé de forma incierta y que he terminado gracias a todos vosotros. Soy consciente de que nada se puede solo, pero ni los que empiezan ni los que ya han llegado, si es que en esto del aprender se puede "llegar" alguna vez. La duda que surge es a quién poner primero. si pudiera usaría la horizontalidad en los agradecimientos, pues todos me habéis aportado algo a vuestro nivel. Pero como somos humanos limitados necesitamos la secuencia en el tiempo y el espacio para poder entendernos, así es que, allá voy. Pero conste que el orden no influye en la importancia (jquién puede medir un sentimiento?). Vaya esto por delante.

A Victor, mi director, compañero y pañuelo de lágrimas de risas y de nervios. Por su paciencia, su generosidad científica y personal, y por algo que, por encima de todo me ha ayudado en este complicado camino: su incansable entusiasmo por la ciencia. Lo demás, ya lo sabes. Lo que queda ya te lo contaré a la luz de un buen vino. Y a Pilar (García Agustín), la "vice" y directora, por los comienzos, por brindarme la oportunidad de comenzar esta carrera científica. Gracias a los dos.

A los compañeros del laboratorio, sin duda. son los mejores!!! Vivan las Cheetah Girls! Gemma, la meua companya...gracies per tot el que he aprés de tu (es que ho saps tot!), per la teua humanitat. Y cómo no, a Loredana, por el buen ambiente que habéis generado siempre en mi entorno, haciendo del lugar de trabajo un lugar tan estupendo. Y en todo esto gracias Michel, por tu apoyo y tu buen humor. Todo es importante. También a tí Leonor, porque de una manera u 
otra he notado tu apoyo, gracias por hacer las cosas siempre fáciles. Y Bego, gracies per tot el que $m$ 'has ensenyat, encara em recordo de les primeres infeccions de Pseudomonas...quin temps!. Por supuesto a Emma, Eugenio, Jordi, Blas y Jorge, gracias por formar parte de esta aventura. También a Sara, que durante un tiempo fue una ayuda inestimable, gracias de verdad. A Estrella, por su ánimo, que siempre lo enciende todo. Y por supuesto, por la visita a London, gracias por cuidar de mí esos dias (no lo pasamos mal juerdad?). Por supuesto, Jose (mi Jose), María Foo, María Beltrán, Imma, Elena...gracias. Y claro, Cristian en medio de todo esto. Gracias por tu entusiasmo, por la disposición de solucionar...siempre todo tiene solución.

All my gratitude to Jurriaan and Brigitte, thanks for your support and generosity in these two years. It has been a great pleasure to work with both of you. I hope we can continue working together.

Al mio carissimo amico Marco, per tante cose: Adesso guardo JA e famiglia in altro modo...e questa non è cosa da tutti: Grazie per esserci stato negli ultimi momenti, per essermi stato vicino sempre e avermi dato forza nonostante la distanza...

Un pequeño gran guiño a los de los laboratorios de al lado, gracias por vuestro buen humor, por todas las veces que te llamo, María, porque el speed-vacuum pierde aceite, hace ruidos raros, rozan los tubos...en fin, ya sabes. Y en general por el trato de compañera que me habéis dado cada vez que he ido a pedir algo (que ya sabéis que no han sido pocas). Aquí daos todos por incluidos, porque nunca he tenido un mal gesto por vustra parte. Los que estáis y los que habéis estado. 
Pilar y Sergio, nuestros compañeros del invernadero; Elvira, nuestra "secre": gracias, mil gracias por vuestra ayuda, siempre he encontrado apoyo y atención cuando os he pedido algo. Y sé que a veces soy una pesada, jverdad Elvira?.

y cómo no, gracias también a Reinaldo, que de tantos apuros me $y$ nos ha sacado, siempre con una sonrisa, sin prisas ni agobios. Soy consciente de que alguna vez te hemos pillado de camino a otro sitio... pero siempre te has parado. Realmente imprescindible.

Un recuerdo especial si quiero dejar a mis padres, que ya no están, pero que su recuerdo sigue estando en el laboratorio, en la calle, en el día a día...también a mi tío Pepe, que me enseñó la bondad del trabajo bien hecho sin esperar mayor recompensa. A mi hermano Agus, y a mis cuñadas, que de manera indirecta (o realmente directa) habéis contribuido a que este trabajo se realizara, estando cerca de mis niñas. Gracias por las veces que habéis estado con ellas cuando he estado más ocupada. Muchas veces incluso no habéis sido conscientes, pero lo tengo presente, no lo dudéis. Gracias, gracias hasta el infinito.

Y para acabar, a Miguel, qui sempre ha estat al meu costat, recolçant-me en tot alló que em propose, dies y dies aguantant el mal humor de quan tenie tantes coses que fer en menys tres segons $\left(\lim (x \rightarrow \infty)\right.$ paciencia $\left.=-3^{\prime \prime}\right)$. Y por supuesto, a mis niñas (cómo ha pasado el tiempo!!!) que siempre han respetado los "ahora mamá está ocupada, luego". Por vuestra risa, vuestras preguntas sobre mi trabajo...que lo hacian realmente importante. Sin vosotras, y sense el teu suport, Miguel, nada de esto tendría el más mínimo valor. Gracias desde lo profundo del alma. 
Tingues sempre al cor la idea d'Ítaca 


\section{Contents}

Introducción, metodología, resultados 1

Chapter 1: Introduction. Primed plants 9 do not forget

Chapter 2: Callose deposition: a multifaceted plant defence response regulates primed immune responses in Arabidopsis

Chapter 4: ROS functionality regulates priming of secondary defence responses and signalling cross-talk

Concluding remarks

Conclusiones

Publications and communications

related to the present work 

Introducción 


\section{Objetivos de la investigación: Introducción}

En la lucha por la vida, los seres vivos desarrollan estrategias de defensa para su propia supervivencia. En general, las plantas poseen una inmunidad innata que les permite coexistir con un gran número de microorganismos estableciendo una relación de tipo nohuesped para estos patógenos. Estas primeras barreras defensivas, que ya están ahí antes de que haya relación con el patógeno, son las llamadas defensas constitutivas, que pueden ser tanto de naturaleza física (la cutícula, espinas, o tricomas) como química (emisión de sustancias antimicrobianas, (Osbourn, 1996; Kono, 2011 y citas interiores). Además de estas defensas, las plantas también tienen otras inducibles, que contribuyen a establecer una relación de tipo incompatible entre el patógeno y el huésped (Lipka et al., 2005).

Las defensas inducibles están controladas por rutas alternativas o en ocasiones compartidas del sistema inmune de la planta. La respuesta inmune se genera a través del reconocimiento por parte de la planta de los llamados patrones moleculares asociados a patógenos (PAMPs), o también llamados, en un concepto más amplio, patrones moleculares asociados al microbios (MAMPs) (Bittel and Robatzek, 2007). Algunos de estos PAMPs/MAMPs son compuestos de diversa naturaleza como la proteína flagelina, lipopolisacáridos, glicoproteínas y quitinas, que son reconocidos por receptores transmembrana (PRR) o citoplasmáticos dando lugar a una respuesta defensiva que impide la colonización por parte del patógeno, y comprende la activación de proteínas kinasas (MAPK), generación de especies reactivas de oxígeno (ROS), engrosamiento de la pared celular mediante la deposición de calosa, síntesis de proteínas de defensa R (PR), y la activación transcripcional de genes de defensa. Esta primera línea de defensa impide la penetración del patógeno en el tejido del huésped. Los genes PEN (PENETRATION) se encontraron en una búsqueda de mutantes que mostraran poca resistencia a la entrada del hongo Blumeria graminis f. sp. bordei en una planta no-huésped, Arabidopsis. Se encontraron tres genes PEN1, PEN2 y PEN3 que codifican una proteína sintaxina, una glicosil hidrolasa y un transportador $\mathrm{ABC}$, respectivamente, y está descrito que forman parte del reforzamiento de la pared celular y de la secreción de compuestos antimicrobianos (Zimmerli 2004; Lipka et al 2005; Stein et al., 2006). Frente a bacterias, el cierre estomático también constituye un mecanismo de defensa pre-invasivo (Melotto et al., 2006). Sin embargo algunos de estos patógenos han desarrollado la capacidad de superar este tipo de inmunidad, mediante moléculas efectoras que pueden interferir en la señalización defensiva controlada por la inmunidad innata de la planta y pueden llegar a colonizar la planta. En este caso, el patógeno se enfrentaría a una segunda línea de defensa que requiere la acumulación de compuestos con actividad antimicrobiana, tales como las proteínas PR y fitoalexinas. En el desarrollo co-evolutivo planta-patógeno los nuevos genes de resistencia $R$ aparecerían como respuesta a nuevas proteínas efectoras de los patógenos (Jones and Dangl, 2006).

Además de las respuestas de defensa local, la planta ha desarrollado otros mecanismos sistémicos de defensa, en los que la planta "aprende" a defenderse mediante una sensibilización de los mecanismos defensivos. Esto ocurre tras el ataque de un patógeno 
necrotizante (resistencia sistémica adquirida, SAR), la colonización de la raíces por algunas cepas de rizobacterias no patógenas (respuesta sistémica inducida, ISR), interacciones con micorrizas o mediante el tratamiento con sustancias químicas (Pieterse et al 2000; Oostendorp et al., 2001; Durrant and Dong, 2004, Pozo et al., 2008). Estas respuestas sistémicas están bajo el control de una red de transducción de señales en las que hormonas como el ácido salicílico (SA), ácido jasmónico (JA), ácido abscísico (ABA) y etileno (ET) juegan un papel central. El acondicionamiento previo de las defensas de la planta, es lo que se conoce como priming. Este mecanismo de respuesta permite una respuesta más rápida y más intensa de los mecanismos de defensa por parte de la planta frente a un ataque potencialmente patogénico (Conrath et al., 2006). Las respuestas basales a veces no son suficientes para poder detener el avance del patógeno, pero estimulando de una forma adecuada estas respuestas de defensa basales podemos hacer que la planta reconozca al patógeno y pueda defenderse incluso antes de que el patógeno inicie la supresión de la respuesta inmune (Ahmad et al., 2010). Puesto que la defensa basal está controlada por diversos genes, en lo que se llama una resistencia "horizontal", el acondicionamiento o priming de las defensas basales es eficaz frente a un amplio espectro de patógenos.

En términos generales la presente investigación se enmarca en el estudio de nuevos aspectos fisiológicos y moleculares relacionados con el priming. La producción de ROS y la deposición de calosa son dos de los fenómenos más tempranos de la respuesta basal de la planta tras el reconocimiento del patógeno. Estas dos respuestas están estrechamente relacionadas con el ABA (Ton et al 2009). En general esta hormona ejerce un papel positivo en los primeros momentos de la infección, por ejemplo, estimulando el cierre estomático, mientras que en los últimos estadíos de la infección actúa aumentando la susceptibilidad inhibiendo las respuestas de defensa dependientes de las rutas de SA o del JA (Ton et al., 2009). Sin embargo los resultados sobre la influencia de ABA en la deposición de calosa son contradictorios. Clay et al (2009) demostraron que ABA puede reprimir la acumulación de calosa frente al PAMP flagelina 22 (Flg22) mientras que otros grupos han demostrado que ABA induce la acumulación de calosa en respuesta a infección de distintos hongos y oomycetos (Flors et al., 2005; Asselbergh et al 2008; Ton et al., 2009). Por otro lado, el ABA regula la generación de ROS a través de la proteína kinasa OST1 (OPEN STOMATA 1) que a su vez regula de forma positiva la deposición de calosa a través del factor de transcripción ABI4 (ABSCISIC ACID INSENSITIVE 4) (Ton et al., 2009). Altos niveles de ROS también pueden estimular la síntesis de ABA. En la ruta de síntesis del ABA el paso de violaxantina a zeaxantina requiere la oxidación del ácido ascórbico a dehidroascórbico. El mutante vtcl está bloqueado en la síntesis de ácido ascórbico (Conklin et al., 2000), por lo que tiene mayores cantidades de ROS circulando, y estimula la síntesis de ABA (Pastori et al., 2003). Además, Ton et al. (2004) demostró que el priming de calosa inducido por el compuesto no proteínico ácido $\beta$-aminobutírico frente al hongo necrótrofo Plectosphaerella cucumerina (P. cucumerina) está controlado por la ruta del ABA. No menos controvertido es el papel que juegan las especies reactivas de oxígeno, puesto que tradicionalmente se ha asociado la producción de estas especies reactivas al daño celular. Las principales ROS que se han asociado a papeles señalizadores son el peróxido de hidrógeno $\left(\mathrm{H}_{2} \mathrm{O}_{2}\right)$, el radical superóxido $\left(\mathrm{O}_{2}{ }^{-}\right)$, y el oxígeno singlete $\left({ }^{1} \mathrm{O}_{2}\right)$. Cada vez más se considera que estos compuestos pueden actuar como moléculas señalizadoras intra- e intercelulares (Miller et al., 2009). Algunas de las razones que apoyan esto son, en primer lugar la gran capacidad de generar y detoxificar rápidamente estos compuestos por parte de la maquinaria antioxidante de la célula, permitiendo producir especies reactivas necesarias durante el tiempo necesario. Además, la producción de ROS puede ser local, dentro de un espacio muy concreto de la célula, dando 
lugar al control espacial de la acumulación de ROS, lo que puede hacer muy específica la señalización de eventos posteriores. Por otra parte, estos compuestos pueden salir a los espacios intercelulares, amplificando una señal dada mediante cambios redox y transportándola a largas distancias. $\mathrm{El}_{2} \mathrm{H}_{2}$ puede moverse dentro de la célula e incluso atravesar la membrana plasmática dado que es una especie poco polar y sin carga. Las otras especies oxidantes, aunque no sean neutras, pueden dismutarse o ser enzimáticamente convertidas a $\mathrm{H}_{2} \mathrm{O}_{2}$. Estas espcies reactivas además están íntimamente relacionadas con la red de señalización hormonal así como con la homeostasis celular. Cualquier cambio en los niveles de ROS puede monitorizar el equilibrio del metabolismo celular (Mittler et al., 2011).

(Todas las referencias se encuentran en las referencias de los capítulos siguientes).

\section{OBJETIVOS} estudiar:

Teniendo en cuenta todos estos antecedentes, en este trabajo nos proponemos

a) La interrelación entre $\mathrm{ABA}$, calosa y $\mathrm{H}_{2} \mathrm{O}_{2}$, estudiando cómo influyen las condiciones ambientales en la función del ABA sobre la inducción de calosa, así como el comportamiento estas respuestas frente a PAMPs de distinta naturaleza, uno bacteriano (Flg22) y otro fúngico, (quitosan).

b) El papel que desempeñan las especies reactivas de oxígeno (ROS) en la acumulación inducida por priming de callosa frente a PAMPs (Flg22 y quitosan) y Plectosphaerella cucumerina.

c) Interacciones entre las rutas de defensa reguladas por hormonas y las especies reactivas de oxígeno en priming, frente al patógeno Plectosphaerella cucumerina.

\section{Planteamiento y metodología general}

Para llevar a cabo estos objetivos nos planteamos el siguiente plan de trabajo:

A) Experimentos in vitro.

Se han llevado a cabo experimentos en cultivos in vitro (medio MS, Clay et al., (2009) en plántulas de Arabidopsis de dos semanas desde su siembra, para estudiar los efectos directos de los tratamientos de ABA, BABA, Flg22. Estas condiciones experimentale spermiten un control muy ajustado de parámetros como los niveles de sacarosa o de vitaminas del medio, la luz y a temperatura. El uso de PAMPs nos permite dilucidar de una forma muy directa la relación causa-efecto, en las respuestas de calosa y $\mathrm{H}_{2} \mathrm{O}_{2}$ sin la influencia de toda la maquinaria patógena de los microorganismos. El uso de mutantes que están bloqueados en la producción o detoxificación de peróxido nos permitirá saber qué genes regulan los efectos observados. Por otra parte estudiaremos esos mismos genes en el genotipo control Col-0 para ver la repercusión real que tienen en el sistema molecular de la planta control. 
B) Experimentos planta-patógeno.

Para profundizar en el fenómeno del priming se han llevado a cabo estudios con planta adulta y el hongo $P$. cucumerina. El estudio se ha llevado a cabo realizando un rastreo de resistencia inducida por BABA frente a este patógeno en diferentes mutantes de genes implicados en la homeostasis de especies reactivas de oxígeno y en la regulación hormonal de rutas de defensa. En plantas silvestres del fondo genético Col-0 y en estos mutantes, se han estudiado los fenotipos de resistencia inducida y las respuestas al priming en la acumulación de calosa y $\mathrm{H}_{2} \mathrm{O}_{2}$. Además se han analizado las rutas metabólicas inducidas en priming mediante un estudio genético y metabólico en este sistema planta-patógeno.

Metodología utilizada:

a) Condiciones de cultivo

En los experimentos in vitro plántulas de Arabidopsis Col-0 y mutantes pad2, pen22, vtcl, cat 2 y rbohD fueron sometidas a tratamientos de sacarosa, ABA, BABA, Flg22 y chitosan, en concentraciones según se indican en el apartado de material y métodos de los distintos capítulos. Las semillas se sembraron en medio MS líquido con un $\mathrm{pH}$ final de 5.8 en placas de 12 pocillos estériles. Las semillas crecieron en cabinas de cultivo y se mantuvieron en condiciones de $16 \mathrm{~h}$ de luz, $8 \mathrm{~h}$ de oscuridad, en un ciclo de temperaturas de $20^{\circ} \mathrm{C} /$ día y $17 \%$ noche, en diferentes intensidades de luz, tales que $75 \mu \mathrm{E} \mathrm{m}^{-2} \mathrm{~s}^{-1}$ en experimentos de baja intensidad lumínica y $100-150 \mu \mathrm{E} \mathrm{m}^{-2} \mathrm{~s}^{-1}$ en experimentos de intensidad de luz estándar. A los siete días desde el inico, el medio MS se reemplaza. Los tratamientos de ABA y BABA se hacen al día 8. Los PAMP se aplican al día 9, y el día 10 se recoge la muestra para su análisis.

En los experimentos con planta adulta, la siembra se lleva a cabo en soporte de turba mediante jiffys, transplantando una planta por jiffy. Las plantas se mantienen en cámara de cultivo con un fotoperiodo de $9 \mathrm{~h}$ de luz y $15 \mathrm{~h}$ de oscuridad a $100-150 \mu \mathrm{E} \mathrm{m}^{-2} \mathrm{~s}^{-1}$ de intensidad lumínica, con $65 \%$ de humedad.

\section{b) Bioensayos con P. cucumerina}

Plantas de Arabidopsis de cinco semanas de edad se trataron con $150 \mu \mathrm{M}$ BABA $48 \mathrm{~h}$ antes de la inoculación. A continuación, las plantas se inocularon con una suspensión de esporas de $5 \times 10^{6}$ esporas $/ \mathrm{ml}$ con gotas de $6 \mu \mathrm{l}$ en hojas completamente desarrolladas. Tras la infección plantas se mantuvieron al 100\% de humedad. Se llevó a cabo un muestero a 48 y $72 \mathrm{~h}$ post infección (hpi) para los análisis de hormonas, antioxidantes y expresión génica. El fenotipo de resistencia se determinó al $6^{\circ}$ día después de la inoculación, y se cuantificó mediante el tamaño de necrosis producida por el patógeno, sin tener en cuenta la clorosis que pueda aparecer en algunas infecciones.

\section{c) Microscopía}

La calosa y el $\mathrm{H}_{2} \mathrm{O}_{2}$ detectaron por tinciones de azul de anilina y 3,3'diaminobenzidina respectivamente, y fueron visualizadas en microscopio de epifluorescecia bajo luz UV para la detección de calosa y campo claro para el $\mathrm{H}_{2} \mathrm{O}_{2}$. En ambos casos la cuantificación de la acumulación de calosa y peróxido se hizo mediante el análisis de 
fotografía digital como número de píxeles relativos a la superficie cuantificada mediante el software Photoshop CS2. Las tinciones se realizaron como se describe en Ton et al. (2004) en la caso de la calosa y Bueso et al. (2007) en el caso de $\mathrm{H}_{2} \mathrm{O}_{2}$.

\section{d) RT-qPCR}

Análisis de transcripción de genes se llevaron a cabo mediante la técnica de cuantificación de mRNA tras su conversión a cDNA y amplificación mediante cebadores específicos de los genes estudiados, RBOHD, APX1, GSH1, VTC1, CAT2, PR1, RAB18, $M Y C 2, P D F$ 1.2, VSP2, comparando su expresión con los genes constitutivos GAPDH3 y Atlg13320. Mediante el análisis de la curva de melting se comprobó la pureza del producto amplificado.

d) Análisis de los niveles de hormonas y de glutatión (GSH)

La cuantificación de hormonas se llevó a cabo mediante cromatografía de HPLCMS, según Kravchuck et al. (2011) y Pastor et al (2012) mientras que el análisis de GSH reducido y oxidado se realizó mediante cromatografía de UPLC-MS, según Rellán-Alvarez et al. (2006) con algunas modificaciones, descritas en el capítulo 3.

\section{Aportaciones originales}

\section{Publicaciones:}

Luna E., Pastor V. (both authors, equal contribution), Robert J., Flors V., MauchMani B., Ton J., 2011. "Callose deposition: a multifaceted plant defence response" Mol. Plant Microbe Interact., 24,183-93.

Pastor V., Vicent C., Cerezo M., Mauch.Mani B., Dean J., Flors V., 2012. "Detection, characterization and quantification of salicylic acid conjugates in plant extracts by ESI tandem mass spectrometric techniques". Plant Physiology and Biochemistry, 53, $19-26$.

Pastor V., Luna E. (both authors, equal contribution), Mauch-Mani B., Ton J., Flors V., 2012. "Primed plants do not forget". Environ. Exp. Bot., doi:10.1016/j.envexpbot.2012.02.013.

Pastor V., Luna E., Cerezo M., Ton J., García-Agustín P., Flors V., (enviado). "Fine tuning of ROS homeostasis regulates primed immune responses in Arabidopsis".

"Reactive oxygen species functionality regulates priming of secondary defence responses and signallingcross-talk" (en preparación).

Pastor V, Luna E, Ton J, García-Agustín P, Cerezo M, Flors V: "Hydrogen peroxide mediates callose priming induced by BABA upon chitosan treatment". XIX Reunión de la Sociedad Española de Fisiología Vegetal. XII Congreso Hispano Luso. (Castellón, 21-24 
junio 2011). Libro de resúmenes de conferencias plenarias e invitadas, p. 29, S5-P8. ISBN 978-84-8021-805-4.

\section{Proceeding}

Pastor V., Luna E., Ton J., García-Agustín P., Cerezo M., Flors V., 2011. “A specific homeostasis between callose and $\mathrm{H}_{2} \mathrm{O}_{2}$ is needed for an intact BABA-IR against $P$ cucumerina”. IOBC Working Group (en prensa)

\section{Póster en congresos}

Pastor V., Luna E., Ton J, García-Agustín P, Cerezo M, Flors V: "Hydrogen peroxide mediates callose priming induced by BABA upon chitosan treatment." XIX Reunión de la Sociedad Española de Fisiología Vegetal. XII Congreso Hispano Luso. (Castellón, 21-24 junio 2011).

Pastor V, Luna E, Ton J, García-Agustín P, Cerezo M, Flors V: "A specific homeostasis between callose and $\mathrm{H}_{2} \mathrm{O}_{2}$ is needed for an intact BABA-IR against $P$. cucumerina." PR-Proteins and Induced Resistance Against Pathogens and Insects (Neûchatel-Switzerland, 4-8 septiembre 2011).

Pastor V., Luna E., Ton J., Cerezo M., García-Agustín P., Flors V., : "More oxidized environment is needed to develop primed responses against Plectosphaerella cucumerina" Society for Experimental Botany Annual Meeting (Salzburg 29 junio-2 julio 2012). 

CHAPTER 1

\author{
Introduction
}

Primed plants do not forget 


\section{Introduction}

Plants are well equipped to defend themselves against the majority of harmful microbes and insects. For instance, most plants react to attack by producing defensive compounds that are toxic to the attacker. These inducible defences are controlled by plant's innate immune system. In response to attack by pathogenic microbes, innate immune responses are typically triggered by "pathogen-associated molecular patterns" (PAMPs; synonymously called MAMPs for "microbe-associated molecular patterns"). The resulting "PAMP-triggered immunity" (PTI) protects the plant against the majority of potentially harmful micro-organisms. However, a minority of virulent plant pathogens have evolved mechanisms to suppress PTI by employing defence-suppressing effector molecules that deregulate the signalling pathways controlling plant innate immunity (Jones and Dangl, 2006). As a co-evolutionary response, plants have acquired the ability to recognize virulent pathogens at early stages of attack and counter an appropriate defence response. A wellknown example of such co-evolved plant defence is "effector-triggered immunity" (ETI), which enables the plant to recognize the presence or activity of specific pathogen effectors. ETI requires resistance $(R)$ genes in the host plant and can render specific virulent pathogens a-virulent. Although ETI provides full immunity against selected pathovars of biotrophic pathogens, a-virulent strains are under constant selective pressure to evolve new effectors that are no longer recognized or that can suppress ETI. Consequently, disease protection by single $R$ genes is not always sustainable (Boyd, 2006).

\section{Priming of defence: an adaptive plant immune response.}

As an alternative strategy to cope with virulent pathogens, plants have evolved the ability to adapt to the hostile conditions in their environment by sensitizing their immune system in response to hostile signals in their environment. This so-called "priming of defence" results in a faster and stronger induction of basal resistance mechanisms upon subsequent pathogen attack (Conrath et al., 2006; Ahmad et al., 2010; Conrath, 2011). Basal resistance by itself is too weak to protect against virulent pathogens, since it constitutes a residual level of resistance after immune suppression by the pathogen. However, priminginducing stimuli can render basal resistance more effective, particularly when the accelerated defence response precedes immune suppression by the invading pathogen (Ahmad et al., 2010). Priming events, additionally, involve multiple cellular localizations (Fig. 1). Since basal resistance is controlled by a multitude of genes ("horizontal resistance"), priming of basal resistance is effective against a broad range of diseases and may be more sustainable than ETI, which is based on single $R$ genes. We demonstrated previously that priming provides disease resistance with relatively minor reductions in plant fitness, indicating that it is a beneficial survival strategy for plants in relatively hostile environments. Furthermore, the primed defence state can be maintained long after the initial stimulus (Conrath et al., 2006), thereby pointing to a form of plant immunological memory. Thus, priming of defence allows plants to boost their innate immune system and offers a long-term adaptation to disease-conducive conditions. 


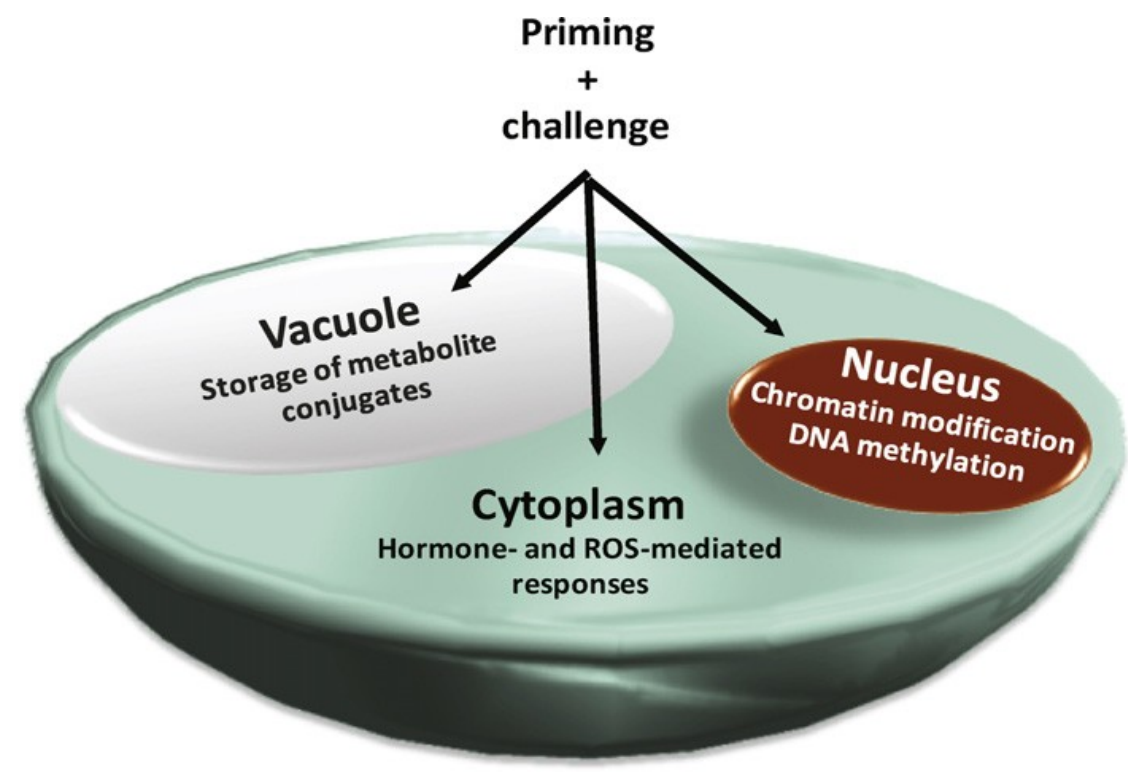

Figure 1. Cellular localization of targets by defence priming. Inactive metabolites are stored in the vacuole, which can be hydrolized and released into the cytoplasm. In the cytoplasm, ROS can interact with SA-, JA- or ABA-dependent pathways. In the nucleus, priming can act through epigenetic mechanisms, such as histone modifications and DNA methylation.

\section{Priming-inducing signals provide broad-spectrum plant protection.}

Defence priming in plants is typically triggered by signals that indicate up-coming attack by pathogens or herbivores. A classic example is "systemic acquired resistance" (SAR), which is triggered by localized pathogen attack and brings about a systemic priming of salicylic acid (SA)-inducible defence mechanisms (Jung et al., 2009; Kohler et al., 2002). This mode of action is consistent with its effectiveness against biotrophic pathogens, which are predominantly resisted by SA-inducible defences. Another well-known example of stress-indicating priming signals are volatile organic compounds (VOCs), which are emitted by herbivore-infested plants. Some VOCs can prime jasmonic acid (JA)-dependent defences in systemic plant parts and neighbouring plants (Turlings and Ton, 2006; Ton et al., 2007; Heil and Ton, 2008). However, not all priming responses are triggered by hostile signals. For instance, priming can be triggered by plant-beneficial organisms, such as nonpathogenic rhizobacteria and mycorrhizal fungi, which results in an "induced systemic resistance" response (Van Wees et al., 2008). ISR-related priming is associated with priming of JA-dependent defences (Verhagen et al., 2004; Pozo et al., 2008; Van der Ent et al., 2009) which explains why ISR is mostly effective against pathogens that are resisted by JAinducible defences (Ton et al., 2002). In addition to biological agents, there are various chemicals that can mimic biologically induced priming phenomena. Application of these chemicals delivers a more consistent and less variable priming response, thereby making the phenomenon more accessible for molecular and genetic studies. Many priming-inducing 
chemicals are endogenous plant compounds, or functional analogues thereof, which become synthesised by the plant in response to biotic stress signals, such as SA (Kauss et al., 1995), JA (Frost et al., 2008) and azelaic acid (Jung et al., 2009). An obvious exception to this rule is beta-aminobutyric acid (BABA), which is a plant xenobiotic compound. This non-protein amino acid can induce resistance in many different plant species against an exceptionally wide spectrum of (a)biotic stresses. Moreover, BABA is active at relatively low concentrations and acts in an enantiomer-specific manner (Jakab et al., 2001; Cohen, 2002). These characteristics suggest that BABA either mimics an endogenous plant signalling compound, or that it ectopically activates an endogenous signalling compound that regulates multiple immune responses simultaneously. Indeed, it has been demonstrated previously that BABA not only mimics SAR-related priming by potentiating SA-inducible defences, but also primes pathogen-induced deposition of callose-containing papillae, which functions independently of SA and JA, but requires intact biosynthesis and perception of the plant hormone abscisic acid (ABA) (Zimmerli et al., 2000; Ton and Mauch-Mani, 2004; Van der Ent et al., 2009).

\section{Targets of priming: which defences become primed?}

\section{Priming targets early- and late-acting defences.}

Induced plant defence is a complex phenomenon involving multiple defence layers that become active at different stages of attack (Ton et al., 2009; Ahmad et al., 2010). Priming of defence has been described to augment early- and late-acting defence reactions that become active after tissue penetration by a pathogen (Fig. 2). Early acting post-invasive defences are typically triggered by microbe-associated molecular patterns (MAMPs) and are marked by rapid accumulation of reactive oxygen species (ROS), usually followed by depositions of callose-rich papillae (Luna et al., 2011). If an invading pathogen is capable of repressing these relatively early defences, it will face a second layer of relatively late acting defences. This inducible defence layer involves regulation by de novo produced defence hormones, such as SA and JA, and is associated with the generation of long-distance defence signals that can induce resistance in systemic plant parts. Interestingly, the plant hormone ABA plays diverse regulatory roles in both early and late defences. Apart from its function in rapid stomatal closure upon detection of bacterial pathogens (Schulze-Lefert and Robatzek, 2006; Melotto et al., 2008), ABA also enhances the timing and intensity of callose deposition against invading necrotrophic pathogens (Ton and Mauch-Mani, 2004; Flors et al., 2005; Flors et al., 2008; Ton et al., 2009). However, stimulation of ABAdependent responses at later post-invasive stages can result in increased plant susceptibility, due to the negative cross-talk with SA-dependent pathway (Ton et al., 2009). The timeframe in which induced defence against herbivorous insects occurs is often rather different (Frost et al., 2008). Firstly, insect infestation is often associated with major tissue damage, which allows for a very rapid activation of phyto-anticipins (i.e constitutively accumulated substances that are stored in special compartments of a plant cell or in an inactive form), such as glucosinolates and benzoxazinoids. Secondly, herbivore-infested plants synthesize volatiles that can attract natural enemies of the herbivore (Turlings and Ton, 2006). It has been shown recently that stress imposed by UV-irradiation also triggers Me-SA and Me-JA emission, which are perceived by neighbouring plants (Yao et al., 2011). Interestingly, some of these herbivore-induced volatiles have been reported to induce priming in distal plant parts or even neighbouring plants. This resistance-inducing activity of volatiles functions as 
a rapid airborne signal to prime systemic plant parts for the much slower moving vascular defence signals (Heil and Ton, 2008).

\section{Priming targets early defences: abscisic-induced stomatal closure; production of reactive oxygen species and callose accumulation.}

The first contact between a pathogen and the host plant occurs at the leaf surface. In the absence of open wounding sites, bacterial pathogens attempt to penetrate through stomata. To counteract pathogen penetration, plants can perceive PAMP signals, such as flg22 and LPS, that trigger a rapid stomatal closure. This reaction requires intact ABA and SA signalling and is mediated by the kinase OST1 (Melotto et al., 2006). Virulent bacterial pathogens have evolved strategies of effector triggered susceptibility to supress this early pre-invasive defence (Jones and Dangl, 2006). For instance, secretion of coronatine effector by Pseudomonas syringae forces plant stomata to reopen and facilitate bacterial penetration (Schulze-Lefert and Robatzek, 2006). Furthermore, coronatine targets the COII receptor by activating JA-dependent signals that suppress effective plant defences against Pseudomonas syringae $p v$ tomato (Pst). Priming has been demonstrated to target defences acting at these early stages of plant-pathogen interactions. Treatments with the priming agent BABA trigger a faster stomatal closure upon abiotic stress conditions (Jakab et al., 2005). In addition Tsai et al. (2011) demonstrated that BABA suppresses more than 30 genes that are targeted by coronatine. In agreement with this, we have recently demonstrated that the constitutive priming mutant nrt2.1 displays a hypersensitive SA response and accordingly is less responsive to coronatine-mediated suppression of $\mathrm{ABA}$ and stomatal manipulation (Camañes et al., 2012).

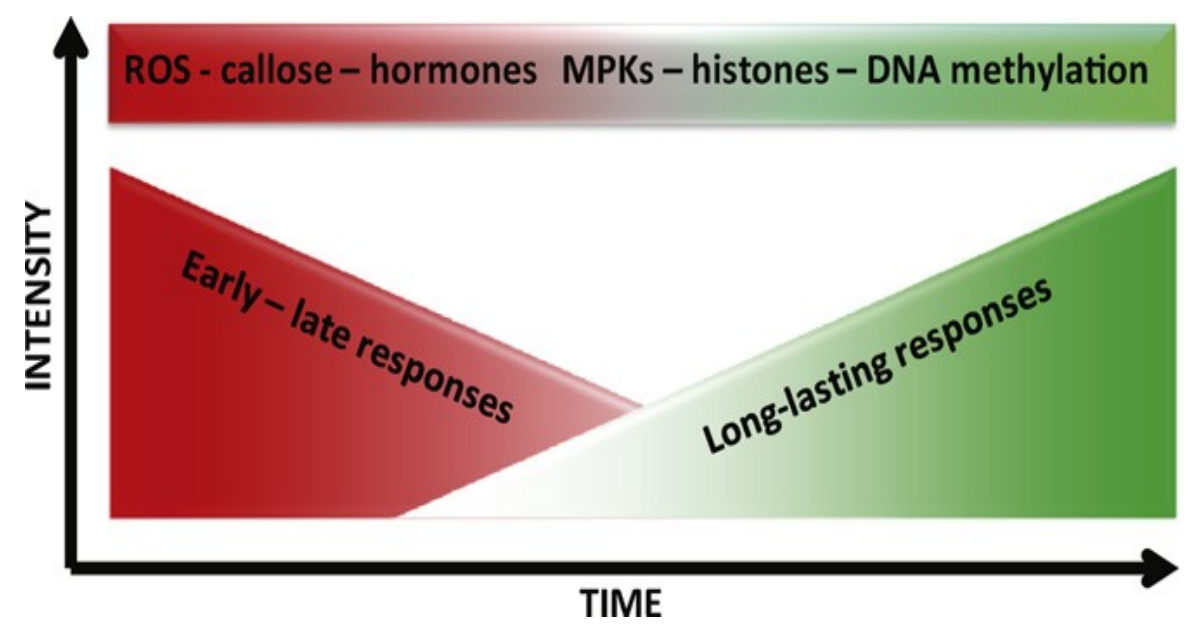

Figure 2. Temporal events during priming. The main mechanisms of priming are temporally dissected. ROS and callose accumulation and hormonal responses happen relatively early after challenge, however, the accumulation of unphosphorylated MPKs, the modification of histones and DNA methylation are long lasting processes that can be transferred to the offspring. Additionally, the intensity of early responses can lose strength some time after challenge, while long term priming events gain relevance and are expressed stronger when the priming signals are maintained in time or repeated in descendants.

ROS signalling consists of a complex network that interacts extensively with hormonal networks, which allows plants to regulate developmental processes and abiotic 
and biotic stress responses. The term "oxidative stress" has been used to define the imbalance between ROS production and detoxification. However, recent studies have changed this terminology to indicate that ROS play a major role in the regulation of cellular processes by acting as signalling molecules (Foyer and Noctor, 2005; Moller et al., 2007). Very recently, Mittler et al. (2011) proposed several mechanisms to explain the role of ROS in cell signalling. They hypothesize that changes in redox homeostasis generate specific ROS signals, which prime neighbouring cells for defence. The so-called ROS wave can be accompanied by other signals, such as hormones and small peptides. In addition, the amplitude, frequency and localization of the ROS signal could entail specific information with respect to the defence response. The signal initiated by ROS is sensed by specific receptors that can transfer the message to activate other networks through phosphorylation cascades (Colcombet and Hirt, 2008) (Fig. 3A).

In the time course of a pathogen attack, ROS mediate the defensive response through oxidative waves that activate signal transduction and the expression of defencerelated genes locally and systemically (Shetty et al., 2008). The occurrence of a second oxidative wave prepares the plant to mount a more efficient defence against pathogens. Unger et al. (2005) showed that avirulent isolates of Botrytis cinerea trigger an intense second $\mathrm{O}_{2}^{-}$burst in bean suspension cells that is absent in the interaction with virulent strains. Moreover, infections with avirulent bacteria in tobacco result in an AMINO CYCLOPROPANE CARBOXILIC ACID SYNTHASE (ACS)-mediated secondary accumulation of ethylene (ET), $\mathrm{H}_{2} \mathrm{O}_{2}$ and SA. In this particular plant-pathogen interaction, there is a coordinated transient first wave of $\mathrm{H}_{2} \mathrm{O}_{2}$ and nitric oxide (NO), which leads on to a stronger increase of SA resulting in the onset of the SAR response (Mur et al., 2008, 2009).

Years ago, Baker and Orlandi (1995) demonstrated that only the second burst can stop pathogen invasion. Thus, it is likely that during incompatible interactions, plants prime themselves for a stronger response against the invading pathogen. Indeed, positive interactions between ROS and indole acetic acid (IAA) take place during programmed cell death in response to biotic stress. Truman et al. (2010) suggested a model in which upon pathogen recognition, a first peak of JA is necessary for induction of IAA, flavonoids, indole glucosinolates and camalexin. Several genes involved in biosynthesis and homeostasis of IAA are altered during establishment of SAR (Zhang et al., 2007; Truman et al., 2010). Specifically, prior to the transient expression of the SA-dependent pathway, localized pathogen infections induce a gene encoding auxin-conjugating enzymes (GH3) and consequently the pool of free IAA is reduced (Ding et al., 2008; Truman et al., 2010).

The role of ROS homeostasis in priming has recently been demonstrated. Phenotypic analysis of the ascorbic acid-deficient vtcl mutant suggested that the enhanced resistance of this mutant to $P$. syringae is associated with an augmented capacity for accumulation of $\mathrm{H}_{2} \mathrm{O}_{2}$, SA and $P R$ gene transcripts (Mukherjee et al., 2010). Furthermore, thiamine (vitamin $\mathrm{B}_{1}$ )-induced resistance against Pst $\mathrm{DC} 3000$ is associated with $\mathrm{H}_{2} \mathrm{O}_{2}$ dependent priming of defence genes (NPR1, PRI and PALl) and callose deposition (Ahn et al., 2007). Another vitamin, riboflavin (vitamin $\mathrm{B}_{2}$ ), primes resistance against different pathogens. Zhang et al. (2009) demonstrated that vitamin $\mathrm{B}_{2}$-induced resistance against Pst DC3000 is associated with priming of $\mathrm{H}_{2} \mathrm{O}_{2}$ production, callose deposition and SA-inducible marker genes. Defence priming by this vitamin during other plant-pathogen interactions is also associated with an augmented accumulation of $\mathrm{H}_{2} \mathrm{O}_{2}$ (Taheri and Tarighi 2010, 2011). The flavonoid compound quercetin has also been described to induce resistance against $P$. 
syringae by increasing $\mathrm{H}_{2} \mathrm{O}_{2}$ and callose production, which is associated with priming of $P R 1$ and PAL gene expression and requires an intact SA- and NPR1-dependent signalling pathway (Jia et al., 2010).

Primed ROS production may start during the initial stages of contact between the pathogen and the cell, causing a stimulation of cell membrane proteins that can produce peroxides. This is for instance the case in grape, where BABA-induced priming targets ROS production and $R B O H D$ expression transcripts upon oligogalacturonide (OG) PAMP stimulation. This enhanced activity of the ROS pathway results in a NADPH oxidasedependent increase in resistance against the oomycete Plasmopara viticola (DubreuilMaurizi et al., 2010). Moreover, Baysal et al. (2007) demonstrated in tomato that a synergistic effect in disease resistance against $P$. syringae can be achieved by exposing seedlings simultaneously to salt stress and BABA. Importantly, they demonstrated that this priming is mediated by an increase of the antioxidant enzymatic machinery and $\mathrm{H}_{2} \mathrm{O}_{2}$ production (Baysal et al., 2007). However, in some particular interactions, bacterial effectors can trigger a ROS burst that results in the collapse of the plant's antioxidant system. Concomitantly, the priming mutant $n r t 2.1$ is affected in the activation of a diseaseassociated redox burst, suggesting that the NRT2.1 gene may be a target for the coronatineinduced $\mathrm{H}_{2} \mathrm{O}_{2}$ burst (Camañes et al., 2012).

Accumulation of ROS in response to stresses initiates cascades of kinases in a direct or OXI1- NDPK2- or MPK3/MPK6-dependent manner (Colcombet and Hirt, 2008). Interestingly, MPK3 and MPK6 are required for full priming of stress responses in Arabidopsis (Beckers et al., 2009). The role of MAP kinases in priming is discussed below. In addition to MPKs, ROS can directly activate transcription factors (TF) or signalling proteins. Moreover, TF and ROS-responsive elements interact in a positive loop where TFs activate ROS-dependent genes (Desikan et al., 2001; Neill et al., 2002, Laloi et al., 2004; Mittler et al., 2004).

PAMP-induced ROS accumulation is often immediately followed by deposition of callose (Clay et al 2009; Luna et al 2011). Priming of callose by chemicals, such as BABA or hexanoic acid, results in enhanced resistance against necrotrophic and biotrophic pathogens (Ton and Mauch-Mani, 2004; Flors et al., 2008; Vicedo et al., 2009). The signalling pathways underlying BABA and hexanoic acid-induced priming of callose require intact $\mathrm{ABA}$ signalling in Arabidopsis and tomato, respectively. Furthermore, both Arabidopsis and tomato respond remarkably similarly to BABA and ABA in terms of callose priming (Ton and Mauch-Mani 2004; Flors et al., 2008; Vicedo et al 2009). A possible link between ABA signalling, ROS homeostasis and callose deposition has been proposed on the basis of the Arabidopsis zeaxantine epoxidase (ZEP) mutants abal-5 and ibs3, which are reduced in BABA-induced priming of callose (Ton and Mauch-Mani, 2004; Ton et al., 2005). It is possible that the inability of these ZEP mutants to express an augmented callose response is related to the anti-oxidant properties of zeaxanthin and its interaction with the xanthophyll cycle and ascorbate (Ton et al., 2009). BABA-induced priming of callose is dependent on the PMR4 callose synthase. Interestingly, however, the role of ABA in callose priming is not restricted to this callose synthase, since exogenous treatments with ABA can render other callose synthases in the pmr4-1 mutant responsive to A. brassicicola infection (Flors et al., 2008). Recently, there has been a noticeable rise in contradicting reports about the regulation of pathogen-induced callose (Ton et al., 2009; Luna et al., 2011). To address this controversy, we examined the robustness of PAMPinduced callose deposition under different growth conditions (Luna et al., 2011). Based on a 
commonly used hydroponic culture system, it was found that subtle variations in growth conditions have major impacts on the intensity of callose deposition, which correlated with levels of hydrogen peroxide $\left(\mathrm{H}_{2} \mathrm{O}_{2}\right)$ production. Most striking was the effect of ABA on PAMP-induced callose, which varied from repressive to stimulatory, depending on the growth conditions. Hence, the interplay between ROS, ABA and callose is controlled by distinct signalling mechanisms that vary according to the environmental conditions that plants are exposed to.

\section{Priming of relatively late-acting defences: hormone-controlled priming}

A single priming-inducing treatment can sensitize multiple defence responses. This broad range of effectiveness can partially be explained by the fact that priming treatments can target response pathways of central regulatory hormones of plant defence, such as JA and SA (Conrath et al., 2006; Conrath, 2011). Such priming of JA- and SA-dependent defence mechanisms is often based on a sensitization of the tissue to these hormones (Pieterse et al., 1998; Durran and Dong, 2004; Ton et al., 2005; Flors et al., 2008; Pozo et al., 2008). Well-known examples of priming of the JA pathway come from rhizobacteriaand mycorrhiza-induced systemic resistance (ISR), which is associated with a systemic priming of JA-dependent defences (Van Wees et al. 2008). Defence priming by herbivoreinduced volatiles from neighbouring plants can also target a subset of JA-dependent defences (Ton et al., 2007). On the other hand, pathogen-induced SAR is predominantly associated with priming of SA-dependent defences (Jung et al., 2009; Conrath, 2011). Evidence is emerging that priming of hormone-controlled defences requires a coordinated change in the equilibrium between different hormone-dependent pathways. As discussed below, this can manifest itself as a shift in the antagonistic cross-talk balance between SA and JA (Pieterse et al., 2009).

The plant hormone ABA has also been implicated in defence priming (Mauch-Mani and Mauch, 2005; Flors et al., 2009) (Fig. 3A). This function of ABA is complex and does not solely rely on sensitization of the tissue to ABA, but also depends on the interaction between the ABA response pathway and other defence signalling pathways (Flors et al., 2009). For instance, the protein kinase EDR1 has been reported to act as a negative regulator of both SA- and ABA-dependent plant responses. As a consequence, the edr1-1 mutant displays constitutive priming of the SA-inducible PRI gene, but at the same time displays hypersensitivity to ABA and an increased capacity to deposit callose (van Hulten et al., 2006). A genetic suppressor screen for mutations blocking edrl-dependent resistance led to the identification of the keg-4 mutant, which represses ABA responsiveness by targeting the ABI5 transcription factor for degradation. The gain-of-function keg-4 mutation boosts ubiquitin ligase activity by KEG, thereby allowing lower ABI5 levels and reduced ABA sensitivity (Warzynska et al., 2008). Hence, the phenotype of the edrl-1 mutant links ABA hypersensitivity to priming of multiple SA-dependent and -independent defences (reviewed in Mauch-Mani and Flors, 2009), but act as a suppressor of ABA synthesis when Arabidopsis is attacked by the non-host fungus $B$. graminis.

The callose accumulation is an early response that is in part regulated by the homeodomain transcription factor $O C P 3$. Callose deposition is under negative control by OCP3, therefore the ocp 3 mutant is primed for callose deposition and more resistant to necrotrophic pathogens. The enhanced callose deposition of this mutant requires intact JA 
and ABA signalling. Hence, the interplay between $\mathrm{JA}$ and $\mathrm{ABA}$ is important for the establishment of a primed callose response in ocp3 (García-Andrade et al., 2011). Healthy ocp 3 plants showed increased production of $\mathrm{H}_{2} \mathrm{O}_{2}$ and higher basal levels of $\mathrm{ABA}$, which is probably the reason for its primed callose response. A fine tuning between SA, ABA and JA has been reported as a putative mechanism of defence priming. For instance, the nrt-2.1 mutant is primed via two independent mechanisms. This mutant displays constitutive priming of SA-dependent gene expression, but is also altered in ABA-related responses such as stomatal closure and hydrogen peroxide accumulation. A plausible explanation for this mutant phenotype is that NRT2.1 disruption confers reduced sensitivity to the bacterial effector coronatine (Camañes et al., 2012). Accordingly, Tsai et al. (2011) demonstrated that BABA-induced resistance (BABA-IR) against $P$. syringae partially relies on suppression of coronatine-induced genes. Finally, crosstalk between ABA and other signalling pathways can involve defence regulatory proteins, such as MYC2 (Fujita et al., 2006) and Mitogenactivated protein kinases (MPKs). For example, MPK5 regulates the convergence between ABA and ET (de Vleesschauwer et al., 2010). During infection of rice by Cochliobolus miyabeanus, ABA can enhance resistance by MKP5-dependent suppression of pathogeninduced ET emission.

\section{Mechanisms of priming}

Most studies on priming described above have focussed on the identification of priming-eliciting stimuli, its defensive targets, and its effectiveness in terms of induced resistance (Conrath et al., 2006). By contrast, much fewer studies have attempted to elucidate the molecular and cellular mechanisms underpinning defence priming (Conrath, 2011). In this review, we describe priming as a component of induced resistance and the possible mechanisms underlying this defence phenomenon.

\section{conjugates \\ Priming through enhanced accumulation of inactive defence metabolite-}

As mentioned above, one of the prominent features of primed plants is a rapid induction of callose-containing papillae upon challenge with microbial pathogens (Ton and Mauch-Mani, 2004, Flors et al., 2008). In this context, recent discoveries that indole-derived phyto-anticipins regulate a timely deposition of callose may be relevant (Bednarek et al., 2009; Clay et al., 2009; Ahmad et al., 2010). Phyto-anticipins, such as glucosinolates in brassicaceous plant species and benzoxazinoids in cereals, have traditionally been associated with defence against chewing insects, since it was assumed that cellular disruption is necessary to bring the glucosylated metabolite from the vacuole into contact with the hydrolytic $\beta$-glucosidases that are stored in different cellular compartments (Morant et al., 2008). These $\beta$-glucosidases display high levels of identity at the amino acid sequence level and a similar tertiary structure (Barrett et al., 1995; Verdoucq et al., 2004). Glucosinolates are hydrolyzed by S- $\beta$-glucosidases (Lenman et al., 1993; Barth and Jander, 2006), whereas the glucosylated benzoxazinoids DIBOA (2,4-dihydroxy-1,4-benzoxazin-3one) and DIMBOA (2,4-dihydroxy-7-methoxy-1,4-benzoxazin-3-one) are hydrolysed by O$\beta$-glucosidases (von Rad et al., 2001) (Fig. 3 B).

In Arabidopsis, early-acting cell wall-associated resistance against non-host powdery mildew is mediated by the synthesis of the indole glucosinolate (IGS) 4- 
methoxyindol-3-ylmethylglucosinolate (4MI3G) and subsequent hydrolysis by the atypical myrosinase PEN2 (Bednarek et al., 2009). Interestingly, treatments with the bacterial elicitor Flg22 trigger callose deposition in an IGS- and PEN2-dependent manner (Clay et al., 2009). Therefore, priming of callose deposition could be achieved by boosting endogenous accumulation of $4 \mathrm{MI} 3 \mathrm{G}$ that is ready to be hydrolyzed by PEN2 upon subsequent pathogen attack. In maize, a similar role has been attributed to the benzoxazinoid compound DIMBOA. Benzoxazinoid-deficient maize genotypes were found to be affected in chitosaninduced callose, while aploplastic infiltration with DIMBOA caused an increased deposition of callose (Ahmad et al., 2011). Similarly as for 4MI3G in Arabidopsis, an increased pool of DIMBOA-glc could contribute to priming of callose deposition. Interestingly, Frebortova et al., 2010 demonstrated that DIMBOA is associated with the degradation of cytokinins. Oxidation of DIMBOA leads to the generation of free radicals that are used as a substrate by cytokinin dehydrogenases (Frebortova et al., 2010). The discovery that hydrolysed breakdown products of glycosinolates and benzoxazinoids regulate callose deposition suggests yet unknown cellular processes to deliver the chemical defence compounds into the apoplast. However, it seems plausible that an increased pool of indole-derived phytoanticipins can contribute to priming of callose deposition.

Priming by glucosylated secondary metabolites is a mechanism that can also be applied to plant hormone-glucosides. For instance, the physiologically inactive ABAglucose-ester (ABA-GE) is an extremely hydrophilic conjugate that easily moves along the xylem. Dietz et al. (2000) described that the ABA-GE concentration rises dramatically under stress conditions. Glucosylated and methylated ABA-conjugates accumulate mainly in the vacuoles (Kaiser et al., 1985) and free ABA can be released through the action of apoplastic esterases (Sauter et al., 2002). The activities of esterase and $\beta$-glucosidases have been shown to increase when barley plants were subjected to salt stress (Dietz et al., 2000). Hence, priming against biotic stress could also be based on an increased pool of ABA conjugates, mediating a faster and stronger release of the active hormone upon subsequent stress challenge by esterases or $\beta$-glucosidases. In tobacco, a large part of pathogen-induced SA is metabolized into SA 2-O- $\beta$-D-glucose (SAG) by SA glucosyltransferase (SAGT) (Edwards, 1994; Lee and Raskin, 1998; Lee and Raskin, 1999; Dean and Mills, 2004; Dean et al., 2005; Song, 2006). This vacuolar pool of SAG could also serve as a source for rapid generation of free SA by a $\beta$-glucosidase (Seo et al., 1995) upon challenge (Dean et al., 2005). Indeed, the SAG and SGE-impaired ugt74fl mutant of Arabidopsis is more susceptible Pst than wild-type plants. Moreover, ugt $74 f 1$ is partially blocked in BABA-IR against this pathogen (Flors, Mauch-Mani unpublished results).

\section{Priming through cross-talk of defence signalling pathways}

Successful defence against a specific pathogen depends on the availability and involvement of the adequate signalling pathway. For this reason, upon attack, the induction of a particular defence pathway usually modifies the activity of other pathways. Priming, via different mechanisms can also potentiate this so-called cross-talk of defence signalling pathways. Plant symbiotic mycorrhizal fungi are presumably regulated by the plant hormone JA (Hause et al., 2007) and its activation facilitates the establishment and development of the symbiotic interaction. Additionally, since the fungal partner in mycorrhiza is a biotroph, it is prone to be sensitive to SA-mediated defence reaction (Glazebrook, 2005). Therefore, it has been suggested that up-regulation of JA-signalling is the result of suppression of the 
SA-dependent pathway by the mycorrhizal fungus (Herrea-Medina et al., 2003). Interestingly, enhanced levels of JA correlate with primed callose deposition in grapevine against Plasmopara (Hamiduzzaman et al., 2005). Indeed, Cordier et al. (1998) observed

\section{A Hormone-ROS-mediated defense}

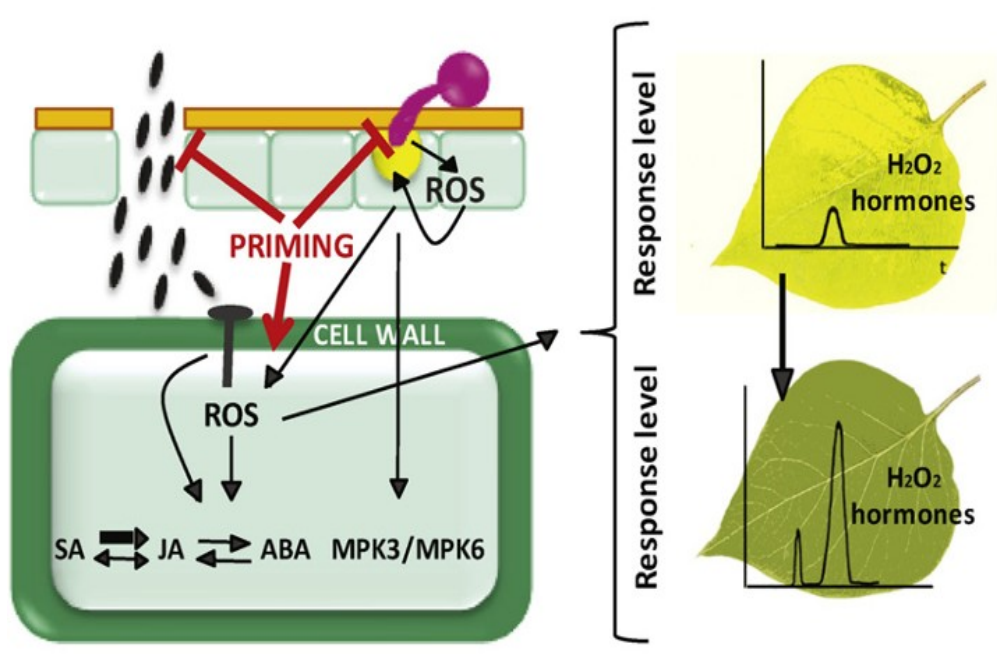

B Storage of glucosilated compounds

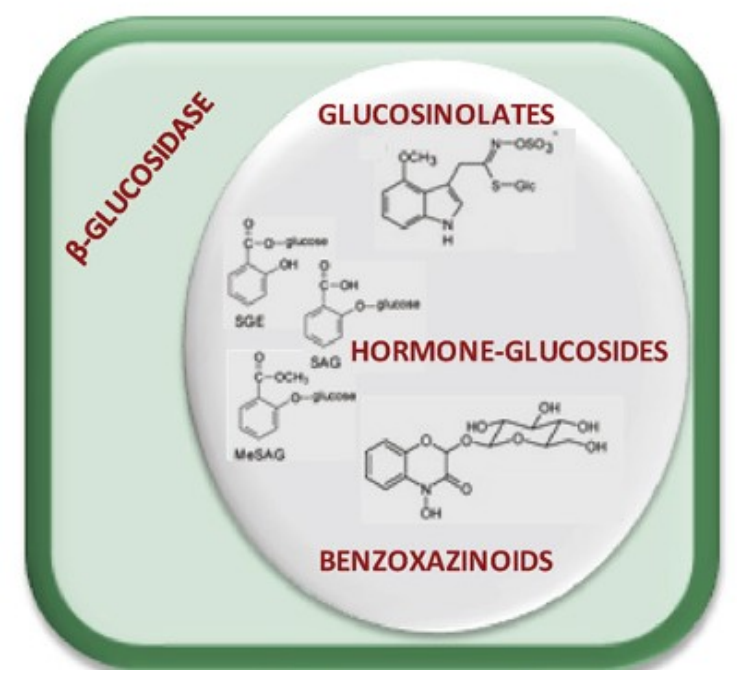

Figure 3. Putative mechanisms of defence priming A) Plants increase their defence responsiveness by activating a second ROS burst upon pathogen attack, which activates downstream accumulation of MPKs and stimulates SA-, ABA- and JAsignalling pathways. B) In primed plants, inactive hormone conjugates and benzoxazinoids can accumulate to higher levels in the vacuole, allowing for a faster and stronger release of the active metabolites upon pathogen/herbivore attack.

priming of papillae formation in the roots of mycorrhiza-infected tomatoes with Phytophthora (Cordier et al., 1998). These observations point to a mechanism by which 
effector-mediated suppression of the SA response results in a beneficial side- effect: systemic priming of JA-dependent defences and callose. The exact long-distance signals controlling this systemic priming in mycorrhizal plants remains unknown, but it has been hypothesized that this is under similar long-distance regulation as systemic auto-regulation of nodulation during interactions between rhizobia and legumes (Zamoundis and Pieterse, 2011).

\section{Enhanced expression of signal transduction proteins: Map kinases and transcription factors.}

Previously, it had been proposed that priming is based on an increased accumulation of defence regulatory protein kinases, which would require a secondary post-translational modification to become active upon subsequent challenging treatment. Similarly, it was suggested that transcription factors crucial for defence gene induction could accumulate to higher levels in primed plants (Conrath et al., 2006). In the meantime, both hypotheses have been validated. Beckers et al. (2009) showed that when Arabidopsis plants are subjected to a priming treatment with the synthetic SAR inducer benzo(1,2,3)thiadiazole-7-carbothioic acid S-methyl ester (BTH), they accumulate increased levels of inactive MAP kinase 3 (MPK3) and MPK6. The increased accumulation of these kinases in BTH-primed plants allows for an augmented kinase activity following secondary stress treatment and a faster and stronger induction of the $P A L$ gene.

Concomitantly, a genome-wide profiling of genes encoding transcription factors (TF) revealed that priming during WCS417r- ISR is associated with an enhanced expression of JA-regulatory TF genes, such as MYC2 or EREBP TFs. On the other hand, the priming of SA-dependent defence upon treatment with BABA was found to correlate with enhanced expression of SA-regulatory $T F$ genes, such as $W R K Y$ s (Van der Ent et al., 2009) Hence, an increased cellular accumulation of defence-related MPKs of TFs can contribute to an augmented defence signalling capacity, mediating faster and stronger transcriptional activation of defence genes after pathogen attack.

However, signalling proteins have limited turn-over times and induced accumulation after application of a single priming stimulus does not seem a satisfactory explanation for the long-lasting nature of induced resistance phenomena associated with defence priming. It seems, therefore, plausible that additional regulatory mechanisms are involved, such as mechanisms associated with epigenetic traits, which can cause longlasting changes in gene responsiveness. Another argument supporting the concept of epigenetic regulation of defence priming comes from its adaptive value for plants in variably hostile environments. Although priming is considered to be beneficial in hostile environments, it is associated with fitness costs under stress-free conditions (van Hulten et al., 2006). Since plant environments rarely impose constant disease pressure, plants would benefit from epigenetically regulated defence priming that is long-lasting but can be reverted after a prolonged decline in disease pressure (Fig. 2). Such mechanism would also allow for inheritance of priming to progeny from disease-exposed plants, which would particularly benefit short-generation plant species, such as Arabidopsis, with a limited ability to outlive disease outbreaks. 


\section{Epigenetic regulation of disease resistance}

\section{Chromatin remodelling and DNA methylation can account for long-lasting changes in gene expression}

Modifications in chromatin structure can have a long-lasting impact on the transcriptional capacity of genes and are commonly based on post-translational modifications (PTM) of histones (Berger, 2007; Kouzarides, 2007; Pfluger and Wagner, 2007; Zhang et al., 2007); or replacements of canonical histone proteins by histone variants (Draker and Cheung, 2009; March-Diaz and Reyes, 2009) (Fig. 4A). PTM of histone proteins include methylation, acetylation, SUMOylation or phosphorylation, which can have different impacts on gene transcription. For instance, modification of the histone $\mathrm{H} 3$ tail by acetylation of lysine $9(\mathrm{H} 3 \mathrm{~K} 9 \mathrm{ac})$ and the trimethylation of lysine $27(\mathrm{H} 3 \mathrm{~K} 27 \mathrm{me} 3)$ are associated with positive and negative effects on gene transcriptional activity, respectively (Pasini et al., 2008; Zhou et al., 2010). Apart from histone acetyltransferase (HAT) and histone deacetylase (HDAC) chromatin remodeling complexes, ATP-dependent remodelling complexes modify chromatin structure by locally disrupting the interaction between DNA and histones (Verbsky and Richards, 2001). Some remodeling complexes control the incorporation of histone variants into the chromatin (de la Serna et al., 2006; March-Diaz et al., 2008). Although histone variants differ marginally from their canonical counterparts, their incorporation into the nucleosome can have a substantial impact on gene transcription (Deal et al., 2007).

In addition to chromatin modification, DNA methylation can have a long-lasting influence on gene transcription as well. DNA methylation involves the addition of a methyl group to the fifth carbon of cytosine. In plants, DNA methylation can occur in either a symmetric $(\mathrm{CpG}$ or $\mathrm{CpNpG})$, or an asymmetric $(\mathrm{CpNpNp})$ manner $(\mathrm{N}=$ nucleotide $)$. DNA methylation at promoters or coding regions typically represses gene transcription. An important mechanism by which plants can achieve targeted DNA methylation is through RNA-directed DNA Methylation (RdDM) (Wassenegger et al., 1994). This form of gene silencing is directed by small interfering RNAs (siRNAs) and depends on the activity of DICER-like 3 (DCL3), Argonaute 4 (AGO4) and the DNA-dependent RNA polymerases Pol IV, and Pol V, and the RNA-dependent polymerase RDR2. RdDM recruits the DOMAIN REARRANGED METHYLTRANSFERASE2 (DRM2) to the targetted DNA site to repress gene transcription (Naumann et al., 2011). SiRNAs can also repress gene transcription by stimulating chromatin-modifying enzymes at RdDM-targeted loci (Herr et al., 2005; Law et al., 2011; Numa et al., 2010).

Although chromatin remodelling and DNA methylation can both have long-lasting impacts on gene transcription, only DNA methylation is known to be transmittable through meiosis and is, therefore, a more plausible mechanism for inheritance of meta-stable epigenetic traits in plans. Within one generation, however, chromatin modifications may serve as a pivotal mechanism to provide long-lasting defence priming against pests and pathogens. 
A Chromatin modification

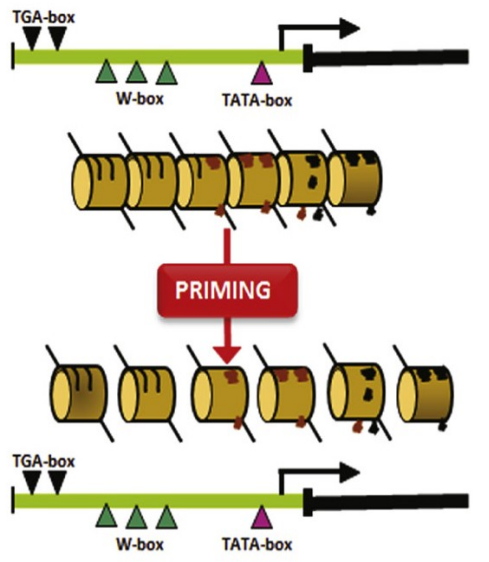

B Trans-generational defence

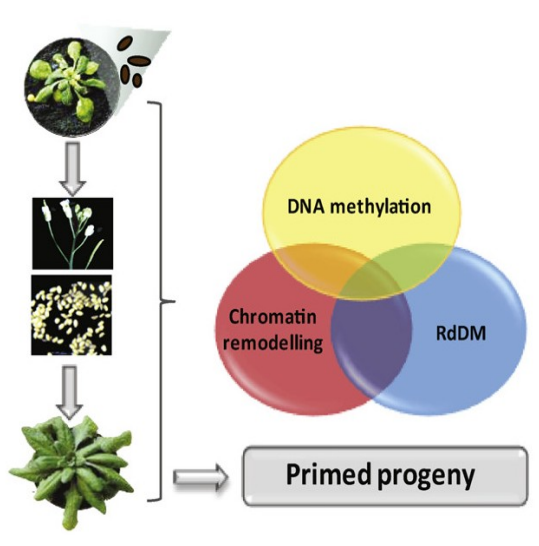

Figure 4. Putative mechanisms of defence priming. A) Long-lasting priming of defence can be based on changes in chromatin structure that could facilitate the transcriptional induction of defence genes upon pathogen attack. B) Biotic stress results in epigenetic changes that are inherited by the following generations, providing priming of defence in the progeny of stressed plants. This trans-generational induced resistance is elicited by the RNA-directed DNA methylation (RdDM) pathway, which triggers heritable changes in DNA methylation and can direct priming-inducing chromatin modifications at defence gene promoters in following generations.

\section{Epigenetic mechanisms controlling disease resistance.}

Over the past decades, chromatin remodelling has emerged as an important regulator of plant defence (Alvarez-Venegas et al., 2007; Bezhani et al., 2007; March-Diaz et al., 2008; Berr et al., 2010). For instance, The SUPRESSOR OF NPR1 INDUCIBLE (SNI1) protein was found to suppress SA-dependent $P R$ gene transcription through repression of histone $\mathrm{H} 3$ acetylation and histone H3K4 methylation (Mosher et al., 2006). In addition, the histone acetyltransferase HDAC19 represses transcription factors, which act negatively on SA- and NPR1-dependent $P R$ gene expression (Kim et al., 2008), whereas the chromatin remodeler protein SPLAYED (SYD) has been implicated in activation of the JAdependent PDF1.2 during infection by the necrotrophic pathogen $B$. cinerea (Walley et al., 2008). March-Diaz et al. (2008) demonstrated an important regulatory role for the histone variant H2A.Z in plant defence. Arabidopsis mutants impaired in the incorporation of H2A.Z exhibit an up-regulation of SA-controlled genes, spontaneous cell death and increased resistance to virulent $P$. syringae (March-Diaz et al., 2008).

RNA interference (RNAi) is primarily an antiviral defence mechanism in plants, but has also been linked to regulation of plant immunity against other pathogens and insects. For instance, components of the miRNA pathway controlling post-translational gene silencing have been associated with basal resistance against pathogens (Agorio and Vera, 2007; Navarro et al., 2008), insect herbivores (Pandey et al., 2008) and nematodes (Hewezi et al., 2008). A possible link between siRNAs, DNA methylation and basal disease resistance was suggested by Agorio and Vera (2007), who demonstrated that $A G O 4$ is required for full basal resistance against $P$. syringae (Agorio and Vera, 2007). Although 
several studies with other RdDM-disrupted mutants revealed no clear role in plant defence (Hailing, 2008; Padmanabhan et al., 2009), we recently demonstrated that the asymmetric DNA methyltransferase $d r m 1 d r m 2 c m t 3(d d c)$ triple mutant of Arabidopsis, which is blocked in RdDM-dependent DNA methylation, is more resistant to biotrophic pathogens, such as $H$. arabidopsidis and P. syringae, whereas it is more susceptible to the necrotrophic fungus Alternaria brassicicola (Luna et al., 2012).

\section{An epigenetic basis for priming?}

The concept of epigenetic control of defence priming has been suggested by several groups (Bruce et al., 2007). A detailed review by Van den Burg and Takken (2009) proposed that H2A.Z and PTM of histones could contribute to priming of SAR-related defence genes (van den Burg and Takken, 2009). Only recently, first experimental evidence for this hypothesis has started to emerge. Berr et al. (2010) showed that induction of JA-dependent defence by JA or fungal infection is accompanied with SDG8-mediated methylation of histone $\mathrm{H} 3 \mathrm{~K} 36$ at promoters of JA-inducible defence genes. They suggested that these structural changes could allow for a long-lasting priming of JA-dependent defence genes against future attacks by necrotrophic fungi (Berr et al., 2010). Moreover, Jaskiewicz et al. (2011) demonstrated that priming of SA-dependent defence is associated with NPR1dependent PTMs of histone $\mathrm{H} 3$ and $\mathrm{H} 4$ tails at gene promoters of defence-regulatory transcription factor genes. Even though these chromatin modifications were studied relatively shortly after SAR induction, an epigenetic basis of priming offers an attractive explanation for the long-lasting nature of the phenomenon.

\section{Trans-generational inheritance of primed defence.}

Although first evidence indeed suggests that priming involves mechanisms that are associated with epigenetic traits, the ultimate proof of concept had to come from the demonstration that primed defence can be inherited into progeny from stimulated isogenic plant lines (Fig. 4B). Trans-generational adaptation to abiotic stress is a phenomenon that has been well documented (Chinnusamy and Zhu, 2009). Exposure of plants to abiotic stress such as radiation, heavy metals, temperature, salt and water all results in increased homologous recombination frequency (HRF) (Boyko et al., 2005; Boyko et al., 2006; Molinier et al., 2006; Yao and Kovalchuk, 2011). Moreover, progeny of plants exposed to these abiotic stresses express a similar increase in HRF, higher DNA methylation levels and enhanced tolerance to stress (Boyko et al., 2010; Molinier et al., 2006). Trans-generational resistance against biotic stress, on the other hand, had not been reported until recently. In tobacco, it was found that progeny of Tobacco Mosaic Virus (TMV)-infected plants show reduced methylation levels of R-gene-like genes (Boyko et al., 2007), increased HRF, and enhanced resistance to different pathogens (Kathiria et al., 2010). We recently demonstrated that Arabidopsis exposed to localised infection by an avirulent strain of $P$. syringae or priming-inducing treatments with BABA produce descendants that are more resistant to $H$. arabidopsidis and Pst DC3000 (Slaughter et al., 2012). In a separate study, we observed similar trans-generational effects in progeny of plants that had repeatedly been infected with the virulent strain of Pst DC3000 (Luna, et al., 2012). Enhanced resistance in these progenies was associated with priming of SA-dependent genes and required an intact NPR1 protein (Luna et al., 2012). At the same time, Rasmann et al. (2012) demonstrated that Arabidopsis and tomato treated with JA or exposed to insect herbivory produce more 
resistant progeny against caterpillar feeding. This trans-generational resistance to herbivory is associated with priming of JA-dependent genes and requires a functional COI1 protein (Rasmann et al., 2012). Furthermore, trans-generational resistance elicited by herbivory or virulent PstDC3000 can be maintained over at least one stress-free generation, indicating that trans-generational resistance is a metastable epigenetic trait that likely involves changes in DNA methylation. Indeed, Rasmann et al. (2012) demonstrated that two Arabidopsis mutants blocked in the RdDM pathway ( $d c l 2 d c l 3 d c l 4$ and $n r p d 2 a$ nrpd2b) failed to produce more resistant progeny. In addition, Luna et al. (2012) demonstrated that priming of SA-related genes in progeny from Pst DC3000-infected plants is associated with changes in the chromatin structure at the defence gene promoters. Moreover, the $d r m 1 d r m 2 \mathrm{cmt} 3$ triple mutant, which is reduced in DNA methylation at non-CpG sites, was found to mimic the priming phenotype of progeny from Pst DC3000-infected wild-type plants. Since Pst DC3000 triggers genome-wide hypomethylation of genomic DNA in Arabidopsis (Pavet et al., 2006), it is plausible that trans-generational priming of SA-dependent defence is based on reduced DNA methylation of regulatory genes. Exactly which regulatory genes become targeted by DNA hypomethylation remains uncertain and the identification of such regulatory epialleles would require a genome-wide sequencing approach of $\mathrm{C}$-methylated genomic DNA.

It had been demonstrated before that infection with the oomycete pathogen H. arabidopsidis and treatments with BTH or INA increase HRF, which could contribute to an increased evolutionary adaptability (Lucht et al., 2002). Moreover, Molinier et al. (2006) demonstrated that this HRF response is heritable and can be detected in progeny from MAMP-treated plants. Boyko and Kovalchuk (2011) proposed a model to explain epigenetic inheritance as part of evolutionary machinery adaptation. They hypothesized that upon stress, plants produce siRNAs, which induce heritable changes in DNA methylation. In following generations, these modifications can be maintained and could induce chromatin remodelling and enhanced recombination events. Since defence priming provides fitness benefits in hostile environments (van Hulten et al., 2006), an epigenetic induction of defence priming could indeed increase fitness levels of entire plant populations under prolonged conditions of disease pressure. The discovery of epigenetically controlled defence priming could also be used for exploitation in sustainable agriculture by selecting for priminginducing epialleles in progenies from induced crop plants.

\section{Concluding remarks}

Priming of defence against biotic stress is an agriculturally attractive phenomenon. Although it has been known for several years that priming can enhance the effectiveness of different plant defence responses, the underpinning molecular mechanisms have remained poorly understood for a long while. Only recently, mechanisms have emerged that could explain to various priming phenomena. It is clear that much of these phenomena are based on a sensitization of hormone-inducible defence responses. One plausible explanation for such sensitization is an increased accumulation of signalling proteins that function in the response pathways of these hormones, which require a secondary post-translational activation upon pathogen attack. A reduced capacity to scavenge ROS could also contribute to this form of priming, since ROS have been shown to regulate hormone-controlled defence responses upon pathogen attack. In addition, the accumulation of vacuole-stored conjugated forms of inactive metabolites and hormones is an attractive complementary hypothesis that 
warrants further investigation in the future. Recently, studies have emerged suggesting that long-lasting priming phenomena are controlled by epi-genetic regulatory mechanisms. Priming of defence genes has been associated with modifications of histone proteins at defence-related gene promoters, which may facilitate access of the gene promoters to the transcriptional machinery. Conclusive evidence for an epigenetic basis of defence priming came very recently from independent laboratories across the world, revealing that priming can be transmitted to following generations in progeny from isogenic plant lines that had been exposed to pathogen or herbivore attack. How the various molecular and epi-genetic mechanisms of priming relate to each other remains unknown and will require further research, which is a critical first step towards large-scale exploitation of the phenomenon in sustainable agriculture.

\section{References}

Agorio, A., Vera, P., 2007. ARGONAUTE4 Is Required for Resistance to Pseudomonas syringae in Arabidopsis. The Plant Cell 198, 3778-3790.

Ahmad, S., Gordon-Weeks, R., Pickett, J., Ton, J., 2010. Natural variation in priming of basal resistance: from evolutionary origin to agricultural exploitation. Molecular Plant Pathology 11, 817-827.

Ahmad, S., Veyrat, N., Gordon-Weeks, R., Zhang, Y., Martin, J., Smart, L., Glauser, G., Erb, M., Flors, V., Frey, M., Ton, J., 2011. Benzoxazinoid Metabolites Regulate Innate Immunity against Aphids and Fungi in Maize. Plant Physiol. 157, 317-327.

Ahn, I., Kim, S., Lee, Y., Suh, S., 2007. Vitamin $B_{1}$-Induced Priming Is Dependent on Hydrogen Peroxide and the NPRI gene in Arabidopsis. Plant Physiol. 143, 838-848.

Alvarez-Venegas, R., Al Abdallat, A., Guo, M., Alfano, J.R., Avramova, Z., 2007. Epigenetic control of a transcription factor at the cross section of two antagonistic pathways. Epigenetics 2, 106-113.

Baker, C., Orlandi, E., 1995. Active Oxygen in Plant Pathogenesis. Annu. Rev. Phytopathol. 33, 299-321.

Barrett, T., Suresh, C., Tolley, S., DODSON, E., HUGHES, M., 1995. The Crystal-Structure of a Cyanogenic Beta-Glucosidase from White Clover, a Family-1 Glycosyl Hydrolase. Structure 3, 951-960.

Barth, C., Jander, G., 2006. Arabidopsis myrosinases TGG1 and TGG2 have redundant function in glucosinolate breakdown and insect defence. Plant Journal 46, 549-562.

Baysal, Ö., Gürsoy, Y.Z., Örnek, H., Çetinel, B., da Silva, J.A.T., 2007. Enhanced systemic resistance to bacterial speck disease caused by Pseudomonas syringae pv. tomato by DL- $\beta$-aminobutyric acid under salt stress. Physiologia Plantarum 129, 493-506.

Beckers, G.J.M., Jaskiewicz, M., Liu, Y., Underwood, W.R., He, S.Y., Zhang, S., Conrath, U., 2009. Mitogen-Activated Protein Kinases 3 and 6 Are Required for Full Priming of Stress Responses in Arabidopsis thaliana. Plant Cell 21, 944-953.

Bednarek, P., Pislewska-Bednarek, M., Svatos, A., Schneider, B., Doubsky, J., Mansurova, M., Humphry, M., Consonni, C., Panstruga, R., Sanchez-Vallet, A., Molina, A., Schulze-Lefert, P., 2009. A Glucosinolate Metabolism Pathway in Living Plant Cells Mediates Broad-Spectrum Antifungal defence. Science 323, 101-106.

Berger, S.L., 2007. The complex language of chromatin regulation during transcription. Nature 447, 407-412. 
Berr, A., McCallum, E.J., Alioua, A., Heintz, D., Heitz, T., Shen, W.-H., 2010. Arabidopsis Histone Methyltransferase SET DOMAIN GROUP8 Mediates Induction of the Jasmonate/Ethylene Pathway Genes in Plant defence Response to Necrotrophic Fungi. Plant Physiology 154, 1403-1414.

Bezhani, S., Winter, C., Hershman, S., Wagner, J.D., Kennedy, J.F., Kwon, C.S., Pfluger, J., $\mathrm{Su}$, Y., Wagner, D., 2007. Unique, Shared, and Redundant Roles for the Arabidopsis SWI/SNF Chromatin Remodeling ATPases BRAHMA and SPLAYED. The Plant Cell Online 19, 403-416.

Boyd, L.A., 2006. Can the durability of resistance be predicted? J. Sci. Food Agric. 86, 2523-2526.

Boyko, A., Kovalchuck, I., 2011. Genome instability and epigenetic modification-heritable responses to environmental stress?. Curr. Opin. Plant Biol. 14, 260-266.

Boyko, A., Blevins, T., Yao, Y., Golubov, A., Bilichak, A., Ilnytskyy, Y., Hollander, J., Meins, F.,Jr., Kovalchuk, I., 2010. Transgenerational Adaptation of Arabidopsis to Stress Requires DNA Methylation and the Function of Dicer-Like Proteins. Plos One 5, e9514.

Boyko, A., Kathiria, P., Zemp, F.J., Yao, Y., Pogribny, I., Kovalchuk, I., 2007. Transgenerational changes in the genome stability and methylation in pathogeninfected plants. Nucleic Acids Research 35, 1714-1725.

Boyko, A., Hudson, D., Bhomkar, P., Kathiria, P., Kovalchuk, I., 2006. Increase of Homologous Recombination Frequency in Vascular Tissue of Arabidopsis Plants Exposed to Salt Stress. Plant and Cell Physiology 47, 736-742.

Boyko, A., Filkowski, J., Kovalchuk, I., 2005. Homologous recombination in plants is temperature and day-length dependent. Mutation Research/Fundamental and Molecular Mechanisms of Mutagenesis 572, 73-83.

Bruce, T.J.A., Matthes, M.C., Napier, J.A., Pickett, J.A., 2007. Stressful "memories" of plants: Evidence and possible mechanisms RID B-8523-2009. Plant Science 173, 603-608.

Camañes, G., Pastor, V., Cerezo, M., García-Andrade, J., Vicedo, B., García-Agustín, P., Flors, V., 2012. A deletion in NRT2.1 attenuates Pseudomonas syringae-induced hormonal perturbation, resulting in primed plant defence. Plant Physiol. In press.

Chinnusamy, V., Zhu, J., 2009. Epigenetic regulation of stress responses in plants RID B9079-2009. Curr. Opin. Plant Biol. 12, 133-139.

Clay, N.K., Adio, A.M., Denoux, C., Jander, G., Ausubel, F.M., 2009. Glucosinolate Metabolites Required for an Arabidopsis Innate Immune Response. Science 323, 95-101.

Cohen, Y.R., 2002. Beta-Aminobutyric Acid-Induced Resistance Against Plant Pathogens. Plant Dis. 86, 448-457.

Colcombet, J., Hirt, H., 2008. Arabidopsis MAPKs: a complex signalling network involved in multiple biological processes. Biochem. J. 413, 217-226.

Conrath, U., 2011. Molecular aspects of defence priming. Trends Plant Sci. 16, 524-531.

Conrath, U., Beckers, G.J.M., Flors, V., Garcia-Agustin, P., Jakab, G., Mauch, F., Newman, M., Pieterse, C.M.J., Poinssot, B., Pozo, M.J., Pugin, A., Schaffrath, U., Ton, J., Wendehenne, D., Zimmerli, L., Mauch-Mani, B., Prime-A-Plant Grp, 2006. Priming: Getting ready for battle RID D-3308-2011 RID A-9326-2011. Mol. PlantMicrobe Interact. 19, 1062-1071.

Cordier, C., Pozo, M., Barea, J., Gianinazzi, S., Gianinazzi-Pearson, V., 1998. Cell defence responses associated with localized and systemic resistance to Phytophthora parasitica induced in tomato by an arbuscular mycorrhizal fungus. Mol. Plant- 
Microbe Interact. 11, 1017-1028.

de la Serna, I., Ohkawa, Y., Imbalzano, A., 2006. Chromatin remodelling in mammalian differentiation: lessons from ATP-dependent remodellers. Nature Reviews Genetics 7, 461-473.

de Vleesschauwer, D., Yang, Y., Cruz, C.V., Höfte, M., 2010. Abscisic acid-induced resistance against the brown spot pathogen Cochliobolus miyabeanus in rice involves MAP kinase-mediated repression of ethylene signaling. Plant Physiol. $152,2036-2052$

Deal, R.B., Topp, C.N., McKinney, E.C., Meagher, R.B., 2007. Repression of flowering in Arabidopsis requires activation of FLOWERING LOCUS $\mathrm{C}$ expression by the histone variant H2A.Z. Plant Cell 19, 74-83.

Dean, J., Mills, J., 2004. Uptake of salicylic acid 2-O-beta-D-glucose into soybean tonoplast vesicles by an ATP-binding cassette transporter-type mechanism. Physiol. Plantarum 120, 603-612.

Dean, J., Mohammed, L., Fitzpatrick, T., 2005. The formation, vacuolar localization, and tonoplast transport of salicylic acid glucose conjugates in tobacco cell suspension cultures. Planta 221, 287-296.

Desikan, R., Macherness, S.A.H., Hancock, J.T., Neill S.J., 2001. Regulation of the Arabidopsis Transcriptome by Oxidative Stress. Plant Physiol. 127, 159-172.

Dietz, K., Sauter, A., Wichert, K., Messdaghi, D., Hartung, W., 2000. Extracellular betaglucosidase activity in barley involved in the hydrolysis of ABA glucose conjugate in leaves RID B-6029-2009. J. Exp. Bot. 51, 937-944.

Ding, X., Cao, Y., Zhao, J., Xu, C., Li, X., Wang, S., 2008. Activation of the indole-3-acetic acid-amido synthethase GH3-8 suppresses expansin expression and promotes salicylate- and jasmonate-independent basal immunity in rice. Plant Cell 20, 228240

Draker, R., Cheung, P., 2009. Transcriptional and epigenetic functions of histone variant H2A.Z. Biochemistry and Cell Biology-Biochimie Et Biologie Cellulaire 87, 19-25.

Dubreuil-Maurizi, C., Trouvelot, S., Frettinger, P., Pugin, A., Wendehenne, D., Poinssot, B., 2010. $\beta$-Aminobutyric Acid Primes and NADPH Oxidase-Dependent Reactive Oxygen Species Production During Grapevine-Triggered Immunity. MPMI 23, 1012-1021.

Durrant, W.E., Dong, X., 2004. Sustemic acquired resistance. Annu. Rev. Phytopathol. 42, 185-209.

Edwards, R., 1994. Conjugation and Metabolism of Salicylic-Acid in Tobacco. J. Plant Physiol. 143, 609-614.

Flors, V., Ton, J., Jakab, G., Mauch-Mani, B., 2005. Abscisic acid and callose: Team players in defence against pathogens? J. Phytopathol. 153, 377-383.

Flors, V., Ton, J., van Doorn, R., Jakab, G., Garcia-Agustin, P., Mauch-Mani, B., 2008. Interplay between JA, SA and ABA signalling during basal and induced resistance against Pseudomonas syringae and Alternaria brassicicola. Plant Journal 54, 81-92.

Flors V, Ton J, Mauch-Mani B. 2009. Role of ABA in disease resistance. In: Signal corsstalk in Plant Stress Responses (eds., Keiko Yoshioka and Kazuo Shinozaki). Publisher: Wiley-Blackwell. DOI:10.1002/9780813805931.ch1

Foyer, C., Noctor, G., 2005. Oxidant and antioxidant signalling in plants: a re-evaluation of the concept of oxidative stress in a physiological context. Plant Cell and Environment 28, 1056-1071.

Frebortova, J., Novak, O., Frebort, I., Jorda, R., 2010. Degradation of cytokinins by maize cytokinin dehydrogenase is mediated by free radicals generated by enzymatic 
oxidation of natural benzoxazinones. Plant Journal 61, 467-481.

Frost, C.J., Mescher, M.C., Carlson, J.E., De Moraes, C.M., 2008. Plant defence priming against herbivores: Getting ready for a different battle. Plant Physiol. 146, 818-824.

Fujita, M., Fujita, Y., Noutoshi, Y., Takahashi, F., Narusaka, Y., Yamaguchi-Shinozaki, K., Shinozaki, K., 2006. Crosstalk between abiotic and biotic stress responses: a current view from the points of convergence in stress signalling networks. Cur. Opin. Plant Biol. 9: 436-442

García-Andarde, J., Ramírez, V., Flors, V., Vera, P., 2011. Arabidopsis ocp3 mutant reveals a mechanism linking $\mathrm{ABA}$ and JA to pathogen-induced callose deposition. Plant J. 67, 783-794.

Glazebrook, J., 2005. Contrasting mechanisms of defence against biotrophic and necrotrophic pathogens. Annu. Rev. Phytopathol. 43, 205-227.

Hailing, J., 2008. Endogenous small RNAs and antibacterial immunity in plants. FEBS Letters 582, 2679-2684.

Hamiduzzaman, M., Jakab, G., Barnavon, L., Neuhaus, J., Mauch-Mani, B., 2005. betaAminobutyric acid-induced resistance against downy mildew in grapevine acts through the potentiation of callose formation and jasmonic acid signalling. Mol. Plant-Microbe Interact. 18, 819-829.

Hause, B., Mrosk, C., Isayenkov, S., Strack, D., 2007. Jasmonates in arbuscular mycorrhizal interactions. Phytochemistry 68,101-110.

Heil, M., Ton, J., 2008. Long-distance signalling in plant defence. Trends Plant Sci. 13, 264272.

Herr, A., Jensen, M., Dalmay, T., Baulcombe, D., 2005. RNA polymerase IV directs silencing of endogenous. Science 308, 118-120.

Herrera Medina, M.J., Gagnon, H., Piché. Y., Ocampo. J.A., García-Garrido, J.M., Vierheilig. H., 2003. Root colonization by arbuscular mycorrhizal fungi is affected by the salicylic acid content of the plant Plant Sci. 164, 993-998

Hewezi, T., Howe, P., Maier, T.R., Baum, T.J., 2008. Arabidopsis Small RNAs and Their Targets During Cyst Nematode Parasitism. Mol. Plant-Microbe Interact. 21, 16221634.

Jakab, G., Cottier, V., Toquin, V., Rigoli, G., Zimmerli, L., Metraux, J.P., Mauch-Mani, B., 2001. beta-Aminobutyric acid-induced resistance in plants. Eur. J. Plant Pathol. 107, 29-37.

Jakab, G., Ton, J., Flors, V., Zimmerli, L., Metraux, J., Mauch-Mani, B., 2005. Enhancing Arabidopsis salt and drought stress tolerance by chemical priming for its abscisic acid responses. Plant Physiol. 139, 267-274.

Jaskiewicz, M., Conrath, U., Peterhansel, C., 2011. Chromatin modification acts as a memory for systemic acquired resistance in the plant stress response. EMBO Rep $12,50-55$

Jia, Z., Zou, B., Wang, X., Qiu, J., Ma, H., Gou, Z., Song, S., Dong, H., 2010. Quercetininduced $\mathrm{H}_{2} \mathrm{O}_{2}$ mediates the pathogen resistance against Pseudomonas syringae pv. Tomato DC3000 in Arabidopsis thaliana. Biochemical and Biophysical Research Communications 396, 522-527.

Jones, J.D.G., Dangl, J.L., 2006. The plant immune system. Nature 444, 323-329.

Jung, H.W., Tschaplinski, T.J., Wang, L., Glazebrook, J., Greenberg, J.T., 2009. Priming in Systemic Plant Immunity RID D-4021-2009. Science 324, 89-91.

Kaiser, G., Weiler, E., Hartung, W., 1985. The Intracellular-Distribution of Abscisic-Acid in Mesophyll-Cells - the Role of the Vacuole. J. Plant Physiol. 119, 237-245. 
Kathiria, P., Sidler, C., Golubov, A., Kalischuk, M., Kawchuk, L.M., Kovalchuk, I., 2010. Tobacco Mosaic Virus Infection Results in an Increase in Recombination Frequency and Resistance to Viral, Bacterial, and Fungal Pathogens in the Progeny of Infected Tobacco Plants. Plant Physiol. 153, 1859-1870.

Kauss, H., Jeblick, W., 1995. Pretreatment of parsley suspension cultures with salicyli acid enhances spontaneous and elicited production of $\mathrm{H}_{2} \mathrm{O}_{2}$. Plant Physiol 108: 11711178 .

Kim, K., Lai, Z., Fan, B., Chen, Z., 2008. Arabidopsis WRKY38 and WRKY62 Transcription Factors Interact with Histone Deacetylase 19 in Basal defence. Plant Cell 20, 2357-2371.

Kohler, A., Schwindling, S., Conrath, U., 2002. Benzothiadiazole-induced priming for potentiated responses to pathogen infection, wounding, and infiltration of water into leaves requires the NPR1/NIM1 gene in Arabidopsis. Plant Physiol. 128, 10461056.

Kouzarides, T., 2007. Chromatin modifications and their function. Cell 128, 693-705.

Laloi, C., Apel, K., Danon, A., 2004. Reactive oxygen signalling: the latest news. Current Opinion in Plant Biology 7, 323-328.

Law, J.A., Vashisht, A.A., Wohlschlegel, J.A., Jacobsen, S.E., 2011. SHH1, a Homeodomain Protein Required for DNA Methylation, As Well As RDR2, RDM4, and Chromatin Remodeling Factors, Associate with RNA Polymerase IV RID A-9566-2011. Plos Genetics 7, e1002195.

Lee, H., Raskin, I., 1999. Purification, cloning, and expression of a pathogen inducible UDP-glucose: Salicylic acid glucosyltransferase from tobacco. J. Biol. Chem. 274, 36637-36642.

Lee, H., Raskin, I., 1998. Glucosylation of salicylic acid in Nicotiana tabacum cv. Xanthinc. Phytopathology 88, 692-697.

Lenman, M., Falk, A., Rodin, J., Hoglund, A.S., Ek, B., Rask, L., 1993. Differential Expression of Myrosinase Gene Families. Plant Physiol. 103, 703-711.

Lucht, J., Mauch-Mani, B., Steiner, H., Metraux, J., Ryals, J., Hohn, B., 2002. Pathogen stress increases somatic recombination frequency in Arabidopsis. Nat. Genet. 30, 311-314.

Luna, E., Pastor, V., Robert, J., Flors, V., Mauch-Mani, B., Ton, J., 2011. Callose Deposition: A Multifaceted Plant defence Response. Mol. Plant-Microbe Interact. 24, 183-193.

Luna, E., Bruce TJA, Roberts MR, Flors V, Ton J., 2012.Next Generation Systemic Acquired Resistance. Plant Physiology. In press

March-Diaz, R., Garcia-Dominguez, M., Lozano-Juste, J., Leon, J., Florencio, F.J., Reyes, J.C., 2008. Histone H2A.Z and homologues of components of the SWR1 complex are required to control immunity in Arabidopsis. Plant Journal 53, 475-487.

March-Diaz, R., Reyes, J.C., 2009. The Beauty of Being a Variant: H2A.Z and the SWR1 Complex in Plants. Molecular Plant 2, 565-577.

Mauch-Mani, B., Flors, V., 2009. The ATAF1 transcription factor: At the convergence point of ABA-dependent plant defence agianst biotic and abiotic stresses. Cell Research 19, 1322-132

Mauch-Mani, B., Mauch, F., 2005. The role of abscisic acid in plant-pathogen interactions. Curr. Opin. Plant Biol. 8, 409-414.

Melotto, M., Underwood, W., He, S.Y., 2008. Role of stomata in plant innate immunity and foliar bacterial diseases. Annu. Rev. Phytopathol. 46, 101-122.

Melotto, M., Underwood, W., Koczan, J., Nomura, K., He, S.Y., 2006. Plant stomata 
function in innate immunity against bacterial invasion. Cell 126, 969-980.

Mittler, R., Vanderauwera, S., Suzuki, N., Miller, G., Tognetti, V.B., Vandepoele, K., Gollery, M., Shulaev, V., Van Breusegem, F., 2011. ROS signalling: the new wave? Trends Plant Sci. 16, 300-309.

Mittler, R, Vanderauwera, S., Gollery, M., van Breusegem, F., 2004. Reactive oxygen gene network of plants. Trends Plant Sci. 9, 490-498.

Molinier, J., Ries, G., Zipfel, C., Hohn, B., 2006. Transgeneration memory of stress in plants RID D-7103-2011. Nature 442, 1046-1049.

Moller, I.M., Jensen, P.E., Hansson, A., 2007. Oxidative modifications to cellular components in plants. Annual Review of Plant Biology 58, 459-481.

Morant, A.V., Jorgensen, K., Jorgensen, C., Paquette, S.M., Sanchez-Perez, R., Moller, B.L., Bak, S., 2008. beta-glucosidases as detonators of plant chemical defence. Phytochemistry 69, 1795-1813.

Mosher, R.A., Durrant, W.E., Wang, D., Song, J., Dong, X., 2006. A comprehensive structure-function analysis of Arabidopsis SNI1 defines essential regions and transcriptional repressor activity . Plant Cell 18, 1750-1765.

Mukherjee, M., Larrimore, K.E., Ahmed, N.J., Bedick, T.S., Barghouthi, N.T., Traw, M.B., Barth, C., 2010. Ascorbic Acid Deficiency in Arabidopsis Induces Constitutive Priming That is Dependent on Hydrogen Peroxide, Salicylic acid, and the NPRI gene. MPMI 23, 340-351.

Mur, L.A.J., Lloyd, A.J., Cristescu, S.M., Harren, F.J.M., Hall, M.A., Smith, A.R., 2009. Biphasic ethylene production during the hypersensitive response in arabidopsis. Plant signalling Behavior 7, 610-613.

Mur, L.A.J., Laarhoven, L.J.J., Harren, F.J.M., Hall, M.A., Smith, A.R., 2008. Nitric Oxide Interacts with Salicylate to Regulate Biphasic Ethylene Production during the Hypersensitive Response. Plant Physiol. 148, 1537-1546.

Naumann, U., Daxinger, L., Kanno, T., Eun, C., Long, Q., Lorkovic, Z.J., Matzke, M., Matzke, A.J.M., 2011. Genetic Evidence That DNA Methyltransferase DRM2 Has a Direct Catalytic Role in RNA-Directed DNA Methylation in Arabidopsis thaliana. Genetics 187, 977-979.

Navarro, L., Jay, F., Nomura, K., He, S.Y., Voinnet, O., 2008. Suppression of the microRNA pathway by bacterial effector proteins. Science 321, 964-967.

Neill, S., Desikan, R., Hancock, J., 2002. Hydrogen peroxide signalling. Current Opinion in Plant Biology 5, 388-395.

Numa, H., Kim, J., Matsui, A., Kurihara, Y., Morosawa, T., Ishida, J., Mochizuki, Y., Kimura, H., Shinozaki, K., Toyoda, T., Seki, M., Yoshikawa, M., Habu, Y., 2010. Transduction of RNA-directed DNA methylation signals to repressive histone marks in Arabidopsis thaliana. EMBO J. 29, 352-362.

Padmanabhan, C., Zhang, X., Jin, H., 2009. Host small RNAs are big contributors to plant innate immunity. Curr Opin Plant Biol 12, 465-472.

Pandey, S.P., Shahi, P., Gase, K., Baldwin, I.T., 2008. Herbivory-induced changes in the small-RNA transcriptome and phytohormone signalling in Nicotiana attenuata. Proc. Natl. Acad. Sci. U. S. A. 105, 4559-4564.

Pasini, D., Hansen, K.H., Christensen, J., Agger, K., Cloos, P.A.C., Helin, K., 2008. Coordinated regulation of transcriptional repression by the RBP2 H3K4 demethylase and Polycomb-Repressive Complex 2. Genes Dev. 22, 1345-1355.

Pavet, V., Quintero, C., Cecchini, N.M., Rosa, A.L., Alvarez, M.E., 2006. Arabidopsis displays centromeric DNA hypomethylation and cytological alterations of heterochromatin upon attack by Pseudomonas syringae. Mol. Plant-Microbe 
Interact. 19, 577-587.

Pfluger, J., Wagner, D., 2007. Histone modifications and dynamic regulation of genome accessibility in plants. Curr. Opin. Plant Biol. 10, 645-652.

Pieterse, C.M.J., León-Reyes, A., van der Ent, S., van Wees, S.C.M., 2009. Networking by small-molecule hormones in plant immunity. Nature Chemical Biology 5, 308-316.

Pieterse, C.M.J., van Wees, S.C.M., van Pelt, J.A., Knoester, M., Laan, R., Gerrits, H., Weisbeek, P.J., van Loon, L.C., 1998. A novel signalling pathway controlling induced systemic resistance in Arabidopsis. Plant Cell 10, 1571-1580.

Pozo, M.J., Van Der Ent, S., Van Loon, L.C., Pieterse, C.M.J., 2008. Transcription factor MYC2 is involved in priming for enhanced defence during rhizobacteria-induced systemic resistance in Arabidopsis thaliana RID A-9326-2011. New Phytol. 180, 511-523.

Rasmann. S., De Vos, M., Casteel, C.L., Tian, D., Halitschke. R., Sun. J.Y., Agrawal. A.A., Felton, G.W., Jander. G., 2012. Herbivory in the previous generation primes Arabidopsis and tomato for enhanced insect resistance. Plant Physiology. In press

Schulze-Lefert, P., Robatzek, S., 2006. Plant pathogens trick guard cells into opening the gates RID A-7746-2008. Cell 126, 831-834.

Sauter, A., Dietiz, J.K., Hartung, W., 2002. A possible stress physiological role of abscisic acid conjugates in root-to-shoot signalling. Plant, Cell and Environment 25, $223-$ 228

Seo, S., Ishizuka, K., Ohashi, Y., 1995. Induction of Salicylic-Acid Beta-Glucosidase in Tobacco-Leaves by Exogenous Salicylic-Acid. Plant and Cell Physiology 36, 447453.

Shetty, N.P., Jorgensen, H.J.L., Jensen, J.D., Collinge, D.B., Shetty, H.S., 2008. Roles of reactive oxygen species in interactions between plants and pathogens RID G-49462011. Eur. J. Plant Pathol. 121, 267-280.

Slaughter, A., Daniel, X., Flors, V., Luna, E., Hohn, E., Mauch-Mani, B., 2012. Descendants of primed Arabidopsis plants exhibit resistance to biotic stress. Plant Physiol. In press

Song, J.T., 2006. Induction of a salicylic acid glucosyltransferase, AtSGT1, is an early disease response in Arabidopsis thaliana. Mol. Cells 22, 233-238.

Taheri, P., Tarighi, S., 2011. A survey on basal resistance and riboflavin-induced defence responses of sugar beet against Rhizoctonia solani.J. Plant Physiol. 168, 1114-1122.

Taheri, P., Tarighi, S., 2010. Rivoflavin induces resistance in rice against Rhizoctonia solani via jasmonate-mediated priming of phenylpropanoid pathway. J. Plant Physiol. 167, 201-208.

Ton, J., Jakab, G., Toquin, V., Flors, V., Iavicoli, A., Maeder, M.N., Metraux, J.P., MauchMani, B., 2005. Dissecting the beta-aminobutyric acid-induced priming phenomenon in Arabidopsis. Plant Cell 17, 987-999.

Ton, J., Mauch-Mani, B., 2004. beta-amino-butyric acid-induced resistance against necrotrophic pathogens is based on ABA-dependent priming for callose. Plant Journal 38, 119-130.

Ton, J., Van Pelt, J.A., Van Loon, L.C., Pieterse, C.M.J., 2002. Differential effectiveness of salicylate-dependent and jasmonate/ethylene-dependent induced resistance in Arabidopsis. Mol. Plant-Microbe Interact. 15, 27-34.

Ton, J., D'Alessandro, M., Jourdie, V., Jakab, G., Karlen, D., Held, M., Mauch-Mani, B., Turlings, T.C.J., 2007. Priming by airborne signals boosts direct and indirect resistance in maize. Plant Journal 49, 16-26.

Ton, J., Flors, V., Mauch-Mani, B., 2009. The multifaceted role of ABA in disease 
resistance. Trends Plant Sci. 14, 310-317.

Truman, W.M., Bennett, M.H., Turnbull, C.G.N., Grant, M.R., 2010. Arabidopsis Auxin Mutants Are Compromised in Systemic Acquired Resistance and Exhibit Aberrant Accumulation of Various Indolic Compounds RID B-4742-2008. Plant Physiol. 152, 1562-1573.

Tsai, C., Singh, P., Chen, C., Thomas, J., Weber, J., Mauch-Mani, B., Zimmerli, L., 2011. Priming for enhanced defence responses by specific inhibition of the Arabidopsis response to coronatine. Plant Journal 65, 469-479.

Turlings, T.C.J., Ton, J., 2006. Exploiting scents of distress: the prospect of manipulating herbivore-induced plant odours to enhance the control of agricultural pests. Curr. Opin. Plant Biol. 9, 421-427.

Unger, C., Kleta, S., Jandl, G., von Tiedemann, A., 2005. Suppression of the defence-related oxidative burst in bean leaf tissue and bean suspension cells by the necrotrophic pathogen Botrytis cinerea. J. Phytopathol. 153, 15-26.

van den Burg, H.A., Takken, F.L.W., 2009. Does chromatin remodeling mark systemic acquired resistance? Trends Plant Sci. 14, 286-294.

van der Ent, S., Van Hulten, M., Pozo, M.J., Czechowski, T., Udvardi, M.K., Pieterse, C.M.J., Ton, J., 2009. Priming of plant innate immunity by rhizobacteria and betaaminobutyric acid: differences and similarities in regulation RID A-9326-2011. New Phytol. 183, 419-431.

van Hulten, M., Pelser, M., van Loon, L., Pieterse, C., Ton, J., 2006. Costs and benefits of priming for defence in Arabidopsis RID A-9326-2011. Proc. Natl. Acad. Sci. U. S. A. $103,5602-5607$.

van Wees, S.C.M., Van der Ent, S., Pieterse, C.M.J., 2008. Plant immune responses triggered by beneficial microbes RID B-8595-2011 RID A-9326-2011. Curr. Opin. Plant Biol. 11, 443-448.

Verbsky, M., Richards, E., 2001. Chromatin remodeling in plants. Curr. Opin. Plant Biol. 4, 494-500.

Verdoucq, L., Moriniere, J., Bevan, D., Esen, A., Vasella, A., Henrissat, B., Czjzek, M., 2004. Structural determinants of substrate specificity in family 1 beta-glucosidases Novel insights from the crystal structure of sorghum dhurrinase-1, a plant betaglucosidase with strict specificity, in complex with its natural substrate. J. Biol. Chem. 279, 31796-31803.

Verhagen, B.W.M., Glazebrook, J., Zhu, T., Chang, H.S., van Loon, L.C., Pieterse, C.M.J., 2004. The transcriptome of rhizobacteria-induced systemic resistance in Arabidopsis. Mol. Plant-Microbe Interact. 17, 895-908.

Vicedo, B., Flors, V., de la O Leyva, M., Finiti, I., Kravchuck, Z., Real, M.D., GarcíaAgustín, P., González-Bosch, C., 2009. Hexanoic acid-induced resistance against Botrytis cinerea in tomato plants. MPMI 22, 1455-1465.

von Rad, U., Huttl, R., Lottspeich, F., Gierl, A., Frey, M., 2001. Two glucosyltransferases are involved in detoxification of benzoxazinoids in maize. Plant Journal 28, 633642.

Walley, J.W., Rowe, H.C., Xiao, Y., Chehab, E.W., Kliebenstein, D.J., Wagner, D., Dehesh, K., 2008. The Chromatin Remodeler SPLAYED Regulates Specific Stress signalling Pathways RID C-9284-2011. Plos Pathogens 4, e1000237.

Wassenegger, M., Heimes, S., Riedel, L., Sanger, H., 1994. Rna-Directed De-Novo Methylation of Genomic Sequences in Plants. Cell 76, 567-576.

Wawrzynska, A., Christiansen, K.M., Lan, Y., Rodibaugh, N.L., Innes, R.W., 2008. Powdery Mildew Resistance Conferred by Loss of the ENHANCED DISEASE 
RESISTANCE1 Protein Kinase Is Suppressed by a Missense Mutation in KEEP ON GOING, a Regulator of Abscisic Acid Signaling. Plant Physiol. 148, 1510-1522.

Yao, Y., Kovalchuk, I., 2011. Abiotic stress leads to somatic and heritable changes in homologous recombination frequency, point mutation frequency and microsatellite stability in Arabidopsis plants. Mutat. Res. -Fundam. Mol. Mech. Mutag. 707, 6166.

Yao, Y., Dannab, C.H., Zempd, F.J., Titova, V., Ciftcie, O.N., Przybylskie, R., Ausubel, F.M., Kovalchuka, I., 2011. UV-C-Irradiated Arabidopsis and Tobacco Emit Volatiles That Trigger Genomic Instability in Neighboring Plants. Plant Cell. 23, 3842-3852.

Zamioudis, C., Pieterse, C.M.J., 2011. Modulation of Host Immunity by Beneficial Microbes. MPMI. DOI:10.1094/MPMI-06-11-0179

Zhang, K., Sridhar, V.V., Zhu, J., Kapoor, A., Zhu, J., 2007. Distinctive Core Histone PostTranslational Modification Patterns in Arabidopsis thaliana. Plos One 2, e1210.

Zhang, S., Yang, X., Sun, M., Sun, F., Deng, S., Dong, H., 2009. Rivoflavin-induced Priming for Pathogen defence in Arabidopsis thaliana. Journal of Integrative Plant Biology 51, 167-174.

Zhang, Z., Li, Q., Li, Z., Staswick, P.E., Wang, M., Zhu, Y., He, Z., 2007. Dual regulation role of GH3.5 in salicilyc acid and auxin signalling during ArabidopsisPseudomonas syringae interaction. Plant Physiol. 145, 450-464.

Zhou, J., Wang, X., He, K., Charron, J.F., Elling, A.A., Deng, X.W., 2010. Genome-wide profiling of histone $\mathrm{H} 3$ lysine 9 acetylation and dimethylation in Arabidopsis reveals correlation between multiple histone marks and gene expression. Plant Mol. Biol. 72, 585-595.

Zimmerli L., Jakab C., Metraux J. P., Mauch-Mani B., 2000. Potentiation of pathogenspecific defence mechanisms in Arabidopsis by beta-aminobutyric acid. Proc. Natl. Acad. Sci. U.S.A. 97, 12920-12925. 

CHAPTER 2

Callose Deposition: A multifaceted Plant

defence Response 


\begin{abstract}
Callose deposition in Arabidopsis has emerged as a popular model system to quantify activity of plant immunity. However, there has been a noticeable rise in contradicting reports about the regulation of pathogen-induced callose. To address this controversy, we have examined the robustness of callose deposition under different growth conditions and in response to two different pathogen-associated molecular patterns: the flagellin epitope Flg22 and the polysaccharide chitosan. Based on a commonly used hydroponic cultivation system, we found that variations in growth conditions have major impacts on the plant's overall capacity to deposit callose. This environmental variability correlated with levels of hydrogen peroxide $\left(\mathrm{H}_{2} \mathrm{O}_{2}\right)$ production. Depending on the growth conditions, pre-treatment with abscisic acid stimulated or repressed callose deposition. Despite similar impacts of growth conditions on Flg22- and chitosan-induced callose, both responses showed differences in timing, tissue responsiveness, and co-localisation with $\mathrm{H} 2 \mathrm{O} 2$. Furthermore, mutant analysis revealed that Flg22- and chitosan-induced callose differ in the requirement for the NADPH oxidase RBOHD, the glucosinolate regulatory enzymes VTC1 and PEN2, and the callose synthase PMR4. Our study demonstrates that callose is a multifaceted defence response that is controlled by distinct signalling pathways, depending on the environmental conditions and the challenging PAMP.
\end{abstract}




\section{Introduction}

Plants protect themselves against pathogens with a variety of chemical and physical defence mechanisms. Callose-containing cell wall appositions, called papillae, are effective barriers induced at the sites of attack during the relatively early stages of pathogen invasion. Callose is an amorphous, high-molecular-weight $\beta$ - $(1,3)$-glucan polymer that serves as a matrix in which antimicrobial compounds can be deposited, thereby providing focussed delivery of chemical defences at the cellular sites of attack. Callose deposition is typically triggered by conserved pathogen-associated molecular patterns (PAMPs; Brown et al. 1998; Gomez-Gomez et al. 1999a). Examples of bacterial PAMPs are the 22 amino acid sequence of the conserved N-terminal part of flagellin (Gomez-Gomez and Boller 2000) and the bacterial elongation factor EF-Tu (Elf18; Kunze et al. 2004). Chitin, a B-(1,4)-linked polymer of $\mathrm{N}$-acetylglucosamine, and chitosan, a randomly distributed $\beta$-(1,4)-linked polymer of D-glucosamide and acetylglucosamine, are examples of potent callose-inducing PAMPs in fungal cell walls (Iritri and Faoro 2009). Apart from PAMPs, endogenous elicitors from pathogen- or herbivore-damaged plant tissues can activate callose depositions as well. Well-known examples of damage-associated patterns (DAMPS) are oligogalacturonides. (OGs; Ridley et al. 2001).

The signalling pathways controlling PTI are under control by pathogen recognition receptors (PRRs). Downstream pathways are marked by common signalling events, such as anion fluxes, protein phosphorylation cascades, accumulation of reactive oxygen species (ROS) and defence gene induction (Boller and Felix 2009; Jeworutzki et al. 2010; Nicaise et al. 2009). Recently, PAMP/DAMP-induced callose deposition in cotyledons or leaves of Arabidopsis has emerged as a popular marker response to study the signalling pathways controlling PTI, or the suppression of these pathways by virulence-promoting pathogen effectors (Table I). The advantage of this model system is that it allows for rapid and relatively simple screening of PTI activity. The model system has been used to demonstrate that reactive oxygen species (ROS) act as positive signals in Flg22- and OG-induced callose (Galletti et al. 2008; Zhang et al. 2007), and recently it was found that the RNA interference regulatory protein, Argonaute1, generates various miRNA signals that stimulate or repress Flg22-induced callose ( $\mathrm{Li}$ et al. 2010). Furthermore, Flg22-induced callose in Arabidopsis has been demonstrated to require intact biosynthesis of 4-methoxylated indole glucosinolates (Clay et al. 2009), suggesting that these secondary metabolites, or breakdown products thereof, play a crucial role in the regulation of callose.

The timing and intensity of pathogen-induced callose can be influenced by environmental signals. For example, plants that are locally subjected to pathogen attack express systemic acquired resistance (SAR), which is associated with augmented levels of callose upon secondary pathogen inoculation (Kohler et al. 2002). Furthermore, resistanceinducing chemicals can augment depositions of pathogen-inducible callose. Well-known examples of such priming agents are the salicylic acid (SA) analogue benzo(1,2,3) thiadiazole-7-carbothioic acid S-methyl ester (BTH; Kohler et al. 2002), and the non-protein amino acid beta-amino butyric acid (BABA; Ton and Mauch-Mani 2004; Zimmerli et al. 2000). Furthermore, we have previously demonstrated that BABA-induced priming of callose requires an intact abscisic acid (ABA)-dependent pathway in Arabidopsis. Since ABA regulates plant adaptation to abiotic stress, these findings suggested that pathogeninduced callose is co-regulated by abiotic stress signals (Flors et al. 2005; Mauch-Mani and 
Mauch 2005). Indeed, over recent years ABA has emerged as a multifaceted modulator of disease resistance (Asselbergh et al. 2008; Ton et al. 2009).

\begin{tabular}{|c|c|c|c|}
\hline Experimental system & PAMP & Signaling process & Reference \\
\hline Application to hydroponically grown seedlings & $\begin{array}{l}\text { Flg22, chitin, } \\
\text { peptidoglycan }\end{array}$ & $\begin{array}{l}\text { Induction of PTI and effector-triggered } \\
\text { suppression of PTI in roots. }\end{array}$ & Millet et al. 2010 \\
\hline Infiltration in leaves & $\mathrm{Flg} 22$ & $\begin{array}{l}\text { Regulation of defense gene expression by } \\
\text { miRNAs }\end{array}$ & Li et al. 2010 \\
\hline Application to hydroponically grown seedlings & Flg22, Elf18 & Poly(ADP-ribosyl)ation & Adams-Phillips et al. 2010 \\
\hline Application to hydroponically grown seedlings & Flg22, Elf18 & PRR quality control in the ER & Lu et al. 2009 \\
\hline Application to hydroponically grown seedlings & Flg22, Elf18 & PRR quality control in the ER & Saijo et al. 2009 \\
\hline Infiltration in leaves & Flg22 & PAMP activity by bacterial DNA & Yakushiji et al. 2009 \\
\hline Infiltration in leaves & Flg 22 & Induction of salicylic acid accumulation & Wang et al. 2009 \\
\hline Application to hydroponically grown seedlings & Flg22 & Induction of glucosinolate metabolites & Clay et al. 2009 \\
\hline Infiltration in leaves & Oligogalacturonides & Reactive oxygen species signaling & Galletti et al. 2008 \\
\hline Infiltration in leaves & $\mathrm{Flg} 22$ & $\begin{array}{l}\text { Protein phosphorylation and reactive oxygen } \\
\text { species signaling }\end{array}$ & Zhang et al. 2007 \\
\hline Infiltration in leaves & $\mathrm{Flg} 22$ & $\begin{array}{l}\text { Effector-triggered suppression of PTI via } \\
\text { ADP ribosylation. }\end{array}$ & Fu et al. 2007 \\
\hline Application to hydroponically grown seedlings & Flg 22 & Activity of the FLS2 receptor & Dunning et al. 2007 \\
\hline
\end{tabular}

Table 1: Recent publications that have used PAMP-induced callose deposition in Arabidopsis as a marker for PTI activity ${ }^{\mathrm{a}}$

The role of ABA in disease resistance depends on a multitude of factors, such as the attacking pathogen, its specific way of gaining entry into the host, the timing of the defence response and the type of plant tissue that is under attack. In general, ABA exerts a positive influence on early-acting defences, such as stomatal closure, but a negative influence on later-acting defence mechanisms that are under control by plant hormones SA and jasmonic acid (JA; Ton et al. 2009). Nevertheless, this trend does not explain the controversial function of ABA in pathogen-induced callose. It was recently reported that ABA suppresses callose deposition in Arabidopsis cotyledons after treatment with the bacterial PAMP flagellin (Clay et al. 2009), which is supported by earlier findings that callose induced by Pseudomonas syringae pv. tomato is suppressed by ABA (de Torres-Zabala et al. 2007). Contrary to these findings, other groups have demonstrated a positive influence of ABA on callose deposition in response to infection by different fungal and oomycete pathogens (Asselbergh et al. 2008; Flors et al. 2005; Ton et al. 2009). In fact, a DNA/RNA nuclease was recently reported as a critical regulator of ABA-dependent callose deposition in response to Botrytis cinerea infection (You et al. 2010).

In this study, we have evaluated the robustness of a widely used hydroponic Arabidopsis system to quantify PAMP-induced callose. Our results demonstrate that variations in abiotic growth conditions have a major impact on the plant's capacity to deposit callose in this system, which correlate with levels of $\mathrm{H}_{2} \mathrm{O}_{2}$ in the tissue. Moreover, the impact of $\mathrm{ABA}$ on callose deposition varied from repressive to stimulatory, depending on the growth conditions. We furthermore demonstrate that the pathways controlling callose differ according to the challenging PAMP, illustrating that pathogen-induced callose is a multifaceted defence response that is regulated by multiple signals, rather than one conserved signalling pathway.

\section{Results}

Flg22- and chitosan-induced callose in hydroponically grown Arabidopsis.

To make a direct comparison between Flg22- and chitosan-induced callose, 
Arabidopsis seedlings were grown at $150 \mu$ E.m-2.s-1 light in hydroponic Murashige and Skoog medium, containing $1 \%$ sucrose without Gamborg vitamins. At $24 \mathrm{~h}$ after application of $1 \mu \mathrm{M}$ Flg22, or $0.01 \%$ chitosan (w/v), cotyledons were collected, stained with aniline blue and examined by UV epifluoresence microscopy. As is illustrated in Fig. 1a, both PAMP treatments caused a noticeable increase in the amount of callose depositions. However, the size of individual callose depositions in chitosan-treated plants appeared larger than those from Flg22-treated plants. To enumerate these differences, callose was quantified from digital photographs and expressed as the relative number of callose-corresponding pixels (callose intensity), or the relative number of callose depositions. Whereas the number of depositions did not differ between Flg22- and chitosan-treated seedlings, the callose intensity was significantly higher in response to chitosan compared to Flg22 (Fig. 1b). Hence, $0.01 \%$ chitosan triggers higher amounts of callose per deposition than $1 \mu \mathrm{M}$ Flg22. Further dose-response analysis revealed that this difference in callose morphology was also apparent at other concentrations of the applied PAMPs (Fig. S1; data no shown). Since $1 \mu \mathrm{M}$ flg22 and $0.01 \%$ chitosan yielded the most consistent levels of callose elicitation between independent experiments, subsequent experiments were carried out with these doses, unless stated otherwise.

(a)
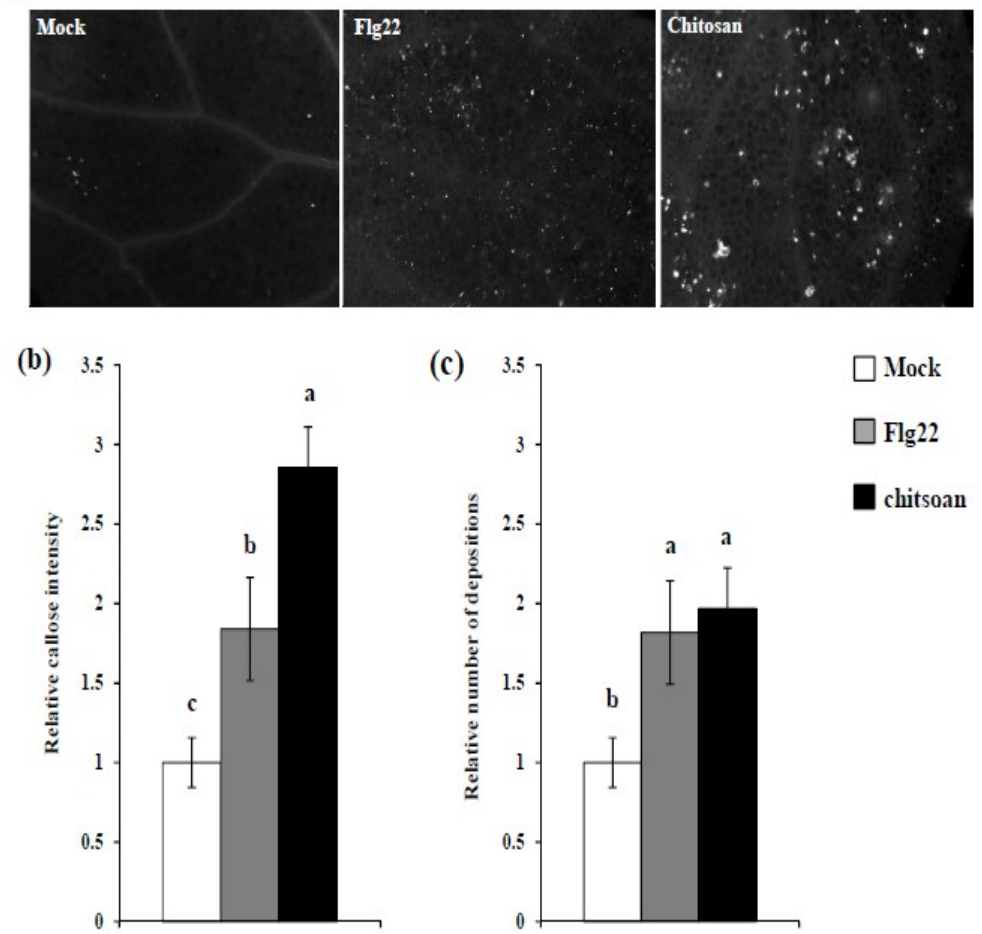

Figure 1: Phenotype of Flg22- and chitosan-induced callose. (a): Morphologic differences between callose depositions in cotyledons of 9-day old Arabidopsis seedlings (Col-0) at $24 \mathrm{~h}$ after mock treatment, $1 \mu \mathrm{M} \mathrm{Flg} 22$, or $0.01 \%$ chitosan. Photographs of aniline-blue-stained cotyledons under UV epifluorescence show representative differences in callose depositions between treatments. Seedlings were cultivated at $150 \mu \mathrm{E} . \mathrm{m}-2 . \mathrm{s}-1$ light in liquid MS medium containing $1 \%$ sucrose without Gamborg vitamins (b): Relative callose intensities were quantified as the number of fluorescent callosecorresponding pixels relative to the total number of pixels covering plant material. Values represent means $( \pm$ SEM; $n>20)$ standardised to the mean callose intensity in mock-treated seedlings. (c): relative numbers of callose depositions were quantified as the number of individual depositions per unit cotyledon surface. Values represent means $( \pm$ SEM; $n>20)$, standardised to the mean number in mock-treated seedlings. Different letters indicate statistically significant differences between treatments (Fisher's LSD test; $\alpha=0.05$ ). 


\section{Impact of growth conditions on callose deposition.}

Levels of Flg22- and chitosan-induced callose in hydroponically cultivated Arabidopsis were measured under different environmental growth conditions. Seedlings were collected at 24 hours after PAMP application for aniline-blue staining and callose was quantified digitally by the relative number of fluorescent pixels under UV. To minimise possible bias from un-accounted environmental conditions, results are presented from experiments that showed consistent outcomes in three different laboratories. Results presented constitute a pooled dataset Increasing concentrations of sucrose in the growth medium had a general suppressive effect on callose deposition (Fig. 2a). Although 1\% and $2.5 \%$ sucrose did not have a profound impact on the level of basal callose deposition in mock-treated seedlings, addition of $5 \%$ sucrose to the growth medium suppressed basal callose deposition by 6 -fold compared to plants at $0 \%$ sucrose. Moreover, Flg22-induced callose was significantly repressed at 2.5 and $5 \%$ sucrose, whereas chitosan-induced callose was already repressed at $1 \%$ sucrose compared to plants that had been grown at $0 \%$ sucrose. Hence, sucrose represses basal and PAMP-induced callose. Next, we investigated the effects of light on callose deposition. Seedlings grown at the relatively low light intensity of 75 $\mu$ E.m-2.s-1 deposited significantly lower levels of basal and Flg22-induced callose than seedlings grown at $150 \mu$ E.m-2.s-1 (Fig. 2b), suggesting that light boosts basal and Flg22induced callose. Differences in light intensity did not statistically affect quantities of chitosan-induced callose (Fig. 2b). Finally, we examined the impact of vitamins in the growth medium. Gamborg vitamins are commonly used to supplement hydroponic plant cultivation media. Notably, this supplement consists of a mixture of potent anti-oxidant vitamins, such as myo-inositol, thiamine and nicotinic acid (Gamborg et al. 1968). Cultivation of seedlings in medium with Gamborg vitamins drastically suppressed basal, Flg22- and chitosan-induced callose (Fig. 2b), suggesting a positive role of ROS in callose regulation. The relative numbers of callose depositions followed behaved similarly in response to different growth conditions as the relative callose intensities that are presented in Fig. 2 (data not shown). Overall, these results demonstrate that environmental growth conditions in hydroponically grown Arabidopsis have a profound impact on the regulation of callose deposition.

Impact of growth conditions on hydrogen peroxide accumulation. Because antioxidant Gamborg vitamins suppressed basal and PAMP-induced callose (Fig.2b), we examined to what extent this variation is related to endogenous $\mathrm{H} 2 \mathrm{O} 2$ levels. To this end, seedlings were grown under different growth conditions and fixed in acidic 3,3diaminobenzidine $(\mathrm{DAB})$ staining solution $(\mathrm{pH}<3)$ at $24 \mathrm{~h}$ after PAMP treatment. $\mathrm{H} 2 \mathrm{O} 2$ levels were quantified digitally by the relative number of dark-brown pixels after $24 \mathrm{~h}$ of staining. Callose-suppressive growth conditions, such as low light $(75 \mu \mathrm{E} . \mathrm{m}-2 . \mathrm{s}-1), 5 \%$ sucrose, or the presence of Gamborg vitamins, suppressed basal and PAMP-induced $\mathrm{H} 2 \mathrm{O} 2$ (Fig. 3). Conversely, callose-promoting growth conditions, such as high light intensity (150 $\mu$ E.m-2.s-1), 1\% sucrose, or lack of vitamins (Fig. 2), allowed significantly higher levels of basal and PAMP-induced $\mathrm{H}_{2} \mathrm{O}_{2}$ (Fig. 3). Hence, the observed variation in callose deposition under different growth conditions correlates with levels of $\mathrm{H}_{2} \mathrm{O}_{2}$ accumulation in the tissue.

\section{Impact of growth conditions on hydrogen peroxide accumulation.}

Because anti-oxidant Gamborg vitamins suppressed basal and PAMP-induced 
callose (Fig.2b), we examined to what extent this variation is related to endogenous $\mathrm{H}_{2} \mathrm{O}_{2}$ levels. To this end, seedlings were grown under different growth conditions and fixed in acidic 3,3-diaminobenzidine (DAB) staining solution $(\mathrm{pH}<3)$ at $24 \mathrm{~h}$ after PAMP treatment. $\mathrm{H}_{2} \mathrm{O}_{2}$ levels were quantified digitally by the relative number of dark-brown pixels after $24 \mathrm{~h}$ of staining. Callose-suppressive growth conditions, such as low light (75 $\mu$ E.m-2.s-1), 5\% sucrose, or the presence of Gamborg vitamins, suppressed basal and PAMP-induced $\mathrm{H}_{2} \mathrm{O}_{2}$ (Fig. 3). Conversely, callose-promoting growth conditions, such as high light intensity (150 $\mu$ E.m-2.s-1), 1\% sucrose, or lack of vitamins (Fig. 2), allowed significantly higher levels of basal and PAMP-induced $\mathrm{H}_{2} \mathrm{O}_{2}$ (Fig. 3). Hence, the observed variation in callose deposition under different growth conditions correlates with levels of $\mathrm{H}_{2} \mathrm{O}_{2}$ accumulation in the tissue.

The impact of ABA on callose deposition varies according to the growth conditions.

The role of $\mathrm{ABA}$ as a regulatory hormone in disease resistance has been studied extensively (Asselbergh et al. 2008; Mauch-Mani and Mauch 2005; Ton et al. 2009). Nevertheless, the role of this plant hormone in regulation of pathogen-induced callose remains controversial. To examine in how far this controversy is related to influences by abiotic growth conditions, we examined the effects of ABA application on callose under different conditions. At low light intensity (75 $\mu$ E.m-2.s-1), 5\% sucrose and Gamborg vitamins, pre-treatment with $5 \mu \mathrm{M}$ ABA at 24 hours prior to PAMP application resulted in a repression of basal and PAMP-induced callose deposition (Fig. 4). Strikingly, when seedlings had been cultivated at high light intensity $(150 \mu$ E.m-2.s-1), $1 \%$ sucrose, and without vitamins, pre-treatment with ABA stimulated basal and PAMP-induced callose (Fig.4). Similarly contrasting effects were observed upon treatment with $50 \mu \mathrm{M}$ ABA (Table II).

To identify the exact growth conditions under which ABA represses or stimulates callose, we performed experiments under various combinations of light, sucrose and vitamins. Only the combination of low light intensity $(75 \mu \mathrm{E} . \mathrm{m}-2 . \mathrm{s}-1), 5 \%$ sucrose and Gamborg vitamins provided conditions under which ABA suppressed callose, whereas all other conditions supported mostly stimulatory effects by ABA (Table II). For all

\begin{tabular}{|c|c|c|c|c|c|}
\hline \multirow[b]{2}{*}{ Light intensity $^{\mathrm{a}}$} & \multirow[b]{2}{*}{ Sucrose $(\%)$} & \multirow[b]{2}{*}{ Gamborg vitamins } & \multicolumn{3}{|c|}{ Effect of ABA pretreatment ${ }^{b}$} \\
\hline & & & Mock & Flg22 & Chitosan \\
\hline High light & 1 & No & + & + & + \\
\hline Low light & 1 & No & + & + & n.s. \\
\hline High Light & 5 & No & n.s. & + & + \\
\hline Low light & 1 & Yes & + & + & + \\
\hline High light & 1 & Yes & n.s. & + & + \\
\hline Low light & 5 & Yes & - & - & - \\
\hline
\end{tabular}

Table 2: Impact of pretreatment with $50 \mu \mathrm{M}$ abscisic acid (ABA) on basal and pathogen-associated molecular pattern (PAMP)-induced callose at different growth conditions. 

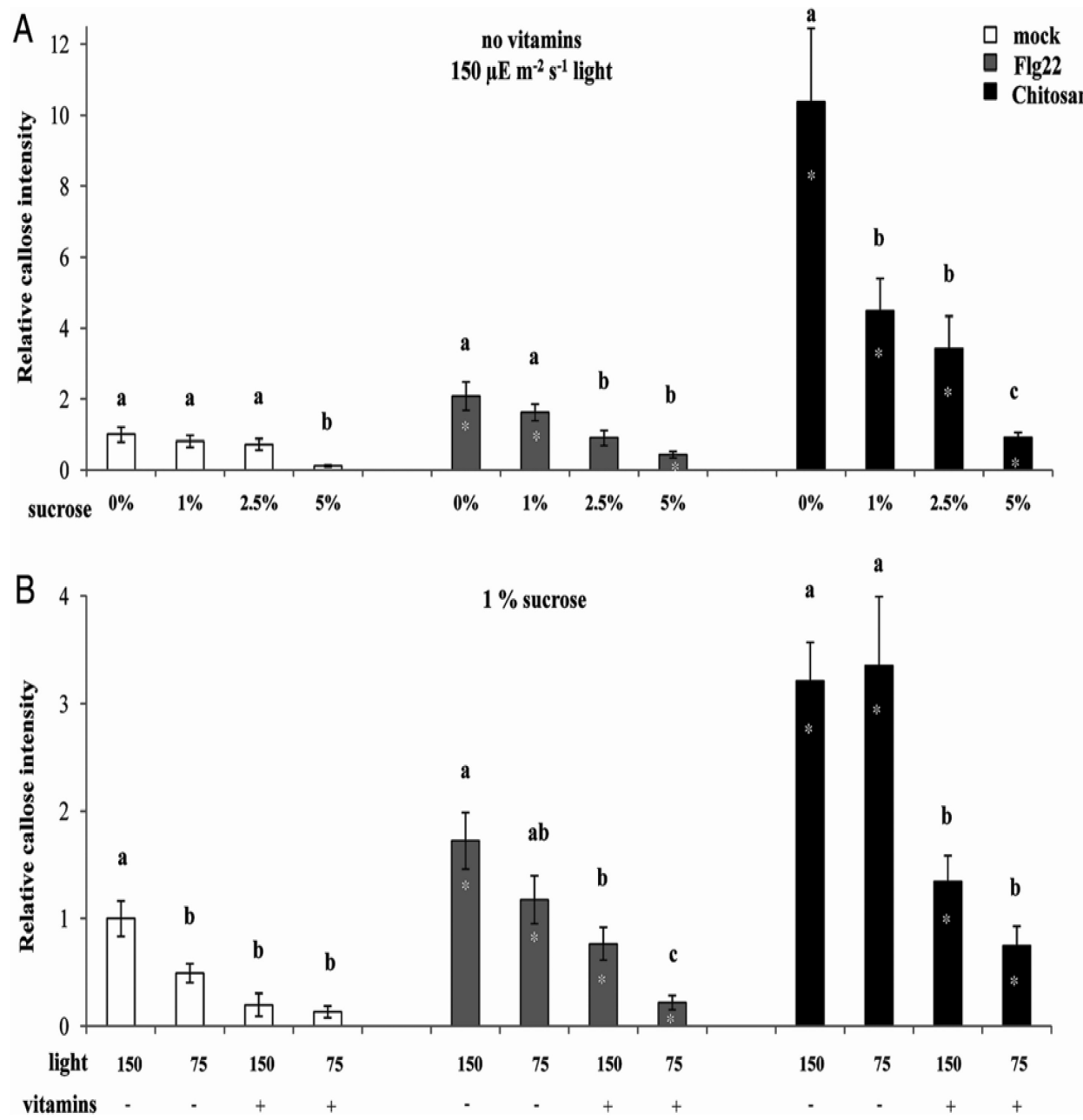

Figure 2: Impact of growth conditions on callose deposition in cotyledons of 9-day-old Arabidopsis seedlings (Col-0). Shown are average values of relative callose intensities $( \pm$ SEM; n $>20)$ at $24 \mathrm{~h}$ after treatment with $1 \mu \mathrm{M} \mathrm{Flg} 22$, or $0.01 \%$ chitosan. Values were standardised to the callose intensity in mock-treated seedlings at $150 \mu$ E.m-2.s-1 light, $1 \%$ sucrose and without Gamborg vitamins. Different letters indicate statistically significant differences between growth conditions (Fisher's LSD test; $\alpha=0.05$ ). Asterisks indicate statistically significant differences between PAMP treatments and corresponding controls at similar growth conditions (Student's t-test; $\alpha=0.05$ ). (a): Impact of sucrose on callose deposition (b): Impact of light and Gamborg vitamins on callose deposition.

experiments, relative numbers of callose depositions responded similarly to ABA as the relative callose intensities (data not shown). Since the combination of low light, high sucrose and vitamins suppresses $\mathrm{H}_{2} \mathrm{O}_{2}$ accumulation (Fig. 3), we propose that the impact of $\mathrm{ABA}$ on callose changes from repressive to stimulatory, depending on a threshold of cellular ROS.

\section{Timing and localization of Flg22- and chitosan-induced $\mathrm{H}_{2} \mathrm{O}_{2}$ and callose.}

To further investigate the role of ROS in PAMP-induced callose, we performed a time-series experiment to establish the dynamics of $\mathrm{H}_{2} \mathrm{O}_{2}$ accumulation in response to Flg22 
and chitosan. Seedlings were cultivated at callose- and $\mathrm{H}_{2} \mathrm{O}_{2}$-promoting growth conditions ( $1 \%$ sucrose, $150 \mu$ E.m-2.s- 1 light, no vitamins) and were fixed in acidic DAB staining solution at different time-points after PAMP induction. Both Flg22 and chitosan induced $\mathrm{H}_{2} \mathrm{O}_{2}$ strongly at 30 minutes after application (Fig. 5a). However, Flg22-induced $\mathrm{H}_{2} \mathrm{O}_{2}$ was more transient than chitosan-induced $\mathrm{H}_{2} \mathrm{O}_{2}$, whereas chitosan-induced $\mathrm{H}_{2} \mathrm{O}_{2}$ was more sustained and lasted up to 24 hours after induction treatment. In a separate experiment, we

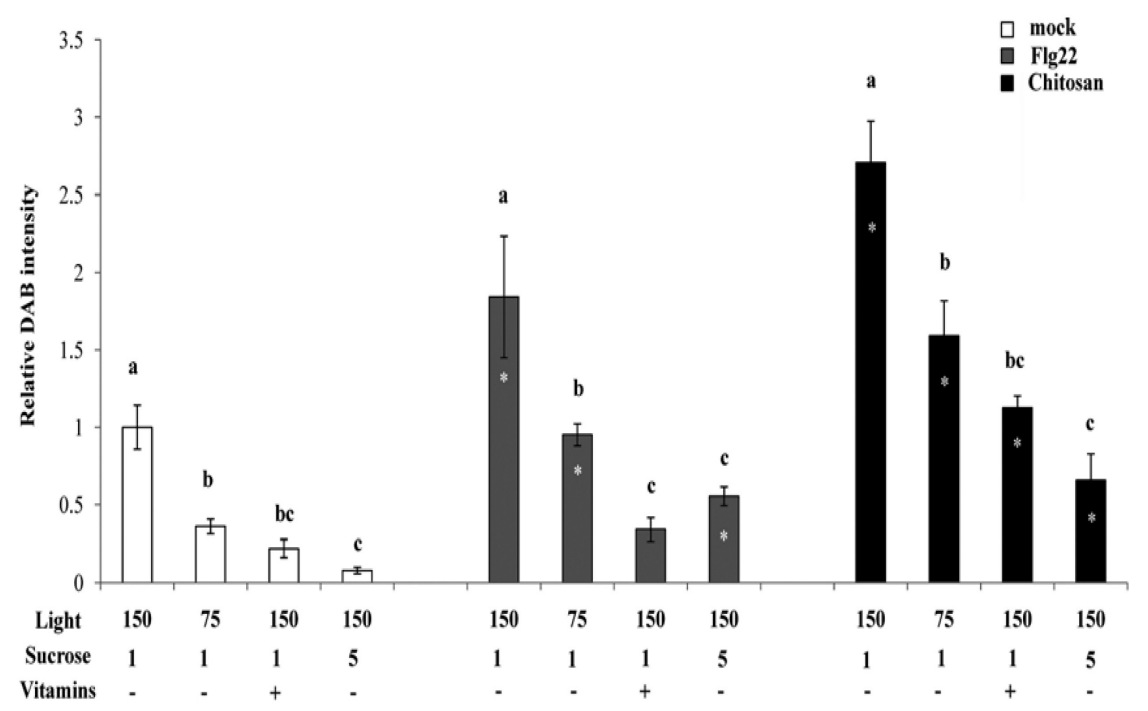

Figure 3: Impact of growth conditions on $\mathrm{H}_{2} \mathrm{O}_{2}$ accumulation in cotyledons of 9-day-old Arabidopsis seedlings. Shown are average values of relative DAB staining intensities $( \pm$ SEM; $n>15)$ at $24 \mathrm{~h}$ after treatment with $1 \mu \mathrm{M} \mathrm{Flg} 22$, or $0.01 \%$ chitosan. Values were standardised to the DAB intensity in mock-treated seedlings at $150 \mu$ E.m-2.s-1 light, $1 \%$ sucrose and without Gamborg vitamins. For details about statistical significance between growth conditions and PAMP treatments, see legend of Fig. 1.

assessed the dynamics of callose deposition under similar growth conditions. Also here, the dynamics of the callose response differed considerably between both PAMP treatments: whereas chitosan-induced callose was already apparent at 2 hours after treatment, Flg22induced callose was not significantly apparent until 8 hours after treatment (Fig. 5b). Hence, Flg22- and chitosan-induced callose are both preceded by $\mathrm{H}_{2} \mathrm{O}_{2}$ accumulation, but the dynamics of both PAMP responses differs between Flg22- and chitosan-treated seedlings.

To examine tissue localisation of PAMP-induced $\mathrm{H}_{2} \mathrm{O}_{2}$ and callose, seedlings were double-stained with $\mathrm{DAB}$ and aniline blue and examined by a combination of light and epifluorence microscopy (UV). Chitosan-induced $\mathrm{H}_{2} \mathrm{O}_{2}$ accumulated at similar sites as chitosan-induced callose (Fig. 5). On the other hand, no obvious co-localisation between $\mathrm{H}_{2} \mathrm{O}_{2}$ and callose was observed after treatment with Flg22. This lack of co-localisation may be caused by the more transient nature of Flg22-induced $\mathrm{H}_{2} \mathrm{O}_{2}$ accumulation (Fig. 6). Next, we investigated the sensitivity by which different plant tissues deposit PAMP-induced callose in the hydroponic growth medium. Millet et al. (2010) recently reported that Flg22, chitin and peptidoglycan trigger different patterns of callose deposition in roots of hydroponically growth Arabidopsis seedlings. Surprisingly, however, we did not find a significant increase in root callose deposition upon treatment with Flg22, while chitosan triggered a strong and statistically significant root callose response (Fig. 7). This differential 
responsiveness was consistent at different concentrations of applied PAMPs (Fig. 7). Since the Flg22 receptor FLS2 has been shown to be expressed in Arabidopsis roots (Robatzek et al. 2006), the differential callose response to Flg22 and chitosan can only be explained by dissimilarities in the downstream signalling pathways under our growth conditions. Together with differences in co-localisation between Flg22- and chitosan-induced $\mathrm{H}_{2} \mathrm{O}_{2}$ and callose (Fig. 6), these results suggest that Flg22- and chitosan-induced callose are controlled by distinct pathways.

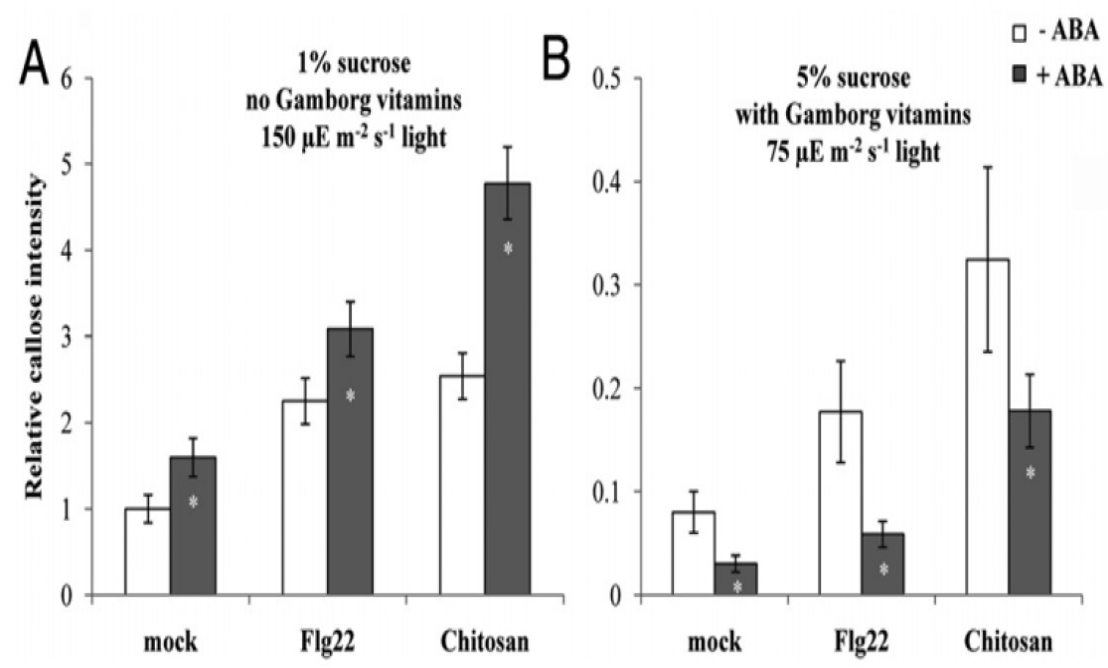

Figure 4: Opposite impacts of ABA on callose deposition at two different growth conditions. Seedlings were treated with $5 \mu \mathrm{M} \mathrm{ABA}$ at $24 \mathrm{~h}$ prior to PAMP treatment. Shown are average values of relative callose intensities $( \pm$ SEM; $n>20)$ at $24 \mathrm{~h}$ after PAMP treatment. Values were standardised to the callose intensity in mock-treated seedlings at $150 \mu$ E.m-2.s-1 light, $1 \%$ sucrose, without Gamborg vitamins and ABA. Asterisks indicate statistically significant changes in response to ABA treatment (Student's t-test; $\alpha=0.05$ ).
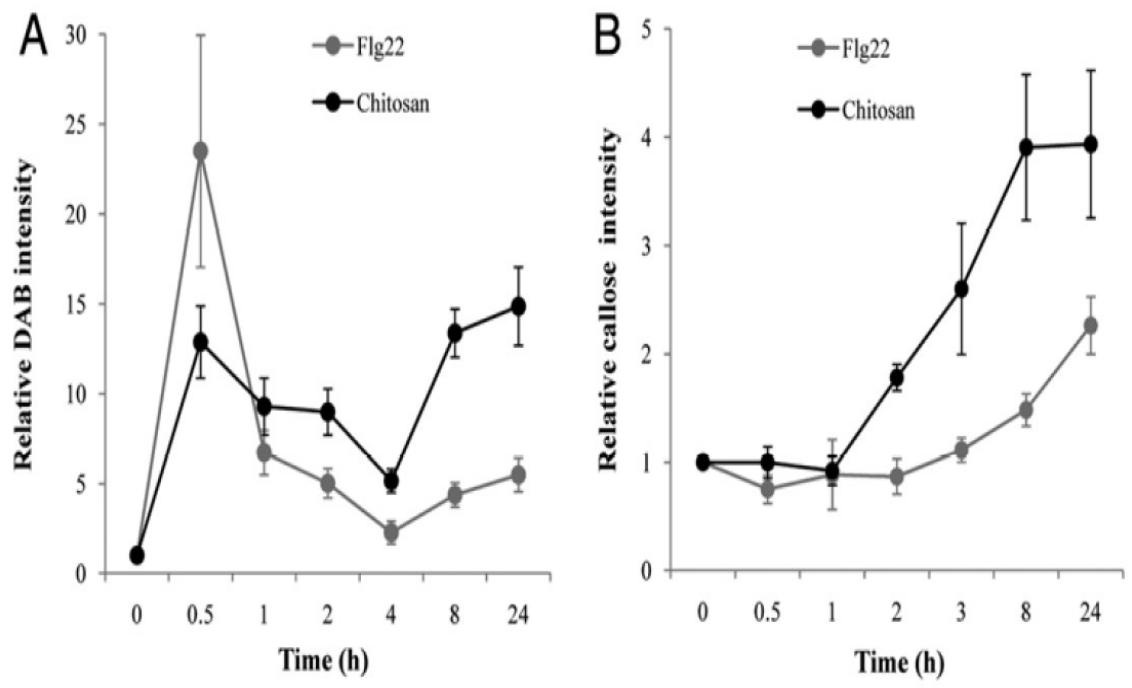

Figure 5: Dynamics of $\mathrm{H}_{2} \mathrm{O}_{2}$ (a) and callose (b) deposition at different time-points after treatment with $1 \mu$ M Flg22, or $0.01 \%$ chitosan. Shown are average values $( \pm S E M ; n>15$ ) of relative staining intensities standardised to mock treatments. Seedlings were grown under standard growth conditions at $150 \mu$ E.m-2.s-1 light, $1 \%$ sucrose and without Gamborg vitamins. 

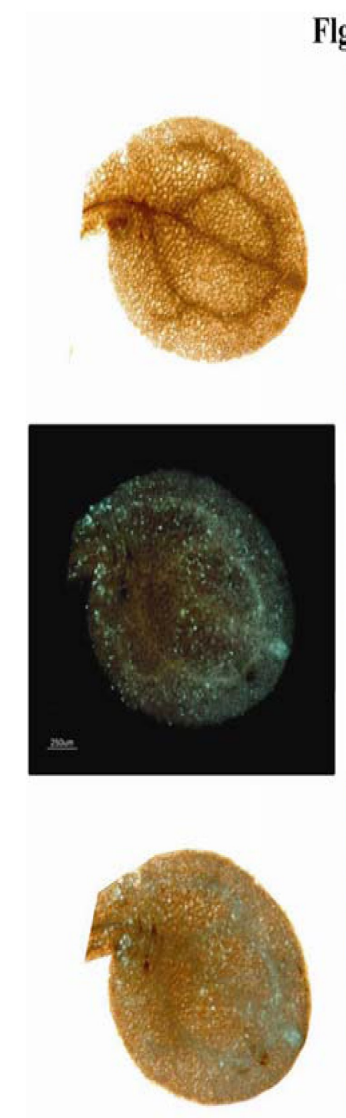

Flg22
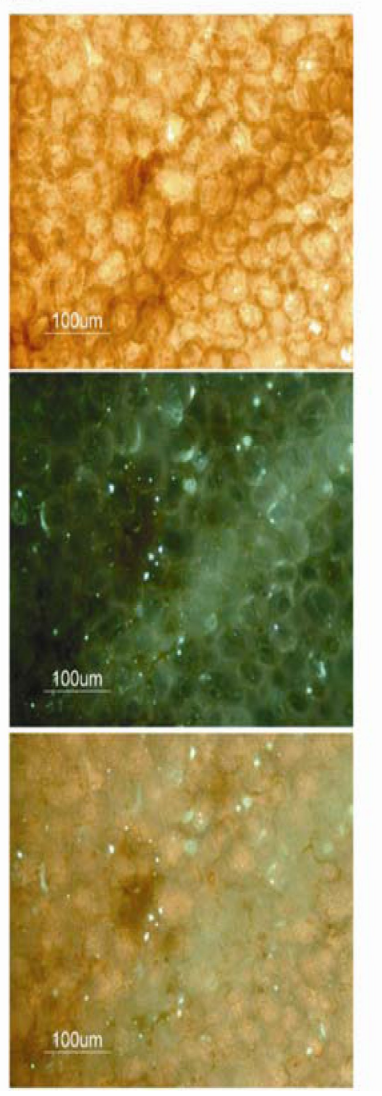

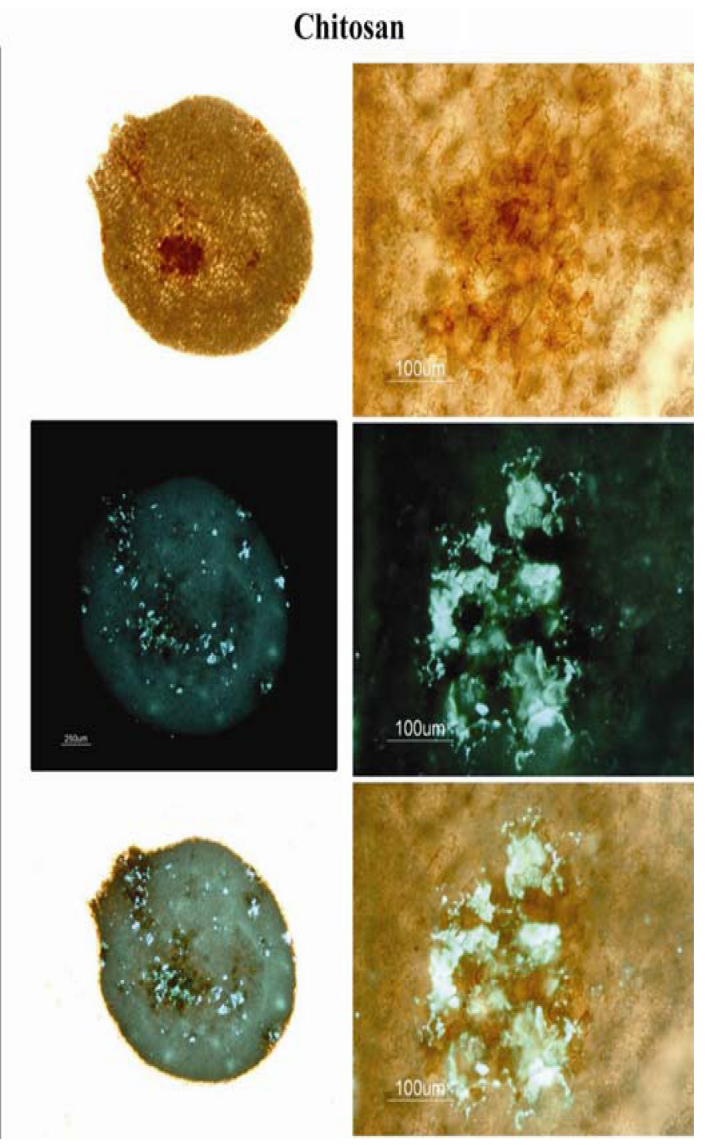

Figure 6: Localisation of $\mathrm{H}_{2} \mathrm{O}_{2}$ and callose at $24 \mathrm{~h}$ after treatment with $1 \mu \mathrm{M}$ Flg22, or $0.01 \%$

chitosan. Photographs show double-stained cotyledons (DAB and aniline-blue) exposed to a combination of bright light and UV. Seedlings were grown under standard conditions (see legend of Fig. 4).

\section{Differential regulation of Flg22- and chitosan-induced callose.}

To further investigate the pathways controlling Flg22- and chitosan-induced callose, we evaluated levels of PAMP-induced $\mathrm{H}_{2} \mathrm{O}_{2}$ and callose in mutants affected in ROSscavenging and ROS-producing enzymes. The cat2-1 mutant, which is impaired in a peroxisomal catalase (Bueso et al. 2007), allowed significantly enhanced levels of PAMPinduced $\mathrm{H}_{2} \mathrm{O}_{2}$ (Fig. 8a), which correlated with enhanced levels of callose deposition (Fig. $8 b)$. This phenotype is consistent with a potentiating function of $\mathrm{H}_{2} \mathrm{O}_{2}$ in callose deposition, since the cat2-1 mutant is reduced in its ability to scavenge $\mathrm{H} 2 \mathrm{O} 2$ (Bueso et al. 2007). In support of this, the rbohD mutant, carrying a T-DNA knock-out mutation in the superoxidegenerating NADPH oxidase gene $R B O H D$ (Pogany et al. 2009), produced strongly reduced levels of Flg22-induced $\mathrm{H}_{2} \mathrm{O}_{2}$ and failed to deposit enhanced levels of callose upon treatment with Flg22 (Fig. 8). Surprisingly, however, rbohD deposited wild-type levels of callose in response to chitosan (Fig. 8b), despite an obvious reduction in chitosan-induced $\mathrm{H}_{2} \mathrm{O}_{2}$ (Fig. 8a). Thus, chitosan-induced callose, unlike Flg22-induced callose, does not require RBOHD-dependent $\mathrm{H}_{2} \mathrm{O}_{2}$. The vtcl-1 mutant, which accumulates 10-fold lower 
levels of antioxidant ascorbic acid than wild-type plants (Conklin et al. 2000), displayed differential responsiveness to Flg22 and chitosan as well. The vtc1-1 mutant allowed dramatically enhanced levels of $\mathrm{H}_{2} \mathrm{O}_{2}$ under all conditions tested (Fig. 7a) and showed augmented levels of basal and chitosan-induced callose in comparison to wild-type plants (Fig. 8b). However, vtcl-1 failed to deposit increased levels of callose after treatment with Flg22 (Fig. 8b). Since ascorbic acid functions as a co-factor in myrosinase-dependent breakdown of glucosinolates (Burmeister et al. 2000), the inability of vtcl-1 to deposit enhanced callose upon Flg22 treatment confirms the earlier finding that glucosinolate metabolites regulate Flg22-induced callose (Clay et al. 2009). Accordingly, basal and chitosan-induced callose is not controlled by glucosinolate-derived metabolites.

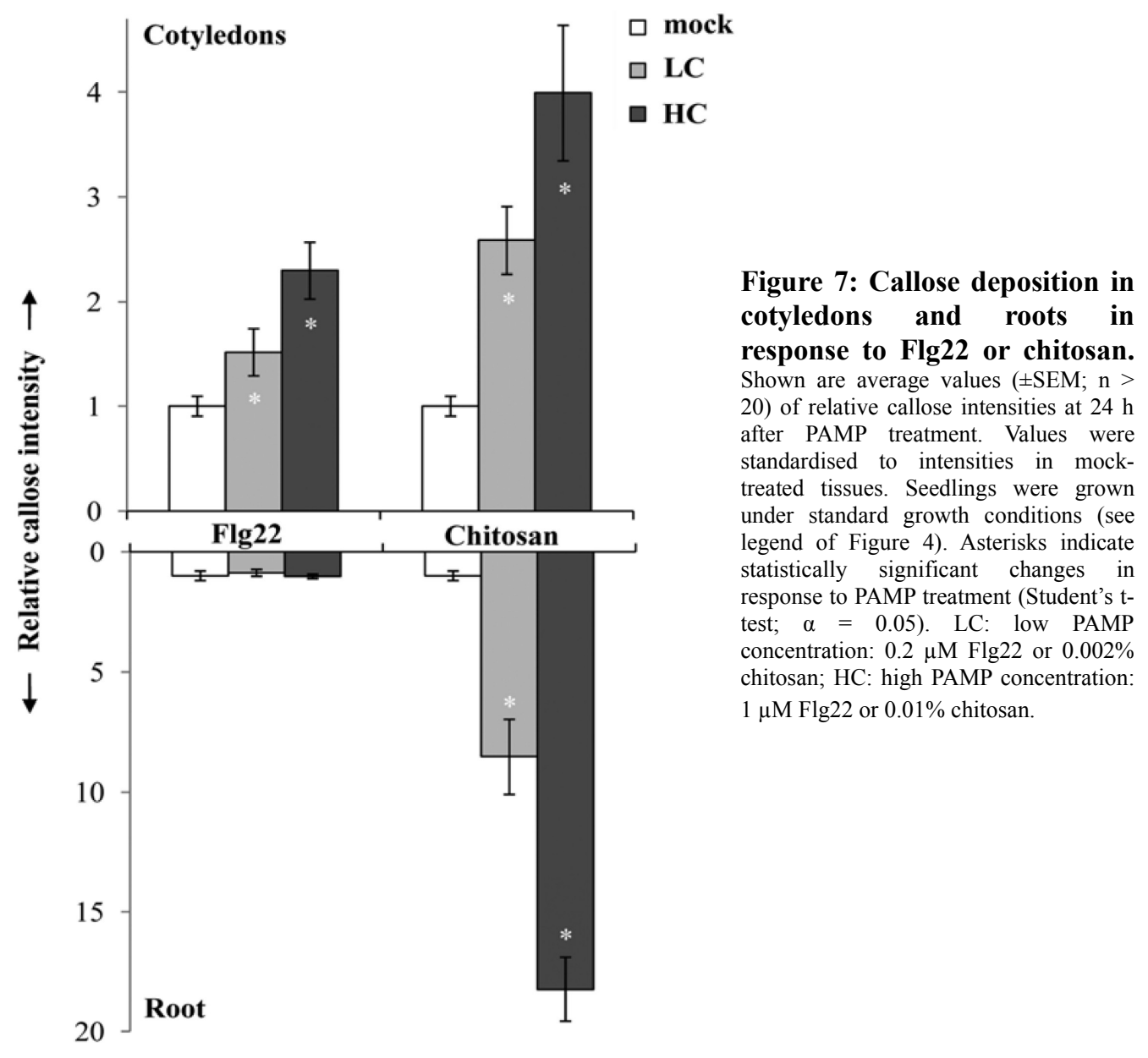

To clarify the role of glucosinolate metabolites in callose deposition, we tested the myrosinase mutant pen2-2, which is blocked in production of specific glucosinolate breakdown products (Bednarek et al. 2009; Clay et al. 2009). Unlike the vtc1-1 mutant, pen2-2 deposited wild-type levels of basal callose and $\mathrm{H}_{2} \mathrm{O}_{2}$ (Fig.8). However, pen2-2 failed to deposit enhanced callose in response to Flg22 (Fig. 8b), despite wild-type levels of Flg22- 
induced $\mathrm{H}_{2} \mathrm{O}_{2}$ in this mutant (Fig. 8a). Treatment of pen2-2 with chitosan, on the other hand, resulted in wild-type levels of callose and $\mathrm{H}_{2} \mathrm{O}_{2}$ deposition (Fig. 8). Hence, glucosinolate metabolites play a role in Flg22-induced callose, but play no role in chitosan-induced callose deposition.

To examine the contribution of the callose synthase PMR4, we quantified levels of Flg22- and chitosan-induced callose in the pmr4-1 mutant (Nishimura et al. 2003). As expected, pmr4-1 deposited dramatically reduced levels of basal callose and failed to respond to Flg22 (Fig. 9). However, chitosan elicited a residual callose response in pmr4-1 plants, even though the absolute levels of chitosan-induced callose were reduced by $90 \%$ in comparison to the wild-type (Fig. 9). Thus, Flg22-induced callose is entirely derived from PMR4, while approximately $10 \%$ of chitosan-induced callose comes from other callose synthase(s) than PMR4.

\section{DISCUSSION}

The primary objective of this study was to evaluate the robustness and reproducibility of a widely used model system in PTI plant research: PAMP-induced callose in cotyledons of hydroponically grown Arabidopsis seedlings. Although exogenous application of Flg22 or chitosan consistently boosted callose elicitation, overall callose production varied according to the growth conditions. This environmental variability affected both basal callose deposition in mock-treated plants, and PAMP-induced callose in Flg22- and chitosan-treated plants. Hence, the environmental growth conditions do not specifically act on the responsiveness to one certain PAMP, but rather affect the plant's overall capacity to deposit callose (Figs. 2 and 3). Remarkably, pre-treatment with the environmental response hormone ABA had opposite effects on callose production, depending on the environmental growth conditions (Fig. 4). These results not only provide an explanation for the controversial role of ABA in callose defence (Ton et al. 2009), but they also complicate the interpretation of callose deposition as a uniform defence marker of PTI signalling. In support of that conclusion, we furthermore found that the pathways controlling Flg22- and chitosan-induced callose differ in their requirement for various signal transduction components.

Hence, the model system of PAMP-induced callose in hydroponically grown Arabidopsis involves regulation by more than one pathway, which differs according to the environmental conditions and the eliciting PAMP. This outcome warrants extra caution with generalisations regarding PTI signalling on the basis of this model system. Anti-oxidant vitamins suppressed callose deposition, whereas light intensity stimulated callose deposition (Fig. 2). The accumulation of $\mathrm{H} 2 \mathrm{O} 2$ displayed remarkably similar patterns of variation at these growth conditions (Fig. 3), suggesting that the environmental variability in callose deposition is caused by fluctuations in ROS. In this context, the callose-promoting effects by exogenously applied ABA (Fig. 4; Table II) can be explained by ABA-induced ROS (Ghassemian et al. 2008; Xing et al. 2008). Conversely, the observed suppression of callose by sucrose (Fig. 2) can be explained by repression of photosynthesis activity and related ROS (Paul and Driscoll 1997; Sheen 1990). Two recent studies identified five PTI signalling components on the basis of a mutant screen in Elf18-induced repression of anthocyanins at high sucrose, demonstrating that the negative cross-talk between sucrose and PTI signalling 
acts in two directions (Lu et al. 2009; Saijo et al. 2009). All five "PRIORITIRY IN SWEET $L I F E$ " genes (PSL) derived from this mutant screen encode components in endoplasmatic reticulum-localised $\mathrm{N}$-glycosylation, which regulates quality control and stable expression of the Elf18 receptor EFR. Interestingly, however, the psl mutants were unaffected in stability and functioning of the Flg22 receptor FLS2 (Lu et al. 2009; Saijo et al. 2009), demonstrating that the

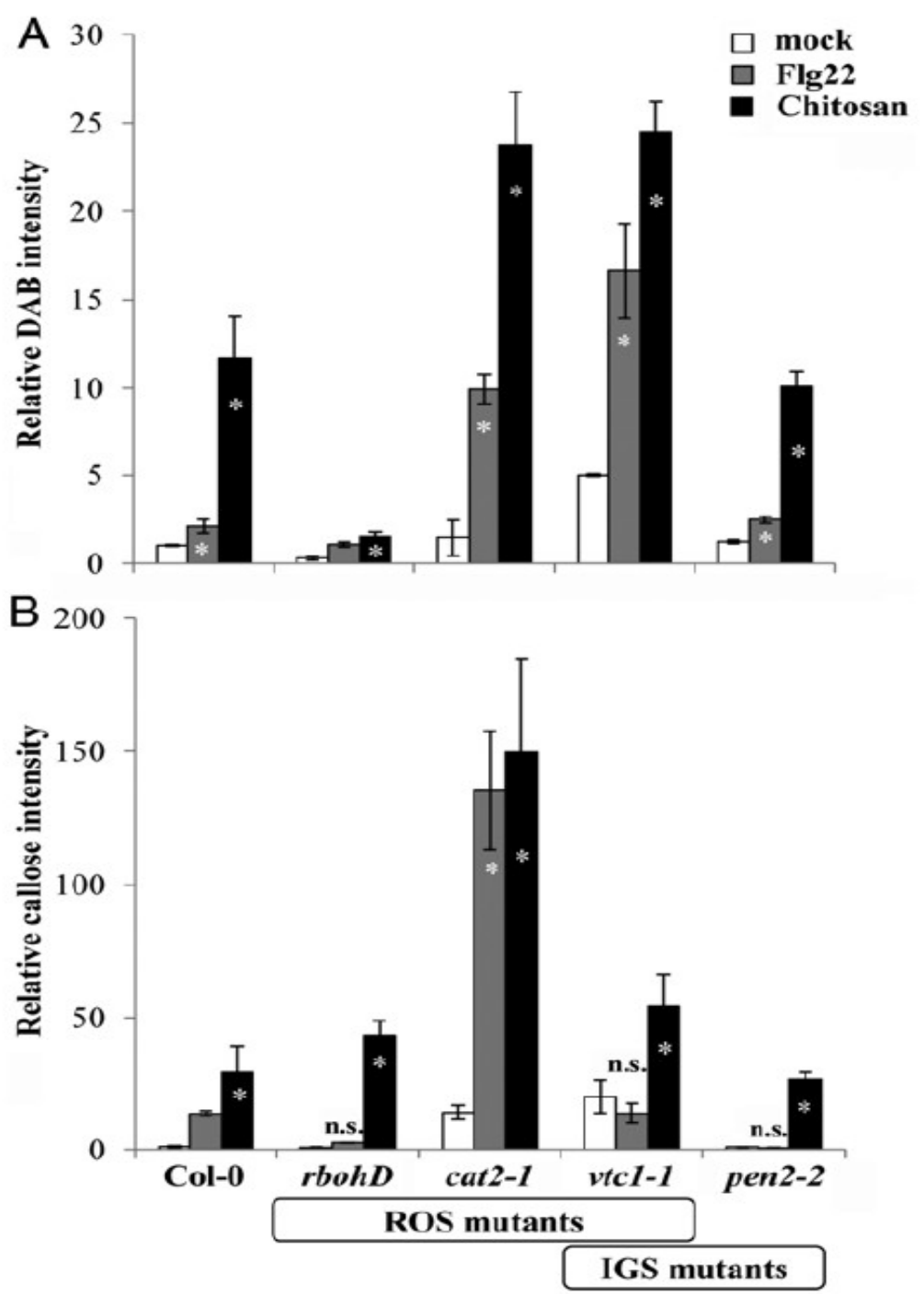

Figura 8: Effect of mutations in homeostasis of reactive oxygen species (ROS) and biosynthesis of indolytic glucosinolates (IGS) on $\mathrm{H}_{2} \mathrm{O}_{2}$ (a) and callose (b) deposition upon treatment with $1 \mu \mathrm{M}$ Flg22, or $0.01 \%$ chitosan. Shown are average values ( \pm SEM; $n>15)$ of relative staining intensities. Values were standardised to staining intensities in mock-treated wild-type seedlings (Col-0). Seedlings were grown under standard growth conditions (see legend of Figure 4). Asterisks indicate statistically significant changes in response to PAMP treatment within each genotype (Student's t-test; $\alpha=0.05$ ). 


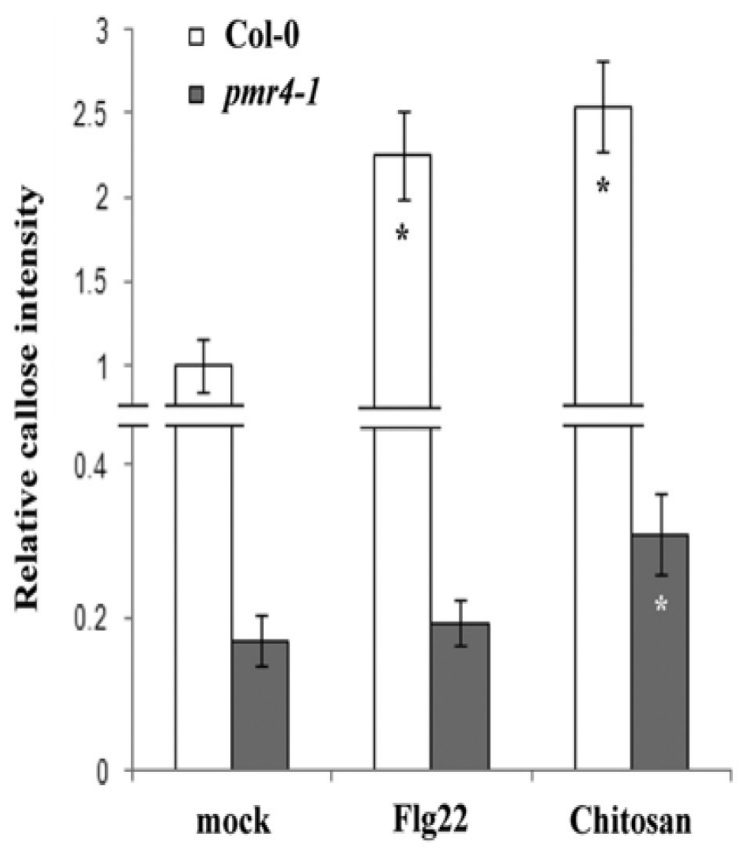

Figure 9: Callose deposition in wild-type (Col-0) and pmr4-1 seedlings at $24 \mathrm{~h}$ after treatment with $1 \mu \mathrm{M}$ Flg22, or $0.01 \%$ chitosan. For further details, see legend of Fig. 7.

involvement of $\mathrm{N}$-glycosylation in PTI signalling is PAMP-specific (Haweker et al. 2010; Saijo 2010). In this study, we demonstrated a PAMP-specific contribution of signalling components further downstream in PTI signalling, such as AtRBOHD, glucosinolate metabolites and even the callose synthase PMR4 (Fig. 8,9). Considering that single pathogen species produce multiple PAMP signals, we conclude that callose deposition in response to pathogen infection is regulated by multiple signalling pathways, rather than one conserved downstream pathway.

The contrasting effects of $\mathrm{ABA}$ on callose regulation under different growth conditions point to a complex interplay between environmental response pathways. In our experiments, ABA repressed basal and PAMP-induced callose at low light intensity, high sucrose concentration and vitamins (Fig. 4), whereas all other conditions supported predominantly stimulatory effects by ABA (Fig. 4; Table II). Previously, it was shown that ABA represses Flg22-induced callose in hydroponic Arabidopsis under nearly identical growth conditions (Clay et al. 2009), except for the concentration of sucrose in the growth medium (0.5\%; Clay et al. 2009; corrected at 31 July 2009 - Materials and Methods). This ABA-mediated suppression of callose was explained by ABA-induced repression of the ethylene-inducible transcription factor MYB51, which regulates biosynthesis of indolytic glucosinolates (Gigolashvili et al. 2007). However, this cross-talk mechanism does not explain why ABA stimulates callose under other growth conditions. Interestingly, the specific growth conditions that supported ABA-induced priming of callose deposition also allowed for enhanced accumulation of $\mathrm{H} 2 \mathrm{O} 2$ in the tissue (Fig. 3, 4). Furthermore, 
exogenous application of $\mathrm{ABA}$ has been demonstrated to trigger $\mathrm{H} 2 \mathrm{O} 2$ accumulation in Arabidopsis (Xing et al. 2008). We, therefore, propose that environmental growth conditions can boost ABA-induced ROS to a threshold that promotes callose, thereby masking/bypassing ABA-induced suppression of MYB51-dependent callose.

The analysis of Arabidopsis signalling mutants revealed that the cat2-1 mutant accumulates significantly enhanced levels of $\mathrm{H} 2 \mathrm{O} 2$ and callose after treatment with Flg22 or chitosan (Fig. 8). Considering that cat2-1 is impaired in a peroxisomal catalase (Bueso et al. 2007), this mutant phenotype suggests a potentiating role of $\mathrm{H} 2 \mathrm{O} 2$ in both Flg22- and chitosan-induced callose. We furthermore found that the rbohD mutant is blocked in Flg22-induced callose, but not in chitosan-induced callose (Fig. 8b), whereas both Flg22- and chitosan-induced $\mathrm{H} 2 \mathrm{O} 2$ were dramatically reduced in this mutant (Fig. 8a). Hence, chitosan-induced callose does not require $\mathrm{H} 2 \mathrm{O} 2$ from the NADPH oxidase RBOHD. Furthermore, $r b o h D$ seedlings still showed a statistically significant increase in $\mathrm{H} 2 \mathrm{O} 2$ after PAMP treatment, despite the obvious reduction in absolute $\mathrm{H} 2 \mathrm{O} 2$ levels compared to wildtype plants. This demonstrates that PAMP-induced $\mathrm{H} 2 \mathrm{O} 2$ is only partially derived from RBOHD. Consequently, we propose that Flg22-induced callose, like OG-induced callose (Galletti et al. 2008), is controlled by RBOHD-dependent H2O2, whereas chitosan-induced callose is controlled by RBOHD-independent $\mathrm{H} 2 \mathrm{O} 2$. Additional evidence for differential regulation of Flg22- and chitosan-induced callose comes from the behaviour of the pen2-2 and vtcl-1 mutants. Both mutants were blocked in Flg22-induced callose, but were unaffected in chitosan-induced callose (Fig. 8). Given the role of PEN2 and VTC1 in the hydrolysis of glucosinolates (Bednarek et al. 2009; Burmeister et al. 2000; Clay et al. 2009), we support the conclusion that Flg22-induced callose is regulated by glucosinolate-derived metabolites. However, these metabolites are apparently not involved in the regulation of chitosan-induced callose.

Chitosan has long been known for its defence-eliciting capacities in plants, even though the nature and intensity of the chitosan-induced plant defence response differs according to its physiochemical characteristics, such as degree of de-acytelation, viscosity, and molecular weight (Iritri and Faoro 2009). In this study, we have used low-viscous chitosan with a molecular weight of $\sim 150 \mathrm{kD}$ and a $95-98 \%$ degree of acetylation (Hombach and Bernkop-Schnürch 2009). The only mutation that significantly reduced chitosan-induced callose was the pmr4-1 mutation (Fig. 9). Conversely, mutations affecting the plant's ROS-scavenging ability, such as cat2-1 and vtc1-1, consistently augmented chitosan-induced callose (Fig. 8). Furthermore, both Flg22- and chitosan-induced callose were consistently higher under environmental growth conditions that allowed for higher levels of ROS accumulation (Fig. 2, 3). Hence, despite the specific differences between the pathways controlling Flg22- and chitosan-induced callose, ROS seem to have a general potentiating effect on PAMP-induced callose.

The Flg22 response of Arabidopsis has emerged as a model of PTI signalling. Recognition of Flg22 triggers a rapid mitogen-activated protein kinase (MAPK) cascade involving the defence regulatory kinases MPK3 and MPK6 (Asai et al. 2002; SuarezRodriguez et al. 2007), which can be suppressed by virulence-promoting pathogen effectors (He et al. 2006; Zhang et al. 2007). This MPK3/MPK6-dependent MAPK cascade activates downstream WRKY transcription factors, which promote transcription of early-acting defence genes (Asai et al. 2002; Navarro et al. 2004). In addition, this MAPK cascade stimulates generation of RBOHD-dependent ROS, which subsequently promote deposition 
of PMR4-dependent callose (He et al. 2006; Zhang et al. 2007). The recent discovery that glucosinolate metabolites regulate Flg22-induced callose adds a novel layer to signalling pathways controlling this PTI response (Clay et al. 2009). Given the toxic nature of glucosinolate break-down products (Halkier and Gershenzon 2006), their function in callose deposition may be explained as part of a cellular detoxification response, which mediates secretion of these defence metabolites into the apoplast, where they are captured in callosecontaining papillae. Accordingly, glucosinolate metabolites act at relatively late stages of the Flg22-induced pathway. In support of this, we found that vtc1-1 and pen2-2 are not reduced in Flg22-induced $\mathrm{H}_{2} \mathrm{O}_{2}$, suggesting that glucosinolate metabolites act downstream of RBOHD-generated $\mathrm{H}_{2} \mathrm{O}_{2}$ in the regulation of Flg22-induced callose.

Unlike other studies, our experiments revealed relatively high basal levels of callose in the mock treatments. Apart from differences in growth conditions, this discrepancy could be related to a difference in staining technique. Whereas our experiments used ethanol for the de-staining of chlorophyll, other studies commonly use ethanol followed by $10 \% \mathrm{NaOH}$ for this purpose (Clay et al. 2009; Millet et al. 2010). It is possible that incubation in such strongly alkaline solution removes or eradicates part of the callose that is present at the cell wall, thereby lowering the detection limit of callose and giving the impression that cotyledons from mock-treated plants contain no callose. Another surprising outcome was the lack of Flg22-induced callose in roots, which contradicts a recent report by Millet et al. (2010), who demonstrated that Flg22-induced callose in Arabidopsis roots depends on a similar pathway as Flg22-induced callose in cotyledons (Clay et al., 2009). It seems difficult to envisage that our staining method fails to detect Flg22-induced callose in the roots, while it was 2009). It seems, therefore, more plausible that this discrepancy originates from differences in growth conditions. Whereas Millet et al. (2010) cultivated seedlings in MS medium with vitamins at a light intensity $100 \mu \mathrm{E} . \mathrm{m}-2 . \mathrm{s}-1$, we cultivated the seedlings in medium without vitamins at $150 \mu$ E.m-2.s-1 light. Since higher levels of light and lack of vitamins allow for significantly higher levels of basal ROS and callose accumulation (Fig. $2 \mathrm{~b}, 3$ ), we propose that Flg22-induced callose in roots was masked by relatively high basal levels of callose deposition under our experimental conditions.

In summary, our study uncovered an un-expectedly large degree of environmental variation in PAMP-induced callose deposition of hydroponically grown Arabidopsis. Worryingly, this model system seems relatively standardised and designed to minimise experimental variation. It can, therefore, be expected that fluctuations in environmental growth conditions have even bigger impacts on PTI signalling during more complex interactions, such as those between soil-grown plants, pathogenic microbes and/or plantbeneficial microbes. This could also explain previously reported controversy about the involvement of plant hormones in plant-microbe interactions (Beckers and Spoel 2006; Robert-Seilaniantz et al. 2007; Ton et al. 2009), as well as inconsistencies in complex plantmicrobe assays. Above all, our study warrants for extra caution with generalisations regarding plant innate immunity on the basis of callose deposition in hydroponically grown Arabidopsis seedlings. 


\section{Materials and methods}

\section{Plant material, growth conditions and chemical treatments.}

Seeds of Arabidopsis thaliana accession Col-0 and mutants in this background [pmr4-1 (Nishimura et al. 2003), vtc1-1 (Conklin et al. 2000), cat2-1 (Bueso et al. 2007), pen2-2 (Lipka et al. 2005), and rbohD (Pogany et al. 2009)] were vapour-phase sterilised for 4 to $6 \mathrm{~h}$ (http://entomology.wisc.edu/ afb/vapster.html). Approximately 15 seeds per well were planted in sterile 12-well plates, each containing $1 \mathrm{~mL}$ filter-sterilised basal Murashige and Skoog (MS) medium with or without Gamborg vitamins (Sigma; containing $100 \mu \mathrm{g} / \mathrm{L}$ myo-inositol, $1 \mu \mathrm{g} / \mathrm{L}$ nicotinic acid, $1 \mu \mathrm{g} / \mathrm{L}$ pyridoxine hydrochloride, and $10 \mu \mathrm{g} / \mathrm{L}$ thiamine hydrochloride) with varying concentrations of sucrose $(0 \%, 1 \%, 2.5 \%$ and $5 \%)$. All growth media were supplemented with $0.5 \%$ MES hydrate (final $\mathrm{pH}$ : 5.7 - 5.8). Plates were kept in the dark at $4{ }^{\circ} \mathrm{C}$ for $1-2$ days before transferring to controlled growth cabinets. Seedlings were cultivated under standard growth conditions $\left(16 \mathrm{~h} / 8 \mathrm{~h}\right.$ day/night cycle; $\left.20^{\circ} \mathrm{C} / 17^{\circ} \mathrm{C}\right)$ at two different light intensities ( 75 and $150 \mu \mathrm{E} . \mathrm{m}-2 . \mathrm{s}-1)$. At 7 days of growth, MS medium was replaced with fresh medium. ABA was applied at day 8 to a final concentration to 5 or $50 \mu \mathrm{M}$. At day 9, seedlings were challenged with $1 \mu \mathrm{M}$ Flg22 (GenScript; applied as $10 \mu \mathrm{L}$ $100 \mu \mathrm{M}$ Flg22 solution) or $0.01 \%$ (w/v) low-viscous chitosan (Fluka; applied as $10 \mu \mathrm{L} \mathrm{1 \%}$ chitosan (v/w) solution in $1 \%$ acetic acid), which has a molecular weight of $\sim 150 \mathrm{kD}$ and a $95-99-8 \%$ degree of acetylation (Hombach and Bernkop-Schnürch 2009). These PAMP concentrations were based on previously reported dose-response experiments (Flg22: Gomez-Gomez et al. 1999b; chitosan: Iriti et al. 2006), as well as the consistency in callose response between independent experiments (data not shown). Mock treatments were performed by addition of $10 \mu \mathrm{L}$ water to the growth medium. Addition of $10 \mu \mathrm{L} 1 \%$ acetic acid did not change the $\mathrm{pH}$, nor influence callose deposition in mock- or Flg22-treated plants (data not shown). Experiments to examine callose deposition under different growth and ABA conditions were performed at three different laboratories: at Rothamsted Research, UK, at the University of Jaume I of Castellón, Spain, and at the University of Neuchâtel, Switzerland (for further details see Table SI).

\section{Aniline blue staining, microscopy analysis and callose quantification.}

Seedlings were collected, de-stained in $95 \% \mathrm{EtOH}$ and stained with aniline-blue as described previously with some modification (Ton et al. 2005). Briefly, seedlings were incubated for at least $24 \mathrm{~h}$ in $95-100 \%$ ethanol until all tissues were transparent, washed in $0.07 \mathrm{M}$ phosphate buffer $(\mathrm{pH}=9)$, and incubated for $1-2 \mathrm{~h}$ in $0.07 \mathrm{M}$ phosphate buffer containing $0.01 \%$ aniline-blue (Sigma) prior to microscopic analysis. Observations were performed with an epifluorescence microscope with UV filter (BP 340-380 nm, LP $425 \mathrm{~nm}$ ). Callose was quantified from digital photographs by the number of white pixels, (callose intensity) relative to the total amount of pixels corresponding to plant material, using Photoshop CS3 software (Fig. S2). Contrast settings of the photographs were adjusted to obtain an optimal separation of the callose signal from the background signal. Callose was selected either manually, by using the "Magic Wand" tool of Photoshop CS3, or automatically, by using the "Colour Range" tool. The resulting callose selection was visually verified for accuracy before proceeding. Numbers of depositions and callosecorresponding pixels were recorded as number of measurements and area covered by the total number of selected pixels, respectively, using the "Record Measurements" tool of 
Photoshop CS3. Average callose measurements were based on at least 20 photographs from different seedlings and analysed for statistical differences by Student's t-tests or ANOVA following by Fisher's LSD tests $(n=20-40 ; \alpha=0.05)$.

\section{DAB staining, microscopy analysis and $\mathrm{H}_{2} \mathrm{O}_{2}$ quantification.}

Seedlings were stained in a $1 \mathrm{mg} / \mathrm{ml} \mathrm{3,3'-diaminobenzidine} \mathrm{(DAB)} \mathrm{at} \mathrm{pH}<3$ for $24 \mathrm{~h}$ in the dark and subsequently de-stained in chloral-hydrate, as described previously (Thordal-Christensen et al. 1997). DAB staining intensities were quantified from digital photographs (Nikon Eclipse 11000) by the number of dark-brown DAB pixels relative to total pixels corresponding to plant material, using Photoshop CS3. Analysis for statistical differences were performed as described for the callose quantifications. For double staining of $\mathrm{H} 2 \mathrm{O} 2$ and callose, plant material were stained with DAB as described above, but destained in $95 \%$ ethanol instead of chloral-hydrate. Subsequently, samples were stained with aniline-blue, as described above.

\section{Supplementary material}

Figure S1: Dose-response curves of relative callose intensity (A) and number of callose depositions (B) at $24 \mathrm{~h}$ after application of Flg22 and chitosan. Callose intensity was determined as the amount of callose-corresponding pixels relative to the amount of pixels corresponding to plant material. Similarly, numbers of callose depositions were standardised to the amount of pixels corresponding to plant material. Values shown were standardised to the callose intensity in mock-treated seedlings $(0 \mu \mathrm{M}$ Flg2 2 or $0 \%$ chitosan). Different letters indicate statistically significant differences between treatments (Fisher's LSD test $\alpha=0.05$ ).

Figure S2: Quantification of basal, Flg22- and chitosan-induced callose in cotyledons of hydroponically grown Arabidopsis. Using Photoshop CS3, digital photographs of UV-illuminated cotyledons were contrast-adjusted to enable selection of callose-corresponding pixels from the background. Relative callose intensity was expressed as the total number of callose-corresponding pixels divided by the total number of pixels covering plant material (i.e. the cotyledon). Numbers of callose depositions were similarly standardised.

Figure S3: Quantification of basal and Flg22- and chitosan-induced callose in cotyledons of hydroponically grown Arabidospsis

Table S1: Reproducibility of the effects of growth conditions and abscisic acid on callose deposition in three different laboratories.

All supplemental materials can be also downloaded from:

http://apsjournals.apsnet.org/doi/suppl/10.1094/MPMI-07-10-0149

\section{References}

Asai, T., Tena, G., Plotnikova, J., Willmann, M. R., Chiu, W. L., Gomez-Gomez, L., Boller, T., Ausubel, F. M., and Sheen, J. 2002. MAP kinase signalling cascade in Arabidopsis innate immunity. Nature 415:977-83.

Asselbergh, B., De Vleesschauwer, D., and Hofte, M. 2008. Global switches and finetuning-ABA modulates plant pathogen defence. Mol Plant Microbe Interact 21:709- 
19.

Beckers, G. J., and Spoel, S. H. 2006. Fine-Tuning Plant Defence Signalling: Salicylate versus Jasmonate. Plant Biol (Stuttg) 8:1-10.

Bednarek, P., Pislewska-Bednarek, M., Svatos, A., Schneider, B., Doubsky, J., Mansurova, M., Humphry, M., Consonni, C., Panstruga, R., Sanchez-Vallet, A., Molina, A., and Schulze-Lefert, P. 2009. A glucosinolate metabolism pathway in living plant cells mediates broad-spectrum antifungal defence. Science 323:101-6.

Boller, T., and Felix, G. 2009. A renaissance of elicitors: perception of microbe-associated molecular patterns and danger signals by pattern-recognition receptors. Annu Rev Plant Biol 60:379-406.

Brown, I., Trethowan, J., Kerry, M., Mansfield, J., and Bolwell, G. P. 1998. Localization of components of the oxidative cross-linking of glycoproteins and of callose synthesis in papillae formed during the interaction between non-pathogenic strains of Xanthomonas campestris and French bean mesophyll cells. Plant Journal 15:333343.

Bueso, E., Alejandro, S., Carbonell, P., Perez-Amador, M. A., Fayos, J., Bellés, J. M., Rodriguez, P. L., and Serrano, R. 2007. The lithium tolerance of the Arabidopsis cat 2 mutant reveals a cross-talk between oxidative stress and ethylene. Plant J. 52:1052-1065.

Burmeister, W. P., Cottaz, S., Rollin, P., Vasella, A., and Henrissat, B. 2000. High resolution $\mathrm{X}$-ray crystallography shows that ascorbate is a cofactor for myrosinase and substitutes for the function of the catalytic base. J Biol Chem 275:39385-93.

Clay, N. K., Adio, A. M., Denoux, C., Jander, G., and Ausubel, F. M. 2009. Glucosinolate metabolites required for an Arabidopsis innate immune response. Science 323:95101.

Conklin, P. L., Saracco, S. A., Norris, S. R., and Last, R. L. 2000. Identification of ascorbic acid-deficient Arabidopsis thaliana mutants. Genetics 154:847-56.

de Torres-Zabala, M., Truman, W., Bennett, M. H., Lafforgue, G., Mansfield, J. W., Rodriguez Egea, P., Bogre, L., and Grant, M. 2007. Pseudomonas syringae pv. tomato hijacks the Arabidopsis abscisic acid signalling pathway to cause disease. EMBO J 26:1434-43.

Dunning, F. M., Sun, W., Jansen, K. L., Helft, L., and Bent, A. F. 2007. Identification and mutational analysis of Arabidopsis FLS2 leucine-rich repeat domain residues that contribute to flagellin perception. Plant Cell 19:3297-313.

Flors, V., Ton, J., Jakab, G., and Mauch-Mani, B. 2005. Abscisic acid and callose: Team players in defence against pathogens? J Phytopathol 153:377-383.

Fu, Z. Q., Guo, M., Jeong, B. R., Tian, F., Elthon, T. E., Cerny, R. L., Staiger, D., and Alfano, J. R. 2007. A type III effector ADP-ribosylates RNA-binding proteins and quells plant immunity. Nature 447:284-8.

Galletti, R., Denoux, C., Gambetta, S., Dewdney, J., Ausubel, F. M., De Lorenzo, G., and Ferrari, S. 2008. The AtrbohD-mediated oxidative burst elicited by oligogalacturonides in Arabidopsis is dispensable for the activation of defence responses effective against Botrytis cinerea. Plant Physiol 148:1695-706.

Gamborg, O. L., Miller, R. A., and Ojima, K. 1968. Nutrient requirements of suspension cultures of soybean root cells. Exp Cell Res 50:151-8.

Ghassemian, M., Lutes, J., Chang, H. S., Lange, I., Chen, W., Zhu, T., Wang, X., and Lange, B. M. 2008. Abscisic acid-induced modulation of metabolic and redox control pathways in Arabidopsis thaliana. Phytochemistry 69:2899-911.

Gigolashvili, T., Berger, B., Mock, H. P., Muller, C., Weisshaar, B., and Flugge, U. I. 2007. 
The transcription factor HIG1/MYB51 regulates indolic glucosinolate biosynthesis in Arabidopsis thaliana. Plant J 50:886-901.

Gomez-Gomez, L., and Boller, T. 2000. FLS2: An LRR receptor-like kinase involved in the perception of the bacterial elicitor flagellin in Arabidopsis. Molecular Cell 5:10031012.

Gomez-Gomez, L., Felix, G., and Boller, T. 1999a. A single locus determines sensitivity to bacterial flagellin in Arabidopsis thaliana. Plant Journal 18:277-284.

Gomez-Gomez, L., Felix, G., and Boller, T. 1999b. A single locus determines sensitivity to bacterial flagellin in Arabidopsis thaliana. Plant J 18:277-84.

Halkier, B. A., and Gershenzon, J. 2006. Biology and biochemistry of glucosinolates. Annu Rev Plant Biol 57:303-33.

Haweker, H., Rips, S., Koiwa, H., Salomon, S., Saijo, Y., Chinchilla, D., Robatzek, S., and von Schaewen, A. 2010. Pattern recognition receptors require N-glycosylation to mediate plant immunity. J Biol Chem 285:4629-36.

He, P., Shan, L., Lin, N.-C., Martin, G. B., Kemmerling, B., Nürnberger, T., and Sheen, J. 2006. Specific Bacterial Suppressors of MAMP signallingUpstream of MAPKKK in Arabidopsis Innate Immunity. Cell 125:563-575.

Hombach, J., and Bernkop-Schnürch, A. 2009. Chitosan solutions and particles: Evaluation of their permeation enhancing potential on MDCK cells used as blood brain barrier model. International Journal of Pharmaceutics 376:104-109.

Iriti, M., Sironi, M., Gomarasca, S., Casazza, A. P., Soave, C., and Faoro, F. 2006. Cell death-mediated antiviral effect of chitosan in tobacco. Plant Physiol Biochem 44:893-900.

Iritri, M., and Faoro, F. 2009. Chitosan as a MAMP, searching for a PRR. Plant , signalling\& Behavior 4:66-68.

Jeworutzki, E., Roelfsema, M. R., Anschutz, U., Krol, E., Elzenga, J. T., Felix, G., Boller, T., Hedrich, R., and Becker, D. 2010. Early signallingthrough the Arabidopsis pattern recognition receptors FLS2 and EFR involves $\mathrm{Ca}(2+)$-associated opening of plasma membrane anion channels. Plant J.

Kohler, A., Schwindling, S., and Conrath, U. 2002. Benzothiadiazole-induced priming for potentiated responses to pathogen infection, wounding, and infiltration of water into leaves requires the NPR1/NIM1 gene in Arabidopsis. Plant Physiol 128:1046-1056.

Kunze, G., Zipfel, C., Robatzek, S., Niehaus, K., Boller, T., and Felix, G. 2004. The N terminus of bacterial elongation factor Tu elicits innate immunity in Arabidopsis plants. Plant Cell 16:3496-3507.

Li, Y., Zhang, Q., Zhang, J., Wu, L., Qi, Y., and Zhou, J.-M. 2010. Identification of MicroRNAs Involved in Pathogen-Associated Molecular Pattern-Triggered Plant Innate Immunity. Plant Physiol. 152:2222-2231.

Lipka, V., Dittgen, J., Bednarek, P., Bhat, R., Wiermer, M., Stein, M., Landtag, J., Brandt, W., Rosahl, S., Scheel, D., Llorente, F., Molina, A., Parker, J., Somerville, S., and Schulze-Lefert, P. 2005. Pre- and postinvasion defences both contribute to nonhost resistance in Arabidopsis. Science 310:1180-3.

Lu, X., Tintor, N., Mentzel, T., Kombrink, E., Boller, T., Robatzek, S., Schulze-Lefert, P., and Saijo, Y. 2009. Uncoupling of sustained MAMP receptor signallingfrom early outputs in an Arabidopsis endoplasmic reticulum glucosidase II allele. Proc Natl Acad Sci U S A 106:22522-7.

Mauch-Mani, B., and Mauch, F. 2005. The role of abscisic acid in plant-pathogen interactions. Curr. Opin. Plant Biol. 8:409-414.

Millet, Y. A., Danna, C. H., Clay, N. K., Songnuan, W., Simon, M. D., Werck-Reichhart, D., 
and Ausubel, F. M. 2010. Innate immune responses activated in Arabidopsis roots by microbe-associated molecular patterns. Plant Cell 22:973-90.

Navarro, L., Zipfel, C., Rowland, O., Keller, I., Robatzek, S., Boller, T., and Jones, J. D. 2004. The transcriptional innate immune response to flg22. Interplay and overlap with Avr gene-dependent defence responses and bacterial pathogenesis. Plant Physiol 135:1113-28.

Nicaise, V., Roux, M., and Zipfel, C. 2009. Recent advances in PAMP-triggered immunity against bacteria: pattern recognition receptors watch over and raise the alarm. Plant Physiol 150:1638-47.

Nishimura, M. T., Stein, M., Hou, B. H., Vogel, J. P., Edwards, H., and Somerville, S. C. 2003. Loss of a callose synthase results in salicylic acid-dependent disease resistance. Science 301:969-72.

Paul, M. J., and Driscoll, S. P. 1997. Sugar repression of photosynthesis: the role of carbohydrates in signalling nitrogen deficiency through source:sink imbalance. Plant, Cell and Environment 20:110-116.

Pogany, M., von Rad, U., Grun, S., Dongo, A., Pintye, A., Simoneau, P., Bahnweg, G., Kiss, L., Barna, B., and Durner, J. 2009. Dual Roles of Reactive Oxygen Species and NADPH Oxidase RBOHD in an Arabidopsis-Alternaria Pathosystem. Plant Physiol. 151:1459-1475.

Ridley, B. L., O'Neill, M. A., and Mohnen, D. 2001. Pectins: structure, biosynthesis, and oligogalacturonide-related signaling. Phytochemistry 57:929-67.

Robatzek, S., Chinchilla, D., and Boller, T. 2006. Ligand-induced endocytosis of the pattern recognition receptor FLS2 in Arabidopsis. Genes Dev 20:537-42.

Robert-Seilaniantz, A., Navarro, L., Bari, R., and Jones, J. D. 2007. Pathological hormone imbalances. Curr Opin Plant Biol 10:372-9.

Saijo, Y. 2010. ER quality control of immune receptors and regulators in plants. Cell Microbiol.

Saijo, Y., Tintor, N., Lu, X., Rauf, P., Pajerowska-Mukhtar, K., Haweker, H., Dong, X., Robatzek, S., and Schulze-Lefert, P. 2009. Receptor quality control in the endoplasmic reticulum for plant innate immunity. EMBO J 28:3439-49.

Sheen, J. 1990. Metabolic repression of transcription in higher plants. Plant Cell 2:1027-38.

Suarez-Rodriguez, M. C., Adams-Phillips, L., Liu, Y., Wang, H., Su, S.-H., Jester, P. J., Zhang, S., Bent, A. F., and Krysan, P. J. 2007. MEKK1 Is Required for flg22Induced MPK4 Activation in Arabidopsis Plants. Plant Physiol. 143:661-669.

Thordal-Christensen, H., Zhang, Z., Wei, Y., and Collinge, D. B. 1997. Subcellular localization of $\mathrm{H} 2 \mathrm{O} 2$ in plants. $\mathrm{H} 2 \mathrm{O} 2$ accumulation in papillae and hypersensitive response during the barley-powdery mildew interaction. Plant J. 11:1187-1194.

Ton, J., Flors, V., and Mauch-Mani, B. 2009. The multifaceted role of ABA in disease resistance. Trends Plant Sci 14:310-7.

Ton, J., Jakab, G., Toquin, V., Flors, V., Iavicoli, A., Maeder, M. N., Metraux, J. P., and Mauch-Mani, B. 2005. Dissecting the beta-aminobutyric acid-induced priming phenomenon in Arabidopsis. Plant Cell 17:987-99.

Ton, J., and Mauch-Mani, B. 2004. Beta-amino-butyric acid-induced resistance against necrotrophic pathogens is based on ABA-dependent priming for callose. Plant $\mathrm{J}$ 38:119-30.

Wang, L., Tsuda, K., Sato, M., Cohen, J. D., Katagiri, F., and Glazebrook, J. 2009. Arabidopsis CaM binding protein CBP60g contributes to MAMP-induced SA accumulation and is involved in disease resistance against Pseudomonas syringae. PLoS Pathog 5:e1000301. 
Xing, Y., Jia, W., and Zhang, J. 2008. AtMKK1 mediates ABA-induced CAT1 expression and $\mathrm{H} 2 \mathrm{O} 2$ production via AtMPK6-coupled signallingin Arabidopsis. Plant J. 54:440-451.

Yakushiji, S., Ishiga, Y., Inagaki, Y., Toyoda, K., Shiraishi, T., and Ichinose, Y. 2009. Bacterial DNA activates immunity in Arabidopsis thaliana. J Gen Plant Pathol 75:227-234.

You, M. K., Shin, H. Y., Kim, Y. J., Ok, S. H., Cho, S. K., Jeung, J. U., Yoo, S. D., Kim, J. K., and Shin, J. S. 2010. Novel bifunctional nucleases, OmBBD and AtBBD1, are involved in abscisic acid-mediated callose deposition in Arabidopsis. Plant Physiol 152:1015-29.

Zhang, J., Shao, F., Li, Y., Cui, H., Chen, L., Li, H., Zou, Y., Long, C., Lan, L., Chai, J., Chen, S., Tang, X., and Zhou, J. M. 2007. A Pseudomonas syringae effector inactivates MAPKs to suppress PAMP-induced immunity in plants. Cell Host Microbe 1:175-85.

Zimmerli, L., Jakab, G., Métraux, J.-P., and Mauch-Mani, B. 2000. Potentiation of pathogen-specific defence mechanisms in Arabidopsis by b-aminobutyric acid. Proc. Natl. Acad. Sci. USA 97:12920-12925. 


\section{Supplementary material}

(a)

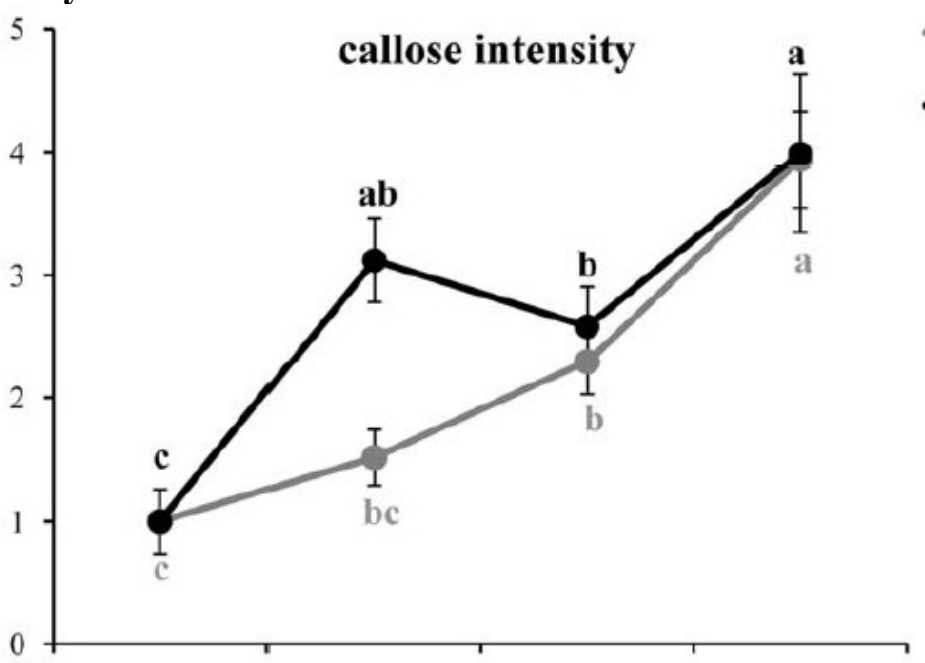

(b)

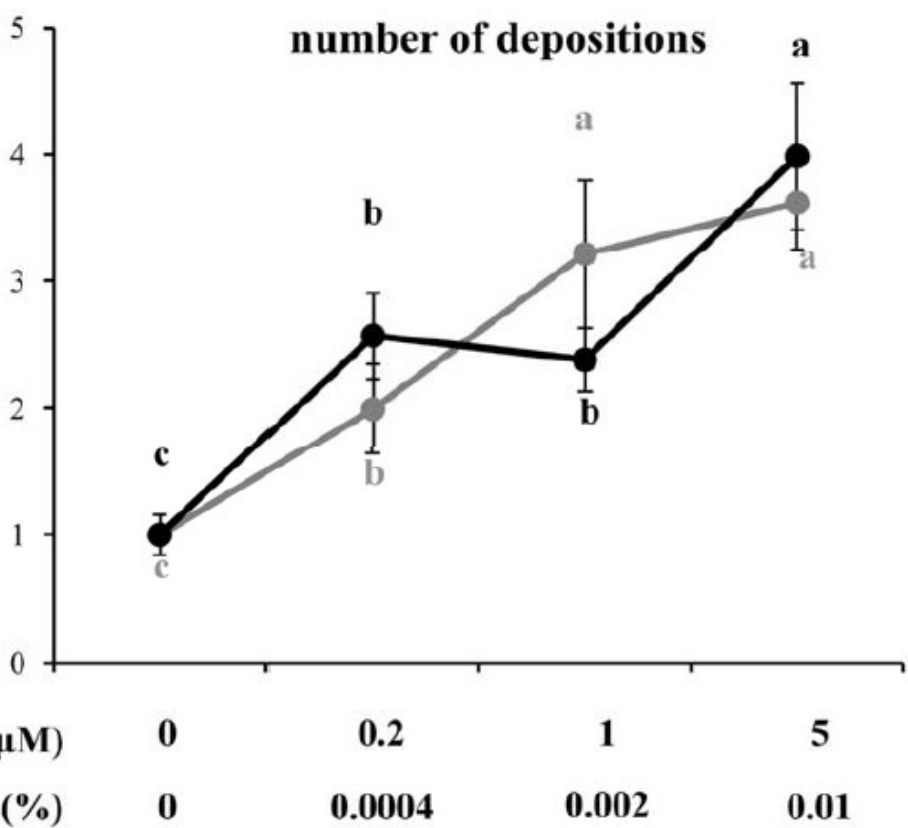

Supplementary Fig. S1. Dose-response curves of relative callose intensity(a) and number of callose depositions (b) at 24 h after application of Flg22 and chitosan. Callose intensity was determined as the number of callose-corresponding pixels relative to the number of pixels corresponding to plant material (i.e., surface area). Numbers of callose depositions were similarly standardized to the surface area. Values shown are relative to the callose intensity in mock-treated seedlings $(0$ $\mu \mathrm{M}$ Flg22 or $0 \%$ chitosan). Different letters indicate statistically significant differences between treatments (Fisher's LSD test $\alpha=0.05$ ). 

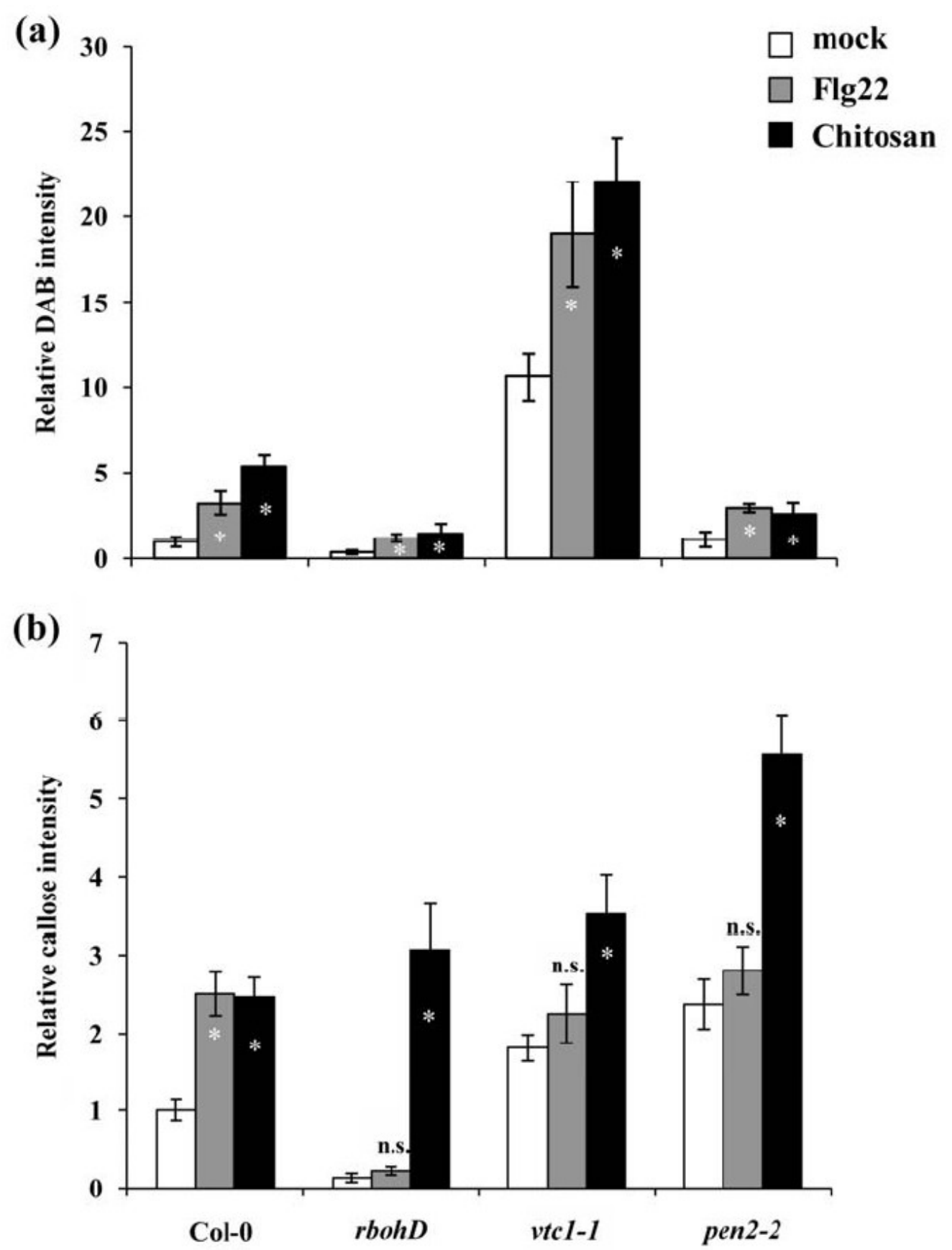

Supplementary Fig. S2. Effect of mutations in RBOHD, VTC, or PEN2 on $\mathrm{H}_{2} \mathrm{O}_{2}$ production (a) and callose deposition (b) in mock-treated seedlings and seedlings treated with $1 \mu \mathrm{M} \mathrm{Flg} 22$ or $0.002 \%$ chitosan. For further experimental details, see legend of Figure 8. 

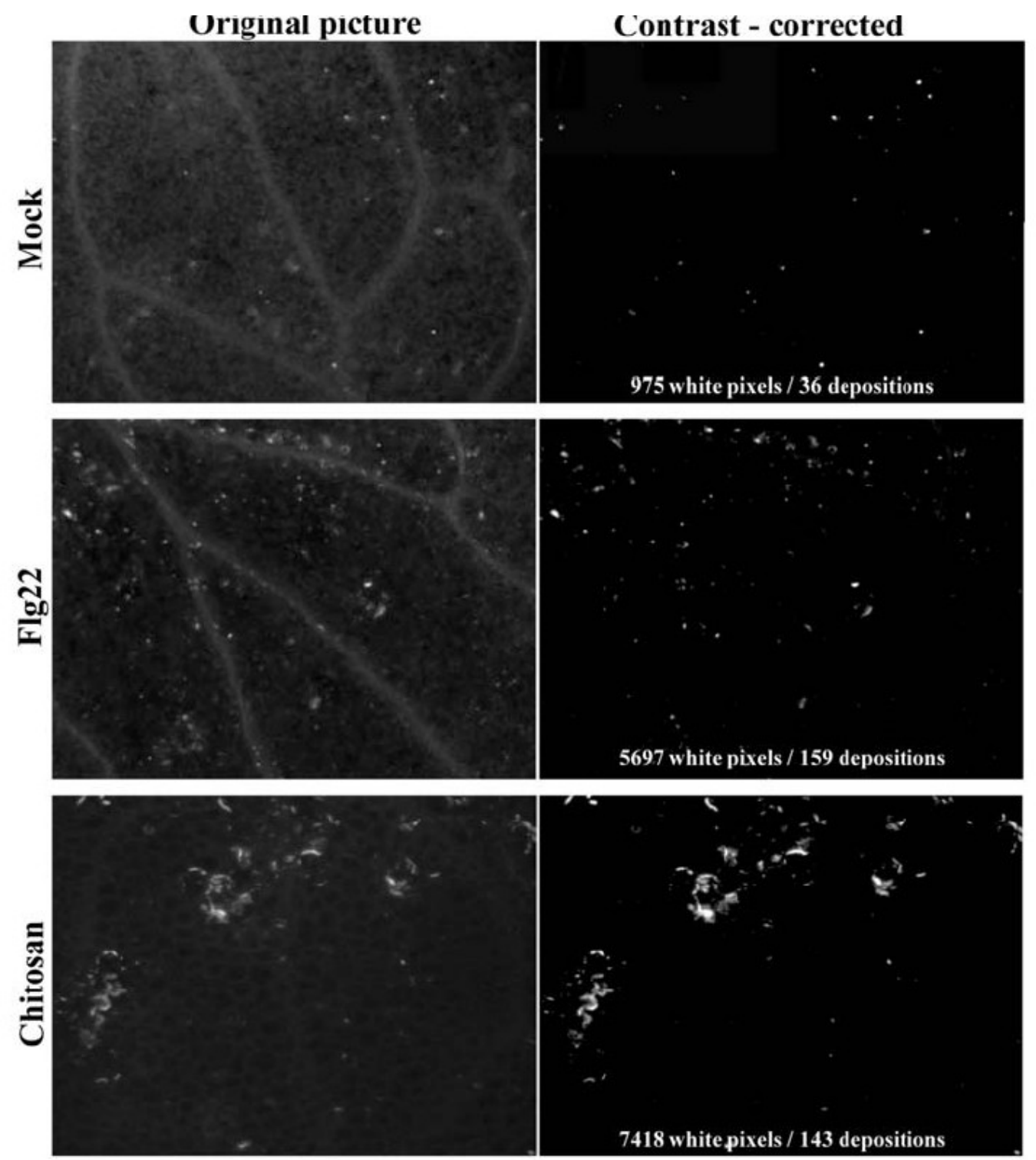

Supplementary Fig. S3. Quantification of basal, Flg22- and chitosan-induced callose in cotyledons of hydroponically grown Arabidopsis. Using Photoshop CS3, digital photographs of UV-illuminated cotyledons were contrast-adjusted to enable selection of callose-corresponding pixels from the background. Relative callose intensity was expressed as the total number of callose-corresponding pixels divided by the total number of pixels covering plant material (i.e., the cotyledon). Numbers of callose depositions were similarly standardized. 


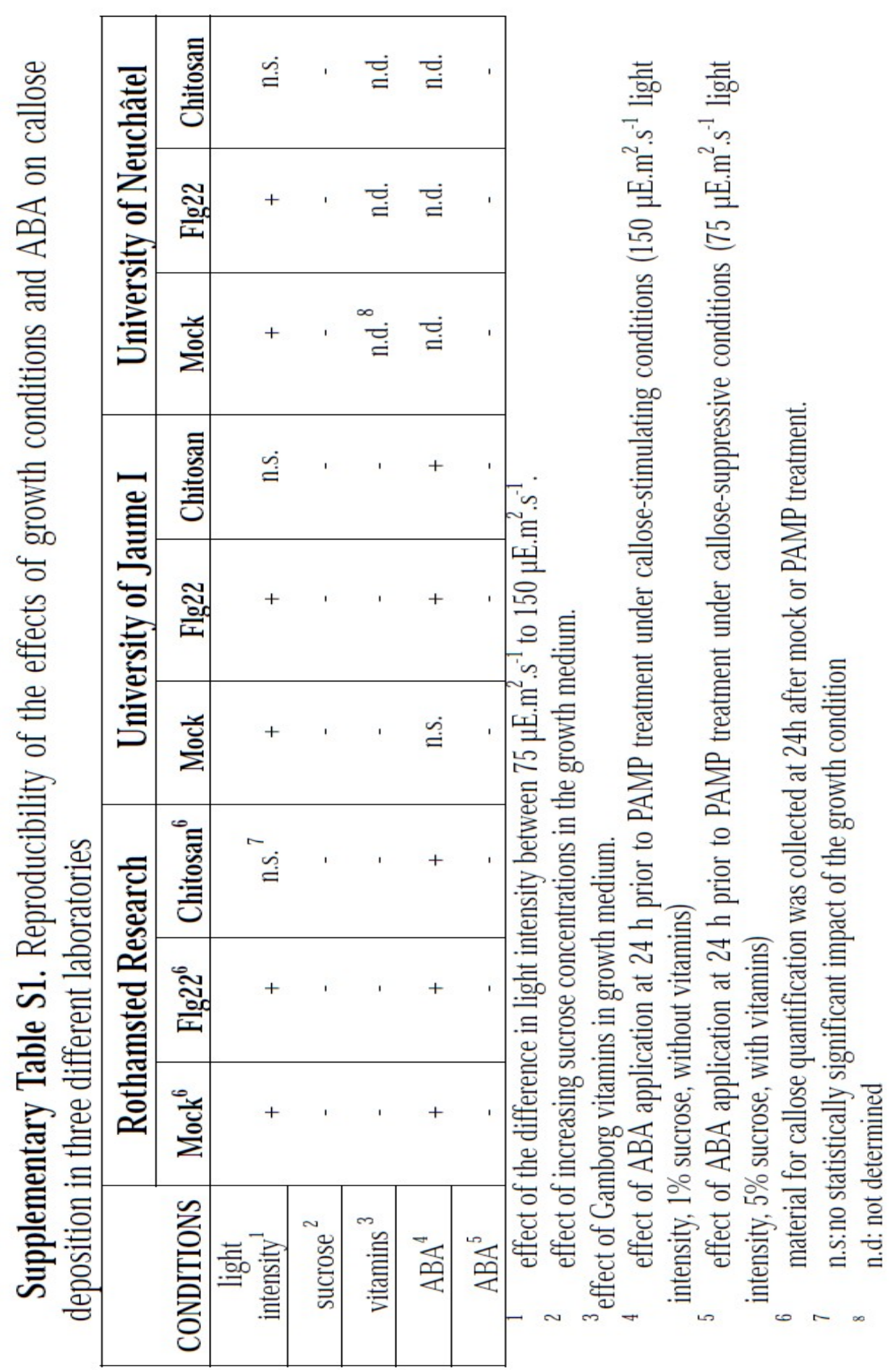



CHAPTER 3

Fine tuning of ROS homeostasis regulates primed immune responses in Arabidopsis 


\section{Abstract}

In response to selected environmental stimuli, plants can prime their immune system, which allows them to express a faster and stronger defence reaction to subsequent attack by pathogens. Priming of Arabidopsis by the chemical agent betaaminobutyric acid (BABA) results in accelerated $\mathrm{H}_{2} \mathrm{O}_{2}$ accumulation, followed by augmented callose deposition after subsequent challenge treatment with the pathogen-associated molecular pattern (PAMP) chitosan or the necrotrophic fungus Plecthosphaerella cucumerina (P.cucumerina). These primed immune responses were not observed upon challenge treatment with the bacterial PAMP Flg22. Analysis of mutants impaired in reactive oxygen species (ROS) production ( $r b o h D)$ or ROS scavenging ( $\mathrm{pad} 2, \mathrm{vtc} 1$ and cat 2 ) revealed that ROS homeostasis modulates primed immune expression upon challenge with chitosan or $P$. cucumerina. Moreover, $r b o h D$ and $p a d 2$ were also impaired in BABA-induced resistance against $P$. cucumerina. Furthermore, we discovered an additional role for GSH1 in basal resistance to $P$. cucumerina, supported by the hypersensitivity of the pad 2 mutant to the necrotroph, whereas rbohD displayed wild-type levels of basal resistance. The primed state of the plant seems to require a more oxidized cellular status in order to establish a functional protection that can help to overcome the infection. Gene expression analysis revealed a direct induction of $\mathrm{RBOHD}, \mathrm{GSH} 1$ and $V T C 1$ after BABA treatment. However, upon challenge with chitosan or P. cucumerina, APXI and $G S H 1$ transcripts were dramatically repressed by BABA in comparison to challenged control plants, probably to provide an adequate oxidized environment in the cell. Together, our data indicate that ROS homeostasis regulates primed responses of Arabidopsis to fungal pathogens. 


\section{Introduction}

Throughout their life cycle, plants are constantly threatened by potentially harmful microbes. To cope with these threats, plants have evolved a sophisticated immune system that allow them to respond to invaders with inducible defence mechanisms. The speed and intensity by which these inducible defences are activated largely determines the level of resistance expressed against plant attackers. Pattern-recognition receptors (PRR) allow plants to recognize pathogenic microbes at an early stage of infection, which detect pathogen/microbe/damage-associated molecular patterns (PAMPs, MAMPs, DAMPs) and activate innate immune responses, commonly referred to as PAMP-triggered immunity (PTI) (Boller and Felix, 2009; Zipfel, 2009). Among many other responses, PTI includes ROS production, activation of MAPK cascades, callose deposition, synthesis of secondary metabolites and transcriptional reprogramming through WRKY transcription factors. A coevolutionary arms race between plant pathogens and their hosts provided plants with an extension of their innate immune system, called effector-triggered immunity (ETI) (Jones and Dangl, 2006; Bent and Mackey, 2007). ETI allows plants to detect and respond to the attempt of the pathogens to suppress the host immune responses. Both PTI and ETI share partially similar signalling pathways, such as ROS production and changes in gene expression. However, the overarching factors determining efficiency of plant innate immune responses are speed and intensity relative to the colonization rate of a potential pathogen (Tsauda and Katagiri, 2010).

Besides innate immune responses, plants can also acquire a 'sensitized defence state' in response to specific environmental stimuli. This so-called "priming of defence" is an important mechanism underpinning induced resistance (IR) phenomena in plants (Pastor et al., 2012). The primed defence state permits a faster and stronger induction of innate immune responses to attackers (Conrath et al., 2006; Conrath, 2011; Pastor et al., 2012). Hence, defence priming is an adaptive response that synergizes the plant's innate immune system. Priming can stimulate different layers of the defence signalling network in the plant, ranging from locally attacked tissues to systemic parts of the plant. Previous research has revealed that priming can be based on enhanced accumulation of defence signalling proteins, such as MAP protein kinases or WRKY transcription factors (Beckers et al., 2009; Van der Ent et al., 2009). Recent publications have shown that some IR responses of Arabidopsis and tomato (Solanum lycopersicum) can be transmitted to progeny, suggesting a partially epigenetic basis of defence priming (Luna et al., 2012; Rasmann et al., 2012; Slaughter et al., 2012). Although there are many open questions remaining about the molecular mechanisms controlling defence priming, it is well documented that the phenomenon is associated with sensitization of the response pathways to the central defence hormones salicylic acid (SA), jasmonic acid (JA) and abscisic acid (ABA) (Jakab et al., 2005; Ton et al., 2005; Pozo et al., 2008; Van der Ent et al., 2009).

Various chemicals can mimic biological IR responses to pathogens or nonpathogenic rhizobacteria (Kessmann et al., 1994; Friedrich et al 2003; Vicedo et al., 2009). Amongst these, BABA has emerged as a very effective mimic of SA-dependent and SAindependent IR responses (Zimmerli et al., 2000; Ton et al., 2005; Van der Ent et al., 2009). The non-protein amino acid protects plants against necrotrophic (Plectosphaerella cucumerina, Botrytis cinerea, Alternaria brassicicola), biotrophic pathogens (Hyaloperonospora arabidopsidis, Pseudomonas syringae) and abiotic stress (Zimmerli et al, 2000; Jakab et al 2001; Ton and Mauch-Mani 2004; Jakab et al 2005; Ton et al 2005; 
Flors et al., 2008), and is associated with relatively small fitness costs (van Hulten et al, 2006). Its mode of action relies on two different mechanisms. Apart from a priming of SAinducible defence genes (Zimmerli et al., 2000, Ton et al., 2005), BABA also primes SAindependent deposition of callose-rich papillae. Interestingly, the latter priming response was found to be under control by the plant hormone ABA (Ton and Mauch-Mani, 2004, Flors et al., 2008). BABA-induced resistance (BABA-IR) in the genetic model plant Arabidopsis has become a popular model system to study the molecular mechanisms controlling defence priming in plants (Pastor et al., 2012).

Production of ROS is known to be one of the earliest events after microbe recognition (Wojtaszek 1997). ROS are by-products of the reduction of molecular oxygen. The equilibrium between ROS scavenging and ROS synthesis safeguards primary metabolism during stress tolerance responses (Pei et al., 2000; Apel and Hirt, 2004; Gechev and Hille, 2005; Laloi et al., 2007; Miller et al., 2007). Plants have enzymatic and nonenzymatic strategies to maintain this equilibrium. Scavenging systems, such as catalases (CAT), peroxidases (e.g. ascorbate peroxidase, glutathione peroxidase), superoxide dismutase (SOD) and the non-enzymatic ascorbate/glutathione (ASA/GSH) cycle are ubiquitous in all cell compartments, thereby highlighting ROS homeostasis as an essential process for cellular physiology. This multifaceted role of ROS makes it difficult to pin point a specific function of ROS in plant defence. Furthermore, apart from direct toxic effects of $\mathrm{H}_{2} \mathrm{O}_{2}$, ROS also act as important extracellular and intracellular signalling molecules (Laloi et al., 2004; Foyer and Noctor, 2005; D'Autreaux and Toledano, 2007; Meng et al., 2010; Mittler et al., 2011). Amongst them, $\mathrm{H}_{2} \mathrm{O}_{2}, \mathrm{NO}$, and $\mathrm{O}_{2}{ }^{-}$show specific reactivity with proteins, making them suitable for various signalling purposes (D'Autreaux and Toledano 2007; Tada et al., 2008; Spoel et al., 2010). To accurately develop this stress-related signalling function, ROS production must be tightly regulated to ensure specific responses along different cellular targets (Neill et al., 2002; Foyer and Noctor, 2005; D'Autreaux and Toledano, 2007; Desikan et al., 2008; Miller et al., 2009). $\mathrm{H}_{2} \mathrm{O}_{2}$ can diffuse across membranes and is relatively stable. It is, therefore, the main ROS for extracellular cell-tocell communication. ROS signalling can have a profound impact on nuclear gene expression, encoding resistance proteins and pathogen-inducible transcription factors (Gadjev et al., 2006).

The signal transduction from ROS production to gene expression remains relatively poorly understood, but likely involves redox-dependent modifications of signalling proteins at Cys residues (Jonak et al 2002; Hancock et al 2006; Spoel and Loake, 2011). Other putative mechanisms involve direct sensing of ROS through redox-sensitive elements in transcription factor proteins (Neill et al 2002; Mou et al 2003), or metabolites implicated in redox homeostasis, such as GSH (Ghanta et al., 2011; Ghanta and Chattopadhyay, 2011) and L-ascorbic acid (ASA; Arrigoni and De Tullio, 2002; Pastori et al 2003).

Further evidence for ROS participation in defence comes from the crosslinking of phenolics during papillae formation (Lamb and Dixon, 1997). Callose is also part of cell wall appositions and accumulates during defence responses in a coordinated fashion with $\mathrm{H}_{2} \mathrm{O}_{2}$ (Luna et al., 2011). Both ROS and callose are PAMP-inducible. The bacterial PAMP Flg22, a 22-amino sequence of the conserved N-terminal part of flagellin (Felix et al 1999; Gómez-Gómez and Boller, 2000) and the fungal PAMP chitosan, a randomly distributed $\beta$ $(1,4)$-linked polymer of D-glucosamide and acetylglucosamine (Iriti and Faoro, 2009), are widely used to study the PTI responses in plants. Previously, we observed that the timing of 
ROS and callose deposition in response to both PAMPs differs substantially. For instance, $\mathrm{H}_{2} \mathrm{O}_{2}$ and callose deposition co-localised upon chitosan treatment, but not in response to Flg22 treatment (Luna et al., 2011). Since priming of defence against necrotrophic pathogens is mediated by an early accumulation of callose (Ton and Mauch-Mani 2004, Flors et al 2008, García-Andrade et al 2012), and $\mathrm{H}_{2} \mathrm{O}_{2}$ and callose production are spatially and temporally coordinated responses upon treatment with the fungal PAMP chitosan (Luna et al., 2011), we hypothesized that ROS homeostasis plays an important role in the participation of defence priming against fungal pathogens.

To assess the role of ROS signalling in defence priming, we studied the immune response of BABA-primed plants to challenge treatment with Flg22, chitosan, and the necrotrophic pathogen $P$. cucumerina. Here we show that BABA primes immune responses to the fungal PAMP chitosan, but not in response to challenge with the bacterial PAMP Flg22. We subsequently provide evidence that the primed immune response to chitosan and P. cucumerina requires redox regulation mediated by $R B O H D$ and GSHI.

\section{Results}

\section{Enhanced production of $\mathrm{H}_{2} \mathrm{O}_{2}$ and callose marks the BABA-primed immune response to chitosan but not to Flg22.}

ROS and callose are induced in response to MAMPs/PAPMs (Galletti et al., 2008; Luna et al., 2011). To investigate whether BABA could enhance the plant's reaction to PAMPs, we used a previously optimized hydroponic cultivation system in Murashige and Skoog medium containing 1\% sucrose (Luna et al., 2011). Several BABA concentrations were applied to 7-day old seedlings to obtain the optimal concentration to induce priming in hydroponically grown Arabidopsis (Fig. S1). $\mathrm{H}_{2} \mathrm{O}_{2}$ and callose deposition were examined at 1 day after PAMP application to 8-day old seedlings, using digital quantification of DAB and aniline-blue stained cotyledons, respectively (Luna et al., 2011). This analysis revealed that BABA at $1 \mathrm{ppm}$ is the minimal concentration to cause augmented induction of ROS and callose by chitosan (Fig S1), which was selected for all subsequent experiments. On the other hand, none of the BABA applications augmented $\mathrm{H}_{2} \mathrm{O}_{2}$ and callose production upon Flg22 treatment (Figures 1 and S1). Hence, BABA-induced priming specifically acts upon the pathways controlling chitosan-induced $\mathrm{H}_{2} \mathrm{O}_{2}$ and callose, whereas regulation of Flg22induced $\mathrm{H}_{2} \mathrm{O}_{2}$ and callose is unaffected by BABA.

\section{Primed production of chitosan-induced $\mathrm{H}_{2} \mathrm{O}_{2}$ and callose requires intact ROS homeostasis}

To assess the relevance of ROS metabolism in priming of chitosan-induced $\mathrm{H}_{2} \mathrm{O}_{2}$ and callose, we analyzed mutants impaired in ROS production or scavenging. Mutant rbohD is blocked in superoxide-generating NADPH oxidase gene RBOHD (Pógany et al., 2009), which reduces its capacity to generate PAMP-induced $\mathrm{H}_{2} \mathrm{O}_{2}$ (Torres et al., 2002; Luna et al., 2011). On the other hand, cat2, and $v t c 1$ are impaired in peroxisomal catalase (Bueso et al, 2007) and production of L-ascorbic acid (ASA; Conklin et al 2000), respectively, causing exaggerated $\mathrm{H}_{2} \mathrm{O}_{2}$ production due to their reduced ROS scavenging capacity (Luna et al., 2011). The pad 2 mutant is impaired in $\gamma$-glutamilcysteine synthetase (GSH1; Parisy et 
al., 2007), the first dedicated step of GSH biosynthesis, causing disruption of the HalliwellAsada cycle controlling ROS homeostasis (Foyer and Noctor, 2005 a,b).
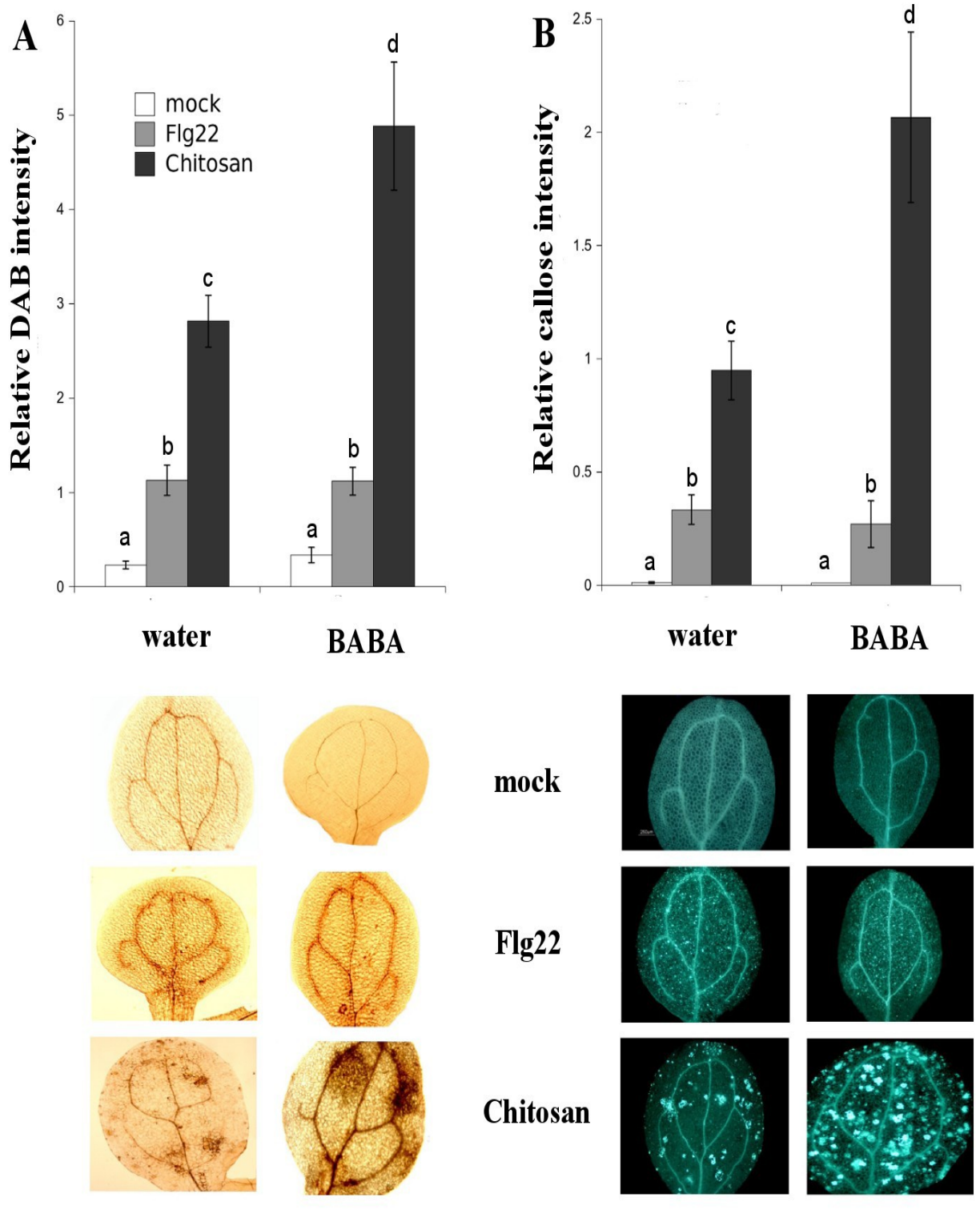

Figure 1: Priming effect upon Flg22 and chitosan treatment. A, $\mathrm{H}_{2} \mathrm{O}_{2}$ production and B, callose accumulation upon treatment of $1 \mu \mathrm{M}$ Flg22 or $0.01 \%$ chitosan. Cotyledons were treated with $1 \mathrm{ppm}$ of BABA as a priming agent, 24h prior to pathogen-associated molecular pattern treatment. Data shown are average values $( \pm$ standard error of the mean; $n>15)$ of relative staining intensities. Different letters indicate statistically significant differences between treatments (Fisher's least significant differences test; $\alpha=0.05$ ). 
Application of chitosan to the rbohD mutant triggered $\mathrm{H}_{2} \mathrm{O}_{2}$ and callose deposition, although these responses were somewhat reduced in comparison to the wild-type (Fig. 2). Furthermore, pre-treatment with BABA failed to augment chitosan-induced $\mathrm{H}_{2} \mathrm{O}_{2}$ and callose in this mutant. Hence, RBOHD is essential for primed expression of chitosan-induced $\mathrm{H}_{2} \mathrm{O}_{2}$ and callose. Mutants cat2 and vtcl showed strongly augmented levels of $\mathrm{H}_{2} \mathrm{O}_{2}$ and callose under all conditions tested (Fig. 2). In both mutants, BABA failed to augment chitosaninduced $\mathrm{H}_{2} \mathrm{O}_{2}$ and callose further, probably because these responses have reached saturation in these mutants. Finally, control-treated pad2 plants showed levels of chitosan-induced $\mathrm{H}_{2} \mathrm{O}_{2}$ and callose that were comparable to that in wild-type plants. However, pre-treatment of pad 2 with BABA failed to increase chitosan-induced $\mathrm{H}_{2} \mathrm{O}_{2}$ and callose, indicating that all tested genes are necessary for primed expression of both events.

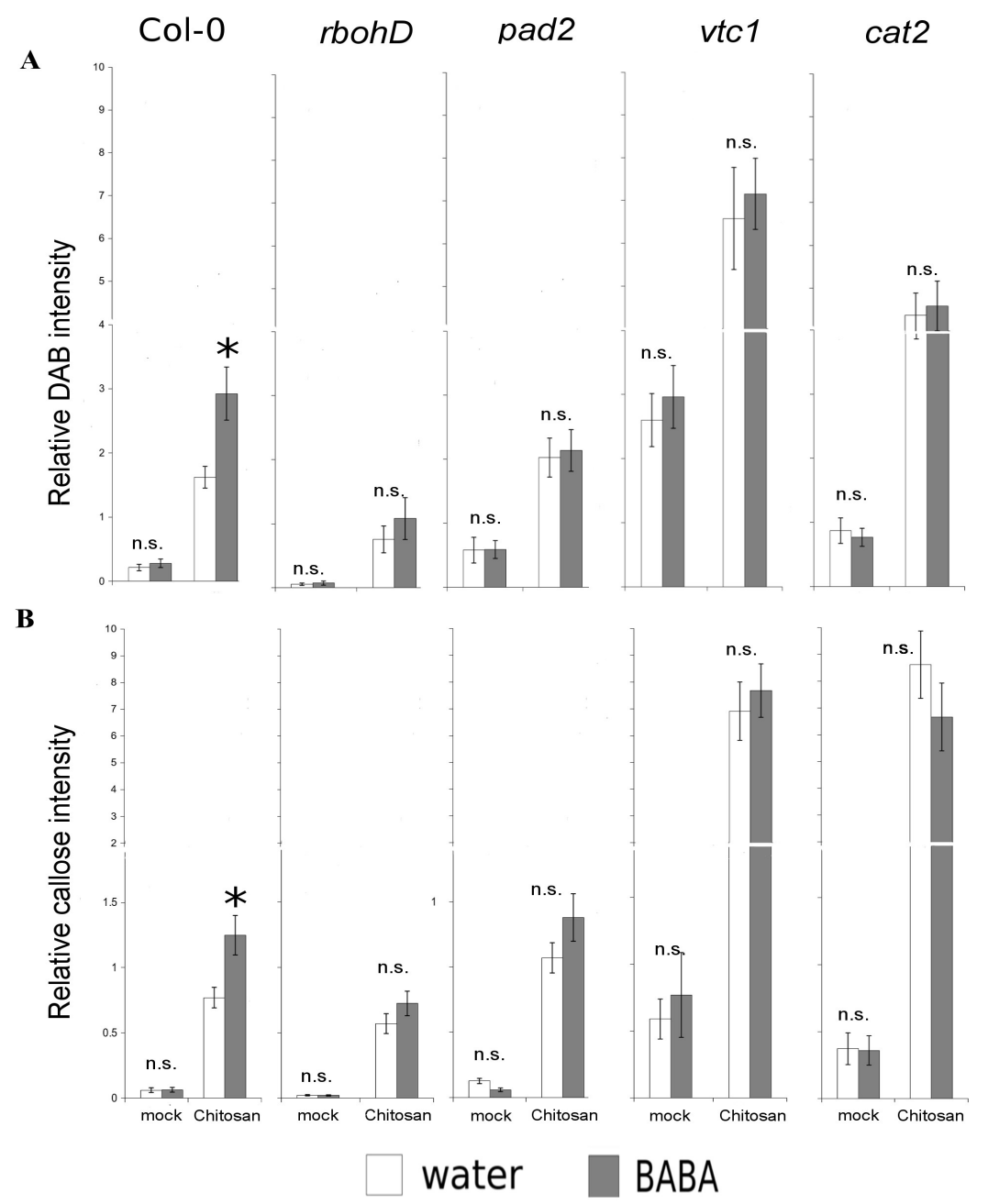

Figure 2: Priming phenotype in ROS homeostasis-blocked plants. $\mathbf{A}, \mathrm{H}_{2} \mathrm{O}_{2}$ production and $\mathbf{B}$, callose accumulation upon treatment of $0.01 \%$ chitosan. Cotyledons were treated with $1 \mathrm{ppm}$ of BABA as a priming agent, 24h prior to pathogenassociated molecular pattern treatment. Data shown are average values ( \pm standard error of the mean; $n>15)$ of relative staining intensities. Asterisks indicate statistically significant changes in response to BABA treatment (Student's t-test; $\alpha=$ $0.05)$. n.s. $=$ no statistically significant difference between water- and BABA- treated seedlings. 
Mutants edr1 and lin1 show constitutive priming of Flg22- and chitosaninduced $\mathrm{H}_{2} \mathrm{O}_{2}$ and callose.

To determine whether ROS production and its coordinated accumulation in relation to callose is a general mechanism of priming, or an exclusive response to BABA, we performed experiments with two mutants expressing constitutive defence priming: edrl and lin1 (van Hulten et al., 2006; Camañes et al 2012). In the absence of either Flg22 or chitosan, edrl and linl did not accumulate enhanced callose or hydrogen peroxide (Fig. 3). However, PAMP challenge in MS medium caused augmented levels of Flg22- and chitosaninduced $\mathrm{H}_{2} \mathrm{O}_{2}$ and callose in comparison to wild-type plants. Although these observations suggest that augmented deposition of PAMP-induced $\mathrm{H}_{2} \mathrm{O}_{2}$ of and callose are common hallmarks of defence priming, the priming response induced by BABA did not act on Flg22triggered responses (Figure 1), while $e d r l$ and $\operatorname{lin} 1$ displayed primed responsiveness to both PAMPs. Therefore, it can be concluded that edrl-and linl-induced defence priming, although share some common responses, is based on partially different mechanisms than BABA-induced defence priming.
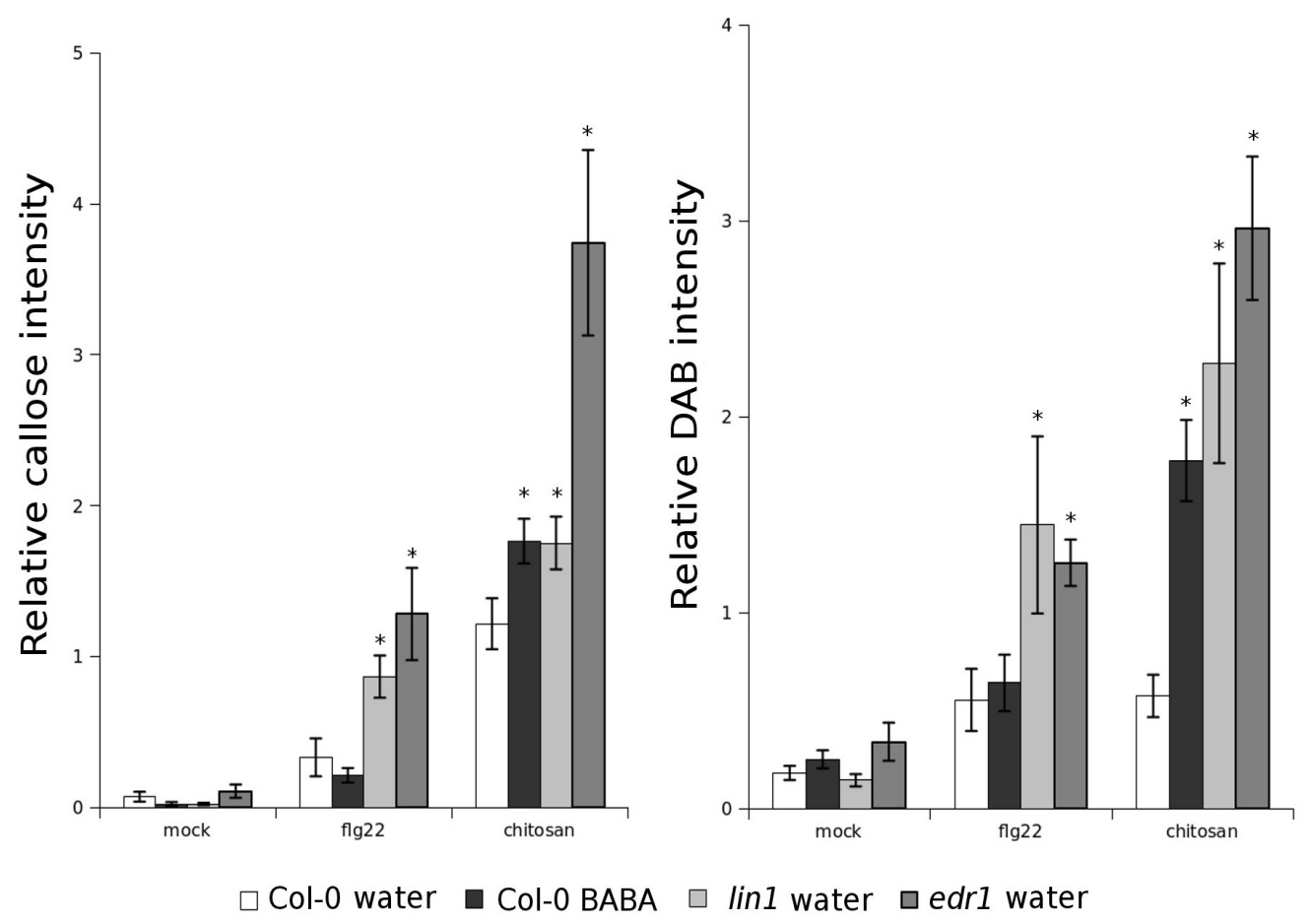

Figure 3: $\mathrm{H}_{2} \mathrm{O}_{2}$ production and callose accumulation were quantified by determining the intensities of stained cotyledons treated with Flg22 or chitosan. Only wild type seedlings were both, water and BABA treated, meanwhile priming mutants were only water treated. Asterisks indicate statistically significant differences compared with Col-0 water treated plants. For further details see above figures.

BABA alters gene expression contributing to increase the $\mathrm{H}_{2} \mathrm{O}_{2}$ upon chitosan challenge

Since previous observations showed that intact ROS homeostasis is required for full expression of priming induced by BABA, we have investigated whether BABA promotes a 
specific gene transcriptional profiling upon chitosan treatment (Fig. 2). Thus, the gene expression of $R B O H D, G S H 1, V T C 1$ and CAT2 during PTI triggered by chitosan were determined either in mock or BABA treated plants. In addition, a cytosolic ascorbate peroxidase, $A P X 1$, was also tested by its implication in $\mathrm{H}_{2} \mathrm{O}_{2}$ detoxification (Pnueli et al., 2003; Koussevitzky et al., 2008), the maintenance in ROS-related gene network and its relevance in limiting the propagation of oxidative processes (De Gara et al, 2003; Davletova et al 2005). Chitosan challenge induces $R B O H D, A P X 1$ and GSH1 while it represses CAT2 expression (Fig. 4). This gene profiling lead us to hypothesize that PTI promotes higher $\mathrm{H}_{2} \mathrm{O}_{2}$ levels in the cytoplasm. Interestingly, $A P X 1$ depends on ASA availability (Ishikawa and Shigeoka, 2008), thus its enhancement needs VTC1 to coordinately promote the synthesis of higher ASA levels. This situation, in turn, needs more GSH to recycle the amount of oxidized ASA by the ASA/GSH cycle (Foyer and Noctor, 2011). This situation seems to be modified by BABA treatments. Primed plants showed higher RBOHD levels, but on the contrary, APXI is dramatically repressed (Fig. 4). This two major changes after BABA treatment in chitosan challenged plants may explain why priming rends such high levels of $\mathrm{H}_{2} \mathrm{O}_{2}$ that could positively regulate faster and stronger callose accumulation. BABA-pretreated plants also show an increased gene expression of GSHI and $\mathrm{VTCl}$ only in unchallenged plants. This situation leads to higher levels of GSH (Fig 5B) and probably ASA in the plant that, if needed, could keep $\mathrm{H}_{2} \mathrm{O}_{2}$ at low levels. Contrastingly, once chitosan is present $\mathrm{BABA}$ again represses $\mathrm{GSH} 1$ which is clearly contributing to an oxidated status of the cell. This is further confirmed by the lower levels of GSH/GSSG determined in BABAchallenged plants (Fig. 5B). It is worthy to mention that it has not been observed a toxic effect of BABA due to massive $\mathrm{H}_{2} \mathrm{O}_{2}$ accumulation either in mock or in challenged plants. It is clear that the control of redox homeostasis during PTI differs between mock and primed plants suggesting a high level of oxidative species such as $\mathrm{H}_{2} \mathrm{O}_{2}$ and, at the same time, scavenging mechanisms in BABA-treated Arabidopsis. The reason why primed plants can keep both oxidants and scavengers together during priming remains unknown, but compartmentalization in different cell organelles is a very likely explanation (Conklin and Barth, 2004; Queval et al 2011).

\section{Primed immune expression against the necrotroph $P$. cucumerina is associated with augmented deposition of $\mathrm{H}_{2} \mathrm{O}_{2}$ and callose.}

BABA-IR against necrotrophic pathogens is based on a faster and stronger accumulation of callose-rich papillae depositions (Ton and Mauch-Mani, 2004; Flors et al., 2008). To verify whether the coordinated accumulation of $\mathrm{H}_{2} \mathrm{O}_{2}$ and callose in hydroponically cultivated Arabidopsis seedlings can be extrapolated to the interaction between soil-grown Arabidopsis and a necrotrophic pathogen, we tested $\mathrm{H}_{2} \mathrm{O}_{2}$ and callose accumulation in primed and un-primed Arabidopsis after inoculation with the nectrotrophic fungus $P$. cucumerina. Five-week-old plants were pretreated with water or $150 \mu \mathrm{M}$ of BABA, and subsequently challenged with P. cucumerina. As it is shown in figure 5, BABAtreated plants showed strongly augmented accumulation of callose and $\mathrm{H}_{2} \mathrm{O}_{2}$ following $P$. cucumeria infection, which correlated with reduced disease development. Thus, primed immune expression against $P$. cucumerina is associated with coordinated potentiation of $\mathrm{H}_{2} \mathrm{O}_{2}$ and callose deposition. 


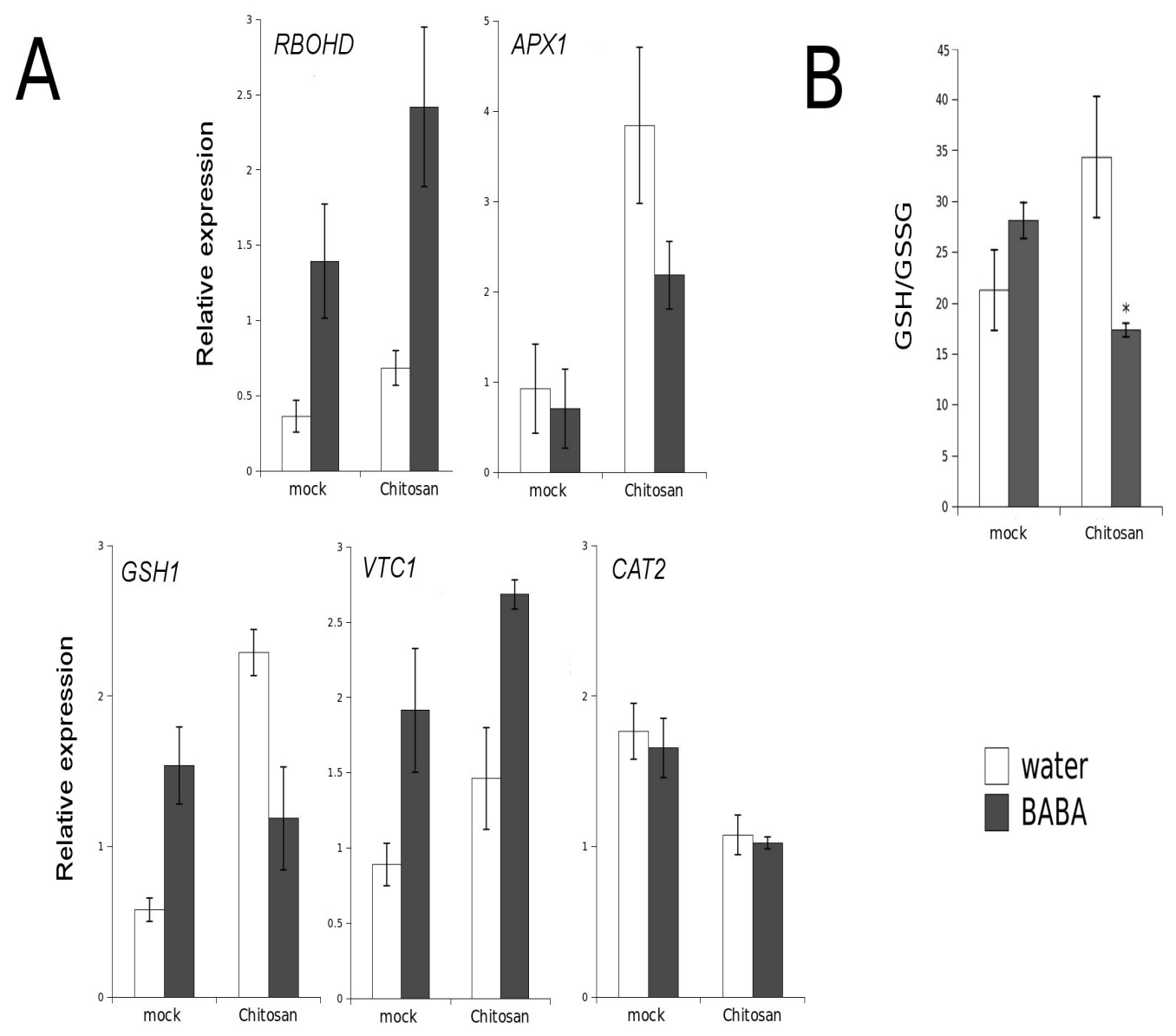

Figure 4: Effect of chitosan over genes implicated in ROS homeostasis and redox cell environment. A. Quantitative RT-PCR analysis of RBOHD, APX1, GSH1, VTC1 and CAT2 in seedlings 24h pretreated with BABA and after 24h of chitosan treatment. Bars represent mean $\pm \mathrm{SD}, \mathrm{n}=3$ independent replicates. B. Glutathione contents in Col- 0 seedlings treated as described above (A). Data shown are means \pm SD . Asterisk indicates statistically significant differences compared with water treated seedlings. (Student's $t$-test; $\alpha=0.05$ )

\section{$R B O H D$ and $G S H 1$ are critical for expression of primed immunity against $P$. cucumerina}

To investigate further the role of ROS homeostasis during expression of primed immunity against $P$. cucumerina, we tested rbohD, pad2, vtcl and cat 2 for BABA-IR, $\mathrm{H}_{2} \mathrm{O}_{2}$ production, and callose accumulation. As it is shown in Figure 6A, rbohD and pad2 failed to express BABA-IR against $P$. cucumerina, which coincided with lack of augmented production of $\mathrm{H}_{2} \mathrm{O}_{2}$ and callose. In contrast, the ROS scavenging mutants vtcl and cat 2 were unaffected in BABA-IR and expressed normal levels of basal resistance against the necrotroph (Figure 6A), even though they showed enhanced levels of $\mathrm{H}_{2} \mathrm{O}_{2}$ and callose deposition under all conditions tested (Figures 6B and 6C). Surprisingly, both mutants are impaired in priming of callose and $\mathrm{H}_{2} \mathrm{O}_{2}$. Unlike pad2, which behaves hypersensitive to $P$. cucumerina, the rbohD mutant expressed wild-type levels of basal resistance (Figure 6A). 
Hence, ROS production by RBOHD is necessary to mount a primed immune response, but is not required for basal resistance against P. cucumerina. GSH1, on the other hand, is necessary for both basal and primed immunity against $P$. cucumerina.

\section{BABA primes expression of $R B O H D$ while represses $A P X 1$ and $G S H 1$ favoring $\mathrm{H}_{2} \mathrm{O}_{2}$ accumulation.}

In a search of mechanisms that control BABA-IR we studied the behavior of the main genes involved in redox homeostasis upon P. cucumerina infection. We checked early responses generated after 48 and 72 hpi in plants pretreated with BABA 48 hours before the inoculation. Similarly to the in vitro system after chitosan challenge, we observed primed expression of $R B O H D$ and a strong inhibition of $A P X 1$ in BABA-treated plants after the infection by the necrotroph (Fig. 7). Surprisingly, GSHI transcripts are directly stimulated by BABA treatments while it is repressed after pathogen infection as it happened with chitosan challenges in vitro. The determination of the ratio GSH/GSSG at 48 and 72 hpi confirmed a shift into a more oxidized state in BABA-treated plants (Fig 7B). On the contrary, VTC1 shows a clear priming at $48 \mathrm{~h}$. Despite the increased levels of VTC1 in treated plants at early time points, the observation of $\mathrm{H}_{2} \mathrm{O}_{2}$ levels confirms that BABA manipulate the genes favoring the oxidized status versus genes participating in scavenging, since these genes are repressed or remain unchanged ( $A P X 1$ and $C A T 2$ respectively). The primed expression of $V T C 1$ may fit with this hypothesis as far as the ascorbic acid production that is catalyzed by this gene product could remain in other compartments acting as a reservoir to hold ROS under a toxic threshold. Accordingly, the effect of BABA on $C A T 2$ and $R B O H D$ genes is totally altered in pad2 (impaired in BABA-IR) and vtcl (altered in ROS homeostasis but intact in BABA-IR). While pad2 has lost RBOHD priming, the mutant vtc1 still shows activation by BABA (Fig S2). Interestingly, CAT2 is primed at late time-points in pad2 that may be explained by an attempt of the treated plant to overcome the massive stress imposed by its hypersensitive phenotype. In addition, CAT2 is strongly down-regulated by BABA in vtcl-treated plants upon infection, however its reduced transcription has not an impact on the already elevated production of $\mathrm{H}_{2} \mathrm{O}_{2}$ in non infected plants (Fig S3).

\section{Discussion}

The experimental evidences found in our results suggest that priming-mediated responses, can be an effective mechanism for plant protection and enhanced PAMP perception. It seems to function by increasing hydrogen peroxide and consequently enhancing callose accumulation. The mechanisms behind this primed responses are controlled by a specific tuning of the main genetic machinery of the cell implicated in ROS occurrence.

We previously demonstrated that in in vitro systems challenged with Flg22 and chitosan, $\mathrm{H}_{2} \mathrm{O}_{2}$ production is an event that takes place before callose accumulation (Luna et al., 2011). In the present study we have observed that primed responses are not functional in Arabidopsis treated with Flg22 while BABA induces strong increases of $\mathrm{H}_{2} \mathrm{O}_{2}$ and callose upon chitosan challenge. Although both events are connected, the regulation of plant responses upon fungal and bacterial PAMP is different. We demonstrate that mechanisms 
controlling primed callose and $\mathrm{H}_{2} \mathrm{O}_{2}$ accumulation differ from those regulated by basal responses. It was demonstrated that other priming inducers such as vitamin $\mathrm{B}_{1}$ induce resistance independently of JA, ET and ABA signalling pathways although it is dependent on NPRl and stimulates faster accumulation of $\mathrm{H}_{2} \mathrm{O}_{2}$ and callose (Ahn et al., 2007). Our results show that all the mutants tested impaired in either ROS generation or scavenging are functional in $\mathrm{H}_{2} \mathrm{O}_{2}$ and callose accumulation triggered by chitosan, however non of them display priming induced by BABA. Seemingly, Dubreuil-Maurizi et al (2010) demonstrated

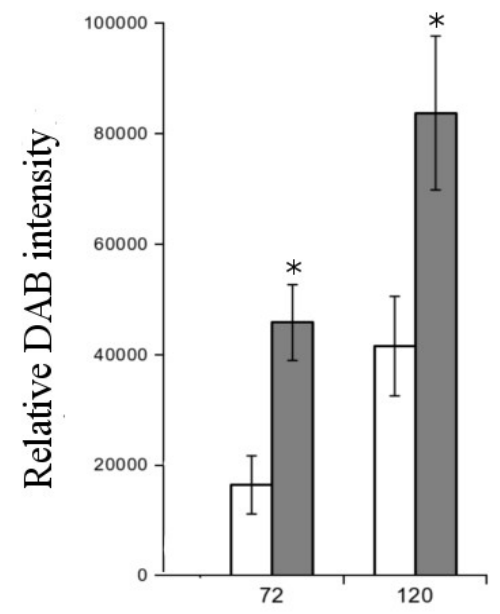

hpi
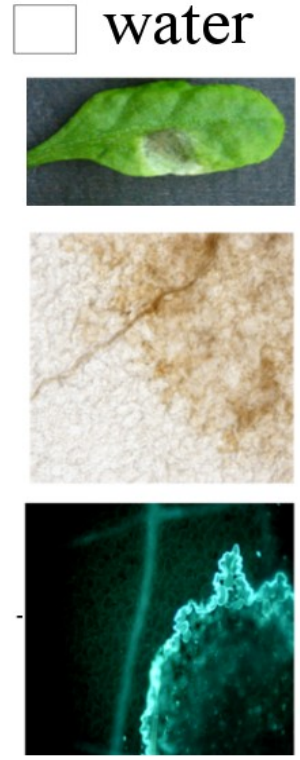

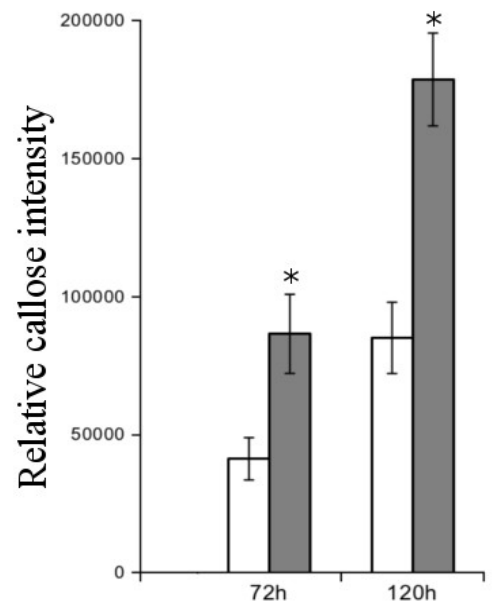

hpi
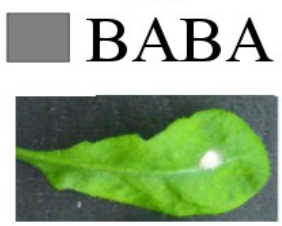

$\mathrm{H}_{2} \mathrm{O}_{2}$

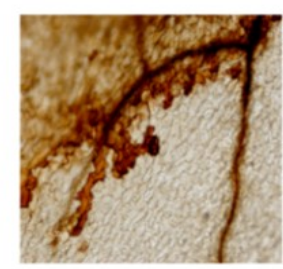

Callose

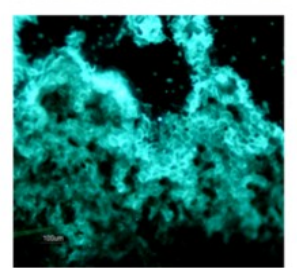

Figure 5: $\mathrm{H}_{2} \mathrm{O}_{2}$ and callose accumulation in water- and BABA- treated Col-0 plants upon inoculation by $P$. cucumerina . Five-week-old plants were soil-drenched with water or $150 \mu \mathrm{M}$ BABA. At 2 days after chemical treatment , 6-8 leaves per plant were challenged by applying $6 \mu \mathrm{l}$ droplets contanining $5.10^{6}$ spores $\mathrm{ml}^{-1}$. Quantification was performed by determining the number of brown pixels (DAB-staining) or yellow pixels (callose staining) on digital photographs of infected leaf areas at 72 and 120 hpi. Data shown are means \pm SD $(n=8)$ of the relative number of brown or yellow pixels per photograph. Asterisks indicate significant differences between water- and BABA- treated and infected plants. Below graphs there are representative leaves of Col-0 plants after inoculation with P. cucumerina in control plants (left) and BABA treated plants (right). 
that grape plants treated with DPI, a specific inhibitor of $R B O H D$, blocks BABA-IR against Plasmopara viticola. However there is no previous report of the implication of GSH1, CAT2 and $V T C 1$ in priming-mediated by BABA.

The levels of ROS and callose in the absence of challenge remain extremely low and they are not induced 24h after BABA treatments in in vitro MS medium, however in the presence of chitosan it is observed a dramatic increase of both plant responses. Contrastingly, when we determined the expression of the main genes involved in ROS metabolism, a direct induction of RBOHD, GSHI and VTCl after BABA treatments are found. It is clear that there must be downstream signalling events that control the output of priming since the final accumulation of $\mathrm{H}_{2} \mathrm{O}_{2}$ and callose needs the PAMP application or a pathogen challenge. This highlights again the benefits in fitness costs of the priming phenomenon (van Hulten et al., 2006). Despite vtc1 is considered as a priming mutant (Mukherkjee et al., 2010) it has reduced growth compared with the wild type plants (Veljovic-Jovanovic et al., 2001). Upon our experimental conditions this genotype displays enhanced levels of callose and $\mathrm{H}_{2} \mathrm{O}_{2}$ in the absence of PAMP challenge. Increased levels of ABA, SA, camalexin and $P R 1$ expression in the presence of the stress were also described in $v t c 1$. All this may be resposible for phenotypical growth costs (Pastori et al., 2003; Colville and Smirnoff, 2008; Barth et al., 2004). On the other hand, edrl and linl have been also considered as priming mutants (van Hulten et al., 2006; Camañes et al., 2012). Contrastingly, these mutants present normal growth and reduced levels of $P R-1$ and SA in the absence of challenge. Upon chitosan treatment both are active in $\mathrm{H}_{2} \mathrm{O}_{2}$ and callose accumulation and therefore they may share some common defence responses with BABA priming.

We have observed some defence responses in common when challenge the plants with chitosan or with the necrotroph $P$. cucumerina. Despite these shared elements, regulation of priming against pathogen involve specific events of redox homeostasis mediating priming against necrotrophs. BABA-induced priming against necrotrophs was demonstrated to be dependent on ABA-mediated callose deposition (Ton et al., 2004; Flors et al., 2008). In our results we have observed that BABA-IR against P. cucumerina is also dependent on $\mathrm{H}_{2} \mathrm{O}_{2}$ accumulation that has a direct influence on callose deposition. It is likely, therefore, that ABA, ROS and callose are all relevant signals controlling priming. The mutants rbohD and pad2 are impaired in $\mathrm{H}_{2} \mathrm{O}_{2}$ and callose priming and subsequently they do not display BABA-IR. The disruption of GSH1 in the mutant pad2, apparently, should have enhanced levels of $\mathrm{H}_{2} \mathrm{O}_{2}$ since it has a lower gluthatione production (Parisy et al., 2007). However, this mutant is impaired in cell membrane depolarization and this event takes place prior to ROS production which explain why pad2 accumulated such low levels of $\mathrm{H}_{2} \mathrm{O}_{2}$ (Dubreil-Mauciri et al., 2011) modifying its response to BABA priming. On the other hand, cat 2 and vtcl are also impaired in ROS and callose priming, even though they display an intact BABA-IR. Both accumulate very high levels callose and huge amounts of $\mathrm{H}_{2} \mathrm{O}_{2}$ that may still participate priming subsequent layers of defence which would explain the enhanced protection by BABA. Similar observations were obtained regarding to gene expression during priming induced by BABA in plants challenged either with chitosan or $P$. cucumerina. Noteworthy, priming and many other basal responses are multilayer phenomenons of horizontal resistance (Pastor et al., 2012). Gene regulation of redox homeostasis in priming suggests that the input of $\mathrm{H}_{2} \mathrm{O}_{2}$ is activated while the genes participating in some extent in ROS scavenging are unchanged or down-regulated. Although $R B O H D$ is basically generating superoxide, that is rapidly dismutated into $\mathrm{H}_{2} \mathrm{O}_{2}$ (Wojtaszek, 

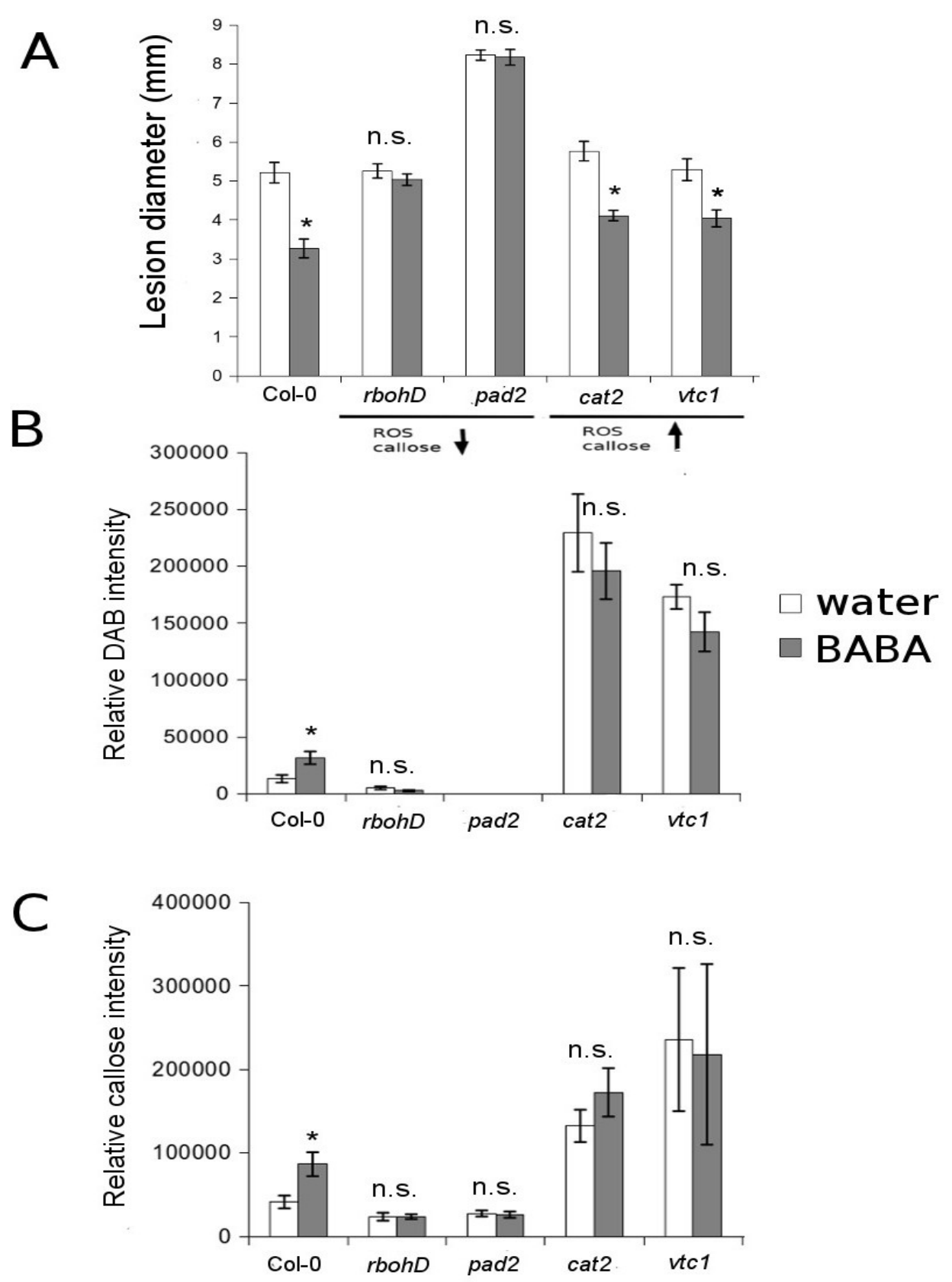

Figure 6: BABA-IR, $\mathrm{H}_{2} \mathrm{O}_{2}$ and callose accumulation in Col-0 and mutants in ROS homeostasis upon infection. A Lesion size in water- and BABA treated 5 week-old plants after 6 days post infection with $P$. cucumerina. Values are means and $\pm \mathrm{SD}(\mathrm{n}=15)$. For experimental details, see legend of figure 5. B DAB and $\mathbf{C}$ callose accumulation at $72 \mathrm{hpi}$ in water- and BABA-treated plants. Asterisks indicate significant differences between BABA-treated and infected respect to the water-treated and infected. Values are means and $\pm \mathrm{SD}(\mathrm{n}=8)$. n.s. $=$ no statistically significant difference between water- or BABA- treated and infected seedlings. (Student's t-test; $\alpha=0.05$ ). 

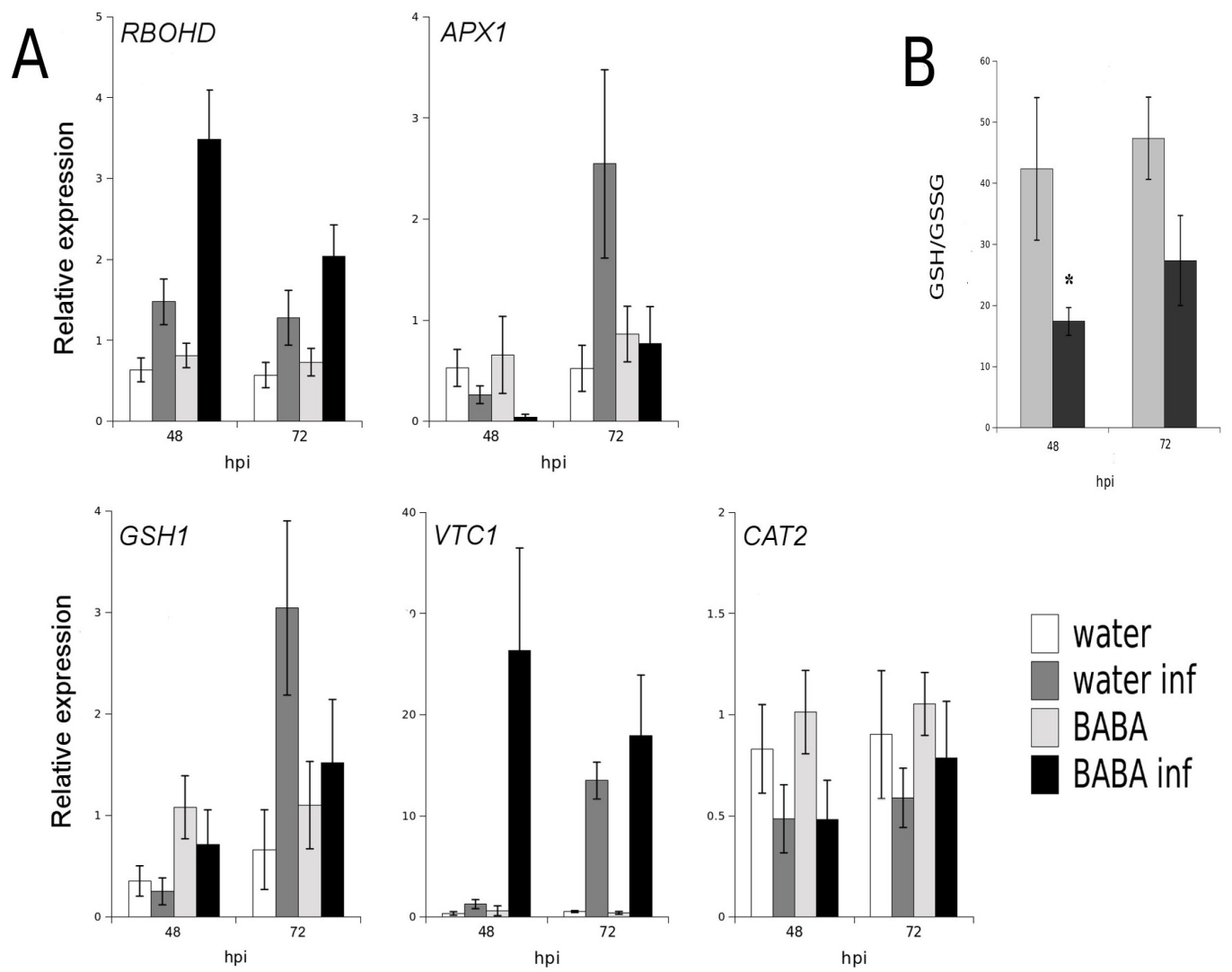

Figure 7: Priming effect in ROS homeostasis-implicated gene expression and GSH contents.

A. Quantitative RT-PCR analysis of RBOHD, APX1, GSH1, VTC1 and CAT2 in 5 weeks-old-plants pretreated with BABA 2 days before infection with P. cucumerina. RNA was isolated from infected leaves at 0,48 and 72 after inoculation, converted to cDNA and subjected to quantitative RT-PCR. Values are normalized at $\mathrm{t}=0 \mathrm{~h}$ (initial conditions). Bars represent mean $\pm \mathrm{SD}, \mathrm{n}$ $=3$ independent replicates. B. Glutathione contents in Col-0 seedlings treated as described above (A). Data shown are means \pm SD. Asterisk indicates statistically significant differences compared with water-treated seedlings.(Student's $t$-test; $\alpha=0.05$ ).

1997), consequently extracellular $\mathrm{H}_{2} \mathrm{O}_{2}$ is produced. This signal has been described to mediate the establishment of BABA-IR in Plasmopara viticola-vitis pathosystem, and the $R B O H D$ transcripts are also induced by BABA treatments and OG elicitation (DubreuilMaurizi et al., 2010). This oxidative burst potentiated by BABA could play an important role in signalling. Miller et al (2009) report a systemic signal propagation which is dependent of RBOHD, accompanied by an extracellular accumulation of ROS in distal locations from where the signal was initiated. So this gene emerge as an important component in cell-to-cell and long-distance communications, and so far, for primed responses in biotic stress. The mutant rbohD challenged with $P$. cucumerina showed wild type levels of disease while it was impaired in BABA-IR. Seemingly, it was described that untreated rbohD infected with Alternaria brassicicola or Botrytis cinerea did not displayed enhanced susceptibility (Galletti et al., 2008; Pogány et al., 2009), suggesting that $R B O H D$ is a mayor regulator of priming rather than basal defence responses against necrotrophs. In our research, BABA-induced $R B O H D$ expression may contribute to the enhanced levels of 
hydrogen peroxide that are maintained by a coordinated repression of $A P X 1$ that scavenge $\mathrm{H}_{2} \mathrm{O}_{2}$ similarly to CAT2, although APXs have higher affinity for $\mathrm{H}_{2} \mathrm{O}_{2}$ than CATs and therefore may play stronger influence in the final phenotypes (De Gara and Tommasi, 1999). The cytosolic isoform of $A P X 1$ is the most important in keeping redox control and homeostasis in the cell (Davletova et al., 2005). Noteworthy, during hypersensitive response VTC1 and APX1 are both down-regulated contributing to reach toxic increases of $\mathrm{H}_{2} \mathrm{O}_{2}$ that ends up with the cell death (de Pinto et al., 2006). In our results we have observed that priming stimulates an increase in $\mathrm{H}_{2} \mathrm{O}_{2}$, although it is not observed a $\mathrm{HR}$, that would negatively affect to defence responses against a necrotrophic pathogens. On the contrary, BABA down-regulates $A P X I$ transcripts while it primes at early time-points $R B O H D$, increasing the extracellular ROS production. Upon infection, BABA also primes $V T C 1$ expression. This may contribute to keep a remaining pool of ASA available for the cell to keep $\mathrm{H}_{2} \mathrm{O}_{2}$ at high concentrations but always under a toxic threshold level. High levels of $\mathrm{H}_{2} \mathrm{O}_{2}$ affect the redox status in the GSH pool more than in the ASA/DHA ratio and can easily shift to its oxidized form GSSG (Noctor, 2006; Noctor et al., 2012). In primed plants we have enhanced expression of VTCl but it does not correspond with increases in GSH1 transcripts. This gene regulation suggest an oxidized state of the cytoplasm induced by the high levels of $\mathrm{H}_{2} \mathrm{O}_{2}$, confirmed by lower levels of GHS/GSSG in BABA-treated plants upon PAMP challenge or infection. Noctor (2006) suggested that high level of oxidative status does not necessary correlate with toxic effects for the plant. Plants can support mild constitutive alteration of the glutathione redox state with no physiological costs (Mhamdi et al., 2010).

An appropriated ROS homeostasis is necessary for almost every cellular modification (Møller et al., 2008), and probably, for establishing cell-to-cell communications (Miller et al., 2009; Benitez-Alfonso and Jackson, 2009). In the absence of stress the plant is able to scavenge the excess of ROS produced by normal metabolism of the cell, but when a challenge is detected a boost of ROS is a common feature. Plants have evolved the ability to take advantage of these small molecules for signalling and defence. In the present work it is demonstrated that resistance mechanisms that involve redox homeostasis and callose deposition are differentially regulated during basal and primed defence responses. For primed responses to PAMPs it is necessary to have intact the genetic machinery that participates in hydrogen peroxide generation or scavenging, while the primed responses against the necrotrophic pathogen $P$. cucumerina mainly stands on RBOHD and GSH1. The role of both genes in priming induced by BABA against fungi follows different patterns. While BABA induction of $R B O H D$ contributes to enhanced $\mathrm{H}_{2} \mathrm{O}_{2}$ accumulation, the role of GSH1 is less obvious. Its participation in priming seems to be independent of glucosinolates (data not shown). However, GSH1 is contributing to a particular tuning of GSH/GSSG that remains at lower levels upon priming, while other genes participating in ROS homeostasis also contribute to this balance. The present research demonstrates that ROS are essential for callose-rich papillae depositions in BABA priming and they are probably linked to ABA mediated priming against necrotrophic pathogens (Flors et al., 2008; Luna et al., 2011), although this last statement needs further verification. 


\section{Materials and Methods}

\section{Plant material, growth conditions and chemical treatments}

For in vitro assays, seeds of Arabidopsis thaliana accesion Col-0 and mutants in this background, rbohD (SALK_070610), pad2 (Parisy et al 2007), cat2 (Bueso et al 2007), vtc1 (Conklin et al 2000), pen2-2 (Lipka et al 2005) were vapour-phase sterilised for 4 to $6 \mathrm{~h}$ (http://entomology.wisc.edu/ afb/vapster.html). Approximately, 15 sterilized seeds were sown per well in sterile 12-well plates, each containing $1 \mathrm{ml}$ of sterilized basal MS medium without Gambor's vitamins (Duchefa) with $1 \%$ of sucrose. All growth media were supplemented with $0.5 \%$ of morpholineethane-sulfonic acid hydrate (MES; Sigma) with final $\mathrm{pH}=5.7$ to 5.8. Seedlings were cultivated under standard growth conditions (16-h-day and 8-h-night cycle, $20^{\circ} \mathrm{C}$ and $17^{\circ} \mathrm{C}$ respectively) at $150 \mu \mathrm{M} \mathrm{m}^{-2} \mathrm{sec}^{-1}$. After 7 days of growth, MS medium was replaced by fresh MS medium. At day 8, BABA (Sigma) 1 ppm, was applied as a final concentration. After 24 hours of BABA treatment seedlings were challenged by $1 \mu \mathrm{M}$ of Flg22 (GenScript, Piscataway, NJ, U.S.A.) and or $0.01 \%$ (wt $/ \mathrm{vol}$ ) low-viscous chitosan (Fluka, Milwaukee, WI, U.S.A.) as a final concentrations which has a molecular weight of appximately $150 \mathrm{kDa}$ and a 95 to $99.8 \%$ degree of acetylation (Hombach and Bernkop-Schnürch 2009). Mock treatments were performed by addition of sterlized-destilated water at the same volume as the PAMPs treatments. At day 9, the samples were collected for analysis.

Experiments with adult plants were performed as follows: seeds of Col-0 and mutants, were sown in jiffy-7 peat pellets (Clause-Tezier Ibérica, http://www.clausetezier.com/). Plants were grown in a growth phytochamber with 100-150 $\mu \mathrm{M} \mathrm{m}^{-2} \mathrm{sec}^{-1}$ at $21^{\circ} \mathrm{C}$ and $19^{\circ} \mathrm{C}$ under $9 \mathrm{~h}$ light/dark cycles and $65 \%$ humidity. Five week old plants were pretreated with $150 \mu \mathrm{M}$ of BABA.

\section{Callose and $\mathrm{H}_{2} \mathrm{O}_{2}$ determination, microscopy analysis and quantification}

For in vitro staining experiments, aniline-blue and by 3,3'-diaminobenzidine (DAB) were used to determine callose and $\mathrm{H}_{2} \mathrm{O}_{2}$ levels as described in Luna et al. (2011). In adult plants leaves were sampled 3 days post infection. For in adult plants callose staining in aniline-blue was performed as described in Ton and Mauch-Mani (2004). For DAB staining, leaves were cut and put immediately in $1 \mathrm{mg} / \mathrm{ml}$ of $\mathrm{DAB}$, subsequently, leaves were destained in $96 \%$ ethanol and rehydrated in glicerol $60 \%$. Callose was visualized by epifluorescence microscope with UV filter and $\mathrm{H}_{2} \mathrm{O}_{2}$ by bright field microscopy.

\section{Plectosphaerella cucumerina bioassays and culture}

Five-week old plants were soil-drenched with water (control) or a $150 \mu \mathrm{M}$ of BABA as a final concentration, $48 \mathrm{~h}$ prior to infection. Then, plants were challenged by $6 \mu \mathrm{l}$ drops of $5 \times 10^{6}$ spores $\mathrm{ml}^{-1}$ to fully expanded leaves. Plants were maintained at $100 \%$ relative humidity. Disease symptoms were evaluated by determining the average of lesion diameter in 20-30 plants per treatment and time point, at 7 days after inoculation. These experiments were repeated at least three times with similar results. 


\section{Quantitative real-time RT-PCR analysis of transcripts}

Gene expression by quantitative real-time RT-PCR was performed using RNA samples extracted from leaf tissue using E.Z.N.A. ${ }^{\mathrm{TM}}$ Plant RNA Kit OMEGA bio-tek (www.omegabiotek.com). Arabidopsis leaf tissues samples for RNA isolation were collected at 0,48 and 72 hours after inoculation. Leaf tissue from eight plants were collected. For quantitative real-time $1.5 \mu \mathrm{g}$ of total RNA was digested using 1 unit of RQ1 Rnase-Free Dnase buffer and up to $10 \mu \mathrm{l}$ of Mili-Q water, and incubated for $30 \mathrm{~min}$ at $37^{\circ} \mathrm{C}$. After incubation, $1 \mu \mathrm{l}$ of RQ1 Dnase stop buffer was added, and the solution was incubated again at $65^{\circ} \mathrm{C}$ for $10 \mathrm{~min}$ to inactivate the Dnase. Highly pure RNA was used for the RT reaction. The RT reaction was performed by adding $2 \mu \mathrm{l}$ of RT buffer, $2 \mu \mathrm{l}$ of $5 \mathrm{mM}$ dNTP, $2 \mu \mathrm{l}$ of 10 $\mu \mathrm{M}$ Oligo (dT)15 primer (Promega), $1 \mu \mathrm{l}$ of $\mathrm{U} \mu \mathrm{l}-1$ Rnasin inhibitor (Promega) and $1 \mu \mathrm{l}$ of Omniscript reverse transcriptase (Quiagen, http://www.qiagen.com). The reaction mixture was incubated at $37^{\circ} \mathrm{C}$ for $60^{\circ} \mathrm{C}$. Less than $10 \%$ of the volume of the RT reaction was used for the quantitative PCR. A melting curve analysis was performed at the end of PCR reaction to confirm the product purity. The list of primers are in supplemental material. Values are normalized with GAPDH3 expression in the same sample, using the $2^{\Delta \mathrm{Ct}}$ method, where $\Delta \mathrm{Ct}=\mathrm{Ct}($ reference gene) $-\mathrm{Ct}$ (gene of interest). Fold induction values of gene expression were normalized to values relative to Col-0 water or Col-0 BABA at $0 \mathrm{~h}$ before infection. The experiments were repeated with At $\lg 13320$ with similar results.

\section{Determination of GSH and GSSG.}

GSH and GSSG were extracted and quantified as described in Rellán-Álvarez et al (2006) with some modifications. Briefly, we use for quantification of both compounds LCESI tandem mass spectrometry coupled to a triple quadrupole (TQD, Waters, Manchester) in positive mode, using hGSH as a internal standard. The LC separation was performed using an Acquity UPLC BEH C18 analytical column, $1.7 \mathrm{~mm}$ particle size, $2.150 \mathrm{~mm}$ (Waters).

\section{References}

Ahn I., Kim S., Lee Y., Suh S., (2007). Vitamin $B_{1}$-Induced Priming Is Dependent on Hydrogen Peroxide and the NPRI gene in Arabidopsis. Plant Physiol. 143, 838-848.

Apel K., Hirt H., 2004. Reactive Oxygen species: Metabolism, oxidative stress, and signal transduction. Annu. Rev. Biol. 55:373-99

Arrigoni O., De Tullio MC., (2002). Ascorbic acid: much more than just an antioxidant. Biochimica et Biophysica Acta 1569, 1-9.

Barth C., Moeder W., Klessig D.F., Conklin P.L., (2004). The timing of senescence and response to pathogens is altered in the ascorbate-deficient arabidopsis mutant vitamin c-1. Plant Phys 134, 1784-1792.

Beckers, G.J.M., Jaskiewicz, M., Liu, Y., Underwood, W.R., He, S.Y., Zhang, S., Conrath, U., 2009. Mitogen-Activated Protein Kinases 3 and 6 Are Required for Full Priming of Stress Responses in Arabidopsis thaliana. Plant Cell 21, 944-953.

Benitez-Alfonso Y., Jackson D., 2009. Redox homeostasis regulates plasmodesmal communication in Arabidopsis meristems. Plant, signallingand Behavior 4, 655-659.

Bent A., Mackey D., (2007). Elicitors, effectors, and R genes: the new paradigm and a lifetime supply of questions. Annu. Rev. Phytopathol. 45, 399-436. 
Boller T., Felix G., (2009). A renaissance of elicitors: perception of microbe-associated molecular patterns and danger signals by pattern-recognition receptors. Annu. Rev Plany Biol 60, 379-406.

Bueso E., Alejandro S., Carbonell P., Perez-Amador M.A., Fayos J., Bellés J.M., Rodríguez P.L., Serrano R., (2007): The lithium tolerance of the Arabidopsis cat 2 mutant reveals a cross-talk between oxidative stress and ethylene. Plant Journal 52:10521065.

Camañes G., Pastor V., Cerezo M., García-Andrade J., Vicedo B., García-Agustín P., Flors V., (2012). A deletion in NRT2.1 Attenutes Pseudomonas syringae-induced hormonal perturbation, resulting in primed plant defences. Plant Phys 158, 10541066.

Colville L., Smirnoff N., 2008: Antioxidant status, peroxidase activity and PR protein transcript levels in ascorbate-deficient Arabidopsis thaliana vtc mutants. 59, 38573868.

Conklin P. L., Barth C., 2004. Ascorbic acid, a familiar small molecule interwined in the response of plants to ozone, pathogens, and the onset of senescence. Plant, Cell and Environment 27, 959-970.

Conklin P. L., Saracco S. A., Norris S. R., Last R. L., 2000: Identification of ascorbic aciddeficient Arabidopsis thaliana mutants. Genetics 154, 847-856.

Conrath U., 2011. Molecular aspects of defence priming. Trends Plant Sci. 16, 524-531.

D'Autréaux B., Toledano M. B., 2007: ROS as signalling molecules: mechanisms that generate specificity in ROS homeostasis. Molecular cell biology 8, 813-824.

Davletova S., Rizhsky L., Liang H., Shengqiang Z., Oliver D. J., Coutu J., Shulaev V., Schlauch K., Mittler R., 2005: Cytosolic ascorbate peroxidase 1 is a central component of the reactive oxygen gene network in Arabidopsis. The Plant Cell $17,268-281$.

De Gara L., de Pinto M. C., Tommasi F., 2003: The antioxidant vis-à-vis reactive oxygen species during plant-pathogen interaction. Plant Physiology and Biochemistry 4, 863-870.

De Gara, L., Tommasi, F., 1999. Ascorbate redox enzymes: a network of reaction involved in plant development. Recent Res. Dev. Phytochem. 3, 1-15.

De Pinto M. C., Paradiso A., Leonetti P., De Gara L., 2006. Hydrogen peroxide, nitric oxide and cytosolic ascorbate peroxidase at the crossroad between defence and cell death. Plant J. 48, 784-795.

Desikan R., Horák J., Chaban C., Mira-Rodado V., Witthöft J., Elgass K., Grefen C., Cheung M.K., Meixner A.J., Hoolev R., Neill S. J.,Hancok J. T., Harter K., 2008; The histidine kinase AHK5 integrates endogenous and environmental signals in Arabidopsis guard cells. PloS One 3, Issue 6, e2491 (1-15)

Dubreuil-Maurizi C., Trouvelot S., Frettinger P., Pugin A., Wendehenne D., Poinssot B., 2010: $\beta$-aminobutyric acid primes and NADPH oxidase-dependent reactive oxygen species production during grapevine-triggered immunity. MPMI 23, 1012-1021.

Dubreuil-Maurizi C., Vitecek J., Marty L., Branciard L., Frettinger P., Wendehenne D., Meyer A. J., Mauch F., Poinssot B., 2011. Glutathione deficiency of the Arabidopsis mutants pad2-1 affects oxidative stress-related events, defence gene expression, and the hypersensityve response. Plant Physiol 157, 2000-2012.

Felix G., Duran J. D., Volko S., Boller T., 1999. Plants have a sensitive perception system for the most conserved domain of bacterial flagellin. Plant J. 18:265-76

Flors V., Ton J., van Doorn R., Jakab G., García-Agustín P., Mauch-Mani B., 2008. Interplay between JA, SA, and $\mathrm{ABA}$ signalling during basal and induced resistance 
against Pseudomonas syringae and Alternaria brassicicola.. Plant Journal 54: 8192.

Foyer C.H., Noctor G., 2005a: Redox homeostasis and antioxidant signalling: a metabolic interface between stress perception and physiological responses. Plant Cell 17, 1866-1875.

Foyer C.H., Noctor G., 2005b: Oxidant and antioxidant signalling in plants: a re-evaluation of the concept of oxidative stress in a physiological context. Plant, Cell and Environment 28, 1056-1071.

Friedrich L., Lawton K., Ruess W., Masner P., Specker N., Gut Rella M., meier B., Dincher S., Staub T., Ukness S., Métraux J. P., Kessmann H., Ryals J., 2003. A benzothiadiazole derivative induces systemic acquired resistance in tobacco. The plant Journal 10, 31-70.

Gadjev I., Vanderauwera S., Gechev T. S., Laloi C., Minkov I. N., Shulaev V., Apel K., Inzé D., Mittler R., Breusegem F.V., 2006: Transcriptomic footprints disclose specificity of reactive oxygen species signallingin Arabidopsis. Plant Phys 141, 436-445.

Galletti, R., Denoux, C., Gambetta, S., Dewdney, J., Ausubel, F. M., DeLorenzo, G., and Ferrari, S. 2008. The AtrbohD-mediated oxidative burst elicited by oligogalacturonides in Arabidopsis is dispensable forthe activation of defence responses effective against Botrytis cinerea. Plant Physiol. 148:1695-1706

Gechev T. S., Hille J., 2005: Hydrogen peroxide as a signal controlling plant programmed cell death. J. Cell Biol. 168, 17-20.

Ghanta S., Chattopadhyay S., 2011: Glutathione as a signalling molecule. Another challenge to pathogens. Plant Signalling and Behavior 6, 783-788.

Ghanta S., Bhattacharyya D., Sinha R., Banerjee A., Chattopadahyay S., 2011: Nicotiana tabacum overexpressing gamma-ECS exhibits biotic stress tolerance likely through NPR1-dependent salicylic acid mediated pathway. Planta 233, 895-910.

Gomez-Gomez, L., Boller T., 2000. FLS2: An LRR receptor-like kinase involved in the perception of the bacterial elicitor flagellin in Arabidopsis. Molecular Cell 5:1003-1012.

Hancock J., Desikan R., Harrison J., Bright J., Hooley R., Neill S., 2006: Doing the unexpected: proteins involved in hydrogen peroxide perception. Journal of Experimental botany 57, 1711-1718.

Iritri M., Faoro F., 2009. Chitosan as a MAMP, searching for a PRR. Plant, signalling\& Behavior 4, 66-68.

Ishikawa T., Shigeoka S., 2008. Recent advances in ascorbate biosynthesis and the physiological significance of ascorbate peroxidase in photosynthesizing organisms. Bioscience Biotechnology and Biochemistry 72, 1143-1154.

Jakab G., Cottier V., Toquin V., Rigoli G., Zimmerli L., Metraux J.P., Mauch-Mani B., 2001. beta-Aminobutyric acid-induced resistance in plants. Eur. J. Plant Pathol. 107, 2937.

Jakab G., Ton J., Flors V., Zimmerli L., Metraux J., Mauch-Mani B., 2005. Enhancing Arabidopsis salt and drought stress tolerance by chemical priming for its abscisic acid responses. Plant Physiol. 139, 267-274.

Jonak C., Okrész L., Bögre L., Hirt H., 2002; Complexity, cross-talk and integration of plant MAP kinase signaling. Curr. Opin. Plant Biol. 5, 415-424.

Jones J.D.G., Dangl J.L., 2006. The plant immune system. Nature 444, 323-329.

Kessmann H., Staub T., Hofmann C., Maetzke T., Herzog J., Ward E., Uknes S., Ryals J., 1994: Induction of systemic acquired resistance in plants by chemicals. Annu. Review of Phytopathology, 32, 439-459. 
Koussevitzky S., Suzuki N., Huntington S., Armijo L., Sha W., Cortes D., Shulaev V., Mittler R., 2008. Ascorbate peroxidase 1 plays a key role in the response of Arabidopsis thaliana to stress combination. J. Biological Chemistry 283, 3419734203.

Laloi C., Apel K., Danon A., 2004. Reactive oxygen signalling: the latest news. Current Opinion in Plant Biology 7, 323-328.

Laloi C., Stachowiak M., Pers-Kamczyc E., Warzy E., Murgia I., Apel K., 2007. Cross-talk between singlet oxygen- and hydrogen peroxide-dependent signallingof stress responses in Arabidopsis thaliana. Proc. Natl. Acad. Sci. USA 104, 672-677.

Lamb C., Dixon R. A., 1997: The oxidative burst in plant disease resistance. Annu Rev Plant Physiol Plant Mol. Biol. 48, 251-275.

Lipka V., Dittgen J., Bednarek P., Bhat R., Wiermer M., Stein M., Landtag J., Brandt W., Rosahl S., Scheel D., Llorente F., Molina A., Parker J., Somerville S., SchulzeLefert, P. 2005. Pre- and postinvasion defences both contribute to nonhost resistance in Arabidopsis. Science 310:1180-3.

Luna E., Pastor V., Robert J., Flors V., Mauch-Mani B., Ton J., 2011. Callose Deposition: A Multifaceted Plant defence Response. Mol. Plant-Microbe Interact. 24, 183-193.

Luna, E., Bruce TJA, Roberts MR, Flors V, Ton J., 2012. Next Generation Systemic Acquired Resistance. Plant Phys 158, 844-853.

Meng L., Wong J. H., Feldman L. J., Lemaux P. G., Buchanan B. B., 2010: A membraneassociated thioredoxin required for plant growth moves from cell to cell, suggestive of a role in intercellular communication. PNAS 107, 3900-3905.

Miller G., Suzuki N., Rizhsky L., Hegie A., Koussevitzky S., Mittler R., 2007: Double mutants deficient in cytosolic and thylakoid ascorbate peroxidase reveal a complex mode of interaction between reactive oxygen species, plant development, and response to abiotic stress. Plant Physiol. 144,1777-1785.

Miller G., Schlauch K., Tam R., Cortes D., Torres M. A., Shulaev V., Dangl J. L., Mittler R., 2009: The plant NADPH oxidase RBOHD mediates rapid systemic signallingin response to diverse stimuli. Sci. Signal. 2, ra45.

Mittler, R., Vanderauwera, S., Suzuki, N., Miller, G., Tognetti, V.B., Vandepoele, K., Gollery, M., Shulaev, V., Van Breusegem, F., 2011. ROS signalling: the new wave?. Trends Plant Sci. 16, 300-309.

Møller I. M., Jensen P. E., Hansson A., 2008. Oxidative modifications to cellular components in plants. Annu. Rev. Plant Biol. 58, 459-481.

Mou Z., Fan W., Dong X., 2003: Inducers of plant systemic acquired resistance regulate NPR1 function through redox changes. Cell 113, 935-944.

Mukherjee, M., Larrimore, K.E., Ahmed, N.J., Bedick, T.S., Barghouthi, N.T., Traw, M.B., Barth, C., 2010. Ascorbic Acid Deficiency in Arabidopsis Induces Constitutive Priming That is Dependent on Hydrogen Peroxide, Salicylic acid, and the NPRI gene. MPMI 23, 340-351.

Neill, S., Desikan, R., Hancock, J., 2002. Hydrogen peroxide signalling. Current Opinion in Plant Biology 5, 388-395.

Noctor G., 2006. Metabolic signalling in defence and stress: the central roles of soluble redox couples. Plant, Cell and Environment 29, 409-425.

Noctor G., Mhamdi A., Chaouch S., Han Y., Neukermans J., Queval G., Foyer C. H., 2012. Glutathione in plants: an integrated overview. Plant, Cell and Environment 35, 454484.

Parisy V., Poinssot B., Owsianowski L., Buchala A., Glazebrook J., Mauch F., 2007. Identification of PAD2 as a gamma-glutamylcysteine synthetase highlights the 
importance of glutathion in disease resistance of Arabidopsis. Plant J 49, 159-172.

Pastor V., Luna E., Mauch- Mani B., Ton J., Flors V., 2012. Primed plants do not forget. Environ. Exp. Bot. doi:10.1016/j.envexpbot.2012.02.013

Pastori G. M., kiddle G., Antoniw J., Bernard S., Veljovic-Jovanovic S., Verrier P. J., Noctor G., Foyer C. H., 2003: Leaf vitamin C contents modulate plant defence transcripts and regulate genes that control development through hormone signalling. The Plant Cell, 15, 939-951.

Pei Z. M., Murata Y., Benning G., Thomine S., Klüsener B., Allen G. J., Grill E., Schroeder J. I., 2000: Calcium channels activated by hydrogen peroxide mediate abscisic acid signalling in guard cells. Nature 406, 731-734.

Pnueli L., Liang H., Rozenberg M., Mittler R., 2003: Growth suppression, altered stomatal response, and augmented induction of heat shock proteins in cytosolic ascorbate peroxidase (Apxl)- deficient Arabidopsis plants. Plan J. 34, 187-203.

Pogany M, von Rad U, Grun S, Dongo A, Pintye A., 2009. Dual Roles of Reactive Oxygen Species and NADPH Oxidase RBOHD in an Arabidopsis-Alternaria Pathosystem. Plant Physiol 151, 1459-1475.

Pozo, M.J., Van Der Ent, S., Van Loon, L.C., Pieterse, C.M.J., 2008. Transcription factor MYC2 is involved in priming for enhanced defence during rhizobacteria-induced systemic resistance in Arabidopsis thaliana RID A-9326-2011. New Phytol. 180, 511-523.

Queval G., Jaillard D., Zechmann B., Noctor G., 2011. Increased intracellular H2O2 availability preferentially drives glutathione accumulation in vacuoles and chloroplast. Plant, Cell and Environment 34, 21-32.

Rasmann. S., De Vos, M., Casteel, C.L., Tian, D., Halitschke. R., Sun. J.Y., Agrawal. A.A., Felton, G.W., Jander. G., 2012. Herbivory in the previous generation primes Arabidopsis and tomato for enhanced insect resistance. Plant Physiol 158, 854-63.

Rellán-Álvarez R., Hernández L. E., Abadia J., Alvarez-Fernández A., 2006. Direct and simultaneous determination of reduced and oxidized glutathione and homoglutathione by liquid chromatography-electrospray/mass spectrometry in plant tissue extracts. Analytical Biochemistry 356, 254-264.

Slaughter A., Daniel X., Flors V., Luna E., Hohn E., Mauch-Mani, B., 2012. Descendants of primed Arabidopsis plants exhibit resistance to biotic stress. Plant Physiol. 158, 835-843.

Spoel S. H., Tada Y., Loake G.J., 2010: Post-translational protein modification as a tool for transcription reprogramming. New Phytologist 186:333-339

Spoel S. H. and Loake G. J., 2011: Redox-based protein modifications: the missing link in plant immune signalling. Current Opinion in Plant Biology 14, 358-364.

Tada Y., Spoel SH, Pajerowska-Mukhtar K., Mou Z, Song, J., Wang C., Zuo J., Dong X., 2008: Plant immunity requires conformational charges of NPR1 via S-nitrosylation and thioredoxins. Science 321:952-956.

Ton, J., Jakab, G., Toquin, V., Flors, V., Iavicoli, A., Maeder, M.N., Metraux, J.P., MauchMani, B., 2005. Dissecting the beta-aminobutyric acid-induced priming phenomenon in Arabidopsis. Plant Cell 17, 987-999.

Ton J., Mauch-Mani B., 2004. Beta-amino-butyric acid-induced resistance against necrotrophic pathogens is based on ABA-dependent priming for callose. Plant $\mathrm{J} 38$ : 119-130.

Torres M. A., Dangl J. L., Jones J. D., 2002. Arabidopsis gp91 ${ }^{\text {phox }}$ homologues AtrbohD and AtrbohF are required for accumulation of reactive oxygen intermediates in the plant defence response. PNAS 99, 517-522. 
Tsauda K., Katagiri F., 2010. Comparing signallingmechanisms engaged in pattern-triggered and effector-triggered immunity. Curr. Opn Plant Biol 13, 459-465.

van der Ent, S., Van Hulten, M., Pozo, M.J., Czechowski, T., Udvardi, M.K., Pieterse, C.M.J., Ton, J., 2009. Priming of plant innate immunity by rhizobacteria and betaaminobutyric acid: differences and similarities in regulation RID A-9326-2011. New Phytol. 183, 419-431.

van Hulten, M., Pelser, M., van Loon, L., Pieterse, C., Ton, J., 2006. Costs and benefits of priming for defence in Arabidopsis RID A-9326-2011. Proc. Natl. Acad. Sci. U. S. A. 103, 5602-5607.

Veljovic-Jovanovic S. D., Pignocchi C., Noctor G., Foyer C. H., 2001. Low ascorbic acid in the vtc-lmutant of Arabidopsis is associated with decreased growth and intracellular redistribution of the antioxidant system. Plant Physiol. 127, 426-435.

Wheeler G. L., Jones M. A., Smirnoff N., 1998. The biosynthetic pathway of vitamin C in higher plants. Nature 393, 365-369.

Wojtaszek P., 1997. Oxidative burst: an early plant response to pathogen infection. Biochem. J. 332, 681-692

Zimmerli L., Jakab G., Métraux J-P., Mauch-Mani B., 2000. Potentiation of pathogenspecific defence mechanisms in Arabidopsis by b-aminobutyric acid. Proceedings of the National Academy of Sciences of the United States of America 97: 12920-12925.

Zipfel C., 2009. Early molecular events in PAMP-triggered immunity. Current opinion 12, 414-420. 


\section{Supplementary material}
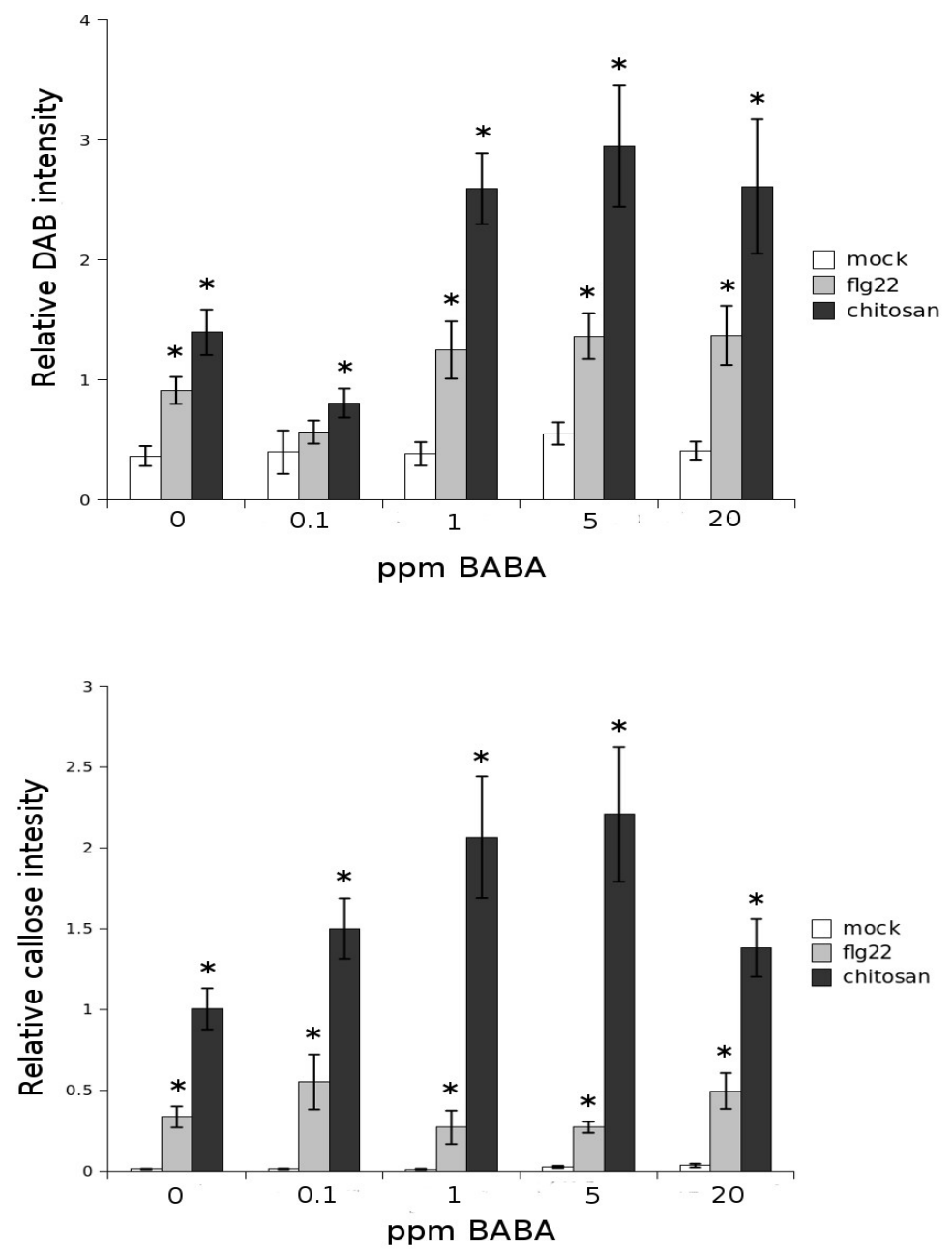

Figure S1: Dose-response of callose and $\mathrm{H}_{2} \mathrm{O}_{2}$ accumulation in cotyledons pretreated with BABA 24 before PAMP treatment. Callose and DAB intensity was determined as number of callose and DAB corresponding pixels relative to the number of pixels corresponding to plant material. Asterisks indicates statistically significant differences compared with mock control plants. 

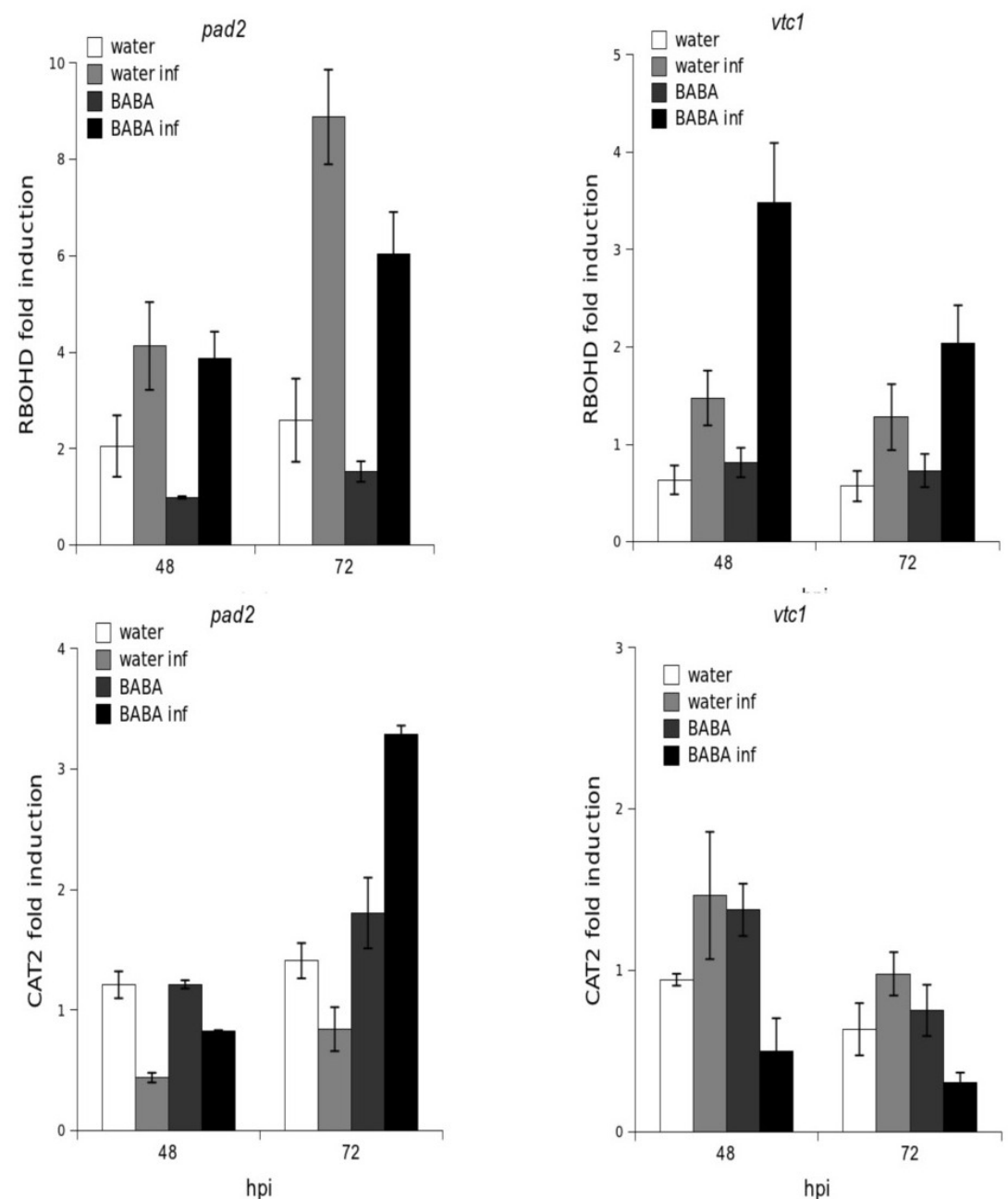

vtc1

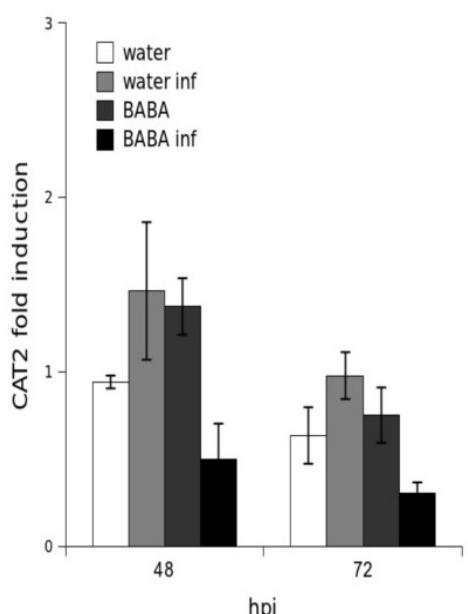

Figure S2: Quantitative RT-PCR analysis of $R B O H D$ and $C A T 2$ in 5 weeks-old-mutants plants pad2 and vtc1 pretreated with BABA 2 days before infection. RNA was isolated from infected leaves at 0,48 and 72 after inoculation, converted to cDNA and subjected to quantitative RT-PCR. Values are normalized at $\mathrm{t}=0 \mathrm{~h}$ (initial conditions). Bars represent mean $\pm \mathrm{SD}, \mathrm{n}$ $=3$ independent replicates. 
Table S1: Primers used for RT-qPCR analysis of gene expression.

\begin{tabular}{|l|l|}
\hline$A P X 1 \mathrm{fw}$ & GTCCATTCGGAACAATGAGGTTTGAC \\
\hline APX1 rev & GTGGGCACCAGATAAAGCGACAAT \\
\hline$V T C 1 \mathrm{fw}$ & CACTCGCTTGAGACCATTGA \\
\hline$V T C 1 \mathrm{rev}$ & CCTAGTGGCTCGGTCTCTTG \\
\hline$R B O H D \mathrm{fw}$ & AGGACACCTATGAGCCGATG \\
\hline RBOHD rev & CAACCATCACAATGCCAG \\
\hline GSH1 fw & GTGTGCCCTGCCAGCTTTCT \\
\hline GSH1 rev & CAGGACATCTTCAGCGACATGC \\
\hline$C A T 2 \mathrm{fw}$ & CGAGGTATGACCAGGTTCGT \\
\hline$C A T 2 \mathrm{rev}$ & CTTCCAGGCTCCTTGAAGTTG \\
\hline At1g13320 fw & TAACGTGGGCAAAATGATG \\
\hline At $1 \mathrm{~g} 13320 \mathrm{rev}$ & GTTCTCCACAACCGCTTGGT \\
\hline GAPDH3 fw & TTGGTGACAACAGGTCAAGCA \\
\hline GAPDH3 rev & AAACTTGTCGCTCAATGCAATC \\
\hline
\end{tabular}




\section{CHAPTER 4}

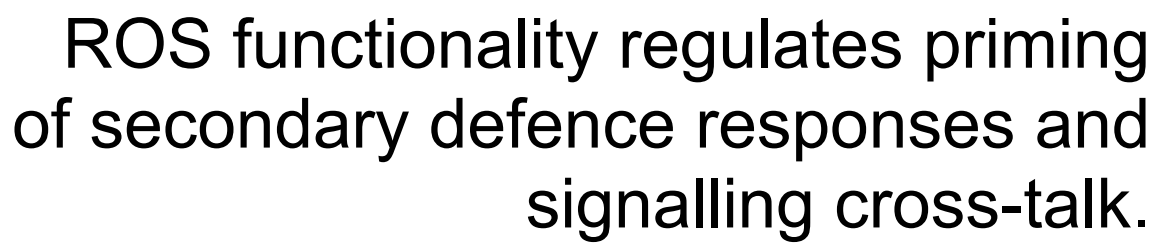




\begin{abstract}
Induced resistance against Plectosphaerella cucumerina is mediated by primed accumulation of callose and $\mathrm{H}_{2} \mathrm{O}_{2}$. The mechanisms that regulate primed responses follow different signalling pathways when the preconditioning takes place in mutants that express constitutive priming or when it is induced by the nonprotein aminoacid $\beta$-aminobutyric acid. In priming mutants induced resistance is mediated by an interplay between JA, ABA and callose. Contrastingly, BABAinduced resistance involves a fine tuning of ROS homoeostasis and ABA, while it is independent of SA- and JA-signalling. Despite this regulation, Col-0 plants treated with BABA also shows priming of SA-signalling and the oxylipin OPDA. This observations suggest that other dispensable signals can also be induced, probably as reminiscences of the still intact basal defence responses during priming. Thus, during the multilayer phenomenon of priming essential and dispensable signals can be enhanced. The $v t c 1$ mutant is altered in ROS homeostasis, therefore it fails to perceive BABA-induced priming of $\mathrm{H}_{2} \mathrm{O}_{2}$ and callose. Surprisingly, it is protected against $P$. cucumerina. Despite BABA treatments results in a down-regulation of camalexin, $v t c 1$ displays enhanced basal levels and its camalexin levels dramatically increase after BABA treatment upon infection. This finding suggests that subsequent late layer of defences can be primed when some dispensable priming signals are altered or non functional.
\end{abstract}




\section{Introduction}

Plants can overcome pathogen attack by activating several layers of defence (Ton et al., 2009). When pathogens try to reach host cells they use physical and chemical weapons that either mimic or hijack plant cell hormonal imbalance or degrade the host cell structure (Robert-Seilaniantz et al., 2011). Plants, on the other hand, perceive microbial attack and prepare for an effective defence. After recognition, the first layers of defence are rapidly activated. This fast responses are triggered after PAMP recognition by surface receptors located at the cell membrane, but also by R-gene products that bind to avirulence factors activating gene-for-gene resistance (Jones and Dangl, 2006; Robert-Seilaniantz et al., 2011).

Cell wall-associated plant defence is important for basal resistance. During a fungal attack plant responds by strengthening its cell wall with a concomitant callose accumulation and $\mathrm{H}_{2} \mathrm{O}_{2}$ production as early events of a first defence layer. Callose is one of the main constituents of papillae, that contribute to avoid the entry of fungal pathogens (Flors et al., 2005; Mauch-Mani and Mauch, 2005; Ton et al., 2009; Vicedo et al., 2009). The role of $\mathrm{H}_{2} \mathrm{O}_{2}$ in defence is supported by many experimental reports, that show $\mathrm{H}_{2} \mathrm{O}_{2}$ is needed to avoid fungal penetration, and the enzymatic removal of this compound allow the entry of the fungus (Mellersh et al., 2002). On the other hand $\mathrm{H}_{2} \mathrm{O}_{2}$ can act as a signalling molecule due to its membrane permeability, interacting with intracellular events as well as intercellular cell-to-cell communications (Miller et al., 2009; Mittler et al., 2011).

The production and scavenging of reactive oxygen species (ROS) are intimately linked, and the balance between them will determine the defence signallingoutput as well as damage and cell-death responses. Plants have adapted to the toxic effects of massive ROS accumulation through a complex machinery that controls the redox state of the cell. Among this machinery, ascorbic acid (ASA) and glutathione (GSH) are the most important soluble antioxidant species maintaining reduced state in the cell. They are also connected through the Halliwell-Asada pathway that keeps ROS homeostasis under control (Foyer and Noctor, 2011). Both compounds have also a role in different physiological processes (Foyer and Noctor, 2011) and in plant defence (Barth et al., 2004; Dubreuil-Maurizi et al., 2011; Pastor et al., submitted). The role of these signals in plant defence has been established by studying mutants such as pad2 (phytoalexin deficient 2) which is impaired in GSH biosynthesis. It has disrupted the gene encoding $\gamma$-glutamylcysteine synthetase (GSH1), the first enzyme in the biosynthetic GSH pathway. This mutant is severely affected in resistance against $P$. syringae and $P$. brassicicola (Parisy et al., 2007). Other allelic mutants, like cad2-1 (cadmium-sensitive2-1), rml1 (root-meristemless1) and raxl-1 (regulator of APX2 1-1) show also low levels of GSH but the phenotypes among them are quite different, even when attacked by the same pathogen (Cobbet et al., 1998; Vernoux et al., 2000; Ball et al., 2004; Parisy et al., 2007). Contrastingly, the antioxidant-deficient mutant vtcl, is impaired in ASA biosynthesis by blocking the enzyme that catalyzes the step from D-Mannose-1-P to GDPD-Mannose in the Mannose/Galactose route, one of the pathways for ASA biosynthesis (Wheeler et al., 1998; Suza et al., 2010). This mutant displays higher levels of salicylic acid (SA), $\mathrm{H}_{2} \mathrm{O}_{2}$, abscisic acid (ABA) and NON-EXPRESSOR of PR-PROTEINS (NPR1), which all together confers enhanced resistance against P. syringae (Pastori et al., 2003; Barth et al., 2004; Colville and Smirnoff, 2008). The fact that the levels of SA are higher in $v t c 1$ (and also in $v t c 2$ ) than in wild type leads to a constitutive reduction of NPR1 through the activation of the thiorredoxin TRX-h5, needed for the nuclear allocation of this protein and subsequent PR-1 gene induction (Mou et al., 2003; Pavet et al., 2005; Tada et al., 2008). 
Interestingly, this resistant phenotype is not present in the case of necrotrophic fungus Plecthosphaerella cucumerina (P. cucumerina) infection (Pastor et al., submitted).

Plant resistance against pathogens with a necrotrophyc life style can variate depending on the pathogen strain and of course on the pathogen genus (Berrocal-Lobo et al., 2002; Hernandez-Blanco et al., 2009; Sanchez-Vallet et al., 2010). Although presumably $B$. cinerea and Alternaria brassicicola have similar life styles, the reactions triggered in a plant that has been attacked by any of them are distinct. Arabidopsis mutants impaired in ABAdependent signalling are more sensitive to Alternaria while the same mutants display enhanced resistance against Botrytis cinerea (Adie et al., 2007). It has been also demonstrated that despite $\mathrm{ABA}$ is a dispensable signal for basal resistance, it is an essential hormone to regulate primed callose depositions upon infection (Ton and Mauch-Mani 2004; Flors et al., 2008; Garcia-Andrade et al., 2011). Regarding to P. cucumerina, the role of ABA signalling pathway is a bit controversial since it is not essential for basal resistance, since $a b a l$ and abi4 show wild type resistance (Ton and Mauch-Mani, 2004), but on the other hand, aba2-1 displays enhanced susceptibility against the same strain of the pathogen (Garcia-Andrade et al., 2011). Another mechanism that has been clearly related to basal plant defence against $P$. cucumerina is the glutathion and the glucosinolate biosynthetic pathway. High levels of glutathione in the biosynthesis of Trp-derived metabolites are essential for Arabidopsis resistance against this necrotroph (Sanchez-Vallet et al., 2010). The resistance of some mutants such as pad2 and the double cyp79B2-cyp79B3 affected in different steps of this pathway is severely affected and accordingly, they present very reduced levels of camalexin, IA3 and RA, all them with antimicrobial properties (Sellam et al., 2007). The resistance of Arabidopsis to adapted strains of P. cucumerina have been described to involve in some aspects the signalling pathways of SA, ET, JA as well as the $\beta$ subunit of the heterotrimeric G-protein (AGB1) and the erecta receptor like kinase (ERRLK) (Berrocal-Lobo et al., 2002; Llorente et al., 2005). Most recent research in basal resistance against $P$. cucumerina points to three main relevant mechanisms such as ABAdependent signaling, cell wall modifications and ROS homeostasis (Ton and Mauch-Mani 2004; García-Andrade et al., 2011; Pastor et al., submitted). However the interplay of all these events and the coordination with the SA, JA and ET signalling pathways in the early or late events that take place during Arabidopsis-Plectosporium interactions remains largely unknown. In a search for ERECTA (ER)-receptor (RLKs) suppressors, Sanchez-Rodriguez et al (2009) demonstrated that ER regulates cell wall-mediated resistance in a different way to the developmental events linked to ER. It was found a positive correlation between uronic acid contents and Plectosporium resistance. In this line of evidence, callose-rich cell wall appositions also participate in the basal resistance to $P$. cucumerina since the callose impaired mutant pmr4.1 is more susceptible to the pathogen (Garcia-Andrade et al., 2011).

Despite the multilayer battery of defences, plants can further adapt their defence reactions by responding faster and stronger to pathogen or insect attack (Pastor et al., 2012). A well characterized priming mechanism is the enhancement of papillae few hours after the pathogen perception. We previously have demonstrated that primed callose deposition is a crucial mechanism for Arabidopsis primed responses against $P$. cucumerina (Pastor et al., submitted) and the induced resistance needs intact ABA signalling since mutation in ABI4-1 can block $\beta$-amino butyric acid (BABA)-induced callose (Ton et al., 2004, 2005). Luna et al (2011) demonstrated that ABA can exert a role as a suppressor or inductor of callose depending on a threshold of cellular $\mathrm{H}_{2} \mathrm{O}_{2}$ given by specific growth conditions and upon PAMP treatment. The signalling events upon PAMP perception that end up in the callose 
formation involves the mediation of the FLS2 receptor and downstream phosphorilation cacades mediated by MPK3 and MPK6, that activate an increase of ROS stimulated by the NADPH oxidase RbohD promoting the callose deposition and defence (Zhang et al., 2007). Seemingly, a cascade that involves ABA previous to the MPK6 activation and the ROS enhancement, regulates plant stress tolerance (Xing et al., 2008). A possible link between both signalling cascades is the OST1 kinase that regulates stomatal opening upon bacterial PAMP perception. This kinase stimulates downstream ABA, and increases ROS that precedes stomatal closure to avoid bacterial entrance into the leaf (Melotto et al., 2008; Ton et al., 2009). There are evidences of an upstream regulation of ABA on ROS homeostasis. In fact, Ghassemian et al (2008) sowed that exogenous treatments with ABA modify transcriptionally and probably post-transcriptionally the xantophyll cycle and the ASA recycling.

Although many reports connect ROS-dependent reactions and hormonal participation in the plant immune responses, it is not clear how relevant is the crosstalk between ROS and phytohormones for basal and primed defence against necrotrophs and in particular against Plectosporium. The NADPH oxidases and ROS homeostasis are part of the common signals induced together with SA, ET, JA and ABA signallingpathways along the plant responses to pathogens and abiotic stresses (Fujita et al., 2006; Mittler et al., 2011). In fact SA, ASA, GSH levels and $\mathrm{H}_{2} \mathrm{O}_{2}$ accumulation are tightly co-regulated events since mutants altered in SA, ASA and GSH display altered levels of $\mathrm{H}_{2} \mathrm{O}_{2}$ as well (Mou et al., 2003; Kerchev et al., 2011). The nitric oxide (NO) and GSH participate in the redox changes that induce the reduction of the NPR1 that probably precedes its entrance in the nucleus and the downstream activation of PR genes transcription (Mou et al., 2003; Spadaro et al., 2010). Recently it was demonstrated that constitutive priming exhibited by the ocp 3 mutant conjugates a fine tuning of ABA and JA as essential events for enhanced deposition at early time-points of callose against $B$. cinerea and P. cucumerina (García-Andrade et al., 2011). Noteworthy, the $O C P 3$ gene is a transcription factor that represses the cationic peroxidase Ep5C, subsequently the ocp 3 mutant displays elevated levels of $\mathrm{H}_{2} \mathrm{O}_{2}$ and the $\mathrm{H}_{2} \mathrm{O}_{2}$-inducible Ep5C and glutathione S-transferase1 marker genes (Cohego et al., 2005).

Regarding to primed defences, BABA-IR needs a fine tunning redox homeostasis which correlates with callose deposition, since mutants tested that are affected in ROS production or scavenging are also blocked in BABA-induced callose and $\mathrm{H}_{2} \mathrm{O}_{2}$ upon PAMP treatment and $P$. cucumerina infection. Mutants that were impaired in BABA-IR are also impaired in $\mathrm{H}_{2} \mathrm{O}_{2}$ production and callose deposition (Pastor et al., submitted). In the present manuscript we wanted to determine the interplay between ROS homeostasis during priming and the main hormonal pathways that regulate resistance to pathogens in Arabisopsis. We have studied the main marker genes of the SA, ABA and JA signalling pathways in the GSH mutant $p a d 2$ and in the ASA mutant $v t c 1$ during priming induced by BABA against the necrotroph $P$. cucumerina. We also have analyzed the hormonal interplay in this pathosystem. Complementary we have determined how mutations in the defence pathways controlled by hormones affect to the main hallmarks of ROS-mediated priming, which are the fast $\mathrm{H}_{2} \mathrm{O}_{2}$ accumulation followed by an enhanced callose accumulation. 
Results

Priming SA-mediated defences are dispensable to display intact BABA-IR.

The relevance of impairment of $\mathrm{H}_{2} \mathrm{O}_{2}$ in the hormonal responses to P. cucumerina, is investigated. We attempted to study the influence of GSHI and VTC1 in hormonal priming against this pathogen. For such purpose we used mutants affected in these genes, pad 2 and $v t c 1$, respectively. These genes are key elements in the Halliwell-Asada pathway, and alterations in one of both of them have a strong impact in plant responses to pathogens. Our experiments showed that BABA treatment stimulates priming of the SA marker gene PRI at 48 and $72 \mathrm{~h}$ post inoculation (Fig. 1). This correlates with a strong increase of SA and its main glucoside SAG at early time-points in BABA treated plants compared with their relative controls (Fig. 2). Therefore, the SA priming may suggest that this signalling pathway is a relevant event for BABA-IR against $P$. cucumerina, but it is clearly not the case since priming of $P R 1$ is lost in $v t c 1$ (intact in BABA-IR) and is intact at $48 \mathrm{hpi}$ in pad2 (hypersensitive to the pathogen and impaired in BABA-IR; Fig 1 and 2). Thus, when priming of $\mathrm{H}_{2} \mathrm{O}_{2}$ is blocked, the priming SA-dependent pathway seems not to be needed for priming defences.

These observations were showed previously by Ton and Mauch-Mani (2004) who demonstrated that $n p r l$ and $N a h G$ are intact in BABA-IR against this pathogen. These observations were also confirmed by the metabolome analysis that reveals among other conclusions, that the SA hormonal pathway was primed together with the phenylpropanoid biosynthesis (Fig S3). Therefore, the protection induced by BABA either in Col-0 or in the ASA mutant $v t c l$ cannot be explained on a SA-signalling basis despite its priming upon infection.

\section{ABA and JA-dependent pathways are boosted in $v t c 1$ and pad 2 upon infection}

Since SA seems not to be interconnected with ROS-mediated priming and cannot explain the different responses to BABA of $p a d 2$ and $v t c 1$, we further investigated the ABA and JA signalling pathways. ABA levels are induced at 48hpi in those genotypes that showed BABA-IR (Fig 1). In addition, the $M Y C 2$ gene, a positive regulator of JA-ABA crosstalk, is also primed by the treatment in Col-0 (Dombrecht et al., 2007; Pozo et al 2008; Fig 1). Interestingly, ABA levels were higher in the absence of infection in vtcl but they also remain at higher levels along the infection. The JA marker gene VSP2 is slightly activated by the infection in BABA-treated Col- 0 and vtcl, but it dramatically increased in pad 2 either in mock or in BABA treated plants (Fig 3). Noteworthy, the vtcl mutant which is protected by BABA shows priming of PDF1.2 while Col-0 plants did not. A strong increase of JA and its bioactive conjugate JA-Ile in the pad2 and vtcl was also observed upon infection (Fig 4). Again, it seems that BABA-IR is not correlated with the hormones and marker gene induction in the ROS mutants, as it happened with SA-dependent pathway. Taken together these results, it can be concluded that these mutants fail in some of the mechanisms of BABA-IR but in the case of $v t c 1$, it still can be further primed in downstream signallingcontributing to the resistance. For this reason we further investigated other defence layers that could be activated independently to ABA or JA and may explain a difference after BABA treatments in priming phenotypes of pad 2 and $v t c 1$. 


\section{Col-0}
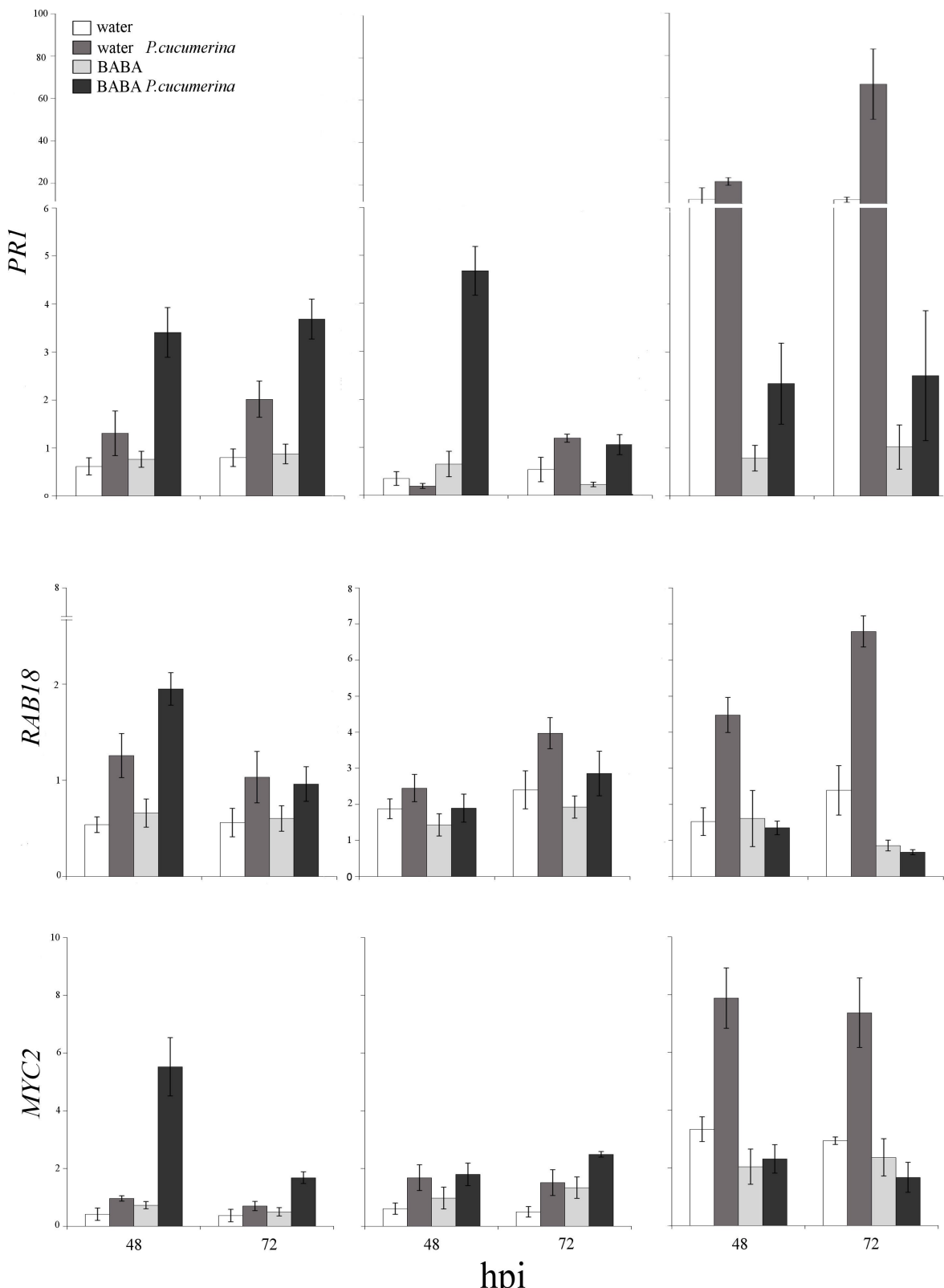

Figure 1: RT-qPCR analysis for $P R 1, R A B 18$ and $M Y C 2$ in water- and BABA- treated Col-0, pad 2 and $v t c 1$ plants. Fiveweek-old plants were soil drenched either with water or BABA, and 48h later, 6-8 leaves per plant were challenged by applying $6 \mu \mathrm{l}$ droplets containing $5 \times 10^{6}$ spores. $\mathrm{ml}^{-1}$ of P. cucumerina. Values represent fold induction respect to their controls at $\mathrm{t}=0$. Bars represent means $\pm \mathrm{SD}, \mathrm{n}=3$ independent replicates. 

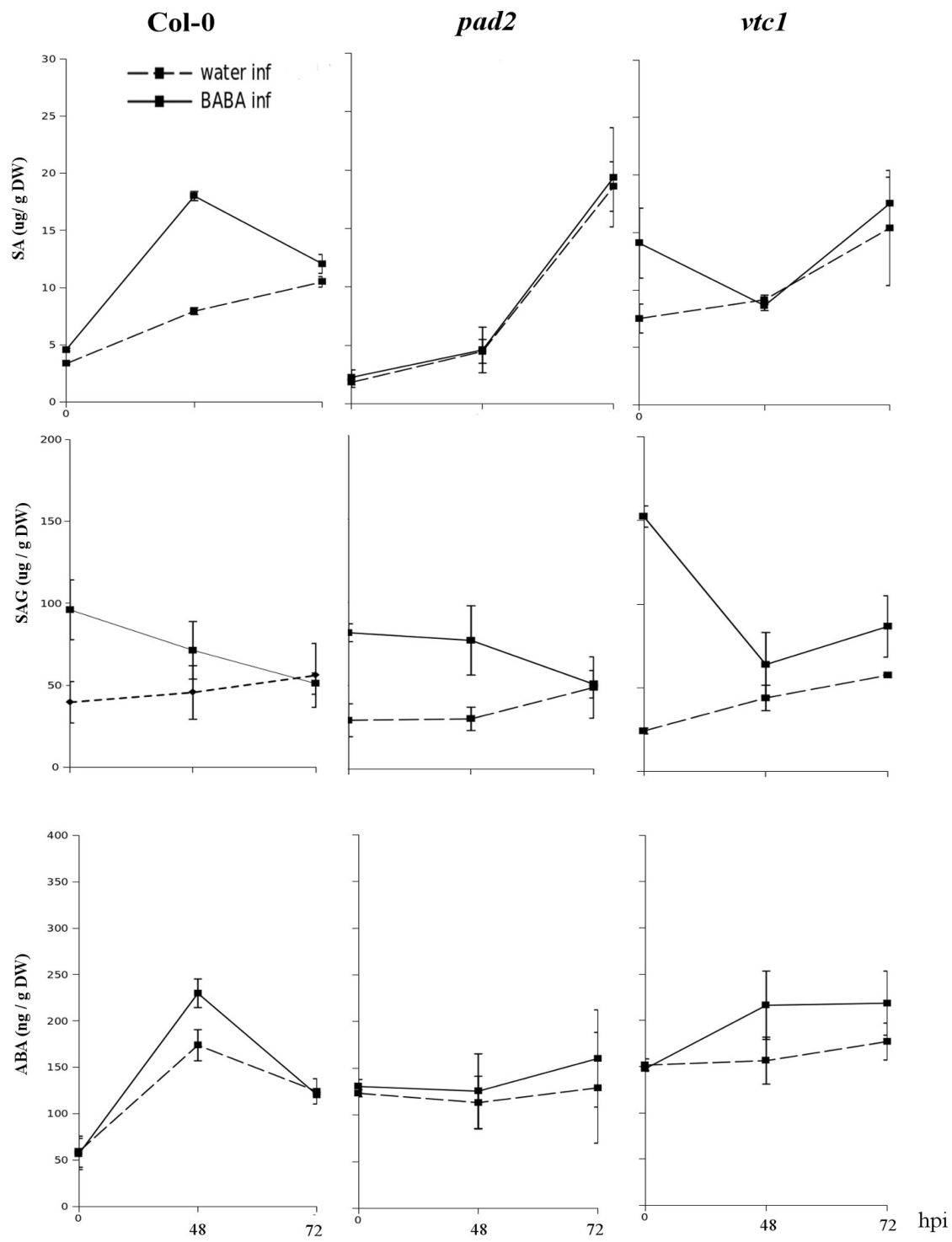

Figure 2: Effect of P. cucumerina inoculation on SA, SAG and ABA accumulation in water- and BABA- treated Col-0, pad2 and $v t c l$ plants. Five-week-old plants were soil drenched either with water o BABA, and 48h later, 6-8 leaves per plant were challenged by applying $6 \mu \mathrm{l}$ droplets containing $5 \times 10^{6}$ spores $\mathrm{ml}^{-1}$ of $P$. cucumerina. Infected leaves were collected at 48 and $72 \mathrm{hpi}$. Values are mean $\pm \mathrm{SD}, \mathrm{n}=3$ independent replicates.

\section{Secondary defence responses such as camalexin are primed in $v t c 1$}

It was demonstrated that BABA does not activate the production of the phytoalexin camalexin upon $P$. cucumerina infection. The main mechanism for BARA-IR in this pathosystem is based on ABA-mediated callose priming (Ton and Mauch-Mani, 2004). As a result of early defence activation, BABA-protected Col-0 plants do not activate later defences and in consequence camalexin production is down-regulated in BABA-treated plants (Ton and Mauch-Mani, 2004). In a search of a plausible explanation to the vtcl 


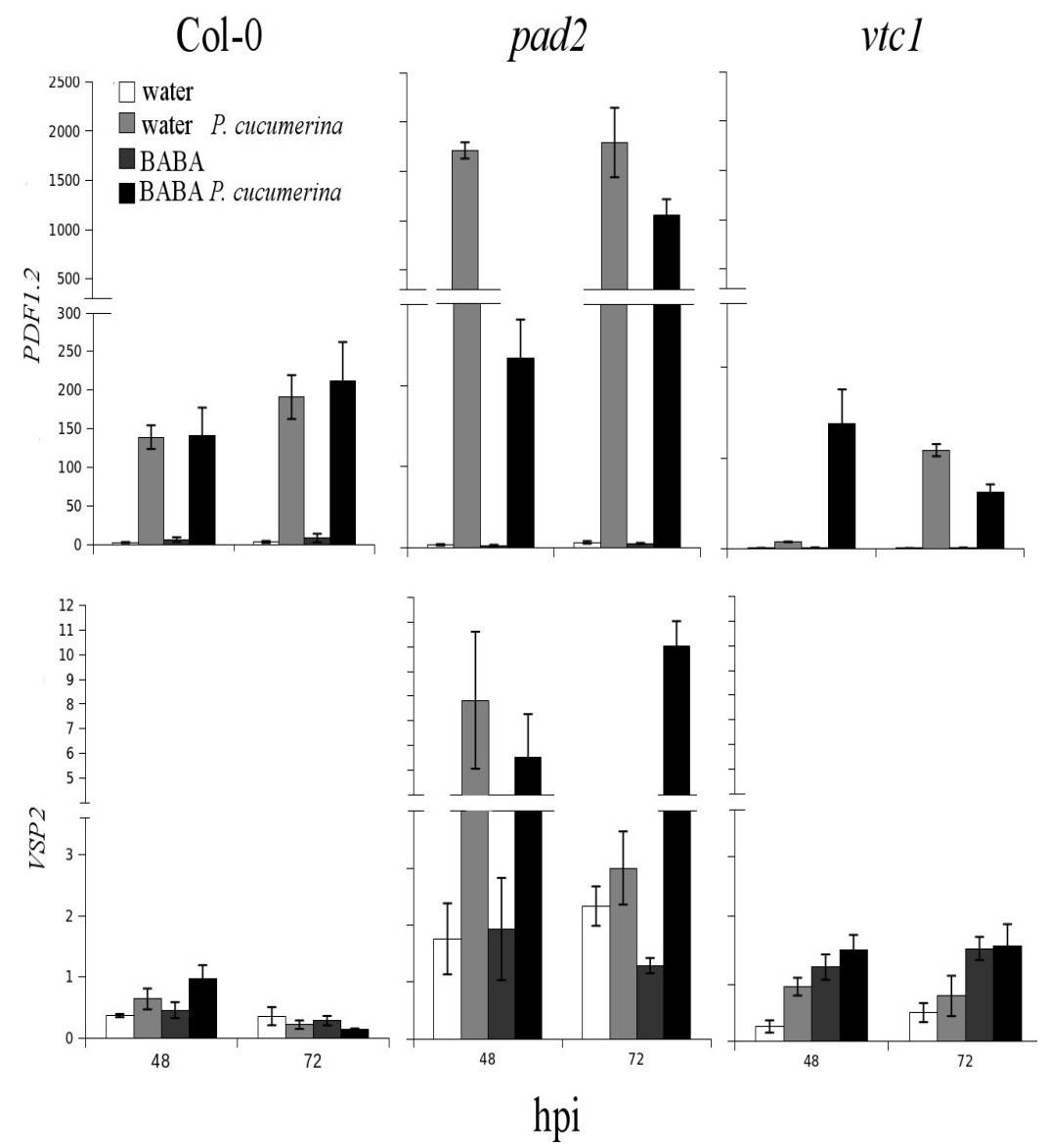

Figure 3: RT-qPCR analysis for $P D F 1.2$ and $V S P 2$ in water- and BABA- treated Col-0, pad 2 and $v t c 1$ plants. Five-week-old plants were soil drenched with water o BABA, and $48 \mathrm{~h}$ later 6-8 leves per plant were challenged by applying $6 \mu$ droplets containing $5 \times 10^{6}$ spores $\mathrm{ml}^{-1}$ of P. cucumerina. Values show fold induction respect their controls at initial conditions. Bars represent mean $\pm \mathrm{SD}, \mathrm{n}=3$ independent replicates.

protection by BABA we determined the levels of camalexin upon infection. As expected, it was found a decrease of camalexin production in infected treated Col-0 plants (Fig. 5).

Surprisingly, we observed a strong priming of camalexin in vtcl while pad2 plants fail to show this response. Obviously, this is a strong evidence demonstrating that BABA can further prime secondary layers of defence in case the first mechanisms triggered in wild type plants are dis-functional. Indeed, the differences in camalexin observed are a very likely mechanism to explain the different phenotypic responses of priming in pad2 and vtcl.

\section{ROS-mediated priming is de-regulated in $\mathrm{ABA}$ and $\mathrm{JA}$ mutants}

Since two mutants impaired in different aspects of the ROS homeostasis display different perception of BABA-IR and they seem to be interconnected to defence responses controlled by hormonal pathways and Trp derivatives, we wanted to check whether mutants in these pathways showed altered responses to the priming of callose and $\mathrm{H}_{2} \mathrm{O}_{2}$ induced by 

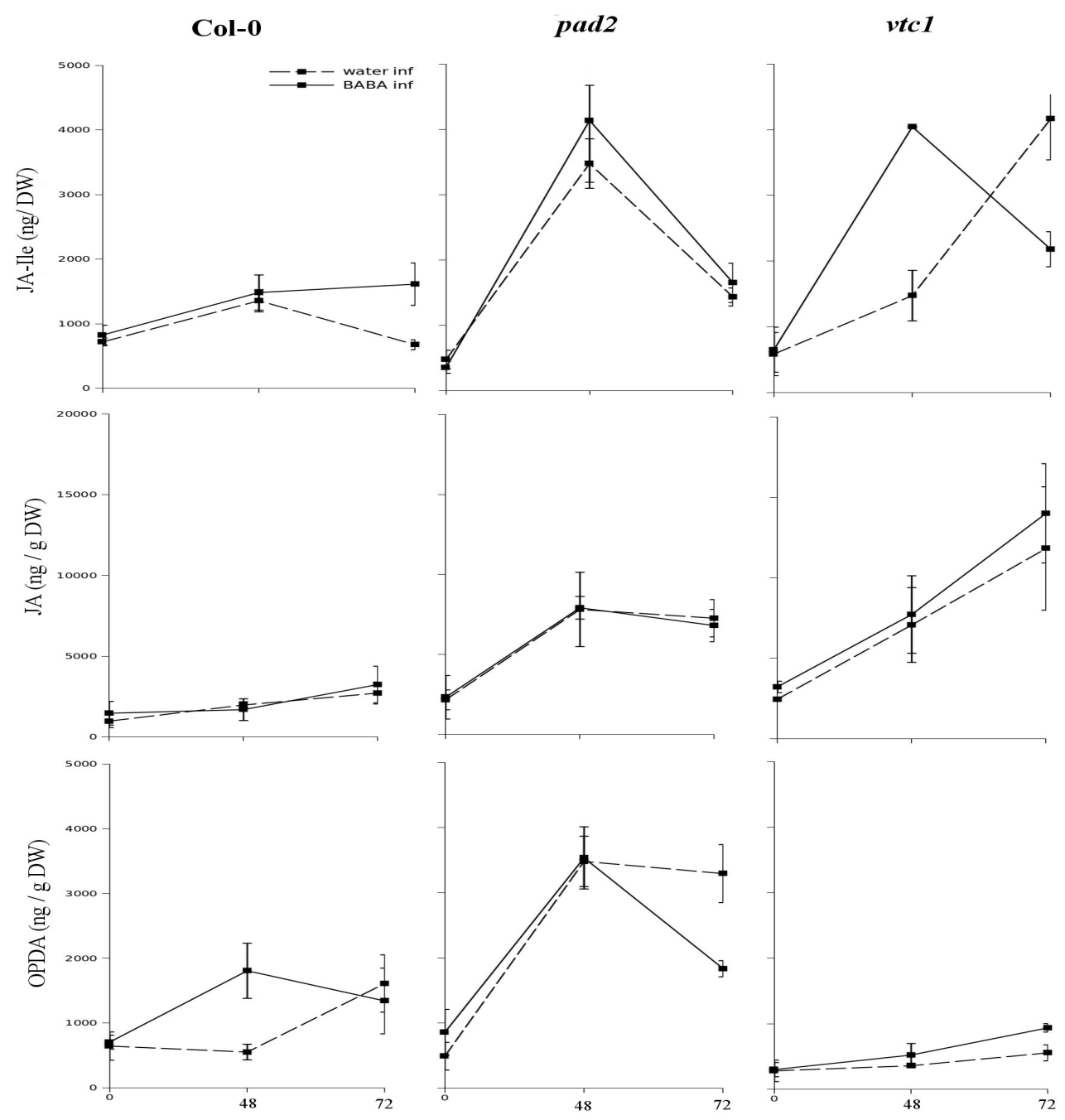

Figure 4: Effect of P. cucumerina inoculation on JA-Ile, JA and OPDA accumulation in water- and BABA- treated Col-0, pad 2 and $v t c l$ plants. Five-week-old plants were soil drenched either with water o BABA, and $48 \mathrm{~h}$ later, 6-8 leves per plant were challenged by applying $6 \mu \mathrm{l}$ droplets containing $5 \times 10^{6}$ spores $\mathrm{ml}^{-1}$ of $P$. cucumerina. Infected leaves were collected at 48 and 72 hpi. Values are mean $\pm \mathrm{SD}, \mathrm{n}=3$ independent replicates.

BABA upon P. cucumerina infection. The SA signalling mutant $n p r l$ showed wild-type responses to BABA-IR determined by the priming of callose and $\mathrm{H}_{2} \mathrm{O}_{2}$ (Fig. 6). On the other hand, the ABA mutants $n p q 2$ and aba2.3 were totally impaired in BABA-IR and accordingly showed no priming of ROS and callose upon infection. Interestingly, despite their low producction of callose they accumulate high levels of $\mathrm{H}_{2} \mathrm{O}_{2}$, this suggests that ABA participation in this interplay may happen between both events (Fig. 6). The last mutant tested, jin1 is altered in the $M Y C 2$ gene and it showed an intriguing phenotype. While it was intact in BABA-IR it did not showed callose priming and was hardly primed in $\mathrm{H}_{2} \mathrm{O}_{2}$ accumulation. This last result, confirms the relevance of the JA pathway in the mediation of ROS in BABA-induced priming. As it happened with $v t c 1$, there must be an additional layer of defence induced by BABA which is independent of callose priming. Attending to the priming of camalexin in $v t c l$ we investigated whether other Trp-triggered pathway were 


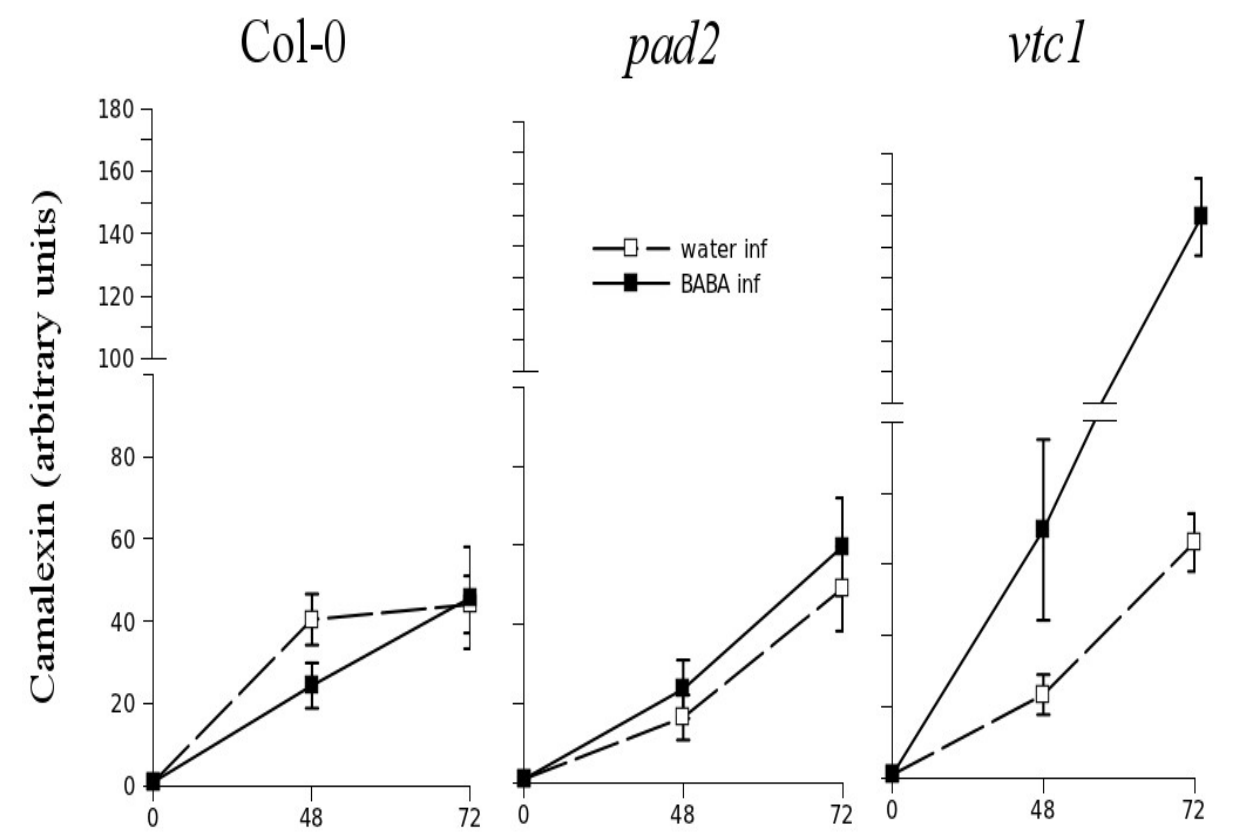

Figure 5: Relative levels of camalexin in Col-0, pad2 and $v t c 1$ plants. Treatments with water or BABA were performed $48 \mathrm{~h}$ before the inoculation with $5 \times 10^{6}$ spores/ $\mathrm{ml}$ of P. cucumerina. Plant tissue were collected as described in material and methods section, and camalexin levels were determined in freeze-dried material by HPLC-MS. Values are mean $\pm \mathrm{SD}, \mathrm{n}=3$ independent replicates.

relevant for BABA-IR mediated by $\mathrm{H}_{2} \mathrm{O}_{2}$ and callose against $P$. cucumerina. The result showed that pen2, blocked in the synthesis of indolic glucosinolates (Bednarek et al., 2009) was intact in BABA-IR and also in peroxide and callose priming.

\section{Metabolome analysis of BABA-IR against Plectosporium revealed contribution of Trp and Phenylpropanoid signaling pathways in the priming phenomenon}

In order to gain knowledge in a global vision of those metabolites participating in priming by BABA against $P$. cucumerina, we performed a metabolomic analysis by LC coupled to Q-TOF mass specrometry. A principal component analysis showed (PCA) obtained in positive and negative electro-spray ionization mode (ESI) using MarVis-filter software lead us to two main conclusions (Fig. 7). The first one is that groups of signals from uninfected plants either water or BABA treated overlap, this suggest that, despite some changes after BABA treatments are observed, the main components analyzed showed no changes induced in the absence of the challenge. The second main conclusion is that once the pathogen is present, the treated plants react differently and they cluster separately from water treated plants suggesting a different metabolomic profiling induced by BABA only in the presence of the pathogen, this data behavior is preticularly clear for negative ions while come data groups in positive fall outside this hypothesis. We focused our attention in the signals that showed significant differences between mock or BABA-treated plants upon infection. The metabolomic analysis using the MarVis-cluster software revealed three clear clusters of differentially accumulated signals (Fig. 8). In both ionization modes, it was found a group of metabolites which signals are enhanced in BABA-treated plants compared with 
A

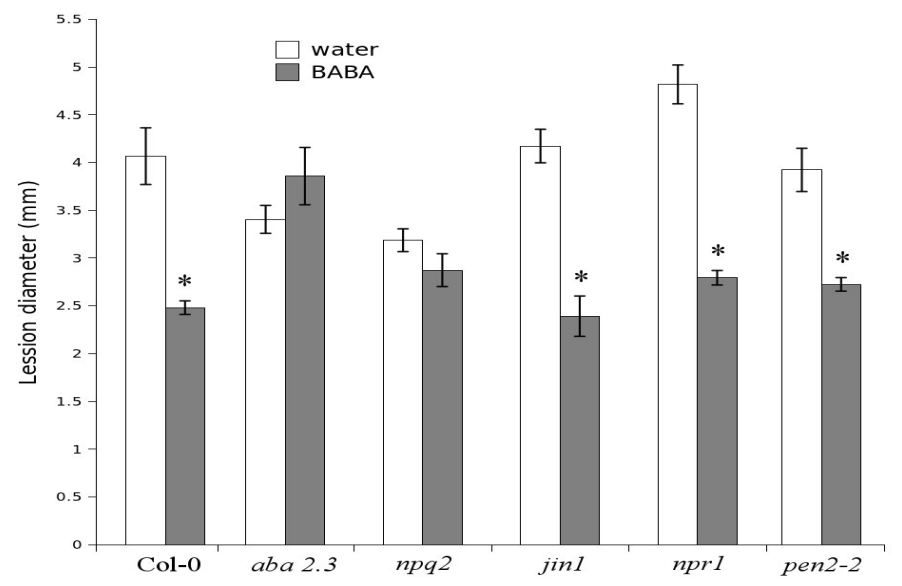

B
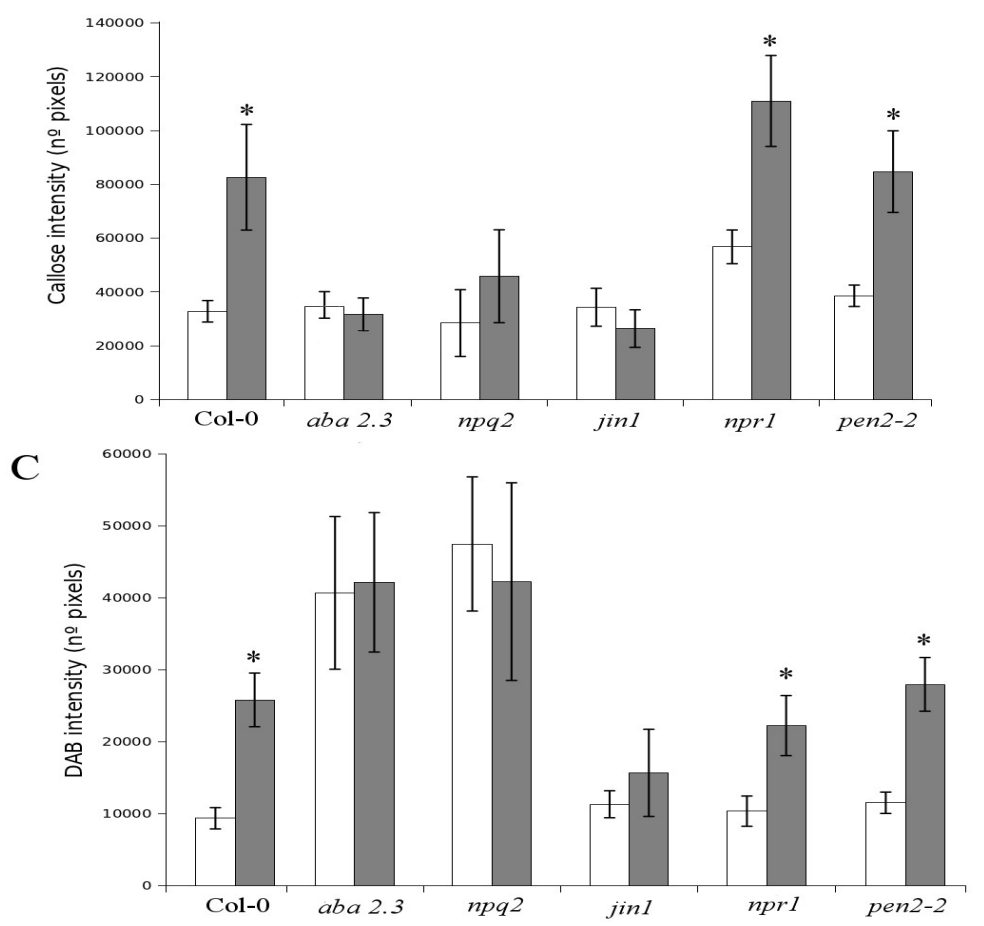

Figure 6: BABA-IR and priming of callose and ROS in mutants affected in the SA, ABA, JA and glucosinolate signallingpathways. A, Lesion diameter determined after 6 days post inoculation. Treatments with water or BABA were performed following the protocols described in the figure 1. Values are means $\pm S D(n=20)$. B Callose quantification from aniline blue stainings and $\mathrm{C} \mathrm{H}_{2} \mathrm{O}_{2}$ accumulation after 72 of infection in plants pretreated $48 \mathrm{~h}$ with water or BABA before infection. Values are mean $\pm \mathrm{SD}, \mathrm{n}=8$.

the controls upon infection. Within this cluster different groups of signals are observed, some of them are strongly primed and the signals are induced by BABA but at lower levels. There is also another group of metabolites that increased in the mock treated plants while they remain unchanged after BABA treatment. These signals are considered as antagonized by BABA since most of these changes are provoked by the pathogenic infection. Finally, there is a third group of analytes that reduce their concentration in BABA-treated plants and remain unchanged in water-treated plants. A pathway analysis performed using the clustered signals and subsequent search of these signals in Arabidopsis metabolomic databases such 
as Metlin and Aracyc showed that the Trp is the main pathway primed followed by the phenilalanine biosynthesis and the auxin-related signal transduction (Fig. S1, S2, S3; suplementary Tables 1,2 and 3). The identity of some of the primed signals such as tyramine and IAA was confirmed by a search of the spectrum after a T-wave fragmentation of the corresponding peaks of the chromatogram (Fig. S4).
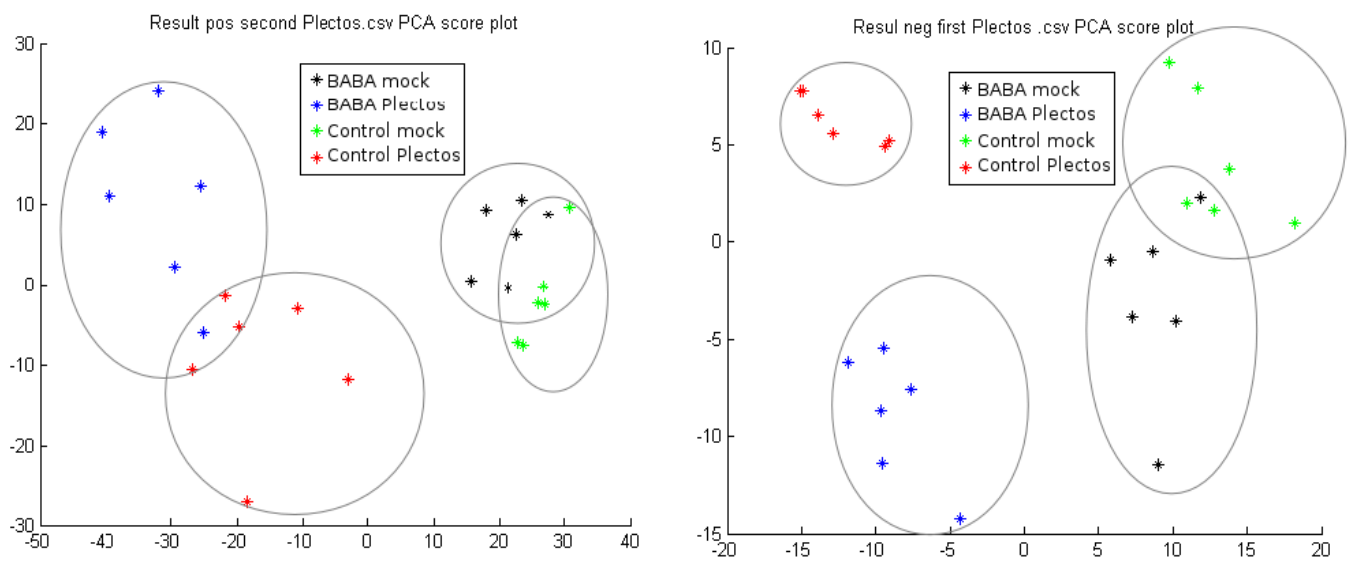

Figure 7: Principal Component Analysis of signals obtained in positive and negative ESI mode. Marvis software for metabolomic analisys was used to generate the PCA plot from to specifically identify $\mathrm{m} / \mathrm{z}$ changes after infection and BABA treatment in Col-0. PCA plots were constructed for P. cucumerina infected wild type (control) plants in water and BABA treatments, as well as non infected plants water or BABA treated.

ESI-
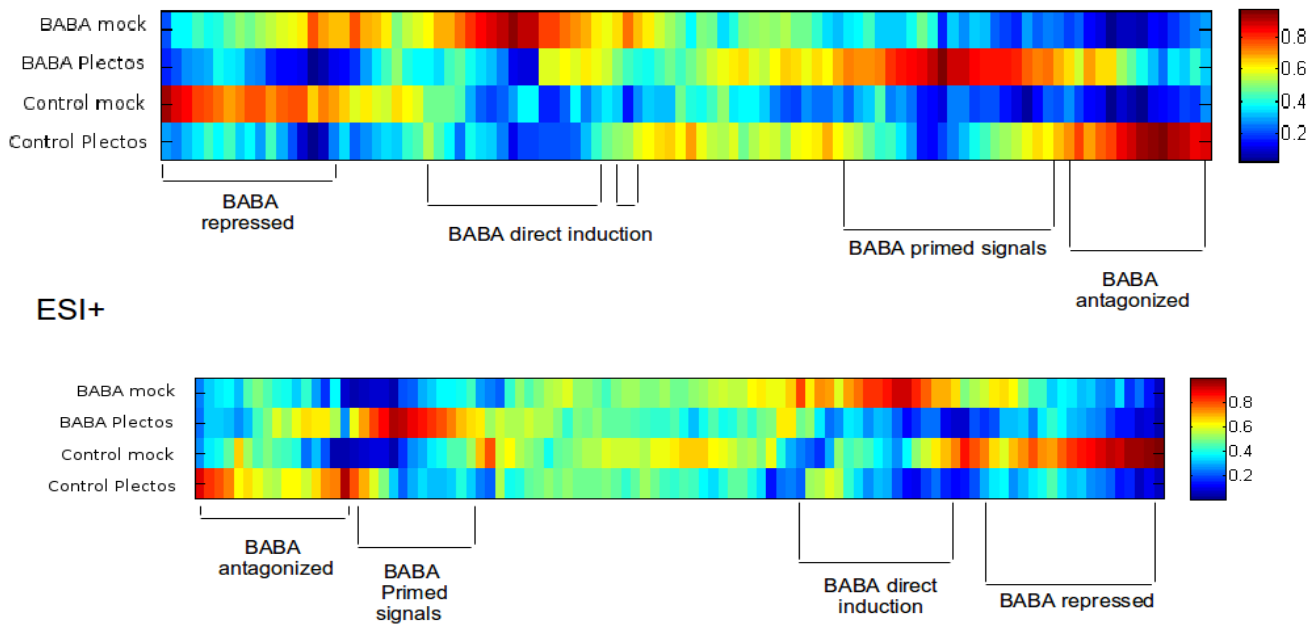

Figure 8: Clustering analysis of signals obtained by LC-Q-TOF analysis in positive and negative electro-spray ionization mode of Col-0 (control) plants treated either with water or BABA, infected or not with $P$. cucumerina. Five-week-old plants were pretreated with BABA $48 \mathrm{~h}$ before inoculation. Samples were collected at $48 \mathrm{hpi}$. Heat-maps were generated by using MarVis-Filter and Cluster software for metabolomics after Kluscal-Wallis test. Data are represented in a $\log _{2}$ scale. Only significant signals with a $\mathrm{p}$ value $<0.05$ are shown. 


\section{Discussion}

Although P. cucumerina is considered a fungus with a necrotrophyc life style, the basal resistance mechanisms activated against adapted strains of this ascomycete involve signallingpathways dependent on SA, JA, ABA and ET (Berrocal-Lobo et al., 2002) as well as tryptophan-derivative metabolites (Sánchez-Vallet et al., 2010). On the other hand, the potentiated mechanisms of resistance against this pathogen do not overlap with basal resistance (Ton et al., 2004; Pastor et al., 2012). Priming induced by BABA against $P$. cucumerina requires a precise equilibrium of $\mathrm{H}_{2} \mathrm{O}_{2}$ and callose and this equilibrium is also regulated by $\mathrm{ABA}$-dependent signaling. In fact, BABA-IR is not functional in mutants affected in ABA signaling, such as abal and abi4, but also in mutants impaired in callose synthesis (pmr4; blocked in GSL5) and genes involved in ROS homeostasis, such as RBOHD and PAD2 (Ton and Mauch-Mani 2004; Pastor et al., submitted). Interestingly, in the present research we found that the SA defence signalling pathway is still primed in Col0 treated by BABA. On the other hand non of JA pathway markers or the hormone JA-Ile are primed, with the exception of an enhancement of OPDA observed 48hpi in treated Col-0 plants. This oxylipin was reported to display roles in defence independently to JA- or JAIle- regulated responses. OPDA can be stored as arabidopsides after pathogen attack or wounding, it also has antimicrobial effect and mediates induced resistance against necrothophs (Prost et al., 2005; Kourtchenko et al., 2007; Vicedo et al., 2009). We also have observed that the Trp derived branch of indolic glucosinolates regulated by PEN2 was also not involved in priming by BABA, and the phytoalexin camalexin was down-regulated in Col-0-primed plants.

Contrastingly, metabolomic experiments showed an enhanced activation of Trp derived metabolites and also an accumulation of signals in the Phenylpropanoid, SA and IAA pathways. These observations let us to hypothesize that priming induced by BABA is an non-unique horizontal phenomenon. This suggests that priming may involve two different mechanisms to protect the plant. The first would comprise a group of essential genes and metabolites that abolish priming when are not available or functional. The second, would consist of a group of dispensable signals, that in a lower extent may help the plant to defend against the pathogen. This dispensable signals are perhaps a consequence of the remaining events triggered during basal defence of the plant that of course is still functional. A surprising phenotype was observed in jinl. This mutant is protected by BABA but fails in priming of callose and $\mathrm{H}_{2} \mathrm{O}_{2}$ and shows wild type levels of both, indicating that this two events seem to be connected to JA signallingbut other layers of protection should be still primed in jin1. The interplay between ABA, callose and JA was described by GarcíaAndrade et al (2011).

The priming mutant ocp 3 is protected by BABA but in addition it displays enhanced defence responses in the absence of treatment. Consequently, $O C P 3$ acts as a suppressor of primed responses and the enhanced callose deposition in ocp 3 requires intact JA and ABA signalling. Accordingly to the suggested interplay, ocp3 displays elevated levels of $\mathrm{H}_{2} \mathrm{O}_{2}$ (Cohego et al., 2005). Our results, however, show that JA signalling is not participating in BABA-IR despite its connection with peroxide and callose priming, therefore priming phenomenon can be regulated through different mechanisms depending on the chemical treatment or its constitutive expression in priming mutants. The intact BABA-IR in jin 1 also suggests that $\mathrm{BABA}$ can stimulate subsequent layers of defence in mutants that are impaired in dispensable signals. 
GSH and ASA are the major non enzymatic antioxidants, they scavenge ROS mainly through the Halliwell-Asada pathway. The location of these antioxidants in all parts of the cell, including the apoplast, highlight the relevance of these compounds for the physiological processes of the plant. In Arabidopsis, it was described that reduced levels of

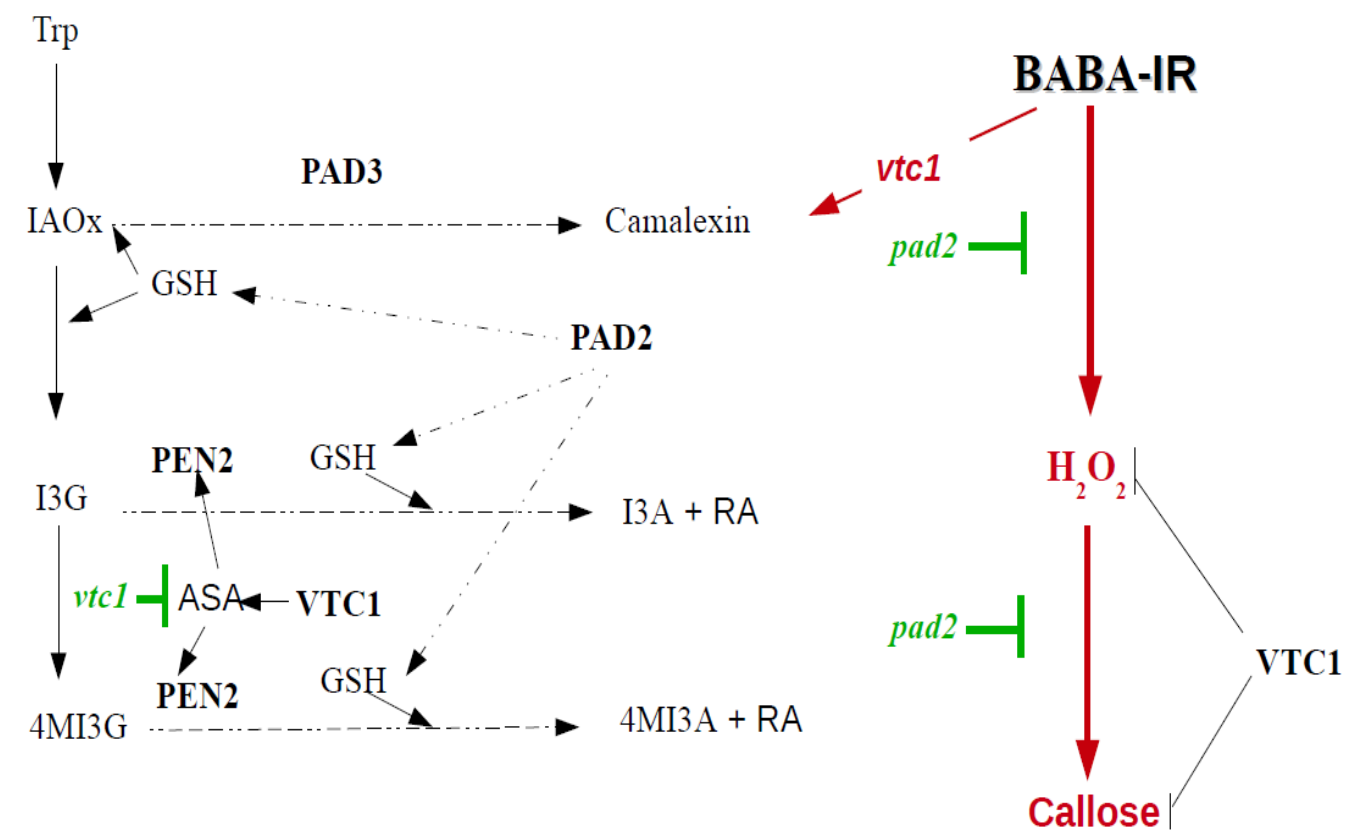

Figure 7: Participation of VTC1 and PAD2 (GSH1) in the $\mathrm{H}_{2} \mathrm{O}_{2}$, callose and indol glucosinolates interplay in priming. BABA-induced resistance against $P$. cucumerina is mediated by priming of callose and $\mathrm{H}_{2} \mathrm{O}_{2}$. A threshold of these early defences is needed to display intact priming. A tight regulation through the antioxidant system allow to keep the increases of ROS under elevated but non-toxic levels. PAD2 is a necessary signal mediating BABA-IR as well as $\mathrm{H}_{2} \mathrm{O}_{2}$ and callose priming upon $P$. cucumerina infection. On the other hand, VTC1 is also a signal required for callose and $\mathrm{H}_{2} \mathrm{O}_{2}$ priming but not for enhanced protection. In addition, VTC1 acts as a repressor of callose and $\mathrm{H}_{2} \mathrm{O}_{2}$ that are over accumulated when this gene is blocked (vtc1). When VTC1-dependent signallingis de-regulated in $v t c 1$, other layers of defence that involve Trp derivatives can still be primed. Both, ASA and GSH participate in the glucosinolate pathway. The amino acid Triptophan (Trp) after different enzymatic reactions generates other indol glucosinolates (IGS) and camalexin. These reactions need GSH as a sulfur donor, and ASA as a cofactor of the myrosinase PEN2 in the (IGS) breakdown products (I3A and 4MI3A). Upon $P$. cucumerina challenge, low levels of ASA may reduce the PEN2 functionality and therefore redistribute the pathway to the camalexin synthesis. Upon priming, since the early events such as callose and $\mathrm{H}_{2} \mathrm{O}_{2}$ are not responding, the $P E N 3$-regulated branch can be further stimulated in $v t c 1$, that displays intact BABA-induced protection and camalexin priming. Red colors show up-regulated events and green color presents down-regulated processes. Black color presents wild type responses. IAOx: indol-3-acetaldoxime; I3G: indol-3-ylmethylglucosinolate; 4MI3G: 4-methoxyindol-3-ylmethylglucosinolate; I3A: indol-3ylmethylamine; 4MI3A: 4-methoxyindol-3-ylmethylamine; RA: Raphanusamic.

antioxidants have consequences in the JA and SA signalling(Brosché and Kangasjärvi, 2012). Our results have shown that a modification in the redox equilibrium in mutants with altered production of antioxidants, changes radically the profile of hormonal-dependent primed responses. High basal levels in SA content and the PRI expression without infection in $v t c l$ has been postulated as a reason for the resistance of this mutant to Pseudomonas syringae (Mukherjee et al., 2010). Contrastingly, vtcl does not exhibit enhanced resistance against $P$. cucumerina. The vtcl mutant displays constitutive elevated levels of callose and $\mathrm{H}_{2} \mathrm{O}_{2}$ upon chitosan treatment and $P$. cucumerina infection. Noteworthy, this enhanced response does not explain the BABA-IR in $v t c l$ since the levels of callose and peroxide are not primed. Thus, VTCl is a key element needed to express $\mathrm{H}_{2} \mathrm{O}_{2}$ and callose priming but 
the multilayer priming of defence induced by BABA should be still active and subsequently, the mutant is protected by BABA. Comparatively, impairment in GSHI blocks both basal and induced resistance. The genetic and hormonal profiling performed in vtcl and pad2treated plants upon challenge discards ABA, JA and SA priming as necessary mechanisms for BABA-IR in $v t c 1$. Consequently, the BABA protection in $v t c l$ could not be explained by a classical priming of hormone-controlled signaling. The BABA-IR impaired mutant pad 2 shows priming of $P R 1$, but this stronger response is not found in $R A B 18$ and $M Y C 2$. Surprisingly, the abolishment of GSH1 activates a high induction of JA responsive genes and oxylipins after the infection, probably due to the elevated disease pressure in this hypersensitive mutant. Additionally, the priming of the hormones SA, ABA and OPDA observed in Col-0 is equally lost in $v t c 1$ and pad2. One of the last attempts to explain the intact IR in $v t c 1$ was performed by studying the phytoalexin production triggered by the infection in water or BABA treated plants. As observed in figure 5, either Col-0 or pad2 are not primed in camalexin, but the phytoalexin is strongly induced by BABA in infected $v t c 1$. Intriguingly, either camalexin or indolic glucosinolates were not needed for priming in wild type plants, but the observation of camalexin priming in $v t c 1$ suggests that the expected down-regulation of PEN2 by the absence of ASA (Burmeister et al., 2000) reorganized the Trp derived metabolism into camalexin rather than other indolic glucosinotales (Fig. 7). This would explain why vtcl still displays induced resistance due to camalexin priming while pad2 is totally impaired in both events. Thus, BABA also protects stressed plants when the firsts layers of defence are altered. Obviously, this is not extensive for essential priming events but it seems very likely that BABA can further prime defence when additional dispensable defence signalling is not functional. These observations confirm hypothesis of the plant conditioning or priming as a horizontal and multilayer defence phenomenon.

\section{Material and Methods}

\section{Plant material, growth conditions and chemical treatment}

Col-0 and mutants, were sown in jiffy-7 peat pellets (Clause-Tezier Ibérica, http://www.clausetezier.com/). Plants were grown in a growth phytochamber with 100-150 $\mu \mathrm{M} \mathrm{m}^{-2} \mathrm{sec}^{-1}$ at $21^{\circ} \mathrm{C}$ and $19^{\circ} \mathrm{C}$ under $9 \mathrm{~h}$ light/dark cycles and $65 \%$ humidity. Five-week-old plants were soil-drenched with $150 \mu \mathrm{M}$ of BABA $48 \mathrm{~h}$ before inoculation.

\section{Plectosphaerella cucumerina bioassays}

P. cucumerina infections were performed in 5-week-old-plants pretreated with 150 $\mu \mathrm{M}$ BABA, by a $6 \mu \mathrm{l}$ of a suspension of fungal spores of $5 \times 10^{6}$ spores $\mathrm{ml}^{-1}$ in fully expanded leaves. Then, plants were maintained at $100 \%$ of relative humidity. Disease symptoms were evaluated by determining the average lesion diameter in 20-30 plants per treatment. Callose accumulation was determined in infected leaves at different time points after inoculation, using aniline blue staining and subsequent analysis by epifluorescence microscopy. Staining and quantification were performed as described in Ton and MauchMani (2004). For DAB staining, infected leaves were cut and put immediately in $1 \mathrm{mg} / \mathrm{ml}$ of $\mathrm{DAB}$, subsequently, leaves were destained in $96 \%$ ethanol and rehydrated in glicerol $60 \%$. $\mathrm{H}_{2} \mathrm{O}_{2}$ was visualized under bright field microscopy. Quantification was performed as described in Luna et al (2011). 


\section{Determination of hormonal levels}

Levels of ABA, JA, JA-Ile, OPDA, camalexin, were performed as described in Kravchuck et al (2011) and, Pastor et al (2012) for SAG and SA determination. Briefly, fresh material was frozen dried in liquid nitrogen. Before extraction, a mixture of internal standards was added as a $100 \mathrm{ng} \mathrm{ml}^{-1}\left({ }^{2} \mathrm{H}_{6}-\mathrm{ABA}\right.$, dhJA, $\left.{ }^{2} \mathrm{H}_{5}-\mathrm{SA}\right)$. Dry tissue $(0.03 \mathrm{~g})$ was homogenized in $2.5 \mathrm{ml}$ of ultrapure water. After centrifugation (4000xg 40'), the supernatant was recovered and adjusted to $\mathrm{pH} 2.7$ with $6 \%$ of acetic acid. Subsequently partionated twice against an equal volume of diethyl ether. After discarding the aqueous phase, the organic fraction was evaporated in a speed-vacuum at room temperature, and the solid residue was resuspended in $1 \mathrm{ml}$ of a water /methanol (90:10) solution. This final volume was filtered through a $0.22 \mu \mathrm{m}$ cellulose acetate filter. A $20 \mu \mathrm{l}$ aliquot of this solution was then directly injected into the HPLC system. Analyses were carried out using a Waters (Milford) Alliance 2690 HPLC System with a nucleosil ODS reversed-phase column (100 $\mathrm{mm} \times 2 \mathrm{~mm}$ I.d.; $5 \mu \mathrm{m})$. The chromatographic system was interfaced to a Quatro LC (quadropole-hexapole-quadrupole) mass spectrometer (Micromass). Masslynx NT (Micromass) software version 4.1 was used to process the quantitative data from both the calibrations standards and the plant samples. All the hormones were quantified by using the calibration curves of standards SA, SAG, ABA, JA and OPDA (Sigma, Barcelona, Spain).

\section{RNA isolation and RT-qPCR analysis}

RNA was extracted from leaf tissue using E.Z.N.A. ${ }^{\text {TM }}$ Plant RNA Kit OMEGA biotek (www.omegabiotek.com). Arabidopsis leaf tissues samples for RNA isolation were collected at 0, 48 and 72 hours after inoculation. Leaf tissue from eight plants were collected. For quantitative real-time $1.5 \mu \mathrm{g}$ of total RNA was digested using 1 unit of RQ1 Rnase-Free Dnase buffer and up to $10 \mu \mathrm{l}$ of Mili-Q water, and incubated for $30 \mathrm{~min}$ at $37^{\circ} \mathrm{C}$. After incubation, $1 \mu$ of RQ1 Dnase stop buffer was added, and the solution was incubated again at $65^{\circ} \mathrm{C}$ for $10 \mathrm{~min}$ to inactivate the Dnase. Highly pure RNA was used for the RT reaction. The RT reaction was performed by adding $2 \mu \mathrm{l}$ of RT buffer, $2 \mu \mathrm{l}$ of $5 \mathrm{mM}$ dNTP, 2 $\mu \mathrm{l}$ of $10 \mu \mathrm{M}$ Oligo (dT) 15 primer (Promega), $1 \mu \mathrm{l}$ of U $\mu \mathrm{l}-1$ Rnasin inhibitor (Promega) and $1 \mu \mathrm{l}$ of Omniscript reverse transcriptase (Quiagen, http://www.qiagen.com). The reaction mixture was incubated at $37^{\circ} \mathrm{C}$ for $60^{\circ} \mathrm{C}$. Less than $10 \%$ of the volume of the RT reaction was used for the quantitative PCR. A melting curve analysis was performed at the end of PCR reaction to confirm the product purity. The list of primers are in supplemental material (Table S5). Values are normalized with GAPDH3 expression in the same sample, using the $2^{\Delta \mathrm{Ct}}$ method, where $\Delta \mathrm{Ct}=\mathrm{Ct}($ reference gene $)-\mathrm{Ct}$ (gene of interest). Fold induction values of gene expression were normalized to values relative to Col-0 water or Col-0 BABA at $0 \mathrm{~h}$ before infection. The experiments were repeated with a second housekeeping gene Atlg13320 with similar results.

\section{Metabolomic analysis}

Freeze dried plant material was extracted with water: methanol $\left(\mathrm{H}_{2} \mathrm{O}: \mathrm{MeOH} ; 90: 10\right)$ containing $0.01 \%$ of $\mathrm{HCOOH}$. Leaf extracts were centrifuged $10 \mathrm{~min}$ at $15000 \mathrm{rpm}$. Supernatant was purified through $0.22 \mathrm{um}$ cellulose filter. Aliquots of $20 \mathrm{uL}$ were injected 
onto a UPLC (Agilent, Acquity) coupled to a quadrupol-time of flight mass spectrometer (QTOF Premier) through an electrospray ionization source. The LC was developed for 25 min in a common $\mathrm{C} 18$ column using a standard variable $\mathrm{H}_{2} \mathrm{O}: \mathrm{MeOH}$ gradient. Mass detection was performed using a $25 \mathrm{~V}$ of cone energy. TOF detector was programmed with two functions, F1 for non fragmented ions and F2 for detection of ions after a T-wave fragmentation using a gradient of collision energy from 15 up to $40 \mathrm{eV}$. The mass range detected was fixed between $100-1000 \mathrm{~m} / \mathrm{z}$. Signal collection was performed using the Masslynx 4.1 software.

After transformation of raw data into cdf format, the signals were processed using the Rkward for statistical computing from the Bioconductor web site (www.bioconductor.org) The peaks were identified and grouped using the XCMS library and the MatchedFilter algorithm (Smith et al 2006). Selected signals were visualized and clustered using the Mar-Vis Filter and MarVis Cluster software (Saeed et al 2003). The multivariate analyses applied include hierarchical cluster analysis (HCA) Heatmaps were generated after a t-test by applying a standard Kluskal-wallis correction and a hierarchical clustering. Those signals following the selected criteria were matched in Metlin, Massbank and AraCyc databases. A confirmation of the identity of several representative compounds was performed by exact mass identification in F1 and fragmentation spectrum identification in the F2.

\section{References}

Adie B. A., Perez-Perez M. M., Godoy M., Sánchez-Serrano J. J., Schmelz E. A., Solano R., 2007. The Plant Cell 19, 1665-1681.

Ball L., Acotto G. P., Bechtold U., Creissen G., Funk D., Jimenez A., Kular B., Leyland N., Mejia-Carranza J., Reynolds H. et al 2004. Evidence for a direct link between glutathione biosynthesis and stress defence gene expression in Arabidopsis. Plant Cell 16, 2448-2462.

Barth C., Moeder W., Klessig D.F., Conklin P.L., (2004). The timing of senescence and response to pathogens is altered in the ascorbate-deficient arabidopsis mutant vitamin c-1. Plant Phys 134, 1784-1792.

Berrocal-Lobo M., Molina A., Solano R., 2002. Constitutive expression of ETHYLENERESPONSE-FACTOR1 in Arabidopsis confers resistance to several necrotrophic fungi. Plant Journal 29, 23-32.

Brosché M., Jangasjärvi J., 2012. Low antioxidant concentrations impact on multiple signalling pathways in Arabidopsis thaliana partly through NPR1. J. Experimental Botany 63, 1849-1861.

Burmeister W. P., Cottaz S., Rollin P., Vasella A., Henrissat B., 2000. High resolution X-ray crystallography shows that ascorbate is a cofactor for myrosinase and substitutes for the function of the catalytic base. J. Biol. Chem 275, 39385-39393.

Cobbett C. S., May M. J., Howden R., Rolls B., 1998. The glutathione-deficient , cadmiumsensitive mutant, cad2-1, of Arabidopsis thaliana is deficient in $\gamma$-glutamylcysteine synthetase. Plant J. 16, 73-78.

Coego A., Ramírez V., Ellul P., Mayda E., Vera P.. 2005. The $\mathrm{H}_{2} \mathrm{O}_{2}$-regulated Ep5C gene encodes a peroxidase required for bacterial speck susceptibility in tomato. Plant 
Journal 42, 283-293.

Colville L., Smirnoff N., 2008: Antioxidant status, peroxidase activity and PR protein transcript levels in ascorbate-deficient Arabidopsis thaliana vtc mutants. 59, 38573868.

Dombrecht B., Xue G. P., Sprague S. J., Kirkegaard J. A., Ross J. J., Reid J. B., Fitt G. P., Sewelam N., Schenk P. M., Manners J. M., Kazan K., 2007. MYC2 differentially modulates diverse jasmonate-dependent functions in Arabidopsis. Plant Cell 19, 2225-2245.

Dubreuil-Maurizi C., Vitecek J., Marty L., Branciard L., Frettinger P., Wendehenne D., Meyer A. J., Mauch F., Poinssot B., 2011. Glutathione deficiency of the Arabidopsis mutants pad2-1 affects oxidative stress-related events, defence gene expression, and the hypersensityve response. Plant Physiol 157, 2000-2012.

Ferrari S., Plotnikova J. M., De Lorenzo G., Ausubel F. M., 2003. Arabidopsis local resistance to Botrytis cinerea involves salicylic acid and camalexin and requires EDS4 and PAD2, but not SID2, EDS5 or PAD4. Plant Journal 35, 193-205.

Flors V., Ton J., van Doorn R., Jakab G., García-Agustín P., Mauch-Mani B., 2008. Interplay between $\mathrm{JA}, \mathrm{SA}$, and $\mathrm{ABA}$ signalling during basal and induced resistance against Pseudomonas syringae and Alternaria brassicicola.. Plant Journal 54: 8192.

Flors, V., Ton, J., Jakab, G., Mauch-Mani, B., 2005. Abscisic acid and callose: Team players in defence against pathogens? J. Phytopathol. 153, 377-383.

Foyer C. H., Noctor G., 2011. Ascorbate and glutathione: the heart of the redox hub. Plant Physiology 155, 2-18.

Fujita, M., Fujita, Y., Noutoshi, Y., Takahashi, F., Narusaka, Y., Yamaguchi-Shinozaki, K., Shinozaki, K., 2006. Crosstalk between abiotic and biotic stress responses: a current view from the points of convergence in stress signalling networks. Cur. Opin. Plant Biol. 9: 436-442.

García-Andrade J., Ramírez V., Flors V., Vera P., 2012. Arabidopsis ocp3 mutant reveals a mechanism linking $\mathrm{ABA}$ and JA to pathogen-induced callose deposition.Plant Journal 67, 783-794.

Ghassemian M., Lutes J., Chang H.S., Lange I., Chen W., Zhu T., Wang X., Lange B. M., 2008. Abscisic acid-induced modulation of metabolic and redox controlpathways in Arabidopsis thaliana. Phytochemistry 69, 2899-2911.

Jones J.D.G., Dangl J.L., 2006. The plant immune system. Nature 444, 323-329.

Kravchuk Z., Vicedo B., Flors V., Camañes G., González-Bosch C., García-Agustín P., 2011: Priming for JA-dependent defenses using hexanoic acid is an effective mechanism to protect Arabidopsis thaliana against B. cinerea. Journal of Plant Physiology 168, 359-366.

Kourtchenko O., Andersson M. X., Hamberg M., Brunnström A., Göbel C., McPhail K. L., Gerwick W. H., Feussner I., Ellerström M., 2007. Oxo-Phytodienoic acid-containing galactolipids in Arabidopsis: jasmonate signallingdependence. Plant Physiology $145,1658-1669$.

Llorente F., Alonso-Blanco C., Sánchez-Rodriguez C, Jorda L., Molina A., 2005. ERECTA receptor-like kinase and heterotrimeric $\mathrm{G}$ protein from Arabidopsis are required for resistance to the necrotrophic fungus Plectosphaerella cucumerina. Plant Journal 43, 165-180.

Luna E., Pastor V., Robert J., Flors V., Mauch-Mani B., Ton J., 2011. Callose Deposition: A Multifaceted Plant defence Response. Mol. Plant-Microbe Interact. 24, 183-193.

Mauch-Mani, B., Mauch, F., 2005. The role of abscisic acid in plant-pathogen interactions. 
Curr. Opin. Plant Biol. 8, 409-414.

Mellersh D. G., Foulds I. V., Higgins V. J., Heath M. C. 2002. $\mathrm{H}_{2} \mathrm{O}_{2}$ plays different roles in determining penetration failure in three diverse plant-fungal interactions. Plant Journal 29, 257-268.

Melotto M., Underwood W., He S. Y., 2008. Role of stomata in plant innate immunity and foliar bacterial diseases. Annu. Rev. Phytopathol. 46, 101-122.

Miller G., Schlauch K., Tam R., Cortes D., Torres M. A., Shulaev V., Dangl J. L., Mittler R., 2009: The plant NADPH oxidase RBOHD mediates rapid systemic signallingin response to diverse stimuli. Sci. Signal. 2, ra45

Mittler, R., Vanderauwera, S., Suzuki, N., Miller, G., Tognetti, V.B., Vandepoele, K., Gollery, M., Shulaev, V., Van Breusegem, F., 2011. ROS signalling: the new wave?. Trends Plant Sci. 16, 300-309.

Mittler, R., Vanderauwera, S., Suzuki, N., Miller, G., Tognetti, V.B., Vandepoele, K., Gollery, M., Shulaev, V., Van Breusegem, F., 2011. ROS signalling: the new wave?. Trends Plant Sci. 16, 300-309.

Mou Z., Fan W., Dong X., 2003: Inducers of plant systemic acquired resistance regulate NPR1 function through redox changes. Cell 113, 935-944.

Mukherjee, M., Larrimore, K.E., Ahmed, N.J., Bedick, T.S., Barghouthi, N.T., Traw, M.B., Barth, C., 2010. Ascorbic Acid Deficiency in Arabidopsis Induces Constitutive Priming That is Dependent on Hydrogen Peroxide, Salicylic acid, and the NPRI gene. MPMI 23, 340-351.

Parisy V., Poinssot B., Owsianowski L., Buchala A., Glazebrook J., Mauch F., 2007. Identification of PAD2 as a gamma-glutamylcysteine synthetase highlights the importance of glutathion in disease resistance of Arabidopsis. Plant J 49, 159-172.

Pastor V., Luna E., Cerezo M., Ton J., García-Agustín P., Flors V. submitted. Fine tune of ROS homeostasis regualtes primed unmune responses in Arabidopsis.

Pastor V., Vicent C., Cerezo M., Mauch-Mani B., Dean J., Flors V., 2012. Detection, characterization and quantification of salicylic acid conjugates in plant extracts by ESI tandem mass spectrometry techniques. Plant Physiol and Biochemistry 53, 1926.

Pastori G. M., kiddle G., Antoniw J., Bernard S., Veljovic-Jovanovic S., Verrier P. J., Noctor G., Foyer C. H., 2003: Leaf vitamin C contents modulate plant defence transcripts and regulate genes that control development through hormone signalling. The Plant Cell, 15, 939-951.

Pavet, V., Quintero, C., Cecchini, N.M., Rosa, A.L., Alvarez, M.E., 2006. Arabidopsis displays centromeric DNA hypomethylation and cytological alterations of heterochromatin upon attack by Pseudomonas syringae. Mol. Plant-Microbe Interact. 19, 577-587.

Pozo, M.J., Van Der Ent, S., Van Loon, L.C., Pieterse, C.M.J., 2008. Transcription factor MYC2 is involved in priming for enhanced defence during rhizobacteria-induced systemic resistance in Arabidopsis thaliana RID A-9326-2011. New Phytol. 180, 511-523.

Prost I., Dhondt S., Rothe G., Vicente J., Rodríguez M. J., Kift N., Carbone F., Griffiths G., Esquerre-Tugaye M. T., Rosahl S., Castresana C., Hamberg M., Fournier J., 2005. Evaluation of the antimicrobial activities of plant oxylipins supports their involvement in defence against pathogens. Plan Physiology 139, 1902-1913.

Robert-Seilaniantz A., Grant M., Jones J. D. G., 2011. Hormone crosstalk in plant disease and defence: more than just JASMONATE-SALICYLATE antagonism. Annu. Rev. Phytopathol. 49, 317-343. 
Roetschi A., Si-Ammour A., Belbahri L., Mauch F., Mauch-Mani B., 200. Characterization of an Arabidopsis-Phytophthora pathosystem: resistance requires a functional PAD2 gene and is independent of salicylic acid, ethylene and jasmonic acid signalling. Plant Journal 28, 293-305.

Saeed AI, Sharov V, White J, Li J, Liang W, Bhagabati N, Braisted J, Klapa M, Currier T, Thiagarajan M, Sturn A, Snuffin M, Rezantsev A, Popov D, Ryltsov A, Kostukovich E, Borisovsky I, Liu Z, Vinsavich A, Trush V, Quackenbush J. TM4: a free, open-source system for microarray data management and analysis. Biotechniques. 2003, 34:374-378.

Sánchez-Rodríguez C., Estévez J. M., Llorente F., Hernández-Blanco C., Jordá L., Pagán M., Marco Y., Somerville S., Molina A. 2009. The ERECTA receptor-like kinase regulates cell wall-mediated resistance to pathogens in Arabidopsis thaliana. MPMI 8, 953-963.

Sánchez-Vallet A., Ramos B., Bednarek P., Lopez G., Pislewska-Bednarek M., SchulzeLefert P., Molina A., 2010. Tryptophan-derived secondary metabolites in Arabidospis thaliana confer non-host resistance to necrotrophic Plectosphaerella cucumerina fungi. Plant Journal 63, 115-127.

Schalaeppi K., Bodenhausen N., Buchala A., Mauch F., Reymond P., 2008. The glutathionedeficient mutant pad2-1 accumulates lower amounts of glucosinolates and is more susceptible to the insect herbivore Spodoptera litoralis. Plant J 55, 774-786.

Sellam A., Iacomi-Vasilescu B., Hudhomme P., Simoneau P., 2007. In vitro antigungal activity of brassinin, camalexin and two isothiocyanates against the crucifer pathogens Alternaria brassicicola and Alternaria brassicae. Plant Pathology 56, 296-301.

Spadaro D., Yun B-W., Spoel S. H., Chu C., Wang Y-Q., Loake G. J., 2010. The redox switch: dynamic regulation of protein function by cysteine modifications. Physiologia Plantarum 138, 360-371.

Smith C.A., Want E.J., Tong G.C., Abagyan R., Siuzdak G. 2006. XCMS: Processing Mass Spectrometry Data for Metabolite Profiling Using Nonlinear Peak Alignment, Matching, and Identification. Analytical Chemistry 78 (3), 779-787

Suza W. P., Avila C. A., Carruthers K., Kulkarni S., Goggin F. L., Lorence A., 2010. Exploring the impact of wounding and jasmonates on ascorbate metabolism. Plant Physiology and Biochemistry 48, 337-350.

Tada Y., Spoel S. H., Pajerowska-Mukhtar K., Mou Z., Song J., Wang C., Zuo J., Dong X., 2008. Plant immunity requires conformational charges of NPR1 via S-nitrosylation and thioredoxins. Science 321, 952-956.

Ton J., Mauch-Mani B., 2004. Beta-amino-butyric acid-induced resistance against necrotrophic pathogens is based on ABA-dependent priming for callose. Plant $\mathrm{J} 38$ : 119-130.

Ton, J., Flors, V., Mauch-Mani, B., 2009. The multifaceted role of ABA in disease resistance. Trends Plant Sci. 14, 310-317.

Vernoux T., Wilson R. C., Seeley K. A., Reichheld J. P., Muroy S., Brown S., Maughan S. C., Cobbett C. S., Van Montagu M., Inzé D., May M. J., Sung A. R., 2000. The ROOT MERISTEMLESS1/CADMIUM SENSITIVE2 gene defines a glutathionedependent pathway involved in initiation and maintenance of cell division during postembryonic root development. Plant Cell 12, 97-110.

Vicedo, B., Flors, V., de la O Leyva, M., Finiti, I., Kravchuck, Z., Real, M.D., GarcíaAgustín, P., González-Bosch, C., 2009. Hexanoic acid-induced resistance against Botrytis cinerea in tomato plants. MPMI 22, 1455-1465. 
Wheeler G. L., Jones M. A., Smirnoff N., 1998. The biosynthetic pathway of vitamin C in higher plants. Nature 393, 365-369.

Xing, Y., Jia, W., and Zhang, J. 2008. AtMKK1 mediates ABA-induced CAT1 expression and $\mathrm{H}_{2} \mathrm{O}_{2}$ production via AtMPK6-coupled signallingin Arabidopsis. Plant J. 54:440-451.

Zhang, J., Shao, F., Li, Y., Cui, H., Chen, L., Li, H., Zou, Y., Long, C., Lan, L., Chai, J., Chen, S., Tang, X., and Zhou, J. M. 2007. A Pseudomonas syringae effector inactivates MAPKs to suppress PAMP-induced immunity in plants. Cell Host Microbe 1:175-85.

\section{Supplementary material}

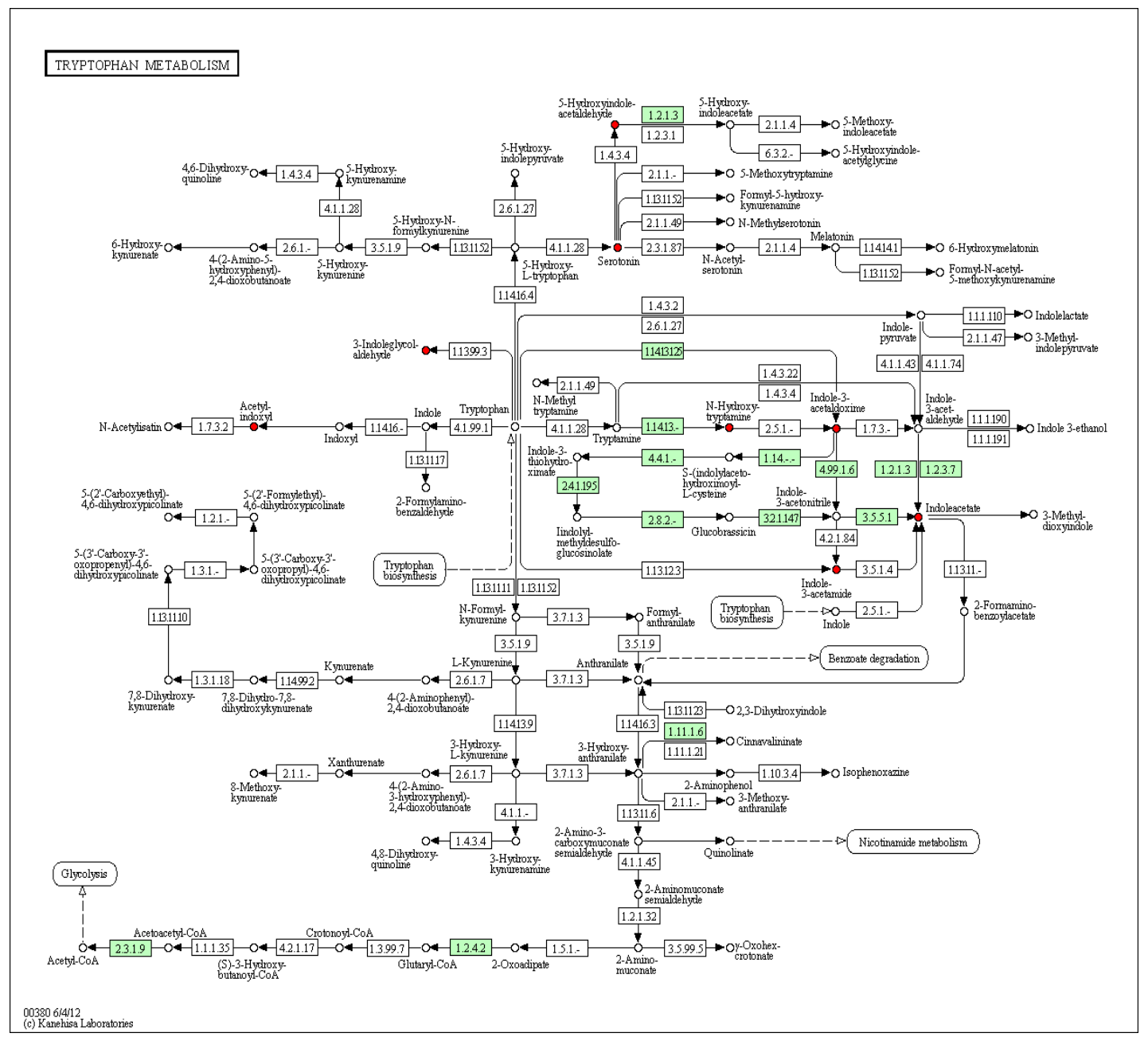

Figure S1: Tryptophan metabolic pathway. Source KEGG (http://www.genome.jp/kegg/pathway.html). 


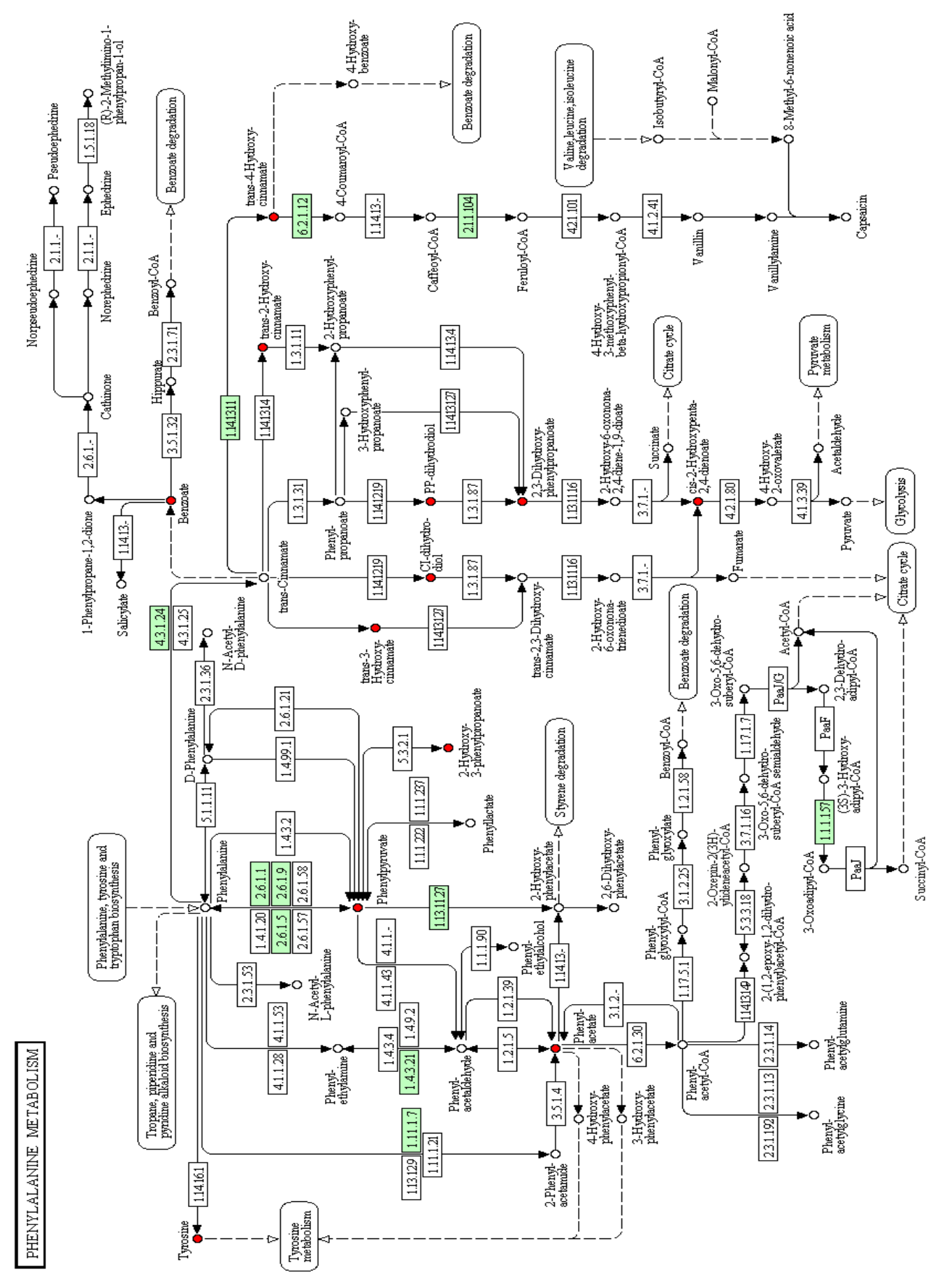

Figure S2: Biosynthesis of phenylalanine: source KEGG. (http://www.genome.jp/kegg/pathway.html). 


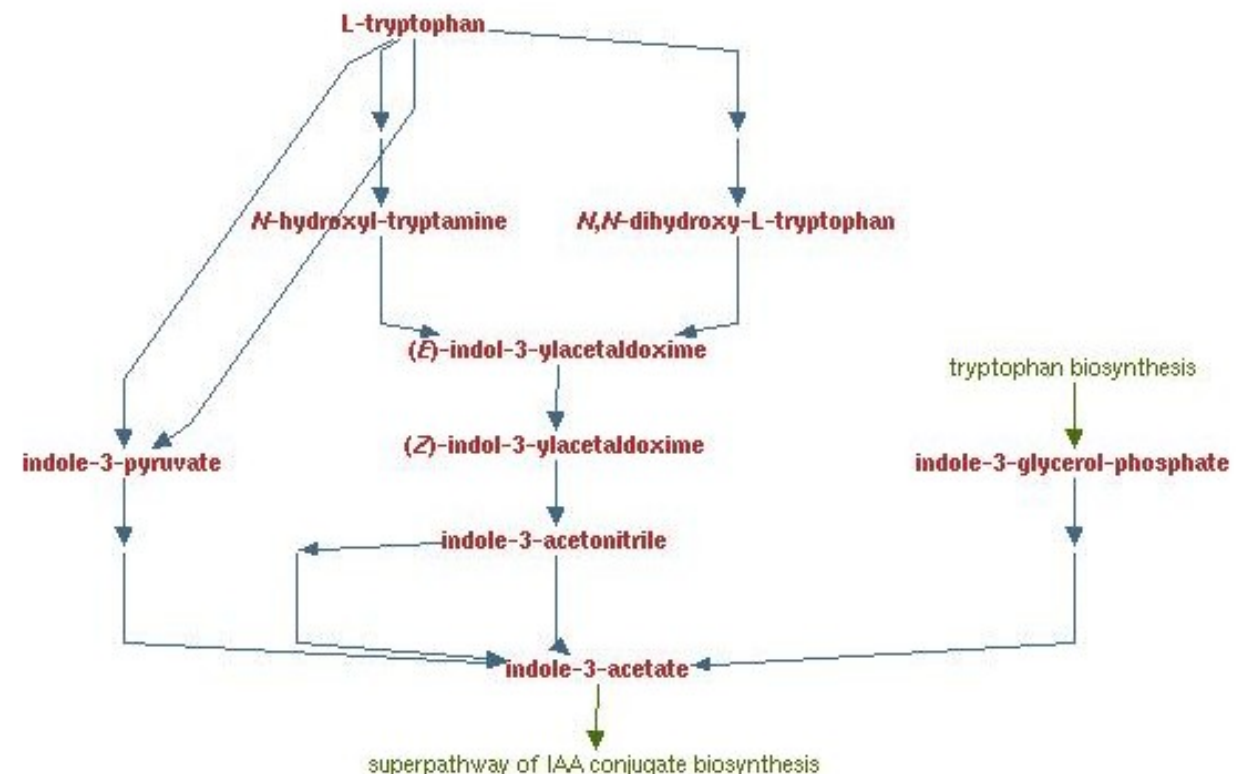

Figure S3. Indolacetic acid biosynthesis. Source AraCyc. (www.plantcyc.org). 


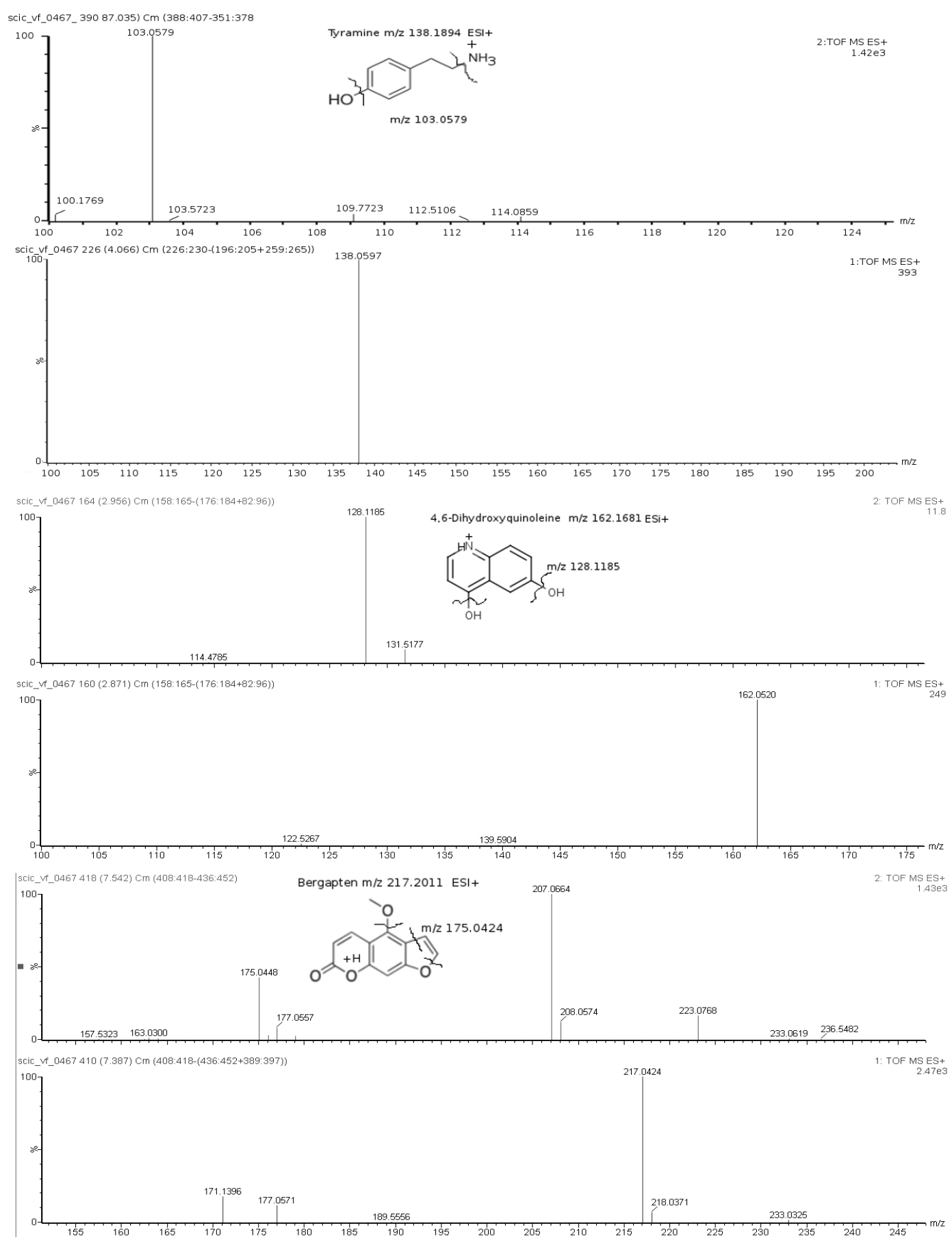

Figure S4. Demosntrative confirmation spectra of representative compounds obtained in positive ESI mode. Primed signals obtained in the heat-map analysis were combined in the F1 using the exact mass. The retention time information of the F1 selected peaks was combined in the F2. Parent ion and fragmentation spectra of thiramine, 4,6-dihydroquinoleine and bergaptene are shown with its respective fragmentation maps. 
Table S5: List of primers used for RT-qPCR.

\begin{tabular}{|c|c|}
\hline PR1 fw & GTCTCCGCCGTGAACATGT \\
\hline PR1 rev & CGTGTTCGCAGCGTAGTTGT \\
\hline PDF1.2 fw & CGAGAAGCCAAGTGGGACAT \\
\hline PDF1.2 rev & TCCATGTTTGGCTCCTTCAA \\
\hline VSP2 fw & AATGTCACTCTCGACAATCTCGAA \\
\hline VSP2 rev & GGCTTCAATATGAGATGCTTCCA \\
\hline$R A B 18 f w$ & CGGGACTGAAGGCTTTGGA \\
\hline RAB18 rev & CACCACTTTCCTTGTGGAGTTG \\
\hline$M Y C 2 f w$ & AACCCGAGACGGAGATCGA \\
\hline MYC2 rev & TCCTGATCCGCCGGAGTA \\
\hline Atlg13320 fw & TAACGTGGGCAAAATGATG \\
\hline At $\lg 13320 \mathrm{rev}$ & GTTCTCCACAACCGCTTGGT \\
\hline GAPDH3 fw & TTGGTGACAACAGGTCAAGCA \\
\hline GAPDH $3 \mathrm{rev}$ & AAACTTGTCGCTCAATGCAATC \\
\hline
\end{tabular}




\section{Concluding remarks}

The effect of PAMPs on the induction callose in Arabdopsis variates according to environmental changes of the experiment. Furthermore, ABA-mediated callose deposition it's enormously modified by the addition to the Ms media of sucrose, vitamins and the light intensity.

The $\mathrm{H}_{2} \mathrm{O}_{2}$ accumulation is an event that happens previously to callose deposition induced by chitosan. In addition, there is a co-localization of both responses in the plant tissues. This results are only observed upon chitosan challenge, since after Flg22 treatment, the $\mathrm{H}_{2} \mathrm{O}_{2}$ accumulation is transitory and not sustained in time, despite it is rapidly accumulated after 30 ' of the treatment.

The callose triggered by Flg22 depends of a functional PEN2-2 (glucosinolate pathway), RBOHD, VTC1 and PMR4, while the callose triggered by chitosan follows different mechanisms. This demonstrates a different regulation of plant defences depending on the PAMP/pathogen that attacks the plant (a fungus or a bacterium).

The non protein amino-acid BABA primes $\mathrm{H}_{2} \mathrm{O}_{2}$ and callose accumulation in response to chitosan challenge but not to Flg22.

The callose and $\mathrm{H}_{2} \mathrm{O}_{2}$ seems to be a generic priming mechanism against chitosan, since mutants that express constitutive priming show a similar phenotype to BABA-treated plants.

The BABA-IR against P. cucumerina is based on $\mathrm{H}_{2} \mathrm{O}_{2}$ priming that coordinate a fast callose deposition at the penetration sites. Basal defence mechanisms and primed defences against $P$. cucumerina follow different signalling pathways, despite they share some common responses.

Callose and $\mathrm{H}_{2} \mathrm{O}_{2}$ priming is related to a resistance phenotype against $P$. cucumerina. This $\mathrm{H}_{2} \mathrm{O}_{2}$ enhancement generates an oxidized cellular status that correlates with lower rates of $\mathrm{GSH} / \mathrm{GSSG}$ in infected BABA-treated plants respect to infected controls.

Priming against P. cucumerina or PAMP treatment induces and increase of $R B O H D$ transcripts that may rend more $\mathrm{H}_{2} \mathrm{O}_{2}$ upon challenge. At the same time, it is also observed an increase of GSHI and $V T C l$ which may help the plant to always keep the peroxide levels at high rates but under control to avoid cellular damage. According to our results $C A T 2$ does not play a role in priming mechanisms.

BABA-IR against P. cucumerina needs an intact function of RBOHD and GSH1. This last gene is, in addition, a key element in basal resistance against the necrotroph.

BABA-IR against $P$. cucumerina is mediated by a ROS equilibrium, callose and ABA, while OPDA, JA and SA seem not to play an essential role in priming mechanisms. Despite, they are induced in wile type plants upon BABA treatment, with the exception of 
ABA signalling, the impairment in SA and JA-regulated defence responses, do not block BABA-IR.

In mutants impaired in early defence priming, since these are dispensable mechanisms, it can be observed a priming of secondary layers activated by BABA. This happens in $v t c 1$ that shows camalexin priming upon P. cucumerina challenge while it fails to display priming of peroxide and callose. Indeed, this demonstrates priming is a nonunique horizontal multicomponent phenomenon. 


\section{Conclusiones}

El efecto de los PAMPs sobre al inducción de calosa en plántulas de Arabidopsis varía con las condiciones ambientales del cultivo. Además la regulación de calosa inducida por PAMPs mediada por el ácido abscísico se ve enormemente modificada por la adición de sacarosa y vitaminas en el medio de cultivo, así como por la intensidad de luz.

La acumulación de peróxido es un evento previo a la deposición de callosa inducida por chitosan. Además existe una colocalización de ambas respuestas en los tejidos de la planta. Esta colocalización de calosa y $\mathrm{H}_{2} \mathrm{O}_{2}$ sólo ocurre tras los tratamientos con chitosan, ya que el acúmulo de $\mathrm{H}_{2} \mathrm{O}_{2}$ frente a Flg22 es transitorio y no se mantiene en el tiempo, a pesar de su rápida acumulación a los 30' tras el tratamiento.

La calosa inducida por Flg22 es dependiente de PEN2-2 (glucosinolatos), RBOHD, VTC1 y PMR4, mientras que la acumulada por chitosan está regulada por otros mecanismos distintos, demostrando la diferente regulación de defensas dependiendo del tipo de patógeno (hongo o bacteria).

El aminoácido no proteico BABA estimula el priming en la acumulación $\mathrm{H}_{2} \mathrm{O}_{2}$ y calosa en respuesta a los tratamientos con chitosan pero no frente a Flg22.

La inducción de calosa y $\mathrm{H}_{2} \mathrm{O}_{2}$ es un mecanismo genérico de priming, ya que mutantes reconocidos de que expresan priming constitutivo presentan un fenotipo similar a los controles tratados con BABA.

La resistencia inducida por BABA frente a $P$. cucumerina se basa en la inducción de peróxido de hidrógeno, que coordinadamente activa una rápida deposición de calosa frente al patógeno. Los mecanismos basales y los inducidos por priming, aunque pueden compartir señales comunes, son distintos.

El priming de calosa y $\mathrm{H}_{2} \mathrm{O}_{2}$ frente a $P$. cucumerina se correlaciona con un fenotipo de resistencia inducida. Este aumento de $\mathrm{H}_{2} \mathrm{O}_{2}$ da lugar a un ambiente celular más oxidado, dando menores valores de GSH/GSSG en las plantas infectadas y tratadas con BABA que en las infectadas control.

El mecanismo de priming induce $R B O H D$ a nivel transcripcional, pudiendo preparar a la planta para producir mayores niveles de $\mathrm{H}_{2} \mathrm{O}_{2}$ una vez es atacada por un patógeno o estimulada con un PAMP. Al mismo tiempo, se acumulan transcritos de GSH1 y VTC1 permitiendo a la planta mantener los niveles de $\mathrm{H}_{2} \mathrm{O}_{2}$ bajo control, para evitar daños celulares. CAT2 no interviene en los mecanismos de priming.

La resistencia inducida frente a $P$. cucumerina necesita la función de $R B O H D$ y GSH1 intactas, siendo este último gen necesario también para la resistencia basal contra este necrótrofo.

La defensa inducida por BABA frente a $P$. cucumerina es dependiente de callose y ABA, mientras que OPDA, JA y SA, si bien se ven estimulados por la infección, no parecen 
jugar un papel tan importante en los mecanismos de priming.

A excepción de la señalización por $\mathrm{ABA}$, el bloqueo de las rutas de señalización reguladas por SA y JA no modifican la resistencia inducida por BABA.

Cuando los mecanismos primarios susceptibles de ser inducidos durante el priming están bloqueados, si éstos resultan dispensables para la resistencia inducida, aún se pueden activar otras líneas tardías de defensa, que permiten expresar priming por BABA. El priming de camalexina puede explicar el fenotipo de resistencia en vtcl aún cuando la inducción de calosa y $\mathrm{H}_{2} \mathrm{O}_{2}$ esté bloqueada. Esto demuestra que el fenómeno de priming es horizontal y multicomponente. 


\section{Publications and communications related to the present work:}

\section{Research papers:}

Pastor V., Luna E. (both authors, equal contribution), Mauch-Mani B., Ton J., Flors V., "Primed plants do not forget". Environ. Exp. Bot., doi:10.1016/j.envexpbot.2012.02.013.

Luna E., Pastor V. (both authors, equal contribution), Robert J., Flors V., MauchMani B., Ton J., 2011. "Callose deposition: a multifaceted plant defence response" Mol. Plant Microbe Interact., 24,183-93.

Pastor V., Luna E., Cerezo M., Ton J., García-Agustín P., Flors V., (submitted). "Fine tuning of ROS homeostasis regulates primed immune responses in Arabidopsis".

\section{Posters:}

Pastor V., Luna E., Ton J, García-Agustín P, Cerezo M, Flors V: "Hydrogen peroxide mediates callose priming induced by BABA upon chitosan treatment." XIX Reunión de la Sociedad Española de Fisiología Vegetal. XII Congreso Hispano Luso. (Castellón, 21-24 junio 2011).

Pastor V, Luna E, Ton J, García-Agustín P, Cerezo M, Flors V: "A specific homeostasis between callose and $\mathrm{H}_{2} \mathrm{O}_{2}$ is needed for an intact BABA-IR against $P$. cucumerina." PR-Proteins and Induced Resistance Against Pathogens and Insects (Neûchatel-Switzerland, 4-8 septiembre 2011).

Pastor V., Luna E., Ton J., Cerezo M., García-Agustín P., Flors V., : "More oxidized environment is needed to develop primed responses against Plectosphaerella cucumerina" Society for Experimental Botany Annual Meeting (Salzburg 29 junio-2 julio 2012).

\section{Oral presentations:}

"Oxidative metabolism in priming". Victoria Pastor, Pilar García-Agustín, Victor Flors.

"Controversial roles of $\mathrm{ABA}$ in plant resistance against pathogens". Victoria Pastor, Estrella Luna, Jurriaan Ton, Brigitte Mauch-Mani, Jerôme Robert, Cristian Vicent, Victor Flors. Meeting of Spanish Network of Plant-Pathogen Interaction. Cercedilla (Spain) 9-11 June (2010).

"ROS tuning and hormonal conjugation: members of the horizontal phenomenon of priming". Victoria Pastor, Jordi Gamir, Miguel Cerezo, Victor Flors. Society for Experimental Biology, Salzburg (Austria) 28 June-2 July 2012.

\section{Proceedings:}

Pastor V., Luna E., Ton J., García-Agustín P., Cerezo M., Flors V., 2011. “A specific homeostasis between callose and $\mathrm{H}_{2} \mathrm{O}_{2}$ is needed for an intact BABA-IR against $P$ cucumerina". IOBC Working Group (in press) 
